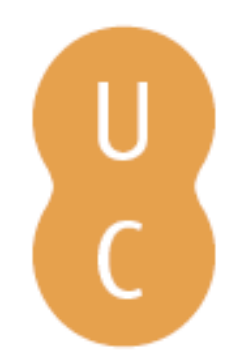

\title{
pommalina
}

\section{Conselhos de empresa europeus: um estudo dos setores metalúrgico, químico e financeiro em Portugal}

Autor(es): $\quad$ Costa, Hermes Augusto; Costa, Paula Reis

Publicado por: Imprensa da Universidade de Coimbra

URL

persistente: URI:http://hdl.handle.net/10316.2/32220

DOI: $\quad$ DOI:http://dx.doi.org/10.14195/978-989-26-0632-3

Accessed : $\quad$ 19-May-2017 18:04:41

A navegação consulta e descarregamento dos títulos inseridos nas Bibliotecas Digitais UC Digitalis, UC Pombalina e UC Impactum, pressupõem a aceitação plena e sem reservas dos Termos e Condições de Uso destas Bibliotecas Digitais, disponíveis em https://digitalis.uc.pt/pt-pt/termos.

Conforme exposto nos referidos Termos e Condições de Uso, o descarregamento de títulos de acesso restrito requer uma licença válida de autorização devendo o utilizador aceder ao(s) documento(s) a partir de um endereço de IP da instituição detentora da supramencionada licença.

Ao utilizador é apenas permitido o descarregamento para uso pessoal, pelo que o emprego do(s) título(s) descarregado(s) para outro fim, designadamente comercial, carece de autorização do respetivo autor ou editor da obra.

Na medida em que todas as obras da UC Digitalis se encontram protegidas pelo Código do Direito de Autor e Direitos Conexos e demais legislação aplicável, toda a cópia, parcial ou total, deste documento, nos casos em que é legalmente admitida, deverá conter ou fazer-se acompanhar por este aviso.

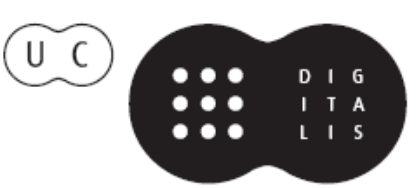




\section{CONSELHOS DE EMPRESA EUROPEUS}

UM ESTUDO DOS SETORES METALÚRGICO, QUÍMICO E FINANCEIRO EM PORTUGAL

HERMES AUGUSTO COSTA PAULA REIS COSTA

IMPRENSA DA UNIVERSIDADE DE COIMBRA COIMBRA UNIVERSITY PRESS 
(Página deixada propositadamente em branco) 
焉

$\frac{\mathrm{I}}{\mathrm{U}}$ 


\section{EDIĈ̃o}

Imprensa da Universidade de Coimbra

Email: imprensa@uc.pt

URL: http//www.uc.pt/imprensa_uc

Vendas online: http://livrariadaimprensa.uc.pt

\section{CoORdenaç̃̃o Editorial}

Imprensa da Universidade de Coimbra

\section{ConceÇ̃̃o Gráfica}

António Barros

\section{INFOGRAFIA DA CAPA}

Carlos Costa

Pré-impressão

Alda Teixeira

EXECUÇão GráficA

www.artipol.net

\section{ISBN}

978-989-26-0631-6

\section{ISBN DIGITAL}

978-989-26-0632-3

DOI

http://dx.doi.org/10.14195/978-989-26-0632-3

DEPósito LEgAL

$375558 / 14$

Obra Publicada com o apoio de:

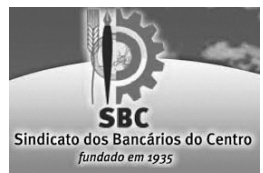

(C) MaIo 2014, Imprensa da Universidade de Coimbra 


\section{CONSELHOS \\ DE EMPRESA \\ EUROPEUS}

UM ESTUDO DOS SETORES

METALÚRGICO, QUÍMICO

E FINANCEIRO EM PORTUGAL

HERMES AUGUSTO COSTA

PAULA REIS COSTA

IMPRENSA DA

UNIVERSIDADE

DE COIMBRA

COIMBRA

UNIVERSITY

PRESS 
(Página deixada propositadamente em branco) 
Para o Simão e o Dinis 
(Página deixada propositadamente em branco) 


\section{Í N D I C E}

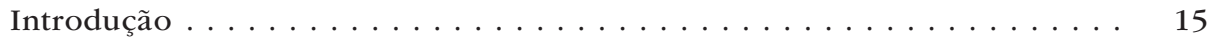

\section{CAPÍTULO 1}

\section{A necessária regulação social das multinacionais}

e o papel dos Conselhos de Empresa Europeus

1. Multinacionais e formas de participação laboral . . . . . . . . . . 24

1.1. Das ações voluntaristas.................... 24

1.2. ...à necessária normatividade laboral. . . . . . . . . . . . 27

2. Antecedentes da Diretiva $94 / 45 /$ CE . . . . . . . . . . . . . . 30

3. Objetivos e revisão da Diretiva dos Conselhos de Empresa Europeus 33

3.1. Missão e objetivos da Diretiva 94/45/CE . . . . . . . . . . 34

3.2. Principais razões para rever a Diretiva . . . . . . . . . . . . 37

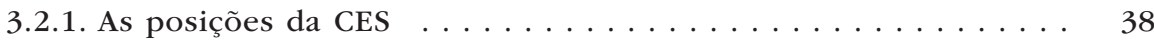

3.2.2. As visões dos representantes de trabalhadores em CEEs . . . . . 40

3.2.3. A aproximação de posições entre parceiros sociais europeus . . 46

3.3. O que é neo na Diretiva 2009/38/CE? . . . . . . . . . . . . . . 48

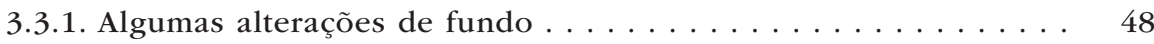

3.3.2. O timing da informação e consulta e a relação nacional/ transnacional. .......................... 51

3.3.3. Em busca de CEEs enquanto "atores europeus" .......... 56

\section{CAPÍTULO 2}

Estudos, tipologias e "boas práticas" sobre Conselhos de Empresa Europeus

1. Estudos e temas de investigação sobre os CEEs. . . . . . . . . . . 65

1.1. CEEs e níveis de análise .................. 66 
1.2. Modus operandi dos CEEs: "vida interna", casos específicos

e fatores estruturais . . . . . . . . . . . . . . . . . . 70

1.3. Os CEEs numa perspetiva organizacional (não lucrativa) . . . . . 72

1.4. Em busca de uma identidade laboral transnacional . . . . . . . . 75

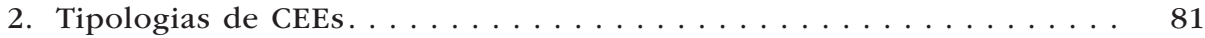

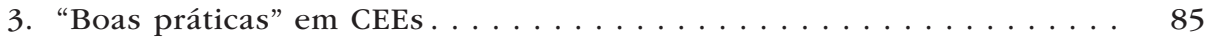

3.1. Práticas generalizadas dos CEEs . . . . . . . . . . . . 86

3.2. Formas de relacionamento entre atores . . . . . . . . . . . 90

3.3. A questão da comunicação e o papel das novas TIC . . . . . . . . . 91

3.4. A questão da formação...................... 94

3.5. Processos de reestruturação empresarial . . . . . . . . . . . . 96

3.6. Temas "além" da Diretiva dos CEEs . . . . . . . . . . . . . . . . . 102

\section{CAPÍTULO 3}

Análise setorial da constituição de Conselhos de Empresa Europeus em Portugal, nos setores metalúrgico, químico e financeiro

1. Multinacionais abrangidas pela Diretiva dos CEEs e países de sede das multinacionais, segundo os setores metalúrgico, químico e financeiro........................... 113

2. Multinacionais e Conselhos de Empresa Europeus, por setor de atividade........................ 116

3. Países da sede das multinacionais com operações em Portugal, por setor de atividade

\section{CAPÍTULO 4}

Acordos de Conselhos de Empresa Europeus envolvendo representantes portugueses em multinacionais dos setores metalúrgico, químico e financeiro

1. Acordos em vigor e data da assinatura. . . . . . . . . . . . 130

2. Natureza $\operatorname{dos}$ acordos . . . . . . . . . . . . . . . . . 134

2.1. Tipo de acordo . . . . . . . . . . . . . . . 134

2.2. Signatários dos acordos: representantes dos trabalhadores . . . . 138

2.3. Legislação nacional aplicável . . . . . . . . . . . . . . . . . 140

2.4. Alcance geográfico . . . . . . . . . . . . . . . . . . 141

2.5. Duração . . . . . . . . . . . . . . . . . . . 144 
3. Composição, objetivos e competências dos acordos . . . . . . . . . 144

3.1. Composição. . . . . . . . . . . . . . . . . . . . . . 144

3.2. Objetivos gerais . . . . . . . . . . . . . . . . 148

3.3. Competências . . . . . . . . . . . . . . . . 148

3.3.1. Informação e consulta . . . . . . . . . . . . . . . . . . . . 149

3.3.2. Oportunidade da informação e consulta . . . . . . . . . . . . 154

3.3.3. Questões expressamente excluídas dos acordos. . . . . . . . . 155

3.3.4. Confidencialidade . . . . . . . . . . . . . . . . 156

4. Representantes e seleção dos representantes dos trabalhadores. . . . . 158

4.1. Os critérios de atribuição dos lugares . . . . . . . . . . . 158

4.2. Requisitos para ser eleito/nomeado representante . . . . . . . . . 159

4.3. Duração dos mandatos . . . . . . . . . . . . . . . . . . 161

4.4. Formação dos representantes . . . . . . . . . . . . . . . 161

4.5. Proteção aos representantes . . . . . . . . . . . . . . . 163

5. Reuniões dos Conselhos de Empresa Europeus. . . . . . . . . . . . . . . 163

5.1. Reuniões ordinárias, preparatórias, posteriores e extraordinárias 163

5.2. Língua franca, tradução de documentos e interpretação simultânea 164

5.3. Peritos. . . . . . . . . . . . . . . . . . . . 168

\section{CAPÍTULO 5 \\ Os olhares dos protagonistas: \\ representantes de trabalhadores e administrações}

1. A expressão dos representantes portugueses em CEEs . . . . . . . . . . 171

2. A visão dos representantes de trabalhadores . . . . . . . . . . . . . . . 173

2.1. A instituição e funcionamento dos CEEs em Portugal . . . . . . . . . 175

2.1.1. A instituição dos CEEs . . . . . . . . . . . . . . . . . . . 175

2.1.2. O funcionamento dos CEEs . . . . . . . . . . . . . . . 180

2.2. CEEs nos setores metalúrgico, químico e financeiro: as Federações

Sindicais Europeias e os estudos de caso (Volkswagen, Air Liquide, BES) . . . . . . . . . . . . . . . . . . . . 188

2.2.1. O papel das Federações Sindicais Europeias . . . . . . . . . . . . 189

2.2.2. O CEE do Grupo VW . . . . . . . . . . . . . . . . . . . . . 195

2.2.2.1. Uma cultura de parceria social como ponto de partida . . . . . 196

2.2.2.2. O Grupo VW, a Autoeuropa e o papel de interlocução da CT 197

2.2.2.3. Um CEE sintonizado com a ideia de democracia laboral . . . . 203

2.2.2.4. Um CEE cuja prática vai além do acordo formal . . . . . . . . 214

2.2.2.5. Um CEE pragmático e participativo . . . . . . . . . . . . 222 
2.2.3. O CEE do Grupo Air Liquide . . . . . . . . . . . . . . . 224

2.2.3.1. Objetivos e áreas de intervenção do Grupo Air Liquide. . . . . 225

2.2.3.2. Nascimento e funcionamento do CEE . . . . . . . . . . . . 228

2.2.3.3. Um acordo em segundo plano face à "prática" . . . . . . . . . . . 229

2.2.3.4. O papel (negocial) da comissão de trabalhadores . . . . . . . 233

2.2.3.5. Um CEE imune à crise internacional? . . . . . . . . . . . . . . 236

2.2.3.6. Conquistas do CEE . . . . . . . . . . . . . . . . . . . 239

2.2.4. O CEE do Grupo BES . . . . . . . . . . . . . . . . . 244

2.2.4.1. Um CEE pioneiro em Portugal . . . . . . . . . . . . . . . . 244

2.2.4.1.1. As condições para o surgimento do CEE . . . . . . . . . 245

2.2.4.1.2. O dinamismo do CEE . . . . . . . . . . . . . . . . . . 249

2.2.4.1.3. Resultados alcançados . . . . . . . . . . . . 250

2.2.4.2. O CEE no presente: uma legalização que confirma uma prática 251

2.2.4.2.1. Legalizar para reforçar a legitimidade do CEE . . . . . . . . . 251

2.2.4.2.2. O processo de revisão da Diretiva. . . . . . . . . . . . . 253

2.2.4.2.3. A relação entre atores e o papel "guia" dos sindicatos . . . . 254

2.2.4.2.4. Um "modus operandi" assente na busca de respostas . . . . . 256

3. A visão das entidades patronais . . . . . . . . . . . . . . . . . . . 261

3.1. Os CEEs entre um criticismo convicto e um otimismo defensivo? 261

3.2. Ilações do caso português: permissividade, mas com indiferença 268

Conclusão. . . . . . . . . . . . . . . . . . . . . . . 273

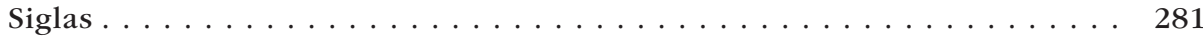

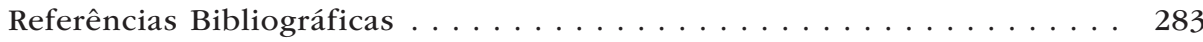




\section{ÍNDICE DE QUADROS E GRÁFICOS}

\section{Quadros}

Quadro 1: Multinacionais, por setor de atividade. . . . . . . . . . . . 113

Quadro 2: Países de sede das multinacionais, por setor de atividade . . . 115

Quadro 3: Estatuto do CEE, por setor de atividade das Multinacionais . . . 117

Quadro 4: Estatuto do CEE, por setor de atividade das Multinacionais (\%) 117

Quadro 5: Multinacionais com operações em Portugal, por setor de atividade......................... 121

Quadro 6: Países de sede das multinacionais com operações em Portugal, por setor de atividade. . . . . . . . . . . . . . . . . . . 122

Quadro 7: Estatuto do CEE, nas multinacionais com operações em Portugal, por setor de atividade. . . . . . . . . . . . . . . 123

Quadro 8: Multinacionais, por presença em Portugal, setores, CEE e existência de representante português . . . . . . . . . . . . . . 130

Quadro 9: Acordos em vigor, por país de sede das multinacionais . . . . . 131

Quadro 10: Acordos em vigor, por setor de atividade . . . . . . . . . . 133

Quadro 11: Acordos em Vigor . . . . . . . . . . . . . . . . . . 134

Quadro 12: Tipo de Acordo . . . . . . . . . . . . . . . . . . 136

Quadro 13: Tipo de acordo por setor de atividade . . . . . . . . . . . 138

Quadro 14: Signatários dos acordos por parte dos trabalhadores . . . . . . 139

Quadro 15: Legislação aplicável . . . . . . . . . . . . . . . . . . 140

Quadro 16: Legislação nacional aplicável . . . . . . . . . . . . . . . . . 141

Quadro 17: Legislação aplicável, igual ou diferente à do país de origem, por país, no e fora do EEE . . . . . . . . . . . . . . . . . 142

Quadro 18: Alcance geográfico dos acordos (sucursais abrangidas) . . . . 142

Quadro 19: Período de duração dos acordos . . . . . . . . . . . . . . 144

Quadro 20: Composição do CEE. . . . . . . . . . . . . . . . . . 146

Quadro 21: Composição dos CEEs por setores de atividade . . . . . . . . . 147

Quadro 22: Tipologia das questões objeto de informação e consulta . . . 150 
Quadro 23: Acordos restritos e acordos abrangentes . . . . . . . . . . 151

Quadro 24: Acordos abrangentes, por número de questões incluídas . . . 151

Quadro 25: Acordos restritos e abrangentes, por tipo de acordo . . . . . . 154

Quadro 26: Menção à oportunidade da informação e consulta . . . . . . . . 154

Quadro 27: Questões expressamente excluídas . . . . . . . . . . . 155

Quadro 28: Confidencialidade . . . . . . . . . . . . . . . . 157

Quadro 29: Requisitos para a eleição/nomeação dos representantes . . . . 160

Quadro 30: Formação dos representantes dos trabalhadores . . . . . . . . . 162

Quadro 31: Frequência das reuniões ordinárias dos CEEs . . . . . . . . 163

Quadro 32: Reuniões preparatórias e posteriores . . . . . . . . . . . . 164

Quadro 33: Língua de referência . . . . . . . . . . . . . . . . 165

Quadro 34: Língua de referência por país de sede da multinacional . . . . 165

Quadro 35: Interpretação/tradução . . . . . . . . . . . . . . . . . . . 167

Quadro 36: Peritos ... . . . . . . . . . . . . . . . . . . . . . 169

Quadro 37: Representantes portugueses por país de sede

das multinacionais . . . . . . . . . . . . . . . . . 172

Quadro 38: Representantes portugueses, por setor de atividade . . . . . . 173

Quadro 39: Acordo original do Conselho de Empresa Europeu do Grupo Volkswagen. . . . . . . . . . . . . . . . . . . . . . 215

Quadro 40: Acordo original do Conselho de Empresa Europeu do Grupo Air Liquide . . . . . . . . . . . . . . . . . . . 230

Quadro 41: Acordos originais do Procedimento de Informação e Consulta e do Conselho de Empresa Europeu do Grupo Banco Espírito Santo. . . 247

\section{Gráficos}

Gráfico 1: Multinacionais, por setor de atividade. . . . . . . . . . 114

Gráfico 2: Setores de Atividade das Multinacionais, por estatuto do CEE 118

Gráfico 3: Países de sede das multinacionais, por estatuto do CEE, para o

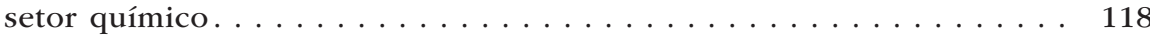

Gráfico 4: Países de sede das multinacionais, por estatuto do CEE, para o setor metalúrgico . . . . . . . . . . . . . . . . . . . . . . . 119

Gráfico 5: Países de sede das multinacionais, por estatuto do CEE, para o

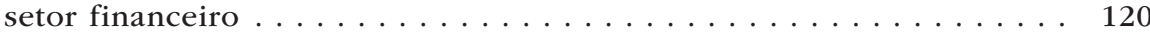

Gráfico 6: Multinacionais com operações em Portugal, por setor de actividade .......................

Gráfico 7: Setores de Atividade das Multinacionais com operações em Portugal, por estatuto do CEE . . . . . . . . . . . .

Gráfico 8: Países de sede das multinacionais com operações em Portugal, por estatuto do CEE, para o setor químico . . . . . . . . . . . 124 
Gráfico 9: Países de sede das multinacionais com operações em Portugal,

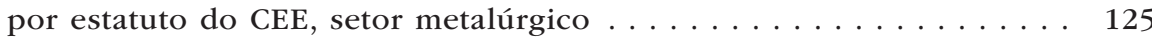

Gráfico 10: Países de sede das multinacionais com operações em Portugal, por estatuto do CEE, para o setor financeiro . . . . . . . . . . . 125

Gráfico 11: Multinacionais, por setores, presença em Portugal, com CEE e existência de representante português . . . . . . . . . . . . . 130

Gráfico 12: Acordos em vigor, por país de sede das multinacionais . . . . 132

Gráfico 13: Acordos em vigor, por setor de actividade . . . . . . . . . 133

Gráfico 14: Acordos em vigor. . . . . . . . . . . . . . . . . . 135

Gráfico 15: Tipo de Acordo . . . . . . . . . . . . . . . . . . . 137

Gráfico 16: Tipo de acordo por setor de atividade (valores absolutos) . . 138

Gráfico 17: Signatários dos acordos por parte dos trabalhadores . . . . . . 139

Gráfico 18: Legislação aplicável, igual ou diferente à do país de origem, por país, no e fora do EEE . . . . . . . . . . . . . . . 143

Gráfico 19: Alcance geográfico dos acordos (sucursais abrangidas) . . . . 143

Gráfico 20: Período de duração dos acordos . . . . . . . . . . . . . . . 145

Gráfico 21: Composição do CEE . . . . . . . . . . . . . . . . . . 146

Gráfico 22: Composição dos CEEs por países da sede das multinacionais (valores absolutos) . . . . . . . . . . . . . . . . . . . . 147

Gráfico 23: Composição dos CEEs por setores de atividade . . . . . . . . . 148

Gráfico 24: Acordos restritos e acordos abrangentes . . . . . . . . . . . . 151

Gráfico 25: Acordos abrangentes, por número de questões incluídas . . . 152

Gráfico 26: Acordos restritos e abrangentes, por país da sede

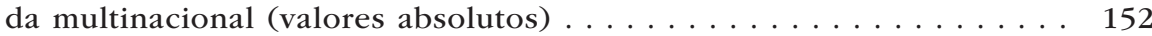

Gráfico 27: Acordos restritos e abrangentes, por setores de actividade . . 153

Gráfico 28: Confidencialidade . . . . . . . . . . . . . . . . 157

Gráfico 29: Requisitos para a eleição/nomeação dos representantes dos trabalhadores. . . . . . . . . . . . . . . . . . . 160

Gráfico 30: Formação dos representantes dos trabalhadores. . . . . . . . . 162

Gráfico 31: Língua de referência por país de sede da multinacional (valores absolutos) ...................... 166

Gráfico 32: Interpretação/tradução . . . . . . . . . . . . . . . . . . . . 167

Gráfico 33: Peritos . . . . . . . . . . . . . . . . . . . . . . . 169

Gráfico 34: Representantes portugueses por país de sede das multinacionais . . . . . . . . . . . . . . . . 173

Gráfico 35: Representantes portugueses, por setor de atividade . . . . . 174 
(Página deixada propositadamente em branco) 


\section{N T R O D U Ç Ã O}

O estudo que aqui se publica é uma versão reduzida e atualizada de um projeto de investigação sobre Conselhos de Empresa Europeus (CEEs) ${ }^{1}$. Enquadra-se num amplo conjunto de reflexões e ações sobre o papel das relações laborais na Europa e sobre as formas de participação dos trabalhadores no âmbito das multinacionais. O primeiro momento formal deste processo foi, em 1994, a Diretiva 94/45/CE - relativa à informação e consulta de trabalhadores nas empresas de dimensão comunitária -, a qual seria substituída, em 2009, pela Diretiva 2009/38/CE (em vigor desde 6 de junho de 2011). Mas a problemática dos CEEs está por consolidar não só no Espaço Económico Europeu (EEE, que inclui os Estados-membros da União Europeia, bem, como a Islândia, Noruega e o Liechtenstein), como sobretudo em Portugal.

O estudo das empresas multinacionais é, num contexto de intensificação dos processos de globalização económica, um "terreno" propício à constituição de CEEs e é tanto mais urgente de aprofundar quanto há muitas décadas são conhecidos os défices de construção de formas de identidade laboral transnacional entre trabalhadores nesse domínio da atividade das multinacionais, como no da organização laboral/sindical transnacional em geral. De resto, a ideia de um "Modelo Social Europeu" - condizente, entre outros pontos, com elevados índices de proteção

\footnotetext{
${ }^{1} \mathrm{O}$ projeto intitulou-se Informação e consulta de trabalhadores nas multinacionais: análise do impacto dos Conselhos de Empresa Europeus em Portugal nos sectores metalúrgico, químico e financeiro (proj. III/7/2008), foi financiado pelo Instituto de Investigação Interdisciplinar da Universidade de Coimbra, e os seus resultados encontram-se disponíveis em Costa e Costa (2011).
} 
social, o reconhecimento dos direitos laborais, a valorização da negociação coletiva enquanto elemento regulador das relações de trabalho, ou da maximização de serviços públicos de qualidade - fez igualmente jus a um projeto de "Europa Social", embora seja hoje cada vez mais posta em causa, em clima de crise económica mais propício à adoção de medidas de austeridade económica com evidentes implicações no plano social. Na verdade, o modelo social europeu não foi sinónimo de Europa integrada, em virtude da coexistência de uma diversidade de sistemas de relações laborais e regimes de proteção social que, consequentemente, suscitaram a identificação de cenários-tipo (igualmente diferenciados) para o futuro da Europa Social.

Mas ainda que possa ser problemático falar num sistema europeu de relações laborais, convirá recordar alguns momentos importantes que ajudaram a dar corpo à ideia de Europa Social (Costa, 2005: 249-256; Costa e Araújo, 2007c: 4-5):

- o Tratado de Roma (1957), que, lançou as bases para uma política social europeia;

- o Comité Económico e Social (1957), que acolhe os parceiros sociais tradicionais (patrões e sindicatos), bem como diversos grupos de interesses da comunidade;

- o Ato Único Europeu (1987), que consagrou o conceito de "mercado interno", acrescentando ao Tratado de Roma disposições relativas à melhoria do ambiente no meio de trabalho, ao diálogo social e à coesão económica e social;

- a Carta Comunitária dos Direitos Sociais Fundamentais dos Trabalhadores (1989), que veio consagrar, no plano comunitário, um conjunto de princípios aplicáveis à proteção dos trabalhadores e estabelecer os grandes princípios em que se baseia o modelo europeu de direito do trabalho;

- o Tratado de Maastricht (1992), que abriu caminho para um maior aprofundamento e integração da então Comunidade Europeia e que incidiu tanto na consolidação dos direitos sociais fundamentais dos trabalhadores (na forma como eles estavam expressos na Carta 
Comunitária), como no desenvolvimento de ações em domínios como a exclusão social, os deficientes, a pobreza ou a integração dos migrantes de "países terceiros";

- o Protocolo a Doze, que autorizou um Acordo a Onze sobre a Política Social e que ampliou as competências legais de intervenção no domínio da política social da UE, permitiu um maior espaço para a votação por maioria qualificada e reforçou o papel dos "parceiros sociais" europeus, reconhecendo-lhes a possibilidade de negociarem acordos coletivos europeus (de que são exemplo os acordos-quadro sobre licença parental, 1995, trabalho a tempo parcial, 1997, e contratos de duração determinada, 1999, ou ainda acordos celebrados numa base voluntária, como os relativos ao teletrabalho, 2002, ao stress associado ao trabalho, 2004, ou à perseguição e violência no trabalho, 2007);

- a Diretiva 94/45/CE que, em 1994, implementou os CEEs, destinados a instituir mecanismos de informação e consulta dos trabalhadores nas empresas ou grupos de empresas de dimensão comunitária;

- o Tratado de Amsterdão (1997), que, entre outros pontos, veio: recuperar o texto do Acordo sobre a política social do Tratado de Maastricht, integrando-o no articulado do novo tratado; definir os objetivos da UE no domínio da política social, fazendo explicitamente referência à Carta Comunitária dos Direitos Sociais Fundamentais dos Trabalhadores, de 1989; fixar as matérias sociais que carecem de aprovação por maioria qualificada; definir as condições de intervenção dos parceiros sociais nos processos de decisão da Comunidade no domínio social; incluir um "capítulo sobre o emprego", onde se reafirma que a responsabilidade primeira no domínio do emprego cabe aos Estados-membros, embora estes passem a inscrevê-la doravante no quadro de uma estratégia coordenada ao nível da Comunidade;

- a Carta dos Direitos Fundamentais da UE (no quadro da Cimeira Europeia de Nice, em dezembro de 2000), que abriu também um novo capítulo na implementação legal dos direitos sindicais nos níveis nacional e transnacional e configurou-se como um catalisador da construção de um sistema europeu de relações laborais. 
Neste estudo, a nossa atenção recai sobre uma daquelas "peças" de legislação europeia que criou condições para um reforço da informação e consulta dos trabalhadores nas empresas/grupos de empresas de dimensão comunitária - através da constituição de CEEs ou de procedimentos de informação e consulta dos trabalhadores (PICs) -, por via da acima referida Diretiva 94/45/CE, de 22.09.1994, e posteriormente pela Diretiva 2009/38/CE, de 6.05.2009. Convirá, no entanto, chamar desde já a atenção para o facto de ao longo deste livro serem ainda frequentes as referências à Diretiva 94/45/CE (a qual aparece, por vezes, também identificada com o uso da expressão "velha Diretiva"), não só porque foi esta lei comunitária que "inspirou" a principal base de dados trabalhada neste estudo, como porque a Diretiva 2009/38/CE (por vezes aqui também designada de "nova Diretiva ou "Diretiva reformulada") atravessou ela própria uma fase de transposição para os ordenamentos jurídicos dos países até 5 de junho de $2011^{2}$, só tendo entrado em vigor (como já se assinalou) em 6 de junho 2011.

As pesquisas sobre os CEEs têm merecido uma diversidade de olhares um pouco por toda a Europa e a sua pertinência analítica não pode dissociar-se do modus operandi de cada sistema nacional de relações laborais da "Europa dos 28" e, consequentemente, do modo como cada um dos sistemas se predispõe a valorizar ou não o papel dos CEEs. As perspetivas dos estudiosos do tema e, portanto, a atenção que conferem aos CEEs tende a valorizar diferentes tipos de abordagens: as tradições de diálogo social nacional e a forma com os CEEs beneficiam de um aquis instalado; a expressão quantitativa dos CEEs em geral; a relevância setorial dos CEEs; as análises dos acordos voluntários e dos acordos formais de CEEs de forma comparada no quadro europeu; o papel das tipologias de CEEs e a sua eficácia efetiva; o valor da comunicação inter e intra-CEEs; o funcionamento da consulta e a informação no papel e na prática; o timing da informação e consulta; as experiências de representantes de

\footnotetext{
${ }^{2}$ No caso português, e contrariamente à transposição tardia da Diretiva 94/45/CE para o direito interno, a Diretiva 2009/38/CE foi inclusive (de forma até algo surpreendente) uma das primeiras a ser transposta, podendo ser consultada através da lei 96/2009 de 3 de setembro.
} 
trabalhadores; os obstáculos que limitam a constituição e o funcionamento dos CEEs; a visão das entidades empregadoras; o perfil sociográfico dos representantes em CEEs; os processos de melhoria (revisão, reformulação) da lei comunitária; o papel dos sindicatos/federações sindicais europeias nos CEEs; os CEEs e a identidade laboral transnacional, etc.

Estas (e outras possibilidades) de abordar o tema dos CEEs mostram-nos, efetivamente, que estamos perante uma variedade de ângulos de análise, não obstante alguns deles serem complementares. Não surpreende, pois, que vários contributos interdisciplinares possam encontrar-se vertidos naquelas várias formas de estudar os CEEs, nomeadamente contributos da sociologia, do direito, da ciência política, da gestão de recursos humanos, da economia, da história ou mesmo da psicologia. Ora, também este estudo faz algumas incursões (mesmo que breves) por alguns daqueles domínios disciplinares das ciências sociais não obstante os contributos da sociologia serem aqui privilegiados.

Este estudo complementa e atualiza algumas das escassas investigações realizadas em Portugal sobre os Conselhos de Empresa Europeus (Costa, 1996; Costa e Araújo, 2007b; 2009). Na verdade, sempre que considerarmos oportuno faremos referência, de modo comparado, aos resultados a que chegámos nesta investigação com os resultados daqueles estudos. De um ponto de vista formal, este livro encontra-se estruturado em 5 capítulos. Os dois primeiros capítulos fornecem um enquadramento temático e teórico mais vasto sobre os CEEs. No capítulo 1, além de se situar o contexto necessário a uma regulação social da atividade das multinacionais, fornece-se uma explicação dos antecedentes da Diretiva 94/45/CE, situam-se os objetivos e funções dos CEEs e procede-se a uma análise das principais transformações associadas ao processo de revisão da Diretiva dos CEE e às novas configurações que passou a assumir com a entrada em vigor da Diretiva 2009/38/CE. No capítulo 2, por seu lado, procede-se a uma revisão crítica de algumas obras que se têm dedicado ao tema dos CEEs e que, portanto, dão testemunho de alguns dos tipos de abordagens mencionados acima. O papel das tipologias de CEEs e das "boas práticas" são igualmente referenciados. 
A segunda parte da obra ocupa-se de aspetos quantitativos e normativos associados aos CEEs nos setores em análise: metalúrgico, químico e financeiro. Como se evidencia ao longo deste trabalho, a escolha destes setores obedeceu a dois requisitos. Por um lado, os setores metalúrgico e químico são aqueles que, na maior parte dos estudos internacionais sobre os CEEs, bem como das bases de dados quer do Instituto Sindical Europeu, quer da Social Development Agency, aparecem como os mais representativos, tanto em número de multinacionais abrangidas pela Diretiva dos CEEs, como em número de CEEs constituídos. Por outro lado, o setor financeiro, além de ser, por norma, o $4 .^{\circ} \mathrm{em}$ termos de empresas abrangidas para a constituição de CEEs e de CEEs efetivamente constituídos, foi selecionado por ser o único em Portugal onde existe um CEE constituído com base numa multinacional com sede neste país. Assim sendo, no capítulo 3, tendo por base a European Works Councils Database (http://www.ewcdb.eu/), elucida-se a expressão quantitativa dos CEEs naqueles três setores em Portugal, dando-se conta, entre outros pontos, do peso das multinacionais, dos países e do status quo do CEE por setor de atividade. No capítulo 4, por sua vez, procede-se a uma análise dos acordos de CEEs envolvendo representantes portugueses nos setores metalúrgico, químico e financeiro. Os acordos em vigor por país de sede das multinacionais e por setor de atividade, os representantes portugueses por países e setor de atividade e uma análise pormenorizada da natureza dos acordos (tipo de acordo, subscritores, legislação aplicável, duração do acordo, composição do CEE, carácter abrangente versus carácter restrito dos acordos, oportunidade da informação e da consulta, formas de eleição dos representantes, modo de funcionamento das reuniões, etc.) são os principais aspetos trabalhados.

Por fim, na terceira parte, incorporam-se testemunhos de protagonistas portugueses associados ao funcionamento dos CEEs. Nesse sentido, no capítulo 5, após um breve enquadramento sobre os setores em análise de modo a perceber o tipo de questões/problemas por cada setor de atividade, escuta-se a visão dos representantes de trabalhadores portugueses em CEEs. Confere-se uma atenção especial a três estudos de caso - Autoeuropa (CEE da VW/setor metalúrgico), Air Liquide (CEE da 
Air Liquide/setor químico) e Banco Espírito Santo (CEE do BES/setor financeiro) - de modo a salientar em cada um deles os procedimentos de "boas práticas" associados ao funcionamento dos CEEs. Em complemento à visão dos representantes de trabalhadores em CEEs, concede-se ainda algum espaço ao modo como as entidades patronais (administradores/ departamentos de recursos humanos) percecionam o papel dos CEEs. 
(Página deixada propositadamente em branco) 


\section{CAPÍT UL O 1}

\section{A NECESSÁRIA REgULAÇÃO SOCIAL DAS MULTINACIONAIS E PAPEL DOS CONSELHOS DE EMPRESA EUROPEUS}

Este capítulo tem um triplo objetivo. Por um lado, visa situar o contexto de regulação social das multinacionais, chamando a atenção para a necessidade, cada vez mais urgente, de promover uma articulação entre o trabalho realizado nas multinacionais e os direitos humanos. Alguns instrumentos instigadores de um reconhecimento das formas de participação laboral nas multinacionais são mencionados a título de exemplo. Além disso, passam-se em revista vários contributos do direito comunitário em matéria laboral. Na sequência desse enquadramento normativo inicial, a segunda secção dá prioridade, ainda que de forma breve, aos antecedentes da Diretiva 94/45/CE (de 22.09.1994), relativa à informação e consulta dos trabalhadores nas multinacionais e à constituição de Conselhos de Empresa Europeus (CEEs) ou Procedimentos de Informação e Consulta (PICs) dos trabalhadores das empresas de dimensão comunitária. Por fim, analisa-se o processo de revisão da Diretiva 94/45/CE que se encontrava previsto, nos termos do artigo $15 .^{\circ}$ daquela lei comunitária, desde 1999, mas apenas foi consumado em 2009, através da Diretiva 2009/38/CE (de 6.05.2009). Na derradeira secção são, pois, trabalhadas as principais fundamentações associadas ao "discurso reinvindicativo" dos defensores do processo de revisão da Diretiva, bem como as principais mudanças resultantes da Diretiva 2009/38/CE. 


\section{Multinacionais e formas de participação laboral}

De par com o tradicional papel regulador dos Estados no domínio dos direitos sociais e da proteção social dos cidadãos, as multinacionais são hoje atores incortornáveis da cena internacional onde os padrões laborais e as "boas práticas" podem e devem ter lugar de modo mais frequente. Como referem Teles e Albuquerque (2008: 206), além dos Estados e as organizações internacionais, as empresas multinacionais são novas candidatas à qualidade de sujeito de direito internacional, desde logo porque se tornaria indispensável submeter as multinacionais a regras internacionais que, porém, não têm sido vinculativas.

\subsection{Das ações voluntaristas...}

Centenas de multinacionais têm vindo, nos últimos anos, a aderir ao Global Compact das Nações Unidas, uma carta de princípios de responsabilidade social de adesão voluntária. Tendo partido de uma iniciativa do ex-Secretário-Geral das Nações Unidas, Kofi Annan, no Fórum Económico Mundial de Davos (em janeiro de 1999), o Global Compact veio estabelecer um conjunto de princípios que gravitam, essencialmente, em torno do respeito pelos direitos humanos, pelos direitos laborais e pelo meio ambiente, que as empresas são aconselhadas a seguir, embora seja de adesão voluntária. 3

A Organização Internacional do Trabalho (OIT), por sua vez, adotou a Declaração Tripartida de Princípios Respeitantes às Empresas Multina-

\footnotetext{
3 Os dez princípios do Global Compact que as empresas devem cumprir são: no domínio dos direitos bumanos 1) apoiar e respeitar a proteção dos direitos humanos internacionalmente proclamados; 2) assegurar que não são cúmplices na violação dos direitos humanos; no domínio dos direitos laborais 3) promover a liberdade de associação e reconhecer o direito à negociação coletiva; 4) promover a eliminação de todas as formas de trabalho forçado e obrigatório; 5) promover a efetiva abolição do trabalho infantil; 6) promover a eliminação da discriminação em matéria de emprego; no domínio do ambiente 7) apoiar o princípio da adoção de medidas preventivas relativas aos problemas ambientais; 8) adotar iniciativas que promovam uma maior responsabilização ambiental; 9) encorajar o desenvolvimento e difusão de tecnologias amigas do ambiente; no domínio do combate à corrupção 10) lutar contra a corrupção em todas as suas formas. A este propósito consulte-se www. unglobalcompact.org ou ainda www.business-humanrigths.org e Teles e Albuquerque (2008).
} 
cionais e Política Social, pronta para ser subscrita voluntariamente pelas empresas, para além da já existente carta de normas fundamentais que é a Declaration on Fundamental Rights and Principles at Work, de 1998. De igual modo, também a Organização para a Cooperação e Desenvolvimento Económico (OCDE) estabeleceu as Diretrizes para as Empresas Multinacionais, cobrindo áreas como os direitos humanos, a corrupção, os impostos, as relações laborais, o ambiente, os direitos do consumidor, entre outras. Estas orientações, a par da carta de princípios da OIT, são as únicas que beneficiam do compromisso por parte dos governos que as subscreveram de promoção da sua efetiva observância por parte das empresas. No entanto, em caso de violação das orientações da OCDE não estão previstas sanções formais às empresas.

Em relação aos códigos de conduta ou códigos de ética propostos e adotados individualmente pelas empresas, estima-se que o seu número atual já ultrapasse os 10.000. O seu conteúdo pode variar de empresa para empresa: "Alguns não passam de vagas dissertações de boas intenções, outros têm cláusulas detalhadas sobre o respeito pelos direitos humanos e condições de trabalho, padrões ambientais, entre outros, e especificam a forma de cumprimento dos princípios por parte da empresa através das suas atividades globais" (ICTU, 2006: 19). Trata-se, em geral, de iniciativas unilaterais desencadeadas pelas administrações das empresas e onde é comum os sindicatos estarem ausentes. A tendência atual é para as empresas aderirem a estes códigos de conduta ou de boas práticas, produtos da soft law laboral, que não cria obrigações legais a quem os subscreve. A proliferação destas "normas privadas” nas empresas insere-se na tendência de desregulação e de flexibilização das leis do trabalho, defendida hoje como a melhor forma de responder ao imperativo da competitividade empresarial (Costa, 2008b: 48-49).

A participação dos representantes dos trabalhadores no desenvolvimento de códigos de conduta é considerada essencial por vários motivos (Schomann, 2004: 147): para além do facto de 1) terem um interesse legítimo e específico no emprego e nas questões económicas da empresa, 2) a sua participação irá, em parte, ultrapassar qualquer hiato de legitimidade ainda existente, uma vez que as empresas não podem dizer que defen- 
dem o interesse geral mas tão só interesses específicos, e irá potenciar o diálogo e ajudar à melhor implementação dos códigos. A sua participação irá, ainda, 3) tornar os códigos de conduta mais efetivos, uma vez que estes poderão assumir a forma de contratos privados ou, na melhor das hipóteses, de um acordo coletivo, permitindo aos sindicatos exercer pressão sobre a empresa na eventualidade de não cumprimento do código.

Os Acordos-Quadro Globais (A-QG) são outro importante instrumento de participação laboral nas multinacionais (International Union Rigths, 2011). E provavelmente com potencialidades para gerar melhores resultados do que os códigos de conduta, constituindo mesmo, nesse sentido, um possível veículo de responsabilidade social empresarial (Costa, 2011). Uma síntese de alguns aspetos vantajosos dos A-QG face aos códigos de conduta encontra-se em Schömann et al. (2008), sendo de destacar:

- O comprometimento dos A-QG com direitos sindicais, direitos de negociação coletiva, informação e consulta da força de trabalho;

- O foco em questões relacionadas com direitos laborais e relações laborais nas multinacionais, tendo sempre por referência o papel orientador da OIT;

- A capacitação para o reforço do diálogo social internacional;

- A valorização preferencial dos labour standards;

- O envolvimento dos parceiros sociais na implementação e monitorização dos $A Q-G$;

- A opção pela via do diálogo em vez da via da sanção. A ideia é a de que as partes subscritoras do A-QG identifiquem possíveis violações de direitos sociais fundamentais nas filiais ou mesmo entre os fornecedores, mas procurando resolver os problemas internamente, pelo diálogo social, em vez de ir a tribunal e chamando a atenção do público em geral;

- Maximização de uma abordagem pragmática às relações laborais e do diálogo social, realçando a importância de "exportar" um certo modelo social europeu (ou doméstico) de relações empregador/ empregado. 


\section{2. ... à necessária normatividade laboral}

Mas o complemento necessário a estes instrumentos de participação laboral de cariz voluntário passará certamente pela criação de condições para um reforço da normatividade laboral transnacional. Na opinião de Michael Gold (2007: 24-25), a UE tem vindo a privilegiar as formas representativas ao nível do local de trabalho, da empresa e do grupo e a informação e consulta, ao invés da negociação. As medidas que têm vindo a ser adotadas procuram dar maior capacidade de influência aos trabalhadores em fases precoces dos processos de decisão e em questões que têm uma influência substancial nas suas vidas. Para Gold podem apontar-se quatro argumentos a favor do interesse da Comissão Europeia na maior participação dos trabalhadores: harmonização legislativa ao nível da empresa; conceção da participação enquanto fator produtivo; prevenção do dumping social; incorporação de fatores políticos, tais como pressões sindicais e políticas a favor dos direitos dos trabalhadores.

Mas vale a pena fazer uma incursão pelos instrumentos de legislação social comunitária (Silva, 2008). Para este autor, o direito comunitário do trabalho configura-se como um corpo significativo de normas jurídicas com influência crescente no modo como se regulam a nível nacional as relações de trabalho tanto individuais como coletivas. Os principais direitos na esfera do trabalho encontram-se inscritos na Carta Comunitária dos direitos fundamentais da União Europeia (proclamada em Nice, em 2000, e incluída formalmente no novo Tratado por deliberação da Conferência Intergovernamental de 23 de julho de 2007). Mas uma vez que a União Europeia (UE) não é dotada de competências exclusivas no domínio social, o direito do trabalho exerce uma função supletiva e não substitutiva em relação aos direitos nacionais individuais de cada país. Além disso, como sublinha Silva (2008: 204), a Europa Social (conjunto de normas com expressão jurídica e de aplicação alargada ao conjunto da Comunidade) é uma realidade relativamente recente.

Foi no decorrer das duas últimas décadas que um conjunto de medidas legislativas mais se desenvolveu, concedendo eficácia jurídica a uma varie- 
dade de direitos sociais elementares inscritos na Carta Social do Conselho da Europa ou na Carta comunitária dos direitos sociais fundamentais.

Dois momentos marcaram essa evolução: No período entre 1986 e 1994 foram adotados 33 instrumentos legislativos no domínio social (24 novos e 9 revisões). O Ato Único Europeu em 1986 introduziu no Tratado um novo artigo (118 A) que deu ao legislador europeu a possibilidade de, através da regra da maioria qualificada, adotar diretivas no domínio social com o objetivo de harmonizar as regras de saúde e segurança no trabalho no quadro do Mercado Interno. Por outro lado, no período entre 1996 e 2002 foram igualmente adotados 33 instrumentos legislativos (19 novos e 14 revisões). É um período marcado pelo alargamento das competências legislativas da Comunidade. Com a introdução do Artigo 137 no Tratado de Amsterdão, em 1997, generaliza-se a regra da maioria qualificada para a adoção das diretivas no domínio social. Estes dois períodos importantes do ponto de vista do reforço da dimensão social na Comunidade ocorrem em paralelo a dois projetos estratégicos de índole económica, designadamente o Mercado Interno e a União Monetária no espaço europeu.

Por sua vez, quando se atenta no conteúdo do direito do trabalho comunitário deve realçar-se a função de imposição aos Estados decorrente da adoção de diretivas comunitárias. Tratando-se da adoção de normas mínimas com o objetivo de harmonização progressiva dos direitos nacionais, as diretivas comprometem os Estados quanto aos resultados a atingir mas deixam-lhes uma grande margem de manobra em relação aos meios e à forma de os atingir.

Nos termos do artigo 137 do Tratado de Amesterdão podem apontar-se três áreas legislativas comunitárias fundamentais no domínio das relações de trabalho: saúde e segurança dos trabalhadores; condições de trabalho e; informação e consulta dos trabalhadores ${ }^{4}$. Nestas áreas a ado-

\footnotetext{
$4 \mathrm{Na}$ área da "Informação e consulta dos trabalhadores" são de destacar as seguintes Diretivas: Diretiva 94/45/CE, que permite a instituição de um conselho de empresa europeu ou de um procedimento de informação e consulta dos trabalhadores nas empresas e grupos de dimensão comunitária; Diretiva 98/59/CE do Conselho, sobre despedimentos coletivos; Diretiva 2001/23/CE, sobre a manutenção dos direitos dos trabalhadores em
} 
ção de legislação processa-se segundo o procedimento de co-decisão (o Conselho decide segundo a regra de maioria qualificada com base numa proposta da Comissão e com o acordo do Parlamento). Há, por outro lado, também áreas do direito do trabalho vetadas à iniciativa legislativa da Comissão: remunerações, direito de associação, direito de greve e o lock-out (Silva, 2008: 204).

Como frisa ainda Silva, o reforço dos direitos laborais comunitários foi também confirmado pelo alargamento da UE a 27 Estados-Membros, pelo que o desafio futuro passa não tanto pela expansão desse quadro legal mas mais pela melhoria da aplicação da legislação existente. Prevê-se que o fluxo de nova legislação na esfera do trabalho diminua e que se recorra de forma crescente a meios não legislativos, tais como os códigos de boas práticas, acordos autónomos entre parceiros sociais ou recomendações (como se viu na subsecção anterior). Para o mesmo resultado deverá também contribuir a dificuldade crescente de formar consensos no Conselho sobre matéria legislativa após o alargamento de 2004 (Silva, 2008: 205).

Um argumento utilizado no sentido de reformular a legislação laboral é o de que é preciso dotar os mercados de trabalho de maior flexibilidade, mas simultaneamente garantir maior segurança aos trabalhadores e combater a segmentação desses mercados. Estas linhas orientadoras da estratégia europeia de crescimento e emprego, lançada em 2000 e renovada em 2005, desaguaram no conceito de "flexigurança", institucionalizado em 2006 pelo Livro Verde da Comissão Europeia, relativo à modernização do direito do trabalho como forma de fazer face aos desafios do século XXI. No entanto, como adverte Silva (2008: 205), a existência de quadros legais rígidos em muitos países, por um lado, e a exigência de novos padrões de flexibilidade laboral, por outro, coloca a UE numa

caso de transferência de empresas ou de estabelecimentos; Diretiva 2001/86/CE, sobre o envolvimento dos trabalhadores na Sociedade Europeia; Diretiva 2002/14/CE, estabelecendo um quadro geral relativo à informação e consulta dos trabalhadores; Diretiva 2003/72/ $\mathrm{CE}$, sobre o envolvimento dos trabalhadores na Sociedade Cooperativa Europeia; Diretiva 2009/38/CE, que substitui a Diretiva 94/45/CE e permite a instituição de um conselho de empresa europeu ou de um procedimento de informação e consulta dos trabalhadores nas empresas e grupos de dimensão comunitária (Silva, 2008: 205). 
encruzilhada cuja saída deverá influenciar o desenvolvimento futuro do direito do trabalho, não só a nível comunitário como nacional. E sendo certo que o desafio se inscreve, em boa medida, na estratégia europeia para o emprego e é compatível com a orientação da Comissão Europeia na área da política económica e social em geral e da política de emprego em particular, não é menos verdade que a transposição da flexigurança para diferentes contextos depende da capacidade económica, da vontade política, dos sistemas de bem-estar social, do funcionamento das políticas ativas do mercado de trabalho ou simplesmente dos interesses dos atores em presença (Costa, 2009c: 141; 2012a: 105-106).

\section{Antecedentes da Diretiva 94/45/CE}

As discussões sobre a informação e consulta dos trabalhadores nas empresas multinacionais remontam à década de setenta do século XX e prolongaram-se nas décadas seguintes. Ainda assim, apenas em 22 de setembro de 1994 a Diretiva 94/45/CE criaria condições efetivas para a instituição de CEEs ou para a criação de PICs dos trabalhadores nas empresas ou grupos de empresas de dimensão comunitária.

Tratou-se do primeiro mecanismo legal emitido no quadro do Protocolo de Política Social e em cumprimento do Acordo sobre Política Social subscritos em Maastricht (1992). Reconheça-se, no entanto, que a importância da Diretiva extravasa o plano meramente jurídico na medida em que comporta uma dimensão política e simbólica fundamental, medindo-se igualmente a sua importância à luz do futuro do modelo europeu de concertação social e de relações laborais e à luz da europeização do diálogo social (Paternotre, 1998).

Como se disse, a Diretiva foi emitida no quadro do Protocolo de Política Social e em cumprimento do Acordo sobre Política Social subscritos em Maastricht. Todavia, o processo de informação e consulta dos trabalhadores nos fora comunitários havia sido lançado cerca de duas décadas antes. A adoção da Diretiva corresponde a um longo, complexo e, muitas vezes, controverso processo, sendo a Diretiva considerada como 
uma versão fragilizada e reduzida das propostas até então apresentadas sobre informação e consulta dos trabalhadores (Leite et al., 1996).

Como referem Danis e Hoffmann (1995: 181), desde 1973 que a Comissão Europeia propusera medidas para criar procedimentos regulatórios nas empresas multinacionais, incluindo uma propensão para a melhoria da transparência e das medidas sobre os direitos de informação dos trabalhadores. Porém, essa pretensão não teve efeitos práticos, como foi comprovado pelo insucesso da proposta (em 1970) de estatutos para uma "Empresa Europeia", que já previa um conselho de empresa com a concessão de certos direitos de informação, consulta e participação nas decisões sobre questões sociais. Os referidos estatutos foram, então, objeto de comentários críticos não só por parte das organizações de empregadores (que, de resto, a par do Reino-Unido, conservaram sempre uma postura de oposição frontal), como, inclusive, por parte dos sindicatos europeus que discordavam (ainda que de forma mais moderada) da estrutura de supervisão em causa.

Dez anos depois, em outubro de 1980, a Comissão Europeia viria a lançar uma nova proposta relativa à informação e consulta dos trabalhadores nas empresas transnacionais, que ficou conhecida como a "Diretiva Vredeling” (nome do então Comissário dos Assuntos Sociais, Henk Vredeling). O esboço da Diretiva salientava que as decisões importantes dos grupos de empresas multinacionais, ao serem tomadas recorrentemente nas sedes desses grupos, produziam consequências muitas vezes nefastas para os trabalhadores (como a deslocalização de empresas, por exemplo), ao passo que os direitos e possibilidades de ação dos trabalhadores e seus representantes ao nível da empresa se encontravam em grande medida limitados à legislação nacional. Daí que a primeira missão da Comissão apontasse no sentido de permitir aos trabalhadores a obtenção de informação das atividades do grupo além-fronteiras. Contrariamente às recomendações da Organização Internacional do Trabalho (OIT) e da Organização para a Cooperação e Desenvolvimento Económico (OCDE), que estabeleciam códigos de conduta para os grupos de empresas multinacionais sem carácter vinculativo, a "Diretiva Vredeling" obrigava as empresas envolvidas a informar e consultar os representantes dos traba- 
lhadores de todos os estabelecimentos, na medida em que isso poderia ser um fator gerador de consensos e preventivo da ocorrência de uma deterioração das relações de trabalho na empresa.

A proposta de Vredeling acabou por receber o apoio da Confederação Europeia de Sindicatos (CES), embora tenha sido confrontada com uma forte oposição por parte da União das Indústrias da Comunidade Europeia (UNICE), secundada pela postura igualmente adversa das multinacionais americanas, que consideravam a "Diretiva Vredeling" como uma ameaça à competitividade das empresas. ${ }^{5}$

Entretanto, as palavras-chave da Diretiva 94/45/CE - “informação” e "consulta" - estavam já mencionadas noutras iniciativas, constituindo, também estas, "estratégias de antecipação" dessa lei comunitária. 6 São exemplo destas:

- A “Carta Comunitária dos Direitos Sociais Fundamentais dos Trabalhadores" (1989), nos termos da qual a informação, consulta e participação dos trabalhadores deviam ser desenvolvidas de acordo com regras adequadas e tendo presente as práticas em vigor nos Estados-Membros (ponto 17);

- O "Programa de Ação para Aplicação da Carta Comunitária”, que vinha propor instrumentos normativos ${ }^{7}$ destinados a "evitar" a diversidade e a pugnar pela generalização dos princípios de informação, consulta e participação dos trabalhadores;

- Uma "Resolução" do Parlamento, de 15 de fevereiro de 1990, na qual se recomendava a "criação de comités consultivos no âmbito das empresas multinacionais"

\footnotetext{
5 Sobre as controvérsias em torno da "Diretiva Vredeling" e sobre outros antecedentes da Diretiva 94/45/CE, cf. Danis e Hoffmann (1995: 183-187), Knudsen (1995: 116-132), Danis (1996: 79-82), Rehfeldt (1993: 74-78), Reibsch (1998: 124-126), Fitzgerald (2004: 2-5), Gold (2007: 25 e ss.), Dølvik (2010) ou Waddington (2011: 5-13).

6 Para uma análise de mais recomendações, convenções, diretrizes ou instrumentos normativos emanados de organismos como a OIT e a OCDE ou ainda da UE, cf. Simões (1996: 10-12).

7 De que uma síntese se pode encontrar em Gaspar e Fiolhais (1996: 57-58).

${ }^{8}$ Jornal Oficial das Comunidades Europeias, n. ${ }^{\circ}$ C 68, de 19 de março de 1990.
} 
- E, como não poderia deixar de ser, um dos pontos do n. ${ }^{\circ} 1$ do artigo 2. ${ }^{\circ}$ do Acordo Social de Maastricht anexo ao Protocolo sobre Política Social.

Refira-se ainda que na base da Diretiva 94/45/CE esteve o projeto de Diretiva sobre informação e consulta dos trabalhadores nas empresas de dimensão comunitária apresentado pela Comissão Europeia em 12 de outubro de 1990.9 Posteriormente, essa proposta seria modificada, em 20 de setembro de 1991, com o intuito de incorporar sugestões do Parlamento Europeu e do Comité Económico e Social (CES-UE). ${ }^{10}$

\section{Objetivos e revisão da Diretiva dos Conselhos de Empresa Europeus}

O lugar dos CEEs assim como dos PICs dos trabalhadores das empresas de dimensão comunitária representa um avanço no ordenamento jurídico transnacional das matérias de ordem social, mesmo sabendo-se que a constituição de CEEs ou PICs foi atravessada por tensões e confrontos entre "euro-otimistas" (em especial representantes de organizações de trabalhadores) e "euro-pessimistas" (em geral, os empregadores europeus), e reconhecendo que se trata de um tema de intervenção e participação laboral que carece de maior consolidação e aprofundamento (Costa, 2005; Costa e Araújo, 2007b; 2009). A revisão da Diretiva 94/45/ CE (de 22.09.1994) e a sua substituição pela Diretiva 2009/38/CE (de 6.05.2009) ${ }^{11}$ resulta de um longo processo que, de certo modo, justificava a necessidade de encontrar uma via alta para os CEEs.

${ }^{9}$ Jornal Oficial das Comunidades Europeias, n. ${ }^{\circ}$ C 39, de 15 de fevereiro de 1991, pp. 10-15.

${ }^{10}$ Jornal Oficial das Comunidades Europeias, n. ${ }^{\circ}$ C 336, de 31 de dezembro de 1991, pp. 11-24.

11 Como já antes se referiu, sempre que aparecer a expressão "velha Diretiva" ela reporta-se à Diretiva 94/45/CE, ao passo que sempre que aparecerem as expressões "nova Diretiva" ou "Diretiva reformulada" estas reportam-se à Diretiva 2009/38/CE, em vigor desde 6 de Junho de 2011. 
Importa, pois, identificar as principais transformações decorrentes da "passagem de testemuho" de uma Diretiva a outra. Daí que, por um lado, se recupere, de forma necessariamente breve, a missão e objetivos dos CEEs na sua conceção original. Seguidamente, indicam-se as principais razões para rever a Diretiva (nomedamente do ponto de vista sindical/ laboral), bem como alguns estudos a partir dos quais se consegue captar o modo como os representantes de trabalhadores em CEEs (afinal os principais destinatários dos CEEs) perspetivam os CEEs, em especial as suas limitações que tornaram o processo de revisão da Diretiva inevitável. Por fim, sistematizam-se algumas das principais mudanças associadas à Diretiva 2009/38/CE. Não se trata aqui de entrar em todos os detalhes que uma análise jurídica mais fina certamente reclamaria ${ }^{12}$, mas sim de reunir alguns contributos interpretativos e implicações de relevância social e jurídica decorrentes da nova lei comunitária.

\subsection{Missão e objetivos da Diretiva 94/45/CE}

Como afirmam Costa e Araújo (2007c: 6-8), a emergência da Diretiva 94/45/CE (de 22.09.1994) - que tornou possível a constituição de CEEs ou PICs - insere-se numa luta que há muito vinha sendo travada no contexto europeu no sentido de fazer corresponder à crescente operação das empresas à escala transnacional mecanismos de representação e participação dos trabalhadores adequados a essa escala. Isto é, expandindo-se a esfera de ação das multinacionais era imperativo que se expandisse também a esfera de atuação dos trabalhadores. Simples na sua formulação, o processo para a criação desses mecanismos, revelar-se-ia longo, complexo e até controverso. ${ }^{13}$ Mesmo que a adoção da Diretiva 94/45/ CE possa ter assumido a forma de uma versão fragilizada das propostas até então apresentadas sobre informação e consulta dos trabalhadores,

\footnotetext{
12 Para uma análise mais detalhada e fundamentada das principais alterações normativas associadas à Diretiva 2009/38/CE, consultem-se, entre outros, Blainpain (2009), Dorssement e Blank (orgs, 2010), Picard (2010) ou Waddington (2011: capítulo 7).

13 Para uma análise dos antecedentes da Diretiva 94/45/CE, cf. Costa (2005: 607-610).
} 
não deixou de configurar-se como um importante instrumento jurídico de reforço da representação e participação laboral nas multinacionais. A emergência da Diretiva suscitou, assim, um conjunto de expectativas, nomeadamente quanto ao reforço da europeização do diálogo social (Paternotre, 1998), ao incremento da democracia laboral (Buschak, 1995), ao estabelecimento de redes de comunicação entre representantes dos trabalhadores e estruturas de representação (Wills, 2000) e a um renovado fôlego para a ação sindical e para a reivindicação coletiva (Lecher et al., 1999; Wills, 2004; Telljohann, 2005a). Em última análise, procura-se a edificação de uma identidade laboral europeia (Whittall, Knudsen e Huijgen, 2007).

O objetivo principal da Diretiva 94/45/CE consistiu em "melhorar o direito à informação e consulta dos trabalhadores nas empresas ou grupos de empresas de dimensão comunitária" (n. ${ }^{\circ} 1$ do art. $\left.1 .^{\circ}\right) .^{14}$ As oportunidades emergentes oferecidas pela Diretiva englobavam, deste modo, a concessão de direitos de informação - sobre "questões transnacionais suscetíveis de afetar consideravelmente os interesses dos trabalhadores" (art. 6. ${ }^{\circ}$, n. $^{\circ}$ 3) - e direitos de consulta - a "troca de opiniões e o estabelecimento de um diálogo entre os representantes dos trabalhadores e a direção central ou qualquer outro nível de direção mais apropriado" (art. 2. ${ }^{\circ}$, n. ${ }^{\circ}$ 1, al. f).

Como já se referiu, a Diretiva 94/45/CE consagrou dois mecanismos de informação e consulta dos trabalhadores nas empresas/grupos de empresas de dimensão comunitária: os CEEs ou os PICs. Uma vez aberto o processo negocial ${ }^{15}$, o passo seguinte consistia na formação de um

${ }^{14}$ A "empresa de dimensão comunitária" emprega mil ou mais trabalhadores nos Estados-Membros e em pelo menos dois Estados-Membros diferentes emprega um mínimo de cento e cinquenta trabalhadores em cada um deles (art. $2 .^{\circ},{ }^{\circ} .^{\circ} 1$. al. a). Por sua vez, o "grupo de empresas de dimensão comunitária" emprega pelo menos mil trabalhadores nos Estados-Membros, que possui, no mínimo, duas empresas membros do grupo em Estados-Membros diferentes, sendo que cada uma dessas duas empresas deve empregar, no mínimo, cento e cinquenta trabalhadores (art. $2 .^{\circ}, \mathrm{n} .^{\circ} 1 .$, al. c).

15 A abertura do processo negocial para a instituição de um CEE ou de um PIC pode ser desencadeada: a) por proposta, oral ou escrita, da direção central ou b) por requerimento dos trabalhadores, este último, "mediante pedido escrito de, no mínimo, 100 trabalhadores, ou dos seus representantes, provenientes de pelo menos duas empresas ou estabelecimentos situados em pelo menos dois Estados-Membros diferentes" (art. 5. ${ }^{\circ},{ }^{\circ}{ }^{\circ}$ ). 
Grupo Especial de Negociação (GEN) (art. 5. ${ }^{\circ}$ ) composto por representantes dos trabalhadores (art. $5 .^{\circ}$, n. ${ }^{\circ}$ 2, al. b). Entretanto, concedeu-se aos Estados-Membros a competência para determinar o modo de eleição ou de designação dos membros do GEN que devem ser eleitos ou nomeado no seu território (art. $5^{\circ}$, n. ${ }^{\circ}$, a). Porém, nas eleições ou nomeações deve assegurar-se: a) a existência de um representante por cada Estado-membro no qual a empresa de dimensão comunitária possua a empresa que exerce o controlo ou uma ou mais empresas controladas; b) a existência de representantes suplementares em número proporcional ao dos trabalhadores dos estabelecimentos, da empresa que exerce o controlo ou das empresas controladas nos termos da legislação do Estado-membro em cujo território se situa a direção central (art. $5 .^{\circ}$, n. ${ }^{\circ}$ 2). A direção central e direções locais são, posteriormente, informadas da composição do GEN (art. 5. ${ }^{\circ},{ }^{\circ}{ }^{2}$, d).

Posteriormente deve adotar-se um dos mecanismos de informação e consulta (CEE ou PIC) e celebrar-se o respetivo acordo (art. 6. ${ }^{\circ}$ ). Cabe deste modo ao GEN fixar, em colaboração com a direção central e mediante acordo escrito, o âmbito de ação, a composição, as atribuições e a duração do mandato dos CEEs ou as regras de execução dos PICs (art. 5. ${ }^{\circ}$, n. ${ }^{\circ}$ 3). $\mathrm{O}$ acordo escrito funciona, pois, como guia da atividade futura dos CEEs. $\mathrm{Na}$ verdade, as regras segundo as quais os representantes dos trabalhadores têm o direito de se reunir para proceder a uma troca de opiniões sobre as informações que lhes são comunicadas ficam determinadas nos acordos. A Diretiva estabelece, porém, alguns requisitos básicos. Assim, os CEEs têm o direito a reunir com a direção central uma vez por ano de modo a que os trabalhadores possam ser informados e consultados, com base num relatório elaborado pela direção central, sobre a evolução das atividades da empresa ou grupo de empresas de dimensão comunitária e sobre as suas perspetivas. A reunião deve incidir sobre um conjunto de pontos que se encontram previstos no anexo 2 da Diretiva 94/45/CE:

\footnotetext{
- a estrutura da empresa;

- a situação económica e financeira;

- a evolução provável das atividades, produção e vendas;
} 
- a situação e evolução provável do emprego;

- os investimentos;

- as alterações de fundo relativas à organização;

- a introdução de novos métodos de trabalho ou de novos processos de produção;

- as transferências de produção;

- as fusões, a redução da dimensão ou encerramento de empresas, de estabelecimentos ou de partes importantes de estabelecimentos;

- os despedimentos coletivos.

Tendo em conta esses requisitos, os acordos negociados com base no artigo $6 .^{\circ}$, ou seja, depois da entrada em vigor da Diretiva a 22 de setembro de $1996^{16}$, estabelecem os modos de funcionamento dos CEEs, incluindo as empresas do grupo de empresas de dimensão comunitária ou os estabelecimentos da empresa de dimensão comunitária abrangidos pelo acordo (art. 6. ${ }^{\circ},{ }^{\circ}{ }^{2}$, al. a); a composição do CEE, bem como o número de membros, a distribuição dos lugares e a duração do mandato (art. $6 .^{\circ},{ }^{\circ}{ }^{\circ}$ 2, al. b) (as partes possuem aqui discricionariedade total para escolher os membros e respetivo número; definir se o CEE é composto apenas por trabalhadores da multinacional ou incluir outros representantes como sejam peritos ou representantes de organizações sindicais); as atribuições e o procedimento de informação e consulta do CEE (art. $6 .^{\circ}$, n. ${ }^{\circ} 2$, al. c); o local, a frequência e a duração das reuniões do CEE (art. 6. ${ }^{\circ}, \mathrm{n} .^{\circ} 2$, al. d); os recursos financeiros e materiais a afetar ao CEE (art. $6 .^{\circ},{ }^{\circ}{ }^{\circ} 2$, al. e); e a duração do acordo e o seu processo de renegociação (art. 6. ${ }^{\circ},{ }^{\circ}{ }^{\circ}$, al. f).

\subsection{Principais razões para rever a Diretiva}

Nos termos do artigo $15 .^{\circ}$ da Diretiva 94/45/CE, esta deveria ter sido revista até setembro de 1999, depois de consultados "os Estados-Membros

16 Os acordos negociados antes da entrada em vigor da Diretiva, designados de voluntários ou de antecipação à Diretiva, são reconhecidos pela Diretiva nos termos do seu artigo $13 .{ }^{\circ}$. 
e as organizações representativas dos trabalhadores e empregadores ao nível europeu". Com o apoio da Comissão Europeia, os parceiros sociais europeus - Confederação Europeia de Sindicatos (CES), União das Indústrias da Comunidade Europeia (UNICE) ${ }^{17}$ e Centro Europeu das Empresas de Participação Pública (CEEP) - realizaram um encontro em 28-30 de abril de 1999 intitulado "Conselhos de Empresa Europeus: prática e desenvolvimento" com vista e discutirem a necessária revisão da Diretiva. Porém, este encontro veio apenas confirmar a visão divergente que empregadores e trabalhadores tinham sobre a necessidade de rever/ reformular a Diretiva. Uma vez que até setembro de 1999 a Comissão Europeia não tinha feito qualquer ação concreta para proceder à revisão da Diretiva, a CES, em dezembro do mesmo ano, divulgou uma resolução que pretendeu chamar a atenção da Comissão para a sua obrigação de revisão da Diretiva.

\subsubsection{As posições da CES}

Como lembram Costa (2005: 619-620) e Jagodzinski (2009: 115-116), várias questões passaram a preocupar a CES e os trabalhadores em geral18 em relação à Diretiva dos CEEs:

- Garantir que a informação seja transmitida aos trabalhadores com antecedência (de modo a ser estudada com rigor), de uma forma regular e por escrito, em todas as línguas dos representantes de modo a aligeirar os obstáculos à compreensão das matérias;

17 A UNICE passou a designar-se Business Europe desde 2007 (www.businesseurope.eu).

18 Sobre as propostas da CES, cf. ETUC (1999; 2001). Para uma análise sobre as opiniões que vários estudiosos dos CEEs emitiram no contexto inicial em que se aguardava a revisão da Diretiva, cf. Lecher (1999: 298-301), Miller (1999: 359-362), Blanke (1999a: 49; 54-56; 1999b: 380-382), Buschak (1999a: 386-392; 1999b: 60-65; 2000: 161-172), Kerckhofs (2000: 145-150), Waddington (2002: 183-186), Hall (2003) ou Waddington e Kerckhofs (2003: 335-338). 
- Assegurar que a consulta dos trabalhadores se faça sempre com a devida antecedência;

- Assegurar a qualidade da informação facultada pelas direções das empresas aos trabalhadores, sobretudo quando estão em causa reestruturações empresariais;

- Salvaguardar o direito dos CEE serem informados sobre medidas previstas e não somente as já implementadas;

- Reduzir a abrangência da Diretiva de 1.000 para 500 trabalhadores no Espaço Económico Europeu (EEE) e de 150 para 100 em pelo menos dois Estados-membros;

- Clarificar a noção de "confidencialidade";

- Fazer menção explícita às Federações Sindicais Europeias (FSEs), de âmbito setorial, como parte a ser informada da composição do GEN. Ou seja, garantir a participação de um representante das FSEs quer nos GENs, quer nos CEEs para assegurar uma melhor coordenação e apoio à ação dos representantes dos trabalhadores;

- Garantir que o GEN possa ser assistido por peritos à sua escolha e que estes participem nas negociações com a direção central;

- Garantir o acesso à formação tanto em línguas como em matérias mais técnicas, de modo a melhorar a participação dos representantes;

- Estabelecer sanções para os casos de desrespeito do estabelecido na Diretiva e a possibilidade, por parte dos CEEs, de levantar processos judiciais no caso de incumprimento dos acordos ou do estabelecido pela Diretiva;

- Encurtar o período de negociações de um acordo para o máximo de um ano, cujo limite está atualmente fixado nos três anos após o início do processo;

- Clarificar os termos de renegociação dos acordos;

- Conferir uma maior eficácia geral à formação dos representantes dos trabalhadores;

- Criar a possibilidade dos representantes dos trabalhadores transitarem entre todas as sucursais da multinacional;

- Garantir a realização de reuniões preparatórias e posteriores às reuniões ordinárias; 
- Apelar à Comissão para o reconhecimento oficial urgente de que sempre que as decisões empresariais sejam tomadas sem a consulta aos CEEs as mesmas sejam consideradas nulas ou sem efeito.

\subsubsection{As visões dos representantes de trabalhadores em CEEs}

Entretanto, no início do século XXI, alguns estudos sobre a perceção que representantes de trabalhadores em CEEs expressavam sobre o funcionamento destes chamavam igualmente a atenção para pontos que se articulavam de perto com a necessidade de reformular a Diretiva. Dois desses estudos foram conduzidos por Jeremy Waddington (2003; 2006a). $\mathrm{O}$ primeiro estudo consistiu na aplicação de um inquérito a representantes de CEEs de seis países europeus (Alemanha, Irlanda, Grã-Bretanha, Suécia, Holanda e Finlândia) ${ }^{19}$, tendo trabalhado variáveis como a nacionalidade, a função do representante na empresa do CEE e o país de origem da multinacional. Constatou-se um descontentamento generalizado em relação ao funcionamento dos CEEs, em particular no que respeita ao alcance da agenda e à qualidade da informação e da consulta. Simultaneamente, verificou-se um crescente apoio dos parceiros sociais à revisão da Diretiva, em especial nas áreas que melhorem a qualidade da informação e da consulta.

19 O questionário foi concebido pelo autor em colaboração com os representantes das organizações participantes. Foi distribuído entre 1999 e 2000 por correio ou email. 840 inquéritos foram enviados e 558 devolvidos, com uma taxa de devolução de 66,4\%. Por país, a taxa de devolução variou entre os 40,2\% na Finlândia e os 94,4\% na Suécia. 87,1\% dos respondentes eram do sexo masculino, com uma média de idades de 48 anos. Excluindo nove representantes de CEEs não sindicalizados alemães, todos os restantes pertenciam a sindicatos. Os inquiridos eram trabalhadores de 222 multinacionais com base em 17 países. Assinale-se ainda que ao partir do pressuposto de que a amostra não é representativa de toda a Europa, Waddington agrupou 6 países em três categorias: Dois, Irlanda e Reino Unido, com uma tradição voluntarista de relações laborais compreendendo um único canal de representação (sindical), pluralismo sindical, largas áreas de não-influência sindical e negociação coletiva ao nível da empresa; Dois, Alemanha e Holanda, com uma tradição legal ou jurisdicional no centro da qual se encontram sistemas duais de representação dos trabalhadores; Dois: Finlândia e Suécia, com uma elevada densidade sindical, um único canal de representação, dependência da negociação coletiva para regular o quadro da representação, cobertura negocial relativamente alargada e a articulação da negociação coletiva ao nível da empresa com outra de um nível mais elevado. 
$\mathrm{O}$ inquérito aplicado pretendeu apurar se os representantes dos CEEs consideravam que os objetivos básicos relativos à informação e consulta estavam ou não a ser atingidos e o que poderia explicar as variações na qualidade da informação e da consulta. Adicionalmente, foi também feita uma questão sobre se o tema dos direitos sindicais tem aparecido na agenda dos CEEs (Waddington, 2003: 310). Ora, a velha Diretiva revelava-se omissa em relação à "qualidade" da informação e do processo de consulta, em particular no que se refere à forma e ao timing. Deste modo, procurou-se captar a visão dos representantes dos CEE sobre o conjunto de assuntos em que a informação incide, apurar se a forma e o timing foram os apropriados (úteis), e se, de facto, a consulta genuína teve ou não lugar. Os temas da agenda dos CEE alvo de informação e consulta foram variados: situação económica e financeira; estratégia empresarial e planos de investimento; mudanças nos métodos de trabalho; encerramentos ou reduções de pessoal; fusões, aquisições; nova política tecnológica; reorganização das linhas de produção; transferências/relocalização da produção; níveis de emprego e previsões; política de investigação e desenvolvimento; formação; igualdade de oportunidades; saúde e segurança; proteção ambiental; direitos sindicais; tempo de trabalho; licença parental; entre outros.

Não cabe aqui retomar a frequência com que estes assuntos aparecem na agenda dos CEEs, a qual é, em si mesma, muito variável. Valerá apenas realçar dois deles: por um lado, sobre um tema central para os representantes dos trabalhadores, a "evolução do emprego", constatou-se que quase $40 \%$ dos representantes inquiridos afirmaram não ter havido qualquer discussão sobre as perspetivas de "evolução do emprego" na empresa, ao contrário daquilo que a Diretiva determinava; por outro lado, a questão dos "direitos sindicais" era apontada como "não levantada" por quase 3/4 dos representantes, o que revelava o escasso progresso no desenvolvimento de laços entre os CEEs e os sindicatos.

Mas um tanto à semelhança das posições da CES sobre os pontos a rever na velha Diretiva (mencionados acima), este inquérito procurou conhecer a visão dos representantes dos CEEs sobre o programa da revisão, cuja forma abarcava três grandes linhas: extensão da cobertura, 
qualidade da informação e da consulta e aspetos processuais. Foi pedido aos inquiridos para classificarem um conjunto de elementos numa escala que ia do "concordo plenamente" até ao "discordo em absoluto". Foi pedida a opinião dos representantes sobre os seguintes tópicos: mais empresas abrangidas; inclusão de joint-ventures e empresas em regime de franchising; informação sobre um conjunto mais alargado de temas; limites temporais para a informação providenciada pela administração; consulta antes da administração implementar as decisões; direitos específicos durante as fusões ou aquisições; composição do CEE deve respeitar a força de trabalho segundo o género; mais ajuda para interpretar a informação; mais ajuda para as reuniões informais; ajuda para a formação; papel formal para os sindicatos.

Foi notório o apoio esmagador dos representantes a quase todos os aspetos do programa apresentado. Somente na "questão do género" é que menos de metade dos representantes disse concordar. O apoio ao tema da informação foi bastante significativo, sobretudo por se tratar do assunto mais diretamente ligado à figura dos representantes nos CEEs. Nos temas relacionados com o aumento do número de empresas abrangidas pela Diretiva (extensão da cobertura), os representantes anglo-irlandeses mostraram-se marcadamente mais favoráveis do que os seus colegas da Europa continental. Este facto é consistente com a maior satisfação demonstrada pelos mesmos sobre as atuais práticas dos CEEs. Também os representantes de empresas com sede em países anglo-saxónicos expressam um maior apoio do que os seus colegas de empresas com sede no continente. Dada a extensão da insatisfação com a qualidade da informação fornecida e com os procedimentos de consulta dos CEEs, não surpreende o facto de haver um forte apoio (em especial aos representantes anglo-irlandeses) a cada uma das três medidas para melhorar a qualidade da prática dos CEEs.

As medidas tendentes a melhorar a formação dos representantes dos CEEs foram também generalizadamente defendidas. A questão da "formação sobre direito do trabalho e relações laborais noutros Estados-Membros" constituiu uma prioridade para 52,9\% dos inquiridos. Muitos apontaram a falta de compreensão dos sistemas legal e laboral de outros países 
como uma falha para o desenvolvimento dos CEEs. Por outro lado, as barreiras colocadas pela língua ao nível da compreensão das reuniões foram igualmente um aspeto que, na opinião de 34,9\% dos representantes, deveria melhorar. A possibilidade de inclusão de um "papel formal para os sindicatos" na nova Diretiva dos CEE revelou-se uma expectativa partilhada pela maioria dos inquiridos e foi o único aspeto processual mais fortemente valorizado pelos representantes da Europa continental do que pelos seus colegas anglo-irlandeses.

O segundo estudo de Jeremy Waddington (2006a) partiu igualmente de um inquérito (aplicado em 2005) a representantes de trabalhadores em empresas cujos CEEs são coordenadas por seis Federações Sindicais Europeias (FSEs). O inquérito foi distribuído a 2.392 representantes de CEEs de 196 empresas e obteve um índice de respostas de 19,8\%. O inquérito foi aplicado em 24 países, 84\% dos respondentes eram homens, com uma média de idades de 50 anos e maioritariamente representantes dos trabalhadores há 15 anos. ${ }^{20}$

A posição da CES, que desde 1999 vinha a fazer pressão sobre a Comissão Europeia para a revisão da Diretiva, em parte veio a ser sustentada pelos resultados deste inquérito de 2005. O artigo $2 .^{\circ}$ da velha Diretiva determinava que a direção da empresa devia informar e consultar o CEE sobre um conjunto de assuntos relacionados com a performance e estratégia da empresa. Em princípio, a grande maioria dos acordos assinados adotou os termos constantes do artigo $2 .^{\circ}$. Menos de $1 / 3$ dos representantes dos CEEs inquiridos considerou ser "útil a informação e consulta" de todos os itens incluídos no artigo $2 .^{\circ}$. De facto, mais de $40 \%$ afirmou que itens como "mudanças nas condições de trabalho", "reorganização das linhas de produção" e "nova política tecnológica” não apareceram na agenda dos CEEs. Com uma média de quatro participações em reuniões plenárias de CEEs por cada inquirido, fica claro que estes temas não têm constado das reuniões. Alguns representantes de CEEs afirmaram que em

${ }^{20}$ Este perfil sociográfico dos respondentes tendencialmente do sexo masculino, "maduros" e a trabalharem há um tempo considerável na empresa é muito semelhante ao que Costa e Araújo (2009: 102-114) encontraram ao inquirirem os representantes portugueses em CEEs. 
termos de informação os assuntos incluídos correspondem, grosso modo, ao que constava no artigo $2 .^{\circ}$ da Diretiva. Contudo, a consulta sobre esses mesmos temas ficou aquém ou simplesmente não se realizou. Apenas o tópico constante nas agendas sindicais sobre "saúde e segurança" foi indicado por mais de metade dos respondentes como "informação útil". Isto serviu para mostrar que os representantes dos CEEs não têm conseguido alargar a agenda das reuniões dos CEEs para além daquilo que se encontra formalmente instituído. De um modo geral, apenas $1,7 \%$ dos representantes classificaram o CEE de "muito eficaz" meio de influenciar as decisões da direção, em contraste com $16,9 \%$ que afirmaram ser os CEE "nada eficazes" nesse papel.

$O$ inquérito mostrou ainda que menos de $1 / 4$ dos representantes foi informado de situações de reestruturação antes da direção finalizar a decisão e que apenas $20 \%$ foram consultados. Ou seja, cerca de $75 \%$ dos representantes de trabalhadores em CEEs ou foram informados pela direção da empresa sobre processos de reestruturação depois da decisão já estar tomada ou não foram sequer informados. E mais de $80 \%$ dos representantes em CEEs estiveram na mesma situação em relação à consulta $^{21}$. Estes factos mostram claramente as escassas oportunidades que os CEEs têm para influenciar prematuramente as decisões relativas à reestruturação das empresas.

A CES, com o apoio das FSEs, apresentou o seu próprio programa para a revisão da Diretiva antes da sua reformulação. Inquiridos sobre os pontos constantes desse programa, os representantes dos CEEs mostraram-se, na sua esmagadora maioria, favoráveis à revisão. Assim, do leque de questões a incluir na revisão da Diretiva dos CEEs, todos os representantes afirmaram "concordar" ou "concordar plenamente" nos seguintes termos (Waddington, 2006a: 43-44):

\footnotetext{
${ }^{21}$ Ao analisar 41 CEEs de multinacionais com sede em França, Alemanha, Itália, Suécia e Reino Unido, dos setores da metalomecânica, serviços financeiros, alimentação e bebidas e farmacêutico, Weiler (2004) constatou precisamente a ineficácia da consulta. Com efeito, a maioria dos representantes dos trabalhadores entrevistados considera que apenas é envolvida em processos de decisão quando as decisões já foram tomadas, ou seja, é muito rara a consulta em tempo útil. Veja-se igualmente as conclusões semelhantes a que chegou Stoop (2002: 23-24), Vallejo e White (2002: 41) ou Telljohann (2007: 152).
} 
1. Consulta antes das decisões serem implementadas $\quad 96 \%$

2. Direitos específicos em casos de fusão ou concentração $94 \%$

3. Formação para os representantes dos CEEs 93\%

4. Estabelecer limites temporais para a comunicação da informação $\quad 89 \%$

5. Direitos de negociação e de co-gestão $\quad 89 \%$

6. Estabelecer limites temporais para a consulta $\quad 87 \%$

7. Mais reuniões fora dos encontros formais dos representantes dos CEEs 85\%

8. Informação sobre um leque mais alargado de questões $\quad 81 \%$

9. Ajuda na compreensão da informação prestada pela direção $\quad 79 \%$

10. Alargar a Diretiva a mais empresas $\quad 74 \%$

11. Dar garantias aos sindicatos $\quad 73 \%$

12. Alargar a Diretiva a joint ventures e franchises $\quad 72 \%$

13. Garantir um lugar para a representação sindical nos CEEs $\quad 70 \%$

14. Representação segundo o género nos CEEs $\quad 51 \%$

O inquérito mostrou que os representantes dos CEEs têm um conjunto de prioridades a incluir na revisão da Diretiva, nomeadamente a "consulta antes das decisões operacionais da direção estarem tomadas e implementadas", "direitos específicos para os CEEs em casos de fusões ou concentrações" e "limites temporais definidos na comunicação da informação pela direção". Quando olhamos para as áreas de "alargamento" da Diretiva, verificou-se um apoio significativo dos representantes à ideia da introdução de direitos de "negociação/co-gestão" que engrossem os direitos de informação e consulta. As estimativas mostraram que 65 CEEs negociaram acordos transnacionais com a direção, número que tem vindo a aumentar desde 2000. Este facto revela que a introdução de direitos de negociação apenas vem consolidar aquilo que já é uma prática de muitos CEEs.

Em suma, os estudos feitos em diversos países, mesmo naqueles onde a tradição de representação coletiva dos trabalhadores é débil, como os Estados Unidos da América, mostram um amplo apoio dos trabalhadores a medidas que melhorem essa representação coletiva. Os CEEs podem ajudar a preencher esta necessidade, tanto mais que os representantes dos trabalhadores nos CEEs consideram útil o tipo de informação que 
ali recebem, ainda que tenham a expectativa de poder vir a ter um papel de maior relevo no futuro em todo este processo. Assim sendo, a criação de mais CEEs e o alargamento dos seus direitos e da sua capacidade de intervenção poderão ter um impacto bastante positivo no incremento do bem-estar social dos trabalhadores. Essa é a convicção de S. Vitols (2009: 19) que, tendo por referência o modelo alemão, assinala que a produtividade é $30 \%$ maior em empresas com conselhos de empresa face às que não possuem estes órgãos.

\subsubsection{A aproximação de posições entre parceiros sociais europeus}

Contrariamente à CES, a visão das organizações de empregadores europeus sobre a necessidade de revisão da Diretiva dos CEE foi, como seria de esperar, muito menos entusiasta para não dizer crítica. Somente em 2007 os CEEs foram reconhecidos como instrumentos úteis. Em geral, quase até ao início de 2008, a atitude das organizações de empregadores sobre a necessidade de revisão da Diretiva foi quase sempre negativa e crítica, "não necessária, nem desejável”, devendo antes a Comissão preocupar-se com o alargamento da UE e a integração de representantes dos novos Estados-Membros nos CEEs já existentes. Em 2006, os empregadores europeus afirmavam, entre outras coisas, que "o potencial dos CEE não será aumentado modificando a Diretiva dos CEE ou alargando o seu alcance. As partes envolvidas ao nível da empresa devem poder por si adaptar os CEEs existentes aos novos desenvolvimentos do mercado e à globalização. Um enquadramento flexível é desejável e não mais provisões legislativas restritivas" (Jagodzinski, 2009: 118).

Apesar das posições díspares dos parceiros sociais europeus, a Comissão marcaria para 2008 a revisão da Diretiva, publicando em fevereiro desse ano um comunicado que abria a segunda fase de consulta sobre a revisão da Diretiva dos CEEs. A necessidade de adequação da legislação existente à "renovada estratégia de Lisboa" e a "necessidade de adaptar a legislação dos CEEs às novas realidades económicas e sociais, à luz do aumento do número e da escala das operações de reestruturação trans- 
nacionais", foram alguns dos motivos invocados (Jagodzinski, 2009: 120). Em 29 de agosto de 2008 os parceiros sociais europeus apresentaram um documento conjunto (Joint Advice to the Council) onde se destacam alguns dos seguintes pontos: melhorar a definição dos termos informação e consulta; reconhecer o direito dos representantes de organizações sindicais comunitárias competentes de integrar as negociações para a criação de CEEs no âmbito do Grupo Especial de Negociação (GEN); garantir formação adequada aos membros dos CEEs e aos elementos do GEN sem perda de salário; informar e/ou consultar em simultâneo os CEEs e as organizações nacionais de representação de trabalhadores em situações de mudanças substanciais na organização do trabalho; manter o status excecional dos acordos assinados antes da Diretiva dos CEE (chamados acordos artigo $13 .^{\circ}$ ) na revisão da Diretiva.

Esse documento conjunto dos parceiros sociais constituiu um importante contributo para a reformulação da Diretiva, apesar dos pontos acordados serem um pequeno compromisso entre os seus assinantes.

Em síntese, nos últimos anos, como recorda Peter Kerckhofs (2010: 399-400), uma série de desenvolvimentos levaram a que a Diretiva dos CEEs tivesse que ser reformulada. Entre os fatores para essa reformulação contam-se: i) os casos julgados em tribunal relativos a $\mathrm{CEEs}^{22}$, que vieram mostrar a necessidade de integrar salvaguardas adicionais que garantissem uma maior efetividade dos direitos de informação e consulta enunciados na Diretiva de 1994; ii) o alargamento da UE, a inclusão do Reino Unido e a extensão da Diretiva dos CEEs aos países que fazem parte do EEE23 alargou o seu âmbito geográfico de 11 para 30 países e fez aumentar as expectativas em torno da aplicação da Diretiva; iii) a evolução da posição dos sindicatos e das organizações patronais sobre os CEEs à medida que o número de CEEs durante os anos 90 foi crescendo. Os desenvolvimentos no funcionamento dos CEEs contribuíram para que se criassem

22 Para uma análise de vários casos julgados em tribunal e que dão testemunho de como as dificuldades que se têm vindo a colocar ao exercício pleno das funções dos CEEs podem e devem ser resolvidas com a ajuda da jurisprudência, cf. Bercusson (2008).

23 Recorde-se que o EEE inclui os Estados-Membros da União Europeia, bem, como a Islândia, Noruega e o Liechtenstein. 
redes entre estas estruturas e as estruturas nacionais de representação dos trabalhadores e de sindicatos, tanto ao nível nacional como europeu. Com o passar do tempo também as organizações patronais mudaram as suas posições sobre os CEEs e sobre o seu enquadramento legal.

Em forma de antecipação à secção seguinte, se atentarmos no ponto 7 do preâmbulo da nova Diretiva podemos observar uma explanação das razões de fundo para reformular a Diretiva 94/45/CE: "Afigura-se necessário modernizar a legislação comunitária em matéria de informação e de consulta transnacional dos trabalhadores, no intuito de garantir a efetividade dos direitos de informação e de consulta transnacional dos trabalhadores, aumentar a percentagem de conselhos de empresa europeus já instituídos, permitindo simultaneamente que os acordos existentes continuem a funcionar, resolver os problemas constatados na aplicação prática da Diretiva 94/45/CE e resolver a questão da insegurança jurídica decorrente de algumas das suas disposições ou da sua falta e melhorar a articulação dos instrumentos legislativos comunitários em matéria de informação e consulta dos trabalhadores".

\subsection{O que é neo na Diretiva 2009/38/CE?}

Até aqui ficaram expostos os principais focos de insatisfação sindical/ laboral quanto ao funcionamento da velha Diretiva. Atente-se seguidamente numa síntese das principais alterações de fundo trazidas pela Diretiva 2009/38/CE.

\subsubsection{Algumas alterações de fundo}

Menos de um ano depois do lançamento do processo legislativo (fevereiro de 2008) a Diretiva remodelada ("reformulada" 24 é o termo utilizado

${ }^{24}$ A Diretiva 2009/38/CE é uma Diretiva reformulada. Tal significa que a velha Diretiva e as alterações introduzidas pela nova Diretiva estão reunidas num único instrumento. Uma 
na Diretiva) foi adotada pelo Conselho da UE em 17 de dezembro de 2008. Algumas das alterações contempladas podem aqui ser elencadas ${ }^{25}$. Desde logo, duas:

a) Por um lado, foi acrescentada uma explicação ao ponto 16 do preâmbulo da nova Diretiva, mostrando como interpretar a noção chave de "transnacionalidade" da competência dos CEE e o direito que os próprios representantes dos trabalhadores têm ao seu acesso: "são consideradas transnacionais as questões que dizem respeito ao conjunto da empresa ou do grupo ou, pelo menos, dois Estados-Membros. Tal inclui as questões que, independentemente do número de Estados-Membros em causa, são importantes para os trabalhadores europeus em razão do alcance dos seus efeitos potenciais ou que envolvem transferências de atividades entre Estados-Membros";

b) Por outro lado, foi acrescentado o ponto 36 no preâmbulo da nova Diretiva, que explicita as sanções a aplicar, em caso de violação das obrigações presentes na Diretiva, assim como é igualmente garantido, nos termos do artigo $10 .^{\circ}$, o papel de proteção dos representantes dos trabalhadores: por exemplo, dotando os membros dos CEEs "dos meios necessários para aplicar os direitos decorrentes da Diretiva" (artigo 10. n. ${ }^{\circ}$ 1) ou mesmo prevendo que os membros do GEN e do CEE beneficiem "de formações sem perda de remuneração" (artigo 10. ${ }^{\circ}$ n. ${ }^{\circ} 4$ ).

Em comparação com a Diretiva 94/45/CE, a Diretiva 2009/38/CE apresenta, assim, um conjunto de progressos:

1. O ponto 7 do preâmbulo da Diretiva esclarece os principais motivos que estiveram na origem da sua reformulação. Este ponto constitui uma espécie de mea culpa do legislador europeu quanto à necessidade de melhorar o quadro normativo anterior;

vez que o prazo final para a transposição da nova Diretiva para o(s) direito(s) nacional(ais) foi o de 5.06.2011, a velha Diretiva deixou tecnicamente de existir, o que significa que há apenas uma Diretiva a produzir efeitos legais. O novo artigo $18 .^{\circ}$ da Diretiva 2009/38/CE faz um elenco das principais alterações (de artigos e alíneas) comparativamente à versão da Diretiva 94/45/CE, sendo a sua aplicabilidade válida desde 6.06.2011 (Picard, 2010: 20).

25 Como já se disse, para uma análise mais fina, cf. Jagodzinski, (2009), Blainpain (2009), ETUC (2010), Dorssement e Blanke (orgs., 2010) ou Picard (2010), Waddington (2011: 180-210). 
2. As principais competências e razões de ser dos CEE - a informação e a consulta - são confirmadas e ampliadas pela nova Diretiva. No seu conjunto, oito alíneas (pontos) e o artigo $2 .^{\circ}$ fazem referência a estes conceitos chave realçando, em particular, a natureza atempada da informação e da consulta assim como a necessidade de garantir que as mesmas não limitam ou retardam o processo de tomada de decisão nas empresas. Nas disposições supletivas (Anexo I) foi introduzida uma diferenciação entre as matérias sobre as quais os CEEs têm o direito a ser informados e aquelas que exigem a sua consulta;

3. Outro elemento novo da Diretiva é a obrigatoriedade da direção central da empresa de dimensão comunitária, bem como das administrações locais, de transmitirem a informação necessária à abertura de negociações para a criação de CEE (em especial informação relativa à estrutura da empresa ou grupo e dos seus trabalhadores);

4. Um outro dado novo foi também introduzido ao nível do GEN, que agora tem um número mínimo de 10 elementos (i.e., um elemento por cada $10 \%$ ou fração da força de trabalho empregada num Estado-Membro). Em reconhecimento do papel das organizações sindicais e/ou organizações representativas dos trabalhadores foi introduzida a obrigatoriedade de serem informadas as estruturas sindicais europeias competentes aquando das negociações para a criação de CEE. Para além disso, os representantes sindicais também poderão, à luz da nova Diretiva, ser convocados enquanto peritos do GEN;

5. O parágrafo 4 do artigo $5 .^{\circ}$ introduz mais um elemento novo que é a possibilidade do GEN poder reunir-se antes e depois de qualquer encontro com a direção central, sem a presença de representantes dessa direção. Esta possibilidade permitirá ao CEE discutir mais abertamente os conteúdos das reuniões plenárias e concertar estratégias e planos de ação com base nas informações recebidas da direção;

6. No que respeita ao conteúdo dos acordos, novos elementos foram também introduzidos: a representação dos trabalhadores no CEE deve ser, na medida do possível, uma "representação equilibrada dos trabalhadores segundo as atividades, as categorias profissionais e o sexo" (artigo 6. ${ }^{\circ}$, n. $^{\circ}$ 2, al. b). Por outro lado, a nova Diretiva deverá incluir obrigatoriamente 
cláusulas contratuais sobre modalidades de articulação entre a informação e a consulta do CEE e as instâncias nacionais de representação dos trabalhadores. Deve também constar obrigatoriamente do acordo final de um CEE "a data de entrada em vigor do acordo e a sua duração, as modalidades segundo as quais o acordo pode ser alterado ou denunciado, bem como os casos em que deve ser renegociado", incluindo quando ocorrem alterações na estrutura da empresa de dimensão comunitária ou grupo (artigo 6..$^{\circ}$, al. g);

7. As competências dos CEEs não só estão melhor definidas na nova Diretiva (artigo 1. ${ }^{\circ},{ }^{\circ}{ }^{\circ} 2$ ), como são alargadas (artigo 12. ${ }^{\circ}$, n. ${ }^{\circ} 1$ ) à área da representação coletiva dos interesses dos trabalhadores, garantindo no futuro melhor acesso e melhores meios de defesa dos seus direitos em termos legais.

8. As novas competências que advêm da reformulação da Diretiva obrigam as direções das empresas a providenciarem os meios necessários ao CEE e aos seus membros. Esta regra, vista em conjunto com o artigo $10 .^{\circ},{ }^{\circ}{ }^{\circ} 2$, assim como quando combinada com a obrigatoriedade de informação dos trabalhadores nas instâncias nacionais que os representam, constitui uma garantia e um reforço dos instrumentos de ação dos CEEs.

\subsubsection{O timing da informação e consulta e a relação nacional/ transnacional}

Um dos principais objetivos da reformulação da Diretiva 94/45/CE foi assegurar a eficácia dos direitos de informação e consulta transnacionais dos trabalhadores, clarificando o momento, a forma e o conteúdo dos procedimentos em questão. O ponto 21 do preâmbulo da nova Diretiva permite constatar isso mesmo: "é conveniente clarificar as noções de informação e de consulta dos trabalhadores, de harmonia com as diretivas mais recentes sobre esta matéria e que se aplicam num quadro nacional, com o triplo objetivo de reforçar a efetividade do nível transnacional de diálogo, permitir uma articulação adequada entre os níveis nacional e transnacional desse diálogo e garantir a segurança jurídica necessária na aplicação da presente diretiva”. 
Sequencialmente, nos pontos 22 e 23 do preâmbulo da Diretiva 2009/38/CE, é apresentada uma clarificação dos conceitos de informação e consulta. Em relação à oportunidade (momento) para a informação e consulta dois aspetos tornam-se claros nessas cláusulas:

O objetivo da informação é o de permitir aos representantes dos trabalhadores "um exame adequado (...) sem retardar o processo de tomada de decisão nas empresas (ponto 22 do preâmbulo). Para se atingir este objetivo, a informação sobre medidas de reestruturação transnacionais tem que ser fornecida o mais cedo possível, para que o CEE tenha a possibilidade de elaborar as suas próprias posições. A intenção expressa na Diretiva de não atrasar o processo de tomada de decisão implica obrigações tanto para o CEE como para a administração da empresa. O CEE deve comprometer-se a não fazer uso dos seus direitos para atrasar o processo. A administração tem que ter em atenção, desde logo no planeamento do processo de decisão, o tempo que é necessário para colocar em marcha os intensivos procedimentos de informação e consulta.

O objetivo da consulta, por sua vez, consiste em que por meio desta se permita a expressão de uma opinião (dos representantes dos trabalhadores) "que será útil no processo de tomada de decisão" (ponto 23 do preâmbulo). Esta é uma afirmação clara uma vez que, em contraste com o ponto 20 do preâmbulo da Diretiva original, a consulta depois da decisão tomada já não interessa. A função do CEE não deve limitar-se ao acompanhamento do processo de implementação das medidas de reestruturação mas também ter influência na sua decisão. Além disso, a opinião do CEE deverá ser útil em todo o processo de tomada de decisão. Assim, não é de todo suficiente consultar o CEE no último momento antes da tomada de decisão. A intenção é, ante tempus, a de integrar as críticas, ideias e sugestões dadas pelo CEE no desenvolvimento das propostas da administração para a decisão final.

Como recordam Blanke e Rose (2010: 342-343), o legislador europeu resolveu não incluir estes novos conceitos de informação e consulta nas disposições supletivas do anexo da Diretiva reformulada. Antes pelo contrário, as novas definições de informação e consulta foram acrescentadas 
ao artigo $2 .^{\circ}$ da nova Diretiva. ${ }^{26}$. Neste reforço da centralidade concedida às noções de informação e consulta percebe-se que a questão do timing é nuclear, até porque a prática da informação e da consulta em tempo útil foi um dos pretextos mais fortes para a reformulação da Diretiva. A Diretiva 2009/38/CE estipula claramente que as futuras consultas deverão ocorrer antes das decisões tomadas pela administração.

Na velha Diretiva não estava contemplada qualquer regra sobre o momento exato no tempo para se dar início ao processo de informação e consulta entre as normas legais da Diretiva. Além disso, apresentava-se uma afirmação vaga que apontava para o facto de a informação e consulta deverem ocorrer "o mais rapidamente possível" depois "de certas decisões" que não se encontravam claramente definidas e não existia nenhuma afirmação que se reportasse ao facto de o CEE dever exercer influência sobre o processo de decisão da empresa (Blanke e Rose, 2010: 332). Na nova Diretiva, ao invés, sustenta-se que a informação deverá ser dada tão cedo quanto possível de modo a que os representantes dos trabalhadores possam exercer influência nos processos de tomada de decisão transnacionais. Isto significa que o ato de informar deve ser iniciado antes de começar a implementação da decisão, isto é, no próprio processo de preparação dessa decisão. Mesmo não estando previstos direitos de co-gestão, a informação e consulta estão agora orientadas para um objetivo bem definido que é a participação efetiva dos trabalhadores no desenvolvimento das suas empresas (Blanke e Rose, 2010: 352-353).

Além das implicações decorrentes do processo de tomada de decisão por parte das administrações, a questão do tempo correto para a informação e consulta deve ainda articular-se com a relação entre os órgãos nacionais de representação dos trabalhadores e os órgãos representativos dos trabalhadores de nível europeu (em particular os CEEs). Com efeito, uma ligação entre os níveis transnacional e nacional de informação e consulta é vista como necessária na Diretiva 2009/38/CE, em particular no que diz respeito à coordenação cronológica de quem deve ser informado

${ }^{26}$ Atente-se com efeito no artigo $2 .^{\circ}, \S 1 \mathrm{f}$ : definição de "informação"; e ainda no artigo $2 .{ }^{\circ} \S 1 \mathrm{~g}$ : definição de "consulta". 
e consultado em primeiro lugar: o CEE ou os representantes nacionais dos trabalhadores. Como lembram Blanke e Rose (2010: 328-329), alguns conselhos de empresa, como os comités d'entreprise franceses insistem para que o CEE seja informado e consultado em primeira-mão, antes mesmo do seu próprio processo de consulta se iniciar. Pelo contrário, os conselhos de empresa (betriebsräte) alemães partem do princípio de que lhes deve ser dada a informação em primeira-mão e a oportunidade para tomarem posição sobre essa informação numa fase prematura das medidas de reestruturação planeadas, ou seja, muito antes de qualquer consulta ao CEE.

Antes da nova Diretiva 2009/38/CE não existiam regras nas legislações europeia ou nacionais que determinassem que em casos de competências de consulta concorrentes ao nível europeu ou nacional e local quais é que se sobreporiam. A partir desta Diretiva passam a estar contempladas regras sobre a coordenação dos direitos dos CEEs e dos órgãos nacionais de representação dos trabalhadores, no artigo $12 .^{\circ}$, ainda que o texto comunitário se limite a encorajar (artigo $\left.12 .^{\circ}, \S 2\right)$ as partes na negociação dos acordos de CEEs na empresa ou grupo de empresas a chegarem a um compromisso e a encontrarem soluções adequadas.

Adicionalmente, é dito que as legislações nacionais devem criar disposições sobre a coordenação entre os dois níveis: "Na falta de tais modalidades definidas por acordo, os Estados-Membros devem prever que o procedimento de informação e consulta tenha lugar no Conselho de Empresa Europeu, bem como nas instâncias nacionais de representação dos trabalhadores, sempre que estejam previstas decisões suscetíveis de provocar alterações importantes na organização do trabalho ou nos contratos de trabalho.” (artigo 12. ${ }^{\circ}, \S 3$ ).

Em primeiro lugar, as regulamentações dos Estados-Membros só serão válidas nos casos em que "estejam previstas decisões suscetíveis de provocar alterações importantes na organização do trabalho ou nos contratos de trabalho". Em segundo lugar, as regulamentações prévias dos Estados-Membros deverão apenas assegurar que ambos os processos de informação e consulta irão ser "igualmente" conduzidos. O artigo 12. ${ }^{\circ}, \S 3$ nada diz sobre de que forma é que os dois processos devem estar ligados. 
O ponto 37 do preâmbulo da Diretiva 2009/38/CE é, no entanto, esclarecedor neste ponto: "Na falta de acordo sobre esta matéria e sempre que se preveem decisões suscetíveis de desencadear mudanças substanciais a nível da organização do trabalho ou dos contratos de trabalho, o processo deve ser conduzido concomitantemente ao nível nacional e europeu, respeitando as competências e as esferas de intervenção respetivas das instâncias de representação dos trabalhadores. A emissão de um parecer pelo CEE não deverá afetar a capacidade da direção central na condução das consultas necessárias, respeitando os prazos previstos pelas legislações e/ou as práticas nacionais. As legislações e/ou as práticas nacionais deverão eventualmente ser adaptadas para que o CEE possa, se necessário, ser informado antes ou ao mesmo tempo que as instâncias nacionais de representação dos trabalhadores, sem reduzir o nível geral de proteção dos trabalhadores".

Esta última frase clarifica o seguinte: em futuros acordos ou regulamentações relacionadas com as ligações entre a informação e consulta dos CEEs e as organizações nacionais de representação dos trabalhadores (ORTs) deverão constar disposições relativas à coordenação temporal. Em resumo, a questão da coordenação entre a participação dos trabalhadores ao nível nacional e europeia encontra-se prevista pela primeira vez na legislação comunitária, ainda que não tenha sido prevista uma ordem cronológica específica. Nas disposições obrigatórias da nova Diretiva não há uma definição precisa sobre qual deve ser a ordem temporal para a informação e consulta nos diferentes níveis. Somente no ponto 37 do preâmbulo, como vimos, é que o legislador europeu indica uma certa preferência pela interpretação de que o CEE deve ter prioridade ou pelo menos ser informado ao mesmo tempo que os órgãos nacionais competentes. Nas disposições obrigatórias da Diretiva aquilo que fica estipulado é que a coordenação temporal deve ficar definida em cada acordo negociado em concreto. Só as partes interessadas em cada empresa ou conjunto de empresas poderão entre si desenvolver uma determinada coordenação cronológica nos vários níveis de participação de modo a que esta seja o mais eficiente possível. 


\subsubsection{Em busca de CEEs enquanto "atores europeus"}

Pegando no argumento com que findou a secção anterior, valerá a pena acrescentar que, além dos argumentos jurídicos, são necessários argumentos pragmáticos. Ou seja, é provável que a relação nacional/transnacional pensada de modo a garantir em tempo útil o acesso à informação e consulta dos trabalhadores será tanto mais facilitada quanto for "saudável" a relação entre CEEs e ORTs. Mas a questão prioritária talvez seja mesmo que haja informação e consulta em tempo útil e de forma significativa. Se esse passo for garantido na prática quotidiana do funcionamento dos CEEs e se, a par dele, os "canais de comunicação" entre representantes de CEEs e representantes de ORTs estiverem desimpedidos, certamente que isso será um passo decisivo para reforçar o próprio "estatuto transnacional" dos CEEs.

Ora, é sobre o papel dos CEEs enquanto "ator europeu" que melhor se poderá também perceber a mais-valia dos CEEs. Na opinião de J. Lamers (2010), a Diretiva 2009/38/CE destaca precisamente o reforço do papel europeu dos CEEs. Por um lado, limita a competência dos CEEs às matérias transnacionais. Por outro lado, liga os níveis de informação e consulta nacionais e europeus. O papel europeu dos CEEs também é reforçado na nova Diretiva uma vez que esta lhes atribui a competência de representarem coletivamente os interesses dos trabalhadores a nível europeu. Os CEEs obtêm o direito legal à formação dando aos representantes a possibilidade de desempenharem mais eficazmente as suas atribuições num contexto internacional.

De igual modo, recorde-se que o ponto 16 do preâmbulo de Diretiva restringe a competência dos CEEs às questões transnacionais como forma de excluir a possibilidade de ali serem tratados assuntos de natureza local. Assim, qualquer matéria relevante para a força de trabalho de uma empresa na Europa ou qualquer transferência de atividade são consideradas matérias transnacionais, independentemente do número de países envolvidos. Como resultado, o âmbito da competência dos CEEs irá "abraçar" o das comissões de trabalhadores locais e o dos sindicatos. A Diretiva reformulada pretende ligar os procedimentos de informação 
e consulta dos CEEs com aqueles que ocorrem ao nível dos órgãos representativos dos trabalhadores locais. O resultado será o aumento da cooperação entre esses órgãos locais e os CEEs, quando estiverem em causa matérias de importância crucial para a força de trabalho ou em situações de transferências de atividade dentro da UE.

O reforço da colaboração e confiança entre administrações de empresas e representantes de trabalhadores constitui, em bom rigor, um fator igualmente decisivo para o reforço do papel europeu dos CEEs. Na ótica das administrações das empresas, no plano europeu o valor acrescentado dos CEEs significa: incentivo à internacionalização, plataforma europeia para a comunicação, veículo para a informação e comunicação, fertilização cruzada internacional, desenvolvimento de uma dimensão europeia, ajuda ao processo de decisão. Por sua vez, na opinião dos representantes dos trabalhadores nesse mesmo plano europeu o valor acrescentado dos CEEs significa: acesso ao mais alto nível da instituição, informação ao nível do grupo, consulta com colegas de outros países, fertilização cruzada internacional, visões comuns e valores, condução e avaliação através do diálogo europeu e desenvolvimento da dimensão europeia (Lamers, 2010: 387).

Para Peter Kerckhofs (2010: 399), o que está em jogo com a nova Diretiva é, em grande medida, a efetividade dos próprios CEEs. E isso passa por considerar 3 vertentes de análise: a facilitação das condições para a criação de novos CEEs; o apoio aos CEEs já existentes, de modo a dotá-los de maior qualidade; e o envolvimento dos parceiros sociais na criação de CEEs.

I. Relativamente ao estabelecimento de condições para a criação de novos CEEs, esta parece indissociável da vontade das partes (a tal confiança entre as partes de que se falava acima é, na verdade, decisiva a esse respeito). Perante o elevado número de empresas que se encontra dentro do âmbito de aplicação da Diretiva mas que não tem constituídos CEEs $^{27}$, um esforço adicional passa pela necessidade de os representantes

27 Blainpain (2009: xi) questiona-se até que ponto será possível criar novos CEEs, sobretudo em empresas com menos de 10.000 trabalhadores (onde o n. ${ }^{\circ}$ de CEEs é consi- 
dos trabalhadores convencerem as administrações das empresas onde trabalham a divulgar o âmbito e a estrutura das empresas multinacionais onde trabalham. Ao fazerem este pedido, o desejo de constituírem um CEE pode desencadear desde logo alguma oposição. Essas reservas podem desencorajar os atores envolvidos a continuar com esta fase do processo. Subsequentemente poderão ter que convencer representantes dos trabalhadores desconhecidos de outro país a participar no pedido escrito para dar início ao GEN. Ultrapassar estes desafios nesta fase preparatória é crucial para a criação dos mais de 1.000 CEEs não existentes (Kerckhofs, 2010: 403).

Com a implementação da Diretiva 2009/38/CE, o seu artigo $4 .^{\circ}, \S 4$, poderá ajudar neste processo de recolha de informação sobre o âmbito e estrutura da empresa, responsabilizando as administrações locais pela divulgação desta informação em cada local de trabalho. Mas, entretanto, a presença sindical é decisiva para desencadear a constituição de CEEs. Com efeito, se as empresas não tiverem envolvimento sindical bem cimentado nas suas operações, os sindicatos, por si próprios, pouco poderão fazer para ultrapassar estas dificuldades. Em empresas com uma presença sindical limitada as administrações poderão fazer pressão sobre aqueles que procuram dar o passo para criar um GEN.

Ainda sobre o processo de facilitação das condições para a criação de novos CEEs, Kerckhofs (2010: 404-406) distingue incentivos legais bem como regras destinadas a melhorar a capacidade de negociação dos GENs. A questão dos incentivos legais prende-se com a motivação dos atores envolvidos para perceberem a mais valia que um CEE pode representar. Se os atores estiverem decididos a avançar com a criação de um CEE, um pedido formal por escrito para dar início à constituição do GEN poderá ser negligenciável ou reduzido a uma mera formalidade. Porém, se as motivações negativas prevalecerem como fatores inibidores poderá desencadear-se o efeito contrário. Se as obrigações que decorrem

derado escasso). Em seu entender, isso explica-se pelo fraco poder efetivo dos sindicatos em apoiarem os trabalhadores no estabelecimento e funcionamento de CEEs. O facto de os sindicatos passarem a poder atuar como peritos poderá criar maiores possibilidades de reforço do número de CEEs. 
da Diretiva 2009/38/CE são causa de algum receio, elas poderiam ser evitadas se, por antecipação, se desse logo início à constituição de CEEs antes do dia 6 de junho de 2011. Se o impacto for semelhante ao que teve o artigo $13 .^{\circ}$ da Diretiva 94/45/CE, o número de CEEs poderia aumentar cerca de 50\%. Nos 12 meses anteriores ao dia 22 de setembro de 1996, o artigo $13 .^{\circ}$ terá incentivado cerca de $30 \%$ das empresas abrangidas a constituírem CEEs. Projetando esta proporção sobre as 1.471 empresas abrangidas sem CEEs, seria de esperar a constituição de mais 440 CEEs antes do dia 6 de junho de 2011. No entanto, Kerckhofs considera que seria pouco provável que o artigo $14 .^{\circ}$ da Diretiva 2009/38/CE viesse a ter um impacto tão grande, até porque as organizações sindicais europeias não estiveram envolvidas em grande número em reuniões de preparação, tanto quanto estiveram antes de 1996. A maior parte das grandes empresas e as mais internacionais já têm CEEs, o que significa que as restantes empresas abrangidas pela Diretiva sem CEEs constituídos estão longe de se comparar àquelas que, antes de 1996, também ainda não tinham CEEs.

Quanto à atuação do GEN importa reter o marco temporal de junho de 2011. Com já se disse, até 5 de junho de 2011 a criação de novos CEEs foi feita ainda ao abrigo do artigo $6 .^{\circ}$ da Diretiva 94/45/CE, sob a forma de um GEN, e com os conteúdos a serem determinados no acordo do CEE. Desde 6 de junho de 2011, cinco novas regras passaram a melhorar a capacidade de negociação dos GENs:

i) Aos países com mais de $10 \%$ da força de trabalho europeia é-lhes dado mais peso na composição dos GENs;

ii) Os representantes dos trabalhadores nos GENs terão direito a ter reuniões preparatórias e posteriores, algo que os representantes dos trabalhadores não tinham antes e depois das reuniões negociais com a administração (artigo 5. ${ }^{\circ}, \S 4$, secção 2 da Diretiva reformulada). Esta nova possibilidade permitirá aos membros do GEN estreitar a sua coesão interna ao longo do processo negocial;

iii) As FSEs deverão ser notificadas da composição do GEN e do início das negociações (artigo $5 .^{\circ}, \S 2 c$ da Diretiva reformulada). Desta forma os sindicatos poderão monitorizar até que ponto as estruturas de 
representação dos trabalhadores existentes são respeitadas na eleição ou designação dos membros do GEN, de acordo com as regras e procedimentos nacionais em vigor, tal como determina o artigo $5 .^{\circ}, \S 2 \mathrm{a} \mathrm{da}$ Diretiva reformulada;

iv) A pedido dos membros do GEN, as organizações sindicais europeias poderão delegar um perito sindical para o GEN, para ajudar e aconselhar durante as negociações (artigo $5^{\circ}$, $\S 4$ secção 3 da Diretiva reformulada). Os GENs poderão, desta forma, beneficiar da experiência de outros CEEs e das lições que outras negociações do GEN ensinaram;

v) Os membros do GEN têm direito a receber formação para melhor desempenharem o seu papel de representantes dos trabalhadores no contexto europeu (Artigo $10 .^{\circ}, \S 4$ da Diretiva reformulada). Esta oportunidade de formação poderá preparar melhor os representantes dos trabalhadores para a cooperação e para as negociações que irão ter de fazer no âmbito do GEN.

II. A segunda vertente de análise que poderá contribuir para dotar os CEEs de maior efetividade prende-se com a criação de dispositivos que melhorem a qualidade dos CEEs em funcionamento. Neste ponto, a nova Diretiva poderá produzir três categorias de impactos: impacto legal estrito, impacto moral e impacto ao nível dos processos legais (case law). O impacto legal estrito é a categoria das obrigações legais que não são contestáveis, nem deixam espaço para interpretações. A segunda categoria é formada pelas provisões que legalmente não serão obrigatórias mas que, apesar disso, são geralmente seguidas e consideradas, uma vez que os atores se sentem moralmente obrigados a segui-las. A terceira categoria, pelo contrário, abrange as obrigações legais que são objeto de contestação, por via das diferentes interpretações que poderão ter. A questão aqui é a de saber se os direitos dos atores são infringidos de tal modo que eles os possam trazer para os tribunais e, claro, também de que forma é que os tribunais poderão eventualmente alargar o impacto legal da Diretiva. As lições que se aprenderam destes processos legais estão integradas nos incentivos que ajudam ao estabelecimento de CEEs inexistentes, e parcialmente também nas definições melhoradas dos ter- 
mos informação e consulta, mas não tanto na definição das competências transnacionais atribuídas aos CEEs. ${ }^{28}$

III. A terceira vertente capaz de contribuir para uma maior efetividade dos CEEs prende-se com o envolvimento dos parceiros sociais. A adoção da nova Diretiva fez com que as organizações de trabalhadores e o patronato revissem a suas posições sobre o enquadramento legal dos CEEs. De contrárias à adoção da Diretiva dos CEEs em 1994 e à sua revisão em 2004 e 2005, a Business Europe (ex-UNICE) passou a negociar com a CES a revisão de 2008 (como se disse anteriormente). Conseguiu-se uma posição conjunta, o que demonstrou: por um lado, uma posição dos empregadores mais favorável a uma alteração do quadro legal dos CEEs; por outro lado, uma posição da esfera laboral tendente a ajustar expectativas até se chegar a uma posição conjunta. A implementação da nova Diretiva deixa, assim, em aberto a possibilidade de outros desenvolvimentos serem influenciados pelos parceiros sociais europeus.

Entretanto, a CES procedeu a uma interpretação legal da Diretiva reformulada e as FSEs $^{29}$ chegariam a um acordo sobre as recomendações para o período entre 5 de junho de 2009 e 5 de junho de 2011 (EMF et al., 2009). As organizações sindicais assumiram a nova Diretiva como a base de qualquer renegociação ou nova negociação naquele período de transição. Uma vez que as novas provisões da Diretiva tiveram o acordo dos parceiros sociais europeus, os sindicatos não veem razão para atrasar a sua integração nas negociações a decorrer ou nas renegociações, ou para limitar a sua aplicação aos CEEs já existentes. Além disso, alguns avisos foram dados aos sindicatos:

- Não alterar as definições que constam da nova Diretiva, exceto se elas formalizarem "boas práticas” que vão para além dessas definições;

28 Para uma análise mais apurada relativa ao upgrading dos CEEs existentes, cf. Kerckhofs (2010: 408-413).

29 European Metalworkers' Federation, European Mine, Chemical and Energy Workers Federation, European Trade Union Federation Textiles Clothing and Leather, Union Network International-Europa, European Federation of Public Services Union, European Federation of Food, Agriculture \& Tourism Trade Unions, European Federation of Building and Woodworkers, European Transport Workers' Federation. 
- Não aceitar limites temporais para os procedimentos de consulta, porque os procedimentos de informação e consulta deixaram de poder ser vistos como impeditivos dos processos de tomada de decisão das empresas;

- Não rejeitar nos novos acordos a possibilidade de mudanças significativas ao âmbito ou estrutura da empresa provocarem renegociações à luz da nova Diretiva.

As FSEs recomendaram que a assinatura de novos acordos de CEEs e de acordos renegociados se fizesse, se possível, depois de 6 de junho de 2011. Se, no entanto, fossem assinados acordos no período de transição, então nesse caso o entendimento seria o de que deveriam ser devidamente feitas referências à Diretiva reformulada, clarificando desde logo que esta deveria ser a referência em relação à definição de direitos e obrigações (EMF et al., 2009), tanto mais que o futuro dos CEEs se passa a guiar por esta Diretiva.

Em resumo, a Diretiva 2009/38/CE introduz melhorias na forma de percecionar o papel da informação e consulta dos trabalhadores das empresas de dimensão comunitária situadas no EEE. Em resultado de alguns diagnósticos anteriores que apontavam limitações relativas ao modo como estava salvaguardada a participação e envolvimento dos trabalhadores (o timing, a consistência e utilidade da informação e da consulta que lhes era prestada, ou o reforço da presença de peritos, de mecanismos de formação, ou da realização de reuniões foram apenas algumas das várias limitações apontadas), em geral, realça-se uma preocupação em definir com maior clareza as noções de "informação", "consulta" e "transnacional". Além disso, outras importantes alterações prendem-se com as articulações entre os vários níveis de informação e consulta dos trabalhadores, com a formação concedida aos membros dos CEEs, com a composição do GEN e do seu modo de funcionamento no que concerne aos encontros de negociação.

Ainda que porventura com uma aplicação menos consistente do princípio da autonomia das partes, ao fazer da cláusula da devolução da informação uma regra obrigatória e não uma provisão inscrita na (re) 
negociação do acordo (Lamers, 2010: 361), o facto de se garantir o direito legal à formação constituirá uma importante pré-condição para o melhor funcionamento dos CEEs num contexto internacional, conferindo-lhe assim também melhores possibilidades de reforço da condição de ator transnacional efetivo.

Os mecanismos de vigilância sobre o modus operandi dos CEEs parecem encontrar-se igualmente melhor acautelados na nova Diretiva. A este respeito vale a pena voltar ao conteúdo do ponto 36 do preâmbulo da Diretiva 2009/38/CE, nos termos do qual o apelo ao cumprimento dos preceitos da lei comunitária é um must sujeito a "sanções eficazes, dissuasivas e proporcionadas" em caso de incumprimento. Este expectável apelo ao cumprimento da lei remetia, afinal, para os trâmites associados ao processo variado de transposição da Diretiva para os ordenamentos jurídicos dos países até 5 de junho de 2011. Mas acrescentando-lhe a possibilidade de sanções, ainda que se deva admitir que será a prática da Diretiva 2009/38/CE que melhor permitirá aferir da sua eficácia e, portanto, da oportunidade ou não de tais sanções. Afinal, como se deduz de algumas das análises aqui deixadas, a Diretiva reformulada veio expandir a base legal de funcionamento dos CEEs, tornando-a mais sólida. No entanto, estamos diante de um quadro que necessita ser comprovado por soluções práticas efetivas e por isso é preciso, em última análise, estar atento ao comportamento dos CEEs em ação. 
(Página deixada propositadamente em branco) 


\section{CA P ÍTULO 2}

\section{ESTUDOS, TIPOLOGIAS " BOAS PRÁTICAS” SOBRE CONSELHOS DE EMPRESA EUROPEUS}

Em complemento ao capítulo anterior, são agora analisadas várias perspetivas que têm sido valorizadas no tratamento dos CEEs. Em simultâneo, recuperam-se algumas propostas de tipologias para classificar a atuação dos CEEs, bem como exemplos de "boas práticas" que, no fundo, servem para "pôr à prova" as tipologias e a efetividade dos CEEs.

\section{Estudos e temas de investigação sobre os CEEs}

Como foi referido na introdução deste trabalho, têm sido valorizados diferentes tipos de abordagens sobre os CEEs: as tradições de diálogo social nacional e a forma com os CEEs beneficiam de um aquis instalado; a expressão quantitativa dos CEEs em geral; a relevância setorial dos CEEs; as análises dos acordos voluntários e dos acordos formais de CEEs de forma comparada no quadro europeu; o papel das tipologias de CEEs e a sua eficácia efetiva; o valor da comunicação inter e intra-CEEs; o modo como a consulta e a informação funcionam no papel e na prática; o timing da informação e consulta; as experiências de representantes de trabalhadores; os obstáculos que limitam a constituição e o funcionamento dos CEEs; a visão das entidades empregadoras; o perfil sociográfico dos representantes em CEEs; os processos de melhoria (revisão, reformulação) da lei comunitária; o papel dos sindicatos/federações sindicais europeias nos CEEs; os CEEs e a identidade laboral transnacional, etc. 
Não cabe aqui fazer uma análise minuciosa de tais tópicos, mas apenas realçar alguns planos de análise transversal e até multidisciplinar. ${ }^{30}$

\subsection{CEEs e níveis de análise}

Com recorda Platzer (2009: 48), o debate académico sobre os CEEs tem permitido contrapor dois argumentos opostos. Por um lado, os "pessimistas" veem os CEEs como sendo "nem europeus, nem conselhos de empresa", mas antes como instrumentos da representação de interesses nacionais ou como extensões de diferentes estruturas nacionais de informação e consulta dos trabalhadores (Streeck, 1998; Miller, 1999; Miller e Stirling 1998) ou mesmo como veículos para a competição inter-estatal entre regimes laborais (Hancké, 2000). Por outro lado, os "otimistas", veem os CEEs como arranjos institucionais que possibilitam o desenvolvimento de identidades coletivas e ações transnacionais (Marginson e Sisson, 1996; Whittall, Knuden, Huijgen, 200731) e como instrumentos para contrabalançar a competição interna nas empresas e para articular posições entre trabalhadores a nível transnacional. Estas posições extremadas resultam, em grande medida, da aplicação de grelhas teóricas e normativas divergentes ao estudo dos CEEs. Mas, ao mesmo tempo, estas visões teóricas opostas são também o sinal de que os CEEs são atravessados por diferentes cruzamentos e níveis de análise com valorizações diferenciadas.

30 As análises sobre os CEEs estão repartidas por centenas de artigos publicados em revistas, livros ou relatórios de projetos de investigação produzidos ao longo de cerca de 20 anos. De entre os trabalhos de maior volume - livros, monografias, relatórios ou números temáticos de revistas - vale a pena, entre outros, destacar os de Bonneton et al. (1996), Transfer vol. 1 (2) (1995); vol. 5 (3) (1999), Costa (1996), Leite et al. (1996), Blainpain (1998; 2009), Lecher et al. (orgs., 1999; 2001; 2002), Marginson et al. (1998), Carley (2001), European Journal of Industrial Relations, Vol. 6 (1) (2000), European Works Councils Bulletin (publicado até 2006), Kerckhofs (2002; 2006), Kerckhofs e Pas (2006), Fitzgerald e Stirling (2004), Weiler (2004), Telljohann (org.) (2005b), Costa e Araújo (2007b; 2009), Whittall, Knuden e Huijgen (orgs.) (2007), Hertwig, Pries e Rampeltshammer (orgs.) (2009), Dorssement e Blanke (2010) e Waddington (2011).

31 Assinale-se, no entanto, que os autores que colaboram neste livro organizado por Whittall, Knuden, Huijgen realçam as dificuldades em construir uma identidade laboral transnacional, pois esta é muitas vezes secundarizada face às identidades nacionais. Voltar-se-á a este assunto mais adiante. 
Assim sendo, para se perceber de forma mais completa o complexo institucional de vários níveis (local, nacional, transnacional) e constelações de atores que gravitam em torno dos CEEs, estes deverão ser conceptualizados como complexos e compostos, com vários níveis e dimensões, e como organizações não-lucrativas transfronteiriças que trabalham e que se centram sobretudo em organizações lucrativas (Hertwig, Pries e Rampeltshammer, 2009: 27). Caracterizar os CEEs como organizações complexas significa que será inadequado defini-los apenas como organizações de interesses ${ }^{32}$. Além disso, os CEEs devem ser analisados como organizações compostas por vários níveis e dimensões, em resultado da sua estrutura, dinâmicas internas ou campos de poder e de interesses, observáveis desde o nível local (da fábrica), passando pelo nível nacional empresarial e sindical, até ao nível europeu.

Na verdade, a Diretiva dos CEEs não só mobilizou a representação dos trabalhadores nos locais de trabalho e as administrações, como favoreceu a europeização sindical (Platzer, 2009: 53). Por um lado, os CEEs foram o primeiro projeto genuinamente europeu capaz de potenciar o prestígio das Federações Sindicais Europeias (FSEs) e expandir o seu papel de intermediárias e/ou atores principais na iniciação ou condução dos processos de negociação dos CEEs. Por outro lado, a introdução em larga escala de CEEs instigada pela Diretiva também forçou os sindicatos nacionais a "tornarem-se eles próprios mais europeus" mobilizando ou recentrando recursos internos, tendo um maior cuidado na coordenação de atividades transfronteiriças e intensificando a interação com as respetivas FSEs.

32 Em termos gerais, poder-se-á diferenciar organizações lucrativas e não lucrativas, assim como organizações governamentais e não-governamentais. Os CEEs são organizações "não-lucrativas" e não governamentais. Neste sentido, o seu carácter é bastante simples. Mas considerando a sua natureza como constelações coletivas ou corporativas de atores, então são bastante complexas. As organizações podem ser entendidas como atores coletivos se os seus membros partilham pelo menos alguns interesses mais ou menos homogéneos e se a organização depende fortemente dos recursos dos seus membros (tais como sindicatos ou partidos políticos). Se as organizações (tais como empresas ou universidades) se apoiam numa maior autonomia dos seus membros e se estes têm interesses altamente diferenciados ou mesmo opostos, então são vistas como atores corporativos. Os CEEs balançam entre estes dois tipos ideais de atores coletivos e corporativos. Deverão ser vistos como organizações complexas compostas por grupos diferentes de atores (Hertwig, Pries e Rampeltshammer, 2009: 27-28). 
No entanto, a apropriação que os sindicatos fizeram do tema dos CEEs não foi de todo homogénea e as diferenças entre países e setores são muito vincadas. Enquanto que alguns sindicatos nacionais, por exemplo dos países nórdicos, estão de acordo em conferir aos CEEs funções essencialmente de informação e consulta, na linha daquilo que é a sua tradição nacional, outros concordam com a ideia de que os CEEs devem ter funções de negociação e apoiam de forma ativa esta ideia. Por exemplo, na Alemanha, o IG-Mettal, depois de uma reserva inicial sobre a “opção negocial” dos CEEs, lançou em 2002 uma proposta na Federação Europeia dos Metalúrgicos para uma ligação sistemática entre os recursos dos CEEs e a abordagem da coordenação transnacional já em vigor ao nível da negociação coletiva. O objetivo desta estratégia seria entrar em negociações e tentar concluir acordos setoriais europeus sobre assuntos como a formação nos locais de trabalho (Platzer, 2009: 54).

Mas voltando ainda à Diretiva, ela própria suscita um olhar para os CEEs segundo uma dupla visão (top-down e bottom-up) que cruza diferentes níveis de análise. Como salienta Costa (2008b: 56-57), enquanto produto direto de uma lei comunitária destinada a instituir mecanismos de informação e consulta dos trabalhadores nas empresas ou grupos de empresas de dimensão comunitária, os CEEs são, nesse sentido, herdeiros de uma regulação de cima para baixo (Miller, 1999: 346) que visa criar um sistema transnacional de informação capaz de ser ajustado à estrutura transnacional das empresas ou grupos de empresas de dimensão comunitária. Segundo Boaventura de Sousa Santos (1995: 263; 1997: 16; 2001: 71), estaríamos, assim, diante de um localismo globalizado, observável no modo como uma multinacional está em condições de alargar as suas atividades para além de um registo meramente local ou nacional. Por outro lado, porém, esteve também subjacente à constituição dos CEEs a criação de condições de luta a partir de baixo, o que nos reconduz a um cosmopolitismo - termo utilizado para descrever práticas e discursos de resistência (Santos, 1995: 264; 1997: 17; 2001: 73-74) - ou a uma globalização ancorada (Burawoy, 2000). Na verdade, é possível (pelo menos teoricamente) criar condições para uma organização laboral transnacional assente numa articulação de lutas resultante da partilha de problemas 
comuns aos trabalhadores de uma mesma empresa, ainda que de diferentes nacionalidades, superando-se, assim, barreiras linguísticas e culturais (Hoffmann, 2002: 139).

Segundo Richard Hyman, no longo prazo, a conquista de uma solidariedade genuína resultaria de uma articulação entre uma liderança estratégica e um ativismo democrático. Em seu entender, o desafio dual resultante dos CEEs (que considera ser a experiência onde a legislação social europeia até hoje mais avançou) passa por combinar processos de orientação estratégica com mobilização de base, desenvolvendo tanto "estruturas centralizadas como mecanismos para uma vigorosa participação de base" (Hyman, 2001: 175). Ou, como sustenta Jane Wills (2001: 189), de par com redes horizontais entre trabalhadores europeus, os CEEs potenciam também a criação de redes verticais entre a "base" e o "topo", isto é, entre trabalhadores e administradores das empresas. Ou ainda, como perspetiva Platzer (2009: 54), equacionando uma "europeização horizontal" e uma "europeização vertical". Os resultados que se conseguiram até agora alcançar com os CEEs conduziram a um modelo específico de "europeização horizontal”. Ao nível europeu, o processo politicamente estruturado "de cima” e apoiado por uma grelha estatutária, exigiu e facilitou - via negociações - um processo de europeização "de baixo" (from below). Uma vez que as negociações e o estabelecimento dos CEEs seguem um processo similar e comparável em todos os países europeus, e uma vez que estes processos estão interligados entre fronteiras nacionais, esta parte do processo de desenvolvimento poderá ser descrito como "europeização horizontal". Depois da criação de um CEE as interações horizontais transfronteiriças ajudam a construir uma parte integral de toda a estrutura de comunicações dos CEEs e desempenham um importante papel na forma e no perfil do CEE enquanto atores. Estas interações horizontais - que são baseadas em interesses que podem variar entre cooperação, competição e conflito - são decisivas para a organização de um fluxo estável de comunicação entre as diferentes fábricas e localizações.

Para além desta "europeização horizontal”, Platzer (2009: 55) fala em "europeização vertical". Esta noção parece ser a adequada para se 
perceber o carácter distintivo de um grande número de CEEs enquanto atores transnacionais. Isto é, ela tem lugar quando é possível estabelecer um nível de comunicação e cooperação transnacional capaz de resolver problemas "para além do Estado-nação".

\subsection{Modus operandi dos CEEs: "vida interna", casos específicos e fatores estruturais}

A análise do tipo de acordo é importante enquanto fator de determinação dos campos de atividade e dos meios de ação dos CEEs e tem sido uma das vertentes exploradas em diversos estudos (Hertwig, Pries e Rampeltshammer, 2009: 18). No entanto, a par dessa avaliação do tipo de acordo, um outro ponto de análise centra-se nas funções e modos de funcionamento dos CEE. Neste modus operandi dos CEEs são identificáveis 3 aspetos. Por um lado, a "vida interna" dos CEEs. Trata-se de analisar as práticas internas dos CEEs, ou seja, os modos de funcionamento internos, os fluxos de comunicação e interação entre os diferentes membros do CEE e a existência (ou não) de coesão interna dentro deste órgão de representação (Miller, 1999; Wills, 2000; Cristina, 2009) ou de uma identidade dos CEEs (Whittall, Knuden e Huijgen, 2007).

Um outro aspeto decorrente da atuação dos CEEs prende-se com o reforço da ideia do "estudo de caso" de CEEs específicos ou que atuaram em condições particulares (por exemplo, o encerramento de fábricas) ou setores de atividade específicos. A indústria automóvel europeia tem sido palco de muitos desses estudos (Hertwig, Pries e Rampeltshammer, 2009: 20-21). As principais marcas de produção automóvel foram pioneiras na criação dos primeiros CEEs. Em 1996 todos os grandes construtores automóveis tinham criado órgãos de informação e consulta. Em 1990, a Volkswagen (VW) constituiu o primeiro CEE de uma empresa do setor automóvel. Apesar de se ter constatado uma influência das organizações nacionais (germânicas) de representação de interesses no CEE da VW, os resultados foram positivos, ou seja, a influência do CEE nos processos de tomada de decisão da empresa foi um facto. Além disso, a criação do 
CEE na VW potenciou a criação de um conselho de empresa mundial e, desta forma, esteve na origem de uma "estrutura global multi-facetada".

Um terceiro aspeto que pode elencar-se como evidenciando a operacionalização dos CEEs prende-se com fatores de ordem estrutural. Muitos dos estudos realizados sobre CEE concordam na importância dos fatores estruturais, em especial, a estrutura dos sistemas nacionais de relações laborais, o setor de atividade, a empresa e as atitudes da administração em relação ao CEE. Por exemplo, os estudos de Marginson (1992; 2004) reafirmam que uma abordagem unidimensional para explicar a existência e os modos de funcionamento dos CEEs é demasiado simplista. É a inter-relação do conjunto de características estruturais da empresa que influenciam a decisão dessa empresa colocar em andamento um CEE. Entre estas características estruturais Marginson aponta a propriedade da empresa, a existência de uma estrutura administrativa europeia da empresa e a existência de uma estrutura de produção integrada. Seguindo esta linha de investigação, Marginson et al. (2004) estudaram o impacto dos CEE nos processos de tomada de decisão de oito empresas com sede no Reino Unido e Estados Unidos. Os resultados indicam que a variação na extensão da influência dos CEEs nos processos de tomada de decisão das administrações pode ser explicado por seis variáveis: três estruturais (alinhamento empresarial, estrutura administrativa e plataforma de relações laborais) e três fatores agency-related (política da administração em relação ao CEE, as organizações ligadas aos trabalhadores e a interação no CEE). Nos casos em que o CEE teve influência nas decisões tomadas pelas administrações, Marginson et al. agruparam os assuntos em causa em duas temáticas: primeira, decisões que implicavam reestruturações transfronteiriças com reflexos ao nível da segurança do emprego; segunda, decisões transnacionais que mexiam com direitos e/ou condições de trabalho. Nestes assuntos, o CEE conseguiu ter algum tipo de influência sobre as decisões tomadas pela administração.

Em muitos dos estudos realizados com o propósito de perceber os mecanismos de funcionamento dos CEEs sobressaem algumas conclusões convergentes. Alguns fatores podem ser considerados. Um deles prende-se com o designado efeito sede da empresa (beadquarters'bomeland effect) 
ou "fator casa" (Costa e Araújo, 2009: 131-132; Weiler, 2004). Existe uma clara influência do regime político nacional e em particular do regime de relações laborais do país europeu de onde a empresa é originária. A estrutura interna do CEE, as relações administração-trabalhadores, o papel dos sindicatos, a ideia vigente sobre o funcionamento e sobre o trabalho desenvolvido pelo CEE são aspetos influenciados pelo regime de relações laborais específico do país sede da empresa (Lecher et al. 1999). Um segundo fator influente na estrutura e dinâmicas do CEE é o setor de atividade da empresa. Dependendo de ser uma empresa da indústria automóvel, da energia, do setor químico ou do setor dos serviços, as estruturas e dinâmicas de trabalho do CEE podem diferir (Hertwig, Pries e Rampeltshammer, 2009: 25). Um terceiro fator identificado como tendo influência ao nível da configuração do CEE é a altura em que foi assinado o acordo entre a administração e os trabalbadores. Segundo a Diretiva de 1994 , os procedimentos e regras para a criação de um CEE diferem significativamente antes e depois de 1996 (artigo 13. e artigo 6. ${ }^{\circ}$ da Diretiva 94/45/CE). Sendo assim, a análise do conteúdo do acordo de criação do CEE revela diferenças significativas atendendo ao facto de se ter aplicado o regime do art. $6 .^{\circ}$ ou o do art. $13 .^{\circ}$. O que significa, pois, que os CEEs hoje em vigor são também o produto do momento que presidiu à sua fundação e à situação contextual, societal e legal, prevalecente nessa altura, bem como de decisões estratégicas e situações críticas do passado e de acontecimentos importantes e/ou personalidades marcantes.

\subsection{Os CEEs numa perspetiva organizacional (não lucrativa)}

Os CEEs têm vindo a ser predominantemente analisados como um tipo especial de conselho de empresa ou como um órgão de mediação de interesses entre o capital e o trabalho. Devido à sua configuração multidimensional, Hertwig, Pries e Rampeltshammer consideram que esta perspetiva de análise deve estender-se. Um primeiro ponto de partida é a distinção entre uma perspetiva negocial intra-organizacional e inter- 
-organizacional. Geralmente o tópico da estrutura interna dos CEEs é tratado mais no sentido das condições e mecanismos de cooperação do que no sentido da negociação interna de interesses entre as diferentes fábricas e os delegados nacionais que compõem o CEE. O CEE deverá ser visto não só como uma unidade negocial inter-organizacional, que negoceia com a administração europeia da empresa, mas como a mais importante plataforma para a negociação intra-organizacional entre os diferentes grupos de interesses representados neste órgão (Hertwig, Pries e Rampeltshammer, 2009: 29). Estas dinâmicas e dialécticas entre negociação intra e inter-organizacional são ainda mais importantes nos CEEs devido ao facto de os CEEs serem estruturas duráveis compostas por atores e grupos provenientes de um conjunto amplo de países onde vigoram contextos culturais e institucionais muito diferentes e interesses locais também muito distintos. Em geral, as administrações locais das fábricas e a força de trabalho local partilham os mesmos interesses, ou seja, o interesse básico de manter a produção e o emprego, respetivamente. Para além do mais, os representantes dos trabalhadores nos CEEs não são eleitos por todos os trabalhadores e empregados europeus, mas designados segundo os mecanismos de eleição vigentes em cada país. Este facto faz toda a diferença na comparação dos processos negociais intra-organizacionais, seja nos conselhos de empresa locais ou mesmo nos sindicatos nacionais. Assim, qualquer negociação intra-organizacional entre a administração e os trabalhadores ao nível europeu depende do resultado da mediação e da homogeneização intra-organizacional.

Um segundo elemento que resulta da análise organizacional refere-se ao carácter dos CEEs enquanto organizações não-lucrativas que têm por base leis europeias e nacionais e que atuam em organizações lucrativas ativas na Europa baseadas exclusivamente em leis nacionais respeitantes às suas partes constituintes. Este facto confere aos CEEs um carácter único. Para aqueles autores, para se perceber a lógica dos CEEs é preciso compreender a lógica das empresas internacionais enquanto organizações lucrativas transfronteiriças, assim como ter em atenção os apontamentos teóricos que provêm da análise das organizações internacionais 
não-lucrativas e não-governamentais. ${ }^{33}$ Assim sendo, os CEEs podem ser vistos como genuínas organizações internacionais não-lucrativas que se tornam ativas e efetivas no quadro das organizações lucrativas internacionais. Enquanto que os conselhos de empresa (locais e nacionais) são geralmente vistos como sub-unidades ou partes de uma organização empresarial sujeita a uma lei nacional unitária e enquadramento institucional, a classificação dos CEEs é mais complexa. Os CEEs resultaram de leis europeias que são transpostas para os respetivos edifícios legais de cada país. As diferentes unidades nacionais das empresas enquanto organizações empresariais permanecem - em contraste com a societas europeae - sujeitas exclusivamente à respetiva lei nacional e setting institucional. Em termos formais/legais, os CEEs são, assim, organizações europeias no sentido em que os seus membros partilham um conjunto de regras, uma estrutura predeterminada e o propósito de representação de trabalhadores e de diálogo com a upper-most management ao nível empresarial europeu.

Nestes termos, pensar os CEEs enquanto organizações não-lucrativas europeias a funcionar dentro de organizações de base nacional lucrativas ativas na Europa parece ser cientificamente relevante, uma vez que permite que sejam estudados não só na perspetiva capital-trabalho, ou seja, na relação empregador-trabalhador, mas na perspetiva mais ampla do seu significado no que respeita ao processo de integração europeia. Se, afinal, os CEE não são multinacionais, se são conglomerados mais ou menos insignificantes de nacionalidades, orientados para a satisfação de interesses particulares-localizados ou que, seguindo uma relação centro-periferia, representam o domínio do forte (global) ou fraco (focal) e a imposição dos interesses da sede da empresa, então fará sentido a ideia de que os CEE "não são nem europeus nem conselhos de empresa" (Streeck, 1997). Mas se, pelo contrário, a coordenação e os mecanismos

33 Estas contribuições teóricas remontam à década de sessenta e seguintes, centrando-se nos estudos de Perlmutter, Porter, Bartlett e Ghoshal que desenvolveram uma tipologia baseada em vários tipos-ideais de empresas internacionais que, com algumas alterações, pode ser usada como grelha de análise para os CEEs (Hertwig, Pries e Rampeltshammer, 2009: 30-32). 
de regulação de interesses e talvez até uma "identidade nacional" dos CEEs ao nível europeu se conseguirem provar, sem que haja qualquer ambiguidade em termos do centro de recursos, poder, conhecimento e cultura, então estaremos na presença de uma constelação europeia transnacional.

\subsection{Em busca de uma identidade laboral transnacional}

A construção de uma identidade laboral transnacional através dos CEEs é, com efeito, uma referência incontornável e uma meta a alcançar por parte das organizações representativas de trabalhadores. Como é sabido, não se trata de uma questão exclusiva dos CEEs mas que é extensível às várias formas organizativas do mundo do trabalho que pretendem construir uma organização mais coesa no plano transnacional, com destaque para os sindicatos. Não tem sido fácil, porém, edificar essa identidade laboral transnacional devido a um conjunto interligado de fatores: uma forte presença de mecanismos de regulação laboral nacional (regimes jurídicos, salários e condições de trabalho) dificulta uma desnacionalização dos sistemas de relações laborais; um notório défice de teorização sobre o "sindicalismo global"; uma força de trabalho mundial com baixas ligações (em torno dos 15\%) a uma economia política global; uma escassez de recursos financeiros (mais notória em contexto de crise) para potenciar deslocações para um espaço físico comum de protesto (não obstante os voos low-cost poderem funcionar como atenuante ou a Internet poder abrir caminho, em especial para os defensores do e-sindicalismo, a uma $\mathrm{V}$ Internacional Operária!); uma incorporação de lógicas de competição e conflitualidade nos discursos e práticas sindicais transnacionais (é bom não esquecer, por exemplo, que a solidariedade laboral pode ser minada por situações em que a luta por melhores condições salariais num determinado país pode significar a degradação da relação salarial ou mesmo o aumento do desemprego noutro país); os atropelos patronais aos direitos laborais nas empresas multinacionais; a fraqueza dos canais de representação dos interesses 
laborais no plano transnacional (onde a OIT aparece isolada face à presença de instituições como o FMI, a OMC, o Banco Mundial, a OCDE, o G8...; etc. (Costa, 2008b: 39-42; 2010: 24).

Por outro lado, como foi sugerido na subsecção anterior, há múltiplas escalas ou níveis de análise envolvidos nos CEEs, ainda que, estando a Diretiva concentrada em informação e consulta sobre "questões transnacionais" suscetíveis de afetar os interesses dos trabalhadores, possa legitimamente fazer sentido tentar ver de que modo uma identidade laboral se projeta ao nível transnacional. Mas não é uma tarefa fácil, tanto mais que os representantes em CEEs tendem a privilegiar o nível nacional e só depois o europeu. Com efeito, a perceção de interesses conflituais e a ausência de um entendimento comum dos problemas são obstáculos à cooperação transnacional no contexto dos CEEs e, nesse sentido, a identidade coletiva enquanto agregadora de interesses é reduzida (Pulignano, 2007: 76). Ao estudarem uma empresa anglo-holandesa do setor metalúrgico (a Corus), Timing e Veersma (2007) alertam para as consequências práticas do paroquialismo, protecionismo e para a ausência de um mesmo espaço cultural que permite retirar duas ilações de fundo. Por um lado, as construções de identidade de base nacional nos CEEs servem para reforçar as barreiras que geralmente dividem os representantes dos trabalhadores. O que têm em comum (que é o facto de serem todos trabalhadores) é marginalizado face ao que os separa, que é simultaneamente o facto de serem trabalhadores britânicos ou holandeses. Na base das suas identidades de base nacional, argumentou-se que a interação no seio do CEE era encenada e pouco verdadeira. Por outro lado, como consequência das convenções morais qualitativamente diferentes associadas às relações laborais nacionais e práticas empresariais diferentes verificou-se que a dissonância cognitiva que resulta da amálgama de culturas inibe a capacidade de comunicação entre os trabalhadores, a predisposição para cooperarem e a confiança uns nos outros com base num abrangente "mundo em comum" (Timing e Veersma, 2007: 52).

Numa linha de pensamento próxima desta, Bicknell (2007) reporta-se aos efeitos adversos da identidade nacional na promoção do desenvolvimento de CEEs. Tendo por referência a "identidade alemã" nos CEEs, 
a autora ilustra bem uma correlação suscitada pelos CEEs: quanto maior a variedade de nacionalidades e a mistura de culturas nos CEEs, maior dificuldade terão os representantes em trabalhar juntos. Os representantes dos CEEs que ou falam a mesma língua ou partilham uma segunda língua comum com alguma fluência têm, em geral, menos problemas do que quando a comunicação tem de passar por um intérprete. Com efeito, como demonstraram Costa e Araújo (2009: 112) tendo por referência os representantes portugueses em CEEs, em especial para os países do Sul da Europa a língua poderá, pois, constituir-se como fator de marginalização (Miller et al., 2000: 314; Stirling e Fitzgerald, 2001; Stirling e Tully, 2004; Tully, 2004).

Mas a capacidade de comunicação não se prende só com a troca de informação. Ela está também associada a questões de poder e de controlo. A capacidade para falar a "língua da empresa" pode determinar qual o representante do CEE que tem maior probabilidade de ser influente. $\mathrm{Na}$ pesquisa conduzida por Bicknell (2007) todos os porta-vozes não alemães nas empresas alemãs eram de países linguística e culturalmente próximos da Alemanha (Áustria, Holanda, Dinamarca). No entanto, o fator cultural mais problemático apontado nas entrevistas e nos questionários foi a enorme variação de sistemas de relações laborais vigentes na Europa. A perceção que os representantes nos CEEs têm desses sistemas é muitas vezes incompleta ou inexistente levando a problemas de entendimento tão graves como os que são devidos ao facto de não falarem a mesma língua. É muito difícil a um representante conseguir perceber até que ponto a "cultura nacional" influencia a sua forma de pensar, as suas decisões e ações. Estas diferenças tornam-se mais evidentes num contexto internacional. Quando as culturas colidem, como acontece previsivelmente num grupo internacional, o resultado pode ser uma retirada para posições de “zonas seguras" nacionais, ou um ataque ofensivo que pode levar ao confronto, ou ainda uma troca de opiniões de forma a chegar-se a um certo nível de entendimento e de cooperação. Para alcançarem um resultado positivo, os atores envolvidos deverão ser capazes de diferenciar quais os problemas que são o resultado de efeitos culturais nacionais, e quais os que são devidos à diferença de opiniões (Bicknell, 2007: 125). 
Não obstante os representantes de trabalhadores em CEEs terem dificuldade em sair do seu ambiente nacional e o alcance da identidade coletiva enquanto agregação de interesses ser reduzido (Puligmano, 2007: 76), Herman Kotthoff (2007) identifica três níveis de perceção da identidade europeia nos CEEs: a) o nível da ação, das políticas e da efetividade dos CEEs; b) o nível da perceção que os membros dos CEEs têm sobre uma pretensa existência de uma solidariedade europeia dentro do CEE; c) o nível das repercussões do CEE na consciência dos membros de conselhos de empresa nacionais que não são delegados do CEE. Os resultados a que chegou confirmaram a não existência de uma identidade europeia muito desenvolvida nos CEEs. O autor sublinha, aliás, 5 tipos de indentidades nos CEEs (Kotthoff, 2007: 178-179):

i) Um CEE de identificação europeia, de relação afetiva, sentimento de pertença, interdependência e solidariedade;

ii) Um CEE de "pensamento europeu”. Pressupõe, desde logo, uma relação funcional e racional e já não tanto afetiva, tanto mais que se olha para os CEEs como dispondo de uma estratégia com enquadramento europeu e de uma agenda transnacional. Trata-se, pois, de valorizar a cooperação internacional institucionalizada;

iii) Um CEE onde o papel dos delegados é rotineiro, habitual e profissional. Isto pressupõe uma organização interna efetiva, contactos de trabalho naturais entre membros que ocupam um papel dentro do CEE;

iv) Um CEE que intensifica e institucionaliza o acesso à administração ao nível do grupo: discussões privadas entre o presidente do CEE e o chief executive officer; um programa efetivo e significativo no segundo dia de reunião do CEE ("informação disponibilizada pela administração"); acesso facilitado aos setores de topo e à divisão de gestão;

v) Um CEE de trabalho em rede: contacto regular e informal entre membros que não estão envolvidos na organização e trabalho do CEE; oportunidade de conhecimento e aproximação mútuos; troca de informações sobre aspetos da vida quotidiana; oportunidade de conhecer os padrões de representação laboral praticados noutros países (diversidade cultural). 
A análise de Kotthoff pode ser complementada com a de Telljohann (2007: 164-165). Para este autor, colocam-se dois desafios à identidade coletiva europeia por meio dos CEEs. O primeiro envolve a transformação dos CEEs em verdadeiros atores da representação de interesses. $\mathrm{Na}$ verdade, o que se tem constatado é que os direitos dos CEEs estão limitados à informação e consulta e como tal não possuem direitos em matéria de negociação e de co-gestão, o que lhes permitiria influenciar as decisões das administrações. Isto significa que os CEEs não podem ser considerados órgãos efetivos de representação de interesses. Esta lacuna ao nível dos direitos leva a que na maioria dos casos as práticas sejam "simbólicas" ou "CEE de serviços" (nos termos propostos por uma das tipologias abaixo analisadas), o que em muitos casos tem um impacto negativo na motivação dos delegados. Se é certo que a identidade coletiva pode ser desenvolvida na base de uma atividade comum direccionada para a obtenção de objetivos comuns, torna-se difícil aos CEEs desenvolverem essa atividade coletiva enquanto permanecerem entidades mais ou menos passivas e subordinadas aos ditames das administrações.

Um segundo desafio passa pelo desenvolvimento de uma identidade europeia específica que compreende fatores como a aprendizagem intercultural, a confiança recíproca e a coesão interna. Isto significa que o processo de desenvolvimento de uma identidade europeia é o resultado de um processo de aprendizagem e de experiências: dependem ambos muito do fator tempo, da disponibilidade de recursos e da qualidade do apoio externo. Para Telljohann o desenvolvimento de uma identidade coletiva europeia dos CEEs depende da capacidade de os seus membros autonomamente identificarem interesses e valores comuns, concordarem em prosseguir objetivos comuns e, finalmente, definirem e colocarem em prática uma estratégia comum. Para que os CEEs possam desenvolver um papel ativo terá de haver entre os seus membros a convicção de que o nível de ação europeu é, de facto, o mais apropriado.

Por fim, para além das análises de Kotthoff e de Telljohann, a proposta de Whittall, Knuden e Huijgen (2009: 168) apoia-se no uso de novas formas de tecnologias de informação e comunicação (TIC) como estratégia para desafiar os instintos paroquiais dos CEEs e potenciar 
uma identidade coletiva. As TIC - por meio de uma "proximidade virtual" - conferem aos delegados dos CEEs a oportunidade de atribuírem outro rumo à natureza abstrata e muitas vezes impessoal das relações transfronteiriças historicamente características do internacionalismo operário. A ideia é, pois, a de verificar se as TIC poderão ou não ajudar a solidificar as relações entre trabalhadores separados geograficamente e a organizar ações transnacionais, levando à emergência de uma identidade transfronteiriça.

Whittall, Knuden e Huijgen (2009: 172-174) argumentam que as identidades coletivas apenas evoluirão nos CEEs em que a comunicação entre os representantes seja suficientemente intensa e frequente. Claro que a comunicação deverá lidar com problemas reais e relevantes e deverá atender às pressões e riscos externos e, em geral, comporta relações com atores externos ao CEE. A sua relevância pressupõe que tenham sido desenvolvidos métodos para ultrapassar as barreiras colocadas pela língua e pelas diferenças culturais e experimentado um esforço comum por parte do CEE para que a diferença seja positiva. Considera-se, assim, que as TIC são uma plataforma que pode ser usada para ir além da natureza paroquial do trabalho, expandindo as experiências dos delegados dos CEEs e facilitando os contactos entre $\mathrm{si}^{34}$. Em resumo, o acesso às TIC confere aos delegados dos CEEs uma fonte de poder para além do local de trabalho e ajuda as organizações a adaptarem-se a um novo ambiente global.

Como se depreende destas várias incursões em busca de uma identidade transnacional nos CEEs, são distintas as formas de atuar dos CEEs, o que significa que a sua prática nos confronta com diferentes modelos de funcionamento que ora se aproximam, ora se distanciam da referida identidade transnacional. Nesse sentido, vale agora a pena olhar para algumas tipologias (modelos) sobre os CEEs.

${ }^{34}$ Para uma análise das potencialidades da Internet no contexto de um capitalismo globalizado/conectado em rede/informatizado, cf. Lee (2000; 2004; 2006), Waterman (2004), Webster e Lambert (2004), ou Freeman (2005). Para uma síntese dos prós e contras do e-sindicalismo, cf. Costa (2008a). 


\section{Tipologias de CEEs}

Uma pioneira proposta de tipologias sobre os CEEs foi desenvolvida por Lecher et al. (1999; 2001; 2002). Nos termos desta tipologia, privilegia-se uma abordagem centrada no ator, mas que, em simultâneo, valoriza a relação de interdependência entre a estrutura e a ação que molda a constituição dos CEEs. Consequentemente, a constituição dos CEEs é analisada tanto em termos da sua "vida interna" como das suas relações externas relevantes de acordo com quatro "campos de interação": 1) interação entre o CEE (representantes dos trabalhadores) e a administração; 2) interação entre membros do CEE; 3) interação entre o CEE e as instituições nacionais de representação de interesses dos trabalhadores e da força de trabalho; 4) interação entre o CEE e os sindicatos. Centrando-nos na "capacidade de ação" do CEE como resultado das trocas dinâmicas dos quatro campos de interação ${ }^{35}$, chega-se a quatro tipos de CEEs: simbólicos, orientados para serviços, orientados para projetos e participativos (Lecher et al., 1999; 2001: 52-58; 2002: 179-181).

O CEE simbólico é um órgão que, apesar de constituído, na verdade não funciona. As suas atividades cingem-se às reuniões anuais acordadas com a administração central. Os representantes dos trabalhadores no CEE comportam-se de forma passiva, deixando à administração a condução das reuniões e os assuntos tratados. Não se fazem valer do direito de ter reuniões preparatórias ou de formar grupos de discussão por forma a cimentar a confiança e a coesão entre si. Por razões estruturais, organizacionais ou políticas - variam de caso para caso - o CEE é incapaz ou é

35 Como sublinha Cristina (2009: 38), subjaz uma dupla lógica à tipologia avançada por Lecher e colaboradores: por um lado, os tipos ideais baseiam-se nas modalidades de funcionamento dos CEEs; por outro, traduzem os interesses e o comportamento dos atores envolvidos nos processos de interação dos CEEs. Como os próprios autores admitem, esta dupla lógica suscita dificuldades na atribuição de casos concretos às diferentes categorias, já que os quatro tipos ideais não se excluem mutuamente, o que, de certa forma, questiona a própria noção de tipologia. Ainda assim, a proposta de Lecher et al. foi a primeira a demonstrar que o funcionamento dos CEEs é o produto da interação dinâmica entre os processos internos de interação entre os representantes e as ações de outros atores (administração, estruturas de representação existentes a nível nacional e sindicatos), enquadrada num conjunto específico de condições estruturais que ora limitam ora apoiam o desenvolvimento dos CEEs. 
relutante em obter e processar informação assim como em desenvolver os seus próprios recursos para além daquilo que está estipulado no acordo. Os sindicatos estão apenas formalmente incluídos, se é que estão de todo.

O CEE orientado para serviços é um órgão para ajuda e informação mútuas. Funciona como uma "agência de serviços" para os representantes dos trabalhadores ao nível local nacional ou da empresa, fornecendo informação adicional reunida a nível europeu, através das trocas transfronteiriças e da comunicação horizontal das experiências nacionais. Os membros individuais do CEE, que em geral têm um acesso razoável aos recursos, funcionam como fornecedores de serviços aos outros membros do CEE. O tipo de serviços prestados poderá incluir apoio para a representação de interesses ao nível nacional e local, quer através do comité restrito do CEE ou de membros destacados do próprio CEE. Os CEEs de "serviços" foram constituídos para permitirem o acesso, processar e enviar informação com "valor europeu acrescentado", ou seja, informação que não seria disponibilizada e tornada acessível sem a existência de um órgão de informação e consulta de nível europeu.

O CEE orientado para projetos vai um pouco além do anterior nos seus propósitos. É um órgão que define e executa projetos baseados no desenvolvimento sistemático das suas estruturas internas operacionais e de comunicação. Define as suas próprias tarefas (projetos), as quais, se necessário, tem capacidade para implementar independentemente da administração. Esta abordagem sistémica e estratégica serve para consolidar e construir o CEE, cimentar a confiança mútua e as experiências de cooperação entre os seus membros, assim como criar estruturas sustentáveis para o seu funcionamento. Os projetos - por exemplo, a recolha sistemática e a troca de informação relacionada com as condições (nacionais) de trabalho, padrões sociais, etc. - dão origem a recursos informativos transnacionais que poderão ser usados nas interações com a administração central ou local da empresa, e que demarcam e estruturam novos tópicos para negociação.

O CEE participativo visa expandir o seu leque de atividades para além das atribuições normalmente associadas aos CEEs enquanto órgãos de informação e consulta. Pretende, assim, ser uma estrutura com poderes 
consultivos formalmente regulamentados, com capacidade para negociar e propor iniciativas conjuntas com a administração. A via para se conseguirem acordos e posições conjuntas com a administração assenta, em geral, no campo dos temas que são consensuais para todos os intervenientes, os quais podem dar origem a projetos conjuntos ou acordos firmados. As negociações sobre temas "quentes" (hard issues), tais como horários de trabalho ou proteção no local de trabalho, exigem um conjunto complexo de requisitos relacionados com a constituição interna do CEE, constelações específicas de interesses (por parte do próprio CEE e da administração), e pressões para agir que podem implicar processos de troca. Os CEEs participativos caracterizam-se por intensivas interações internacionais e pelo desenvolvimento de uma teia genuína de relações laborais de nível europeu. As atividades dos CEEs participativos incluem, por exemplo, acordos sobre saúde e segurança, igualdade de oportunidades, informação e direitos sindicais, acordos sobre proteção social dos trabalhadores nos casos de fusões ou reestruturações internacionais das empresas, etc.

Ao ter presente esta tipologia, Platzer (2009) alerta para o facto de os quatro tipos de CEEs identificados não apresentarem uma sequência linear de fases de desenvolvimento. Um CEE pode muito bem, à partida, ir na direção de se tornar um CEE participativo sem ter sido antes um CEE orientado para projetos. O desenvolvimento e performance de um CEE são variáveis. Por um lado, um CEE pertencente a uma dada categoria pode permanecer sempre nessa categoria. Para alguns CEEs, a orientação para serviços ou projetos pode muito bem ser uma estratégia consciente e a mais adequada. Por outro lado, os CEEs não estão imunes à possibilidade de regressão, em particular por causa da grande instabilidade das estruturas empresariais ou em resultado das estratégias dessas mesmas estruturas.

Ao analisar 23 estudos de caso $^{36}$ verifica-se que aproximadamente metade dos CEEs podem ser classificados de "simbólicos" e a outra metade (distribuída de modo repartido) são classificados nas outras três

36 Platzer (2009) analisa 23 estudos de caso em empresas do setor metalúrgico, químico, banca, seguros e setor alimentar em Itália, Reino Unido, Alemanha e França. 
categorias. Ou seja, o peso dos CEEs "simbólicos" é ainda muito significativo. Em muito menor número, os CEEs "participativos" foram encontrados em negociações de temas soft, tais como acordos-quadro sociais, e só em poucos casos estiveram presentes na negociação de temas hard, como o encerramento de fábricas e as reestruturações empresariais. O campo de ação dos CEEs "participativos" - cujos interesses e capacidades vão além da informação e consulta - tem, no entanto, vindo a crescer progressivamente.

Além da tipologia de Lecher et al., uma outra tipologia relevante foi proposta por Helen Bicknell. Ao seguir de perto as formulações teóricas de Marginson $(2000,2004)^{37}$, assim como de Perlmutter (1969) ${ }^{38}$, e tendo por referência o "caso alemão"39, Bicknell (2007: 113) propõe 3 tipos-ideais de CEEs: etnocêntricos, policêntricos e eurocêntricos:

Nos CEEs etnocêntricos os representantes do país de origem da empresa dominam os procedimentos e estão mais próximos da administração. Os representantes dos outros países são marginalizados. O CEE tende a ser visto como desnecessário ou ineficiente pelos representantes que provêm de sistemas inclusivos de representação dos trabalhadores. Os representantes dos outros países podem beneficiar do acesso à informação.

Nos CEEs policêntricos, o CEE é considerado uma plataforma de troca de informação da qual beneficiam todos os representantes. Os represen-

37 Marginson sugere os conceitos de etno-, poli- e euro-centrismo associados aos CEEs, relacionando esta categorização com a tipologia de Lecher et al. (2001) vista anteriormente. Marginson descreve os CEE como "policêntricos" quando os representantes nacionais utilizam os CEE para atingir os seus próprios interesses e neste caso pertenceriam à categoria dos CEE "simbólicos". Os CEE dominados pelos representantes locais da empresa-mãe são descritos como "etnocêntricos" e corresponderiam à categoria dos CEE de "serviços" ou "orientados para projetos". Aqueles que arriscam uma nova identidade "europeia", diferente daquela que domina as estruturas de representação do país de origem, seriam classificados de "eurocêntricos" ou, segundo a tipologia de Lecher et al., de "participativos".

38 Este autor avança os conceitos de etno-, poli-, regio- e geo-centrismo a propósito da análise das estratégias de internacionalização das empresas. Em seu entender, as empresas têm uma "predisposição estratégica" para o desenvolvimento internacional, dependendo da estrutura da empresa, da forma como se desenvolve internacionalmente (crescimento ou aquisição), da gestão e estrutura organizacional.

39 Para Bicknell a influência da identidade alemã nos CEEs é complexa mas de grande importância porque os representantes alemães estão ativamente envolvidos em cerca de três quartos de todos os CEEs existentes, quase sempre como office holders. 
tantes do país de origem da empresa procuram de forma ativa incluir os outros representantes nas reuniões e em posições de responsabilidade. A administração poderá “jogar” os países uns contra os outros, mas este enviesamento deverá ser corrigido através da "confiança”, do "diálogo" e da "formação".

Nos CEEs eurocêntricos, o CEE desenvolve uma identidade europeia clara. Além disso, são elevados os níveis de confiança interna e de comunicação entre os membros, os office-holders e a administração. Por outro lado, é claramente planeada uma agenda europeia comum.

De acordo com Bicknell (e tendo sempre presente a tipologia proposta por Lecher et al.), os CEEs mais etnocêntricos (mais simbólicos na acepção de Lecher et al.) são aqueles em que os representantes dominam os procedimentos e que quase não vêem vantagens nos CEEs. Os CEEs que poderão ser classificados de policêntricos adequam-se à tipologia de CEEs de serviços ou orientados para projectos. Muito poucos poderão ser classificados de eurocêntricos. Os mais eurocêntricos serão os CEEs bem organizados e estruturados, com ligações próximas às organizações sindicais nacionais e internacionais, e que pertencem a empresas com uma orientação internacional muito vincada.

\section{3. "Boas práticas" em CEEs}

O título desta secção poderia ter sido apresentado sob a forma de interrogação. Desde logo, atendendo ao sentimento de ineficácia dos CEEs que vários estudos (baseados na voz dos representantes em CEEs) apontam, bem como ao reportado défice de poder associado aos CEEs, traduzido num desequilíbrio de forças entre trabalhadores e administrações das empresas (Costa e Araújo, 2007b; 2007c; 2009). Aliás, não foi também por acaso que, na parte final do capítulo 1, se analisaram as razões (i.e., as limitações) pelas quais os representantes sindicais sobretudo clamaram por uma revisão da Diretiva. E não foi igualmente por acaso que, ainda neste capítulo (no quadro dos estudos realizados sobre os CEEs), se alertou para as dificuldades em criar uma identidade transnacional por via dos CEEs. 
Mas estamos em crer que será mais importante realçar sobretudo o papel dos CEEs enquanto instituições vocacionadas para a melhoria das formas de participação laboral no quadro, aliás, de uma diversidade de contextos e sistemas de relações laborais. Como refere Beirnaert (2006: 9), a maior parte dos CEEs são influenciados por diversos elementos contextuais: a relação com a administração, o sistema de relações laborais dominante e cultura de um país, a idade do próprio CEE e a sua maturidade, a cultura empresarial que varia em função do tipo de empresa, o setor de atividade, a localização, etc. Como consequência, é impossível definir apenas uma boa prática que seja aplicável a todos os CEEs. $\mathrm{E}$, para além disso, as diferentes experiências poderão revelar-se importantes fontes de aprendizagem entre CEEs.

Esta constatação serve, pois, de pretexto para uma auscultação de boas práticas dos CEEs em distintos domínios, tais como: relação entre os membros dos CEEs; relação com os sindicatos; relação com a administração; processos de formação; formas de comunicação; reestruturação empresarial; questões emergentes (que vão além da informação e consulta), etc. No fundo, ao olharmos para as boas práticas estamos a perspetivar o modo como os CEEs podem ser capazes de superar particularismos nacionais, de se destacar pelo seu carácter pró-ativo, de permitir a expressão de um sentimento de pertença forte por parte dos representantes de trabalhadores que os compõem, etc., etc.

\subsection{Práticas generalizadas dos CEEs}

Começando pelo domínio das prática generalizadas dos CEEs, Beirnaert (2006: 12-18) reporta-se a vários exemplos. O caso do CEE da British Airways é um deles, sendo que nesta multinacional o primeiro acordo assinado data de setembro de 1996. Houve alguma dificuldade para que as partes envolvidas chegassem a um acordo concreto para a criação de um CEE e só depois de muita pressão por parte dos sindicatos é que a administração concordou em formar um CEE que representasse todo o grupo a nível europeu, sem exceção (inicialmente o grupo pretendia 
excluir do CEE os representantes do Reino Unido). Como foi referido no capítulo 1, uma das debilidades da Diretiva 94/45/CE assentava na definição pouco apertada das noções de informação e consulta. A Diretiva deixava os conceitos abertos à interpretação e negociação das partes envolvidas. No acordo inicial da British Airways (BA) estes problemas de alguma indefinição a propósito de informação e consulta subsistiam pelo que, em 2005, foram sujeitos a uma definição mais rigorosa. O novo acordo passou a conter direitos de informação e consulta mais fortes e mais claros, nomeadamente ao estabelecer uma lista mais específica de assuntos objeto de informação e consulta. Para além dos assuntos referidos na Diretiva o acordo inclui as questões da saúde e segurança, igualdade de oportunidades, regulamentação do tempo de trabalho, formação e mudanças nos tempos de voo. Outra nova regra que ficou estipulada no novo acordo refere que sempre que a administração decida contrariamente à opinião expressa pelo CEE, este tem o direito de convocar uma nova reunião com a administração da BA para que se chegue a acordo. Ainda assim, apesar destas vantagens do CEE da BA é sempre necessário manter uma vigilância apertada sobre as boas práticas ${ }^{40}$.

Além da BA outros exemplos podem aqui ser recuperados: o do grupo HSBC (grupo ligado à banca e a serviços financeiros), o grupo Arcelor (produção de aço, presente na Europa e América Latina) e o da VW (setores metalúrgico e de serviços e comércio). O CEE da HSBC foi criado em 1996 e revisto em 2001. O novo acordo aumentou o número de representantes (de 20 para 30 elementos, no máximo) e estipulou que o número de trabalhadores que garante a um país ter um representante no CEE baixasse de 150 para 50, o que fez aumentar significativamente a representatividade do CEE. Têm sido detetadas algumas dificuldades no funcionamento deste CEE, problemas em parte causados pelo facto de os representantes estarem pouco habituados/sensibilizados a olharem para além do seu contexto profissional imediato. Há também alguma rivalidade

40 Com efeito, em aparente contradição com as boas práticas da BA, traduzidas num upgrading do acordo, na mesma BA, numa fase posterior, uma representante dos trabalhadores no CEE da BA não viu os seus direitos reconhecidos, isto, é, não viu a sua atividade enquanto representante reconhecida pela empresa (Hoffman, 2008: 10-11). 
entre sindicatos no interior da HSBC. O acordo assinado em 2001 estipulou a criação de um comité restrito, o que aumentou a possibilidade de os representantes dos trabalhadores poderem mais facilmente influenciar a agenda das reuniões. Outro desenvolvimento positivo registou-se na disposição das pessoas nas reuniões: passou-se de uma mesa com "dois lados" distintos para cinco ou seis mesas diferentes onde há mistura de pessoas de diferentes nacionalidades e condições de representação e onde representantes de trabalhadores e da administração se encontram misturados. A ideia é eliminar a distinção "eles e nós" criando condições de aproximação entre as duas partes.

Quanto ao grupo Arcelor, deve dizer-se que o mesmo resultou da fusão de três empresas em 2001, cada uma delas já possuía um CEE que, entretanto, foi extinto tendo sido renegociado um novo acordo, conduzido por um Grupo Especial de Negociação e um grupo de coordenação da Federação Europeia dos Metalúrgicos (FEM). O novo acordo estabelece a possibilidade de uma segunda reunião anual a pedido da maioria dos delegados do CEE. O comité restrito reúne quatro vezes por ano e cada membro eleito tem a possibilidade de ter um período de formação de 12 dias. É possível a criação de grupos de trabalho sobre assuntos a designar e é também possível convidar peritos para assistirem às reuniões. O CEE tem ao seu dispor um secretário, dois administrativos e uma sala de reuniões permanente. $\mathrm{O}$ acordo contem uma lista detalhada de competências que, em geral, estão reservadas aos órgãos nacionais de informação e consulta como saúde e segurança, aprendizagem ao longo da vida e progressão na carreira. Possui definições claras de informação e consulta. O CEE tem o direito de expressar a sua opinião durante o processo de decisão. O acordo reconhece oficialmente a FEM como membro do CEE.

O caso do CEE da Volkswagen (VW) é sobretudo ilustrativo até onde algumas empresas foram na questão do envolvimento dos trabalhadores nos processos de tomada de decisão através dos CEEs. O CEE da VW é um caso raro por várias razões, incluindo o lugar que ocupa na estrutura de representação de interesses nacional e internacional da multinacional. Trata-se de um CEE que emergiu na consequência de processos de interação entre a administração do Grupo, os comités de empresa (betriebsräte) e 
os representantes dos trabalhadores no conselho de administração num quadro de globalização da empresa.

O Acordo para a constituição do CEE da VW foi concluído em 1992, antes da entrada em vigor da Diretiva dos CEEs e foi reformulado algumas vezes depois disso, em virtude dos vários processos de reestruturação e de aquisições que afetaram o Grupo. Estudos de caso entretanto realizados mostram que tanto a administração geral do Grupo como as administrações das empresas subsidiárias e os representantes dos trabalhadores estão satisfeitos com o CEE e evidenciam os benefícios que daí resultaram para ambas as partes e para a empresa no seu todo ${ }^{41}$. As vantagens mais referidas do CEE da VW têm sido as seguintes (Eurofound, 2008: 6):

- Os representantes da administração da VW consideram o CEE um instrumento útil para envolver os representantes dos trabalhadores nas políticas do Grupo;

- Os representantes da administração das subsidiárias da VW no Reino Unido descrevem o envolvimento com o CEE como uma forma excelente para compreenderem a forma de funcionar do Grupo e a melhor maneira para se perceber aquilo que se passa nos diferentes países onde o Grupo tem operações;

- Do ponto de vista dos representantes dos trabalhadores, o caso da VW mostra que um CEE que consegue criar coesão interna e que se baseia numa visão estratégica pode tornar-se um fator de influência na expansão transnacional do Grupo.

Os procedimentos descritos para o caso da VW diferem bastante da maioria dos outros casos. Os representantes dos trabalhadores são envolvidos nos processos de tomada de decisão numa fase muito embrionária do processo, e estão envolvidos na decisão final em vários comités. Trata-se de um processo permanente de comunicação e de diálogo. Assim, se uma fábrica pretender despedir trabalhadores, o departamento de pessoal é envolvido. O departamento de pessoal informa os diretores de pessoal

41 Este será, com efeito, um dos estudos de caso analisados no capítulo 5. 
das fábricas envolvidas que, por seu lado, discutem o assunto com os representantes dos trabalhadores. Outros membros da administração, tais como o diretor financeiro e o diretor de produção, também são envolvidos. Nas reuniões do CEE os resultados obtidos através do envolvimento dos representantes dos trabalhadores são apresentados e, finalmente, adotados. A abordagem seguida pela administração do Grupo, ao envolver os representantes dos trabalhadores no processo de consulta numa fase ainda muito embrionária, colhe o apoio generalizado dos representantes dos trabalhadores.

Vejamos agora alguns domínios mais específicos onde é possível constatar a existência de boas práticas nos CEEs.

\subsection{Formas de relacionamento entre atores}

O domínio do relacionamento entre os representantes de trabalhadores em CEEs é condicionado por um amplo conjunto de fatores (potencialmente desestabilizadores), alguns deles já mencionados anteriormente: aspetos linguísticos, cultura, diferentes leis laborais e estruturas sindicais, estruturas e estratégias patronais, recursos ao dispor dos CEEs, falta de continuidade dos representantes nos CEEs, escassez de contactos entre representantes, etc. (Eurofound, 2008: 5). No seu conjunto, tais fatores podem suscitar desentendimentos e falta de cooperação. Algumas soluções têm sido encontradas para melhorar estas dificuldades: na Unilever (indústria alimentar) foi desenvolvida uma folha informativa padrão distribuída pelas diferentes fábricas do grupo. Ela contém um mínimo de informação traduzida nas diferentes línguas dos representantes (Clarck e Bamford, 2002: 28).

O relacionamento com a administração é crucial para o bom funcionamento dos CEEs, sendo indispensável, para o efeito, assegurar que a administração aceita que os representantes do CEE devem ser eleitos de acordo com as leis do país que está representado (Clarck e Bamford, 2002: 29). Na Tyco (eletrónica/setor químico e metalúrgico) quando o acordo para a criação do CEE estava a ser negociado os sindicalistas 
presentes no Grupo Especial de Negociação fizeram pressão para que fosse incluída uma cláusula que exigia que os membros do CEE fossem eleitos por órgão representativos (works councils/comissões de trabalhadores ou sindicatos) ou, quando estes não existissem, de acordo com a lei em vigor no país em questão. Esta cláusula impediria, de certa forma, a interferência da administração no processo.

Quanto à esfera do relacionamento com os sindicatos, Clarck e Bamford (2002: 32) referem-se à importância de assegurar uma forte presença sindical nos CEEs como forma de reforçar a cooperação CEEs/sindicatos. Mas para o efeito é também importante que os sindicatos assumam uma atitude positiva em relação aos CEEs e estejam dispostos a canalizar recursos para garantir que eles funcionem. Há exemplos desse investimento e empenho: em Espanha, as CCOO e a UGT acordaram entre si um sistema para a nomeação dos representantes nos CEEs. Naquele país, a Bayer criou o Fórum Espanhol da Bayer (indústria química), que é a transposição do Fórum Europeu para o nível nacional. É um órgão de informação e consulta que atua entre os sindicatos e a Bayer Espanha. Esta organização permite a coordenação sindical entre todos os locais de trabalho da Bayer em Espanha.

\subsection{A questão da comunicação e o papel das novas TIC}

A projeção e divulgação da atividade de um CEE é também um caminho decisivo para a promoção de boas práticas, em especial quando o CEE é desconhecido não só do público em geral como dos coletivos de trabalhadores. Dir-se-á que, neste caso, o papel de "vender a imagem" do CEE por parte do representante é elementar. Mas outro passo importante passa por alternar os locais de realização de reuniões. Na empresa Valeo (componentes de automóveis/setor metalúrgico), como forma de gerar uma maior consciência do trabalho do CEE, cada uma das reuniões do Comité Restrito é realizada num local diferente, e não sempre na sede da empresa. No fundo estamos perante o reconhecimento, por um lado, de comunicar para fora e de promover formas de comunicação descentra- 
lizadas, maximizando e valorizando o papel das diferentes filiais de uma empresa. Mas a questão da comunicação desenvolve interfaces com as questões do relacionamento entre atores (mencionada acima), ou melhor, poder-se-á dizer certamente que quanto melhor for a comunicação entre atores (da parte patronal e sindical) envolvidos nos CEEs melhor será o relacionamento entre eles.

$\mathrm{Na}$ verdade, um dos conhecidos problemas associados ao funcionamento dos CEEs prende-se com a deficiente comunicação (por vezes mesmo indiferença) dos membros dos CEEs e/ou trabalhadores face ao trabalho do CEE. Esta indiferença só poderá ser ultrapassada se os trabalhadores e/ou membros forem devidamente informados do trabalho do CEE e estiverem ativamente envolvidos nesse trabalho através de formas de comunicação adequadas. Um exemplo positivo em relação à comunicação reportado por Beinaert (2006: 10-11) sucedeu na empresa belga ligada à banca e aos seguros, KBC, cujo CEE criou um sítio na Internet aberto a todos os interessados, ou o grupo Hilton (hotéis), cujo sítio na Internet é, inclusive, financiado pelo próprio grupo, enquanto que o da KBC foi financiado por fundos europeus. Estes dois exemplos de boas práticas também poderão contribuir, pois, para a solução de alguns problemas que resultam da relação entre membros do CEE e outros trabalhadores.

Já mencionado anteriormente, o papel das novas formas de TIC é cada vez mais decisivo (Vallejo e White, 2002). Reportando-se ao CEE do grupo General Motors (GM), Whittall, Knuden e Huijgen (2009: 175176) salientam a importância da rede de comunicação permanente entre as 17 fábricas europeias do grupo GM, a qual seria impensável sem o recurso às TIC. A rapidez de comunicação possibilitou ao CEE responder às situações atempadamente à medida que elas foram surgindo, possibilitando um nível de transparência e de comunicação regular essencial para reforçar a confiança e os laços entre os delegados do CEE com tradições representativas muito distintas e que, geograficamente, se encontram dispersos. Um fator decisivo para o sucesso da rede foi também o facto de os representantes terem percebido o potencial associado às novas formas de comunicação eletrónica. No caso do CEE da GM este ponto parece 
ter sido entendido pelos principais atores dentro do CEE, que apostaram num fluxo constante de informação entre delegados e entre reuniões. Um desenvolvimento importante consistiu no boletim informativo (newsletter) mensal. A ideia inicial era lançar um boletim informativo que envolvesse todas as fábricas do grupo e que oferecesse uma perspetiva global dos acontecimentos, com informações reunidas pelos peritos do CEE da fábrica da GM em Russelsheim, na Alemanha. No entanto, em parte por questões de tempo, esta ação passou a ser dominada pela Alemanha, Reino Unido e Bélgica. Não só o boletim informativo se revelou incapaz de dar uma perspetiva global de todas as fábricas europeias, mas também passou a ideia de que o CEE era controlado por representantes de apenas alguns países, em particular os alemães. Como forma de incrementar a qualidade da informação disponibilizada, assim como aumentar o empenhamento de cada uma das fábricas para o boletim informativo, foi decidido criar um "boletim informativo contínuo", que informe permanentemente a rede do CEE dos acontecimentos à medida que eles vão acontecendo. Este novo procedimento tem várias vantagens, uma das quais é "obrigar" as fábricas a ser mais responsáveis.

Como forma de exemplificar o sucesso da utilização das TIC pelos CEE, Whittall, Knuden e Huijgen (2009: 176-178) reportam-se ao caso do encerramento da fábrica da GM na Azambuja, em Portugal, no final de 2006. Apesar de não ter sido possível evitar o seu encerramento, o CEE negociou um conjunto de compensações financeiras (redundancy package) bastante favorável aos trabalhadores despedidos (240\% a mais do que os trabalhadores teriam direito em termos legais). O CEE envolveu-se de forma particular na tentativa de evitar o encerramento da fábrica: foi delineada uma estratégia de seis semanas, com três níveis potenciais de ação que cada fábrica do grupo poderia escolher, sendo que o nível 1 implicaria o recurso a 1 dia de greve. Foi decidido que não haveria apenas um dia de ação simultâneo em todas as fábricas europeias da GM, mas rotativo, com cada uma das fábricas a optarem por um nível em cada dia. Esta abordagem teve o mérito de, por exemplo, manter o nome da GM nos media durante seis semanas. O CEE recorreu ao uso da Internet para manter informadas todas as fábricas do grupo sobre os 
acontecimentos à medida que iam ocorrendo. ${ }^{42}$ Ao longo de um período de cerca de 10 anos, o CEE da GM conheceu uma evolução enorme, tendo vindo a configurar-se como uma "rede coordenadora virtual" (Pulignano apud Whittall, Knuden e Huijgen, 2009: 177), que assegura a troca e a compilação de informação de forma a facilitar a ação coletiva para além das fronteiras nacionais. Os delegados estabeleceram uma rede complexa de comités criados para potenciar o maior envolvimento dos representantes no e com o CEE, assim como melhorar o seu trabalho. Como consequência, o CEE da GM possui duas qualidades fundamentais: experiência e democracia.

Também o CEE dos Deutsche Post foi dinamizado pelo uso das TIC (Whittall, Knuden e Huijgen, 2009: 178-179). Criado em 2003 depois da privatização dos Deutsche Post e da sua aquisição pela DHL, é composto por 52 representantes, possui um comité executivo composto por quatro membros e quatro substitutos. O CEE dos Deutsche Post funciona em rede, com ligações permanentes entre os subcomités especializados e grupos de trabalho criados. As comunicações dentro do CEE têm por base um acordo que concede a todos os membros acesso gratuito a telefone, fax, fotocópias, Internet e conta de e-mail pessoal. Os representantes estão autorizados a utilizar o tempo que acharem necessário para as atividades relacionadas com o CEE e, quando eleitos, recebem formação em novas tecnologias e em línguas. Uma característica particular do acordo deste CEE teve um grande impacto na sua identidade e capacidade de comunicação: o facto de que nenhum país poder ter mais do que oito representantes no CEE constituíu uma salvaguarda da democracia interna do CEE.

\subsection{A questão da formação}

O papel da formação dos representantes em CEEs é igualmente decisivo para o seu bom funcionamento. Como refere Le Douaron (2008: 59-60),

\footnotetext{
42 Para uma análise do "caso GM-Azambuja", cf. ainda Costa e Araújo (2007c: 23-25) e Costa (2009a: 217-220). Para um olhar sobre o CEE da GM enquanto "comunidade de risco", cf. Fetzer (2008).
} 
uma formação adequada permite aos representantes dos trabalhadores nos CEEs: familiarizarem-se com os vários sistemas de representação de trabalhadores existentes nos CEEs e terem consciência de como as diferenças culturais podem influenciar as expectativas dos representantes de outros países; ultrapassar dificuldades de comunicação devido a diferenças ao nível linguístico e diferenças culturais, assim como tradições de representação diversas; identificar campos de comunicação e cooperação com outros representantes; desenvolver uma estratégia de comunicação e informação entre trabalhadores e CEEs; reunir e disponibilizar a colegas de outros países determinado tipo de recursos que os órgãos de representação nacionais possam ter desenvolvido (competência técnica financeira em França, co-gestão na Alemanha, etc.). Estimando-se que os CEEs existentes incorporam mais de 15.000 representantes de trabalhadores no EEE, imagine-se o impacto que isso teria para os representantes de trabalhadores se todos os acordos de CEEs previssem ações de formação.

Como complementa Stanzani (2008: 62-63), melhor formação significa maior liberdade, maior capacidade de expressão e de discussão dos assuntos e maior coesão. Nos CEEs, a coesão tem um papel fundamental pois ela não significa uniformidade de pensamento. Coesão significa ter a possibilidade de seguir um programa comum, sabendo que existe uma realidade, um interesse coletivo que é preciso partilhar. Ora, no quadro dos processos de formação é necessário consolidar os vários níveis de conhecimento e todas as ferramentas e métodos disponíveis de forma a conseguir duas coisas: primeiro, avaliar a capacidade para preparar o trabalho dos CEEs da melhor forma possível; segundo, ajudar a preparar o trabalho dos CEEs da forma mais correta possível, reunindo informação e aprendendo a interpretá-la e comparando dados. Sabe-se que dois terços dos membros dos CEEs não tiveram acesso a qualquer espécie de formação ou só tiveram uma formação muito incipiente. A formação para os membros dos CEEs deve ser uma targeted training. Por exemplo, a formação sindical em todos os níveis deverá saber utilizar a experiência dos CEEs como um exemplo, embora ainda subsista uma tendência para os cursos de formação dados pelas estruturas sindicais ao nível nacional não integrarem a experiência dos CEEs. 
É um facto que os representantes do CEE são, por vezes, confrontados com um grau de hostilidade por parte de membros de outros países que não o seu. Além disso, uma interpretação incorreta das suas funções e competências no CEE poderão causar alguma desconfiança nos outros trabalhadores do grupo. Os representantes são muitas vezes vistos como cúmplices das decisões tomadas pelas administrações, em especial quando estas decisões implicam a redução dos postos de trabalho num país diferente. As questões da confidencialidade invocadas em determinados assuntos contribuem para adensar as desconfianças e a incompreensão. Daí e importância acrescida em reforçar o papel da formação, como recorda Beinaert (2006: 11) a propósito do grupo Suez, grupo industrial e de serviços que desenvolve soluções sustentáveis nas áreas da eletricidade, gás, serviços energéticos, água e tratamento de resíduos. Neste grupo, os membros do CEE dispõem de um período de formação de cinco dias quando iniciam funções. A formação é ministrada pelo departamento de formação do Instituto Sindical Europeu e inclui um conhecimento do grupo, da atividade e da situação económica, legislação social europeia e práticas empresariais.

\subsection{Processos de reestruturação empresarial}

Num inquérito aplicado em 2005 por Jeremy Waddington cerca de 80\% dos representantes inquiridos afirmavam ter passado por reestruturações empresariais nos últimos 3 anos. No entanto, somente $24,2 \%$ dos mesmos haviam sido informados dessas reestruturações antes das decisões terem sido tomadas pelas administrações. Apenas $0,8 \%$ dos representantes dos CEEs inquiridos acreditava na capacidade dos CEEs para influenciarem as decisões das administrações sobre reestruturações. As principais queixas apresentadas eram as seguintes: deficiente qualidade da informação prestada pela administração e a falta de um período de tempo adequado para os CEEs prepararem uma opinião sustentada quando o assunto lhes era apresentado (Waddington apud Beirnaert, 2006: 20).

O que um estudo da Fundação Europeia para a Melhoria das Condições de Vida no Trabalho constatou a propósito das reestruturações foi 
que existe uma enorme variedade de práticas dos CEEs nesta área, mas são poucos os órgãos que conseguiram ter uma influência decisiva nos processos de reestruturação transnacional empresarial. Aliás, a informação empírica disponível sobre o envolvimento dos CEEs nos processos de reestruturação internacional mostra uma imagem muito semelhante àquela que nos é dada através da análise do conteúdo dos acordos. A maioria dos CEEs trata das questões ligadas à reestruturação transnacional das empresas na reunião anual plenária assim como nas reuniões extraordinárias convocadas para tratar de assuntos específicos ligados aos processos de reestruturação. $\mathrm{Na}$ maioria dos casos, o papel dos CEEs parece ser fundamentalmente de comunicação ou "consulta" no sentido que lhe atribuiu a Diretiva, com a administração dando informação e os representantes dos trabalhadores colocando questões ou expressando os seus pontos de vista e preocupações. Parece evidente que somente uma minoria dos CEEs conseguiu ir para além deste nível de impacto e teve efetivamente influência na decisão de reestruturação tomada (Eurofound, 2008: 9-10). Além disso, considera-se não haver registo de casos onde o CEE tenha influenciado materialmente uma decisão estratégica de uma empresa em reestruturação. O que, aliás, não é de todo surpreendente uma vez que os CEEs não foram criados para serem órgãos decisores ou substitutos dos conselhos de administração das empresas (Eurofound, 2008: 11).

Os processos de reestruturação empresarial anunciam transformações de vulto que podem ocorrer numa empresa e comportam fenómenos diversos como a racionalização da produção entre fábricas, a deslocalização da produção, dentro e fora da UE, novos investimentos produtivos, downsizing através da mudança tecnológica (por exemplo no setor dos serviços financeiros, downsizing através de mudanças na organização do trabalho, outsourcing, etc). Necessariamente, constituem, pois, um pretexto para conduzir à ação, como recordam Valejo e White (2002: 44) a propósito da Unilever. Um problema local pode ser resolvido combinando coordenação local e internacional e mobilização. Por exemplo, começou a circular na Unilever um rumor de que a empresa pretendia encerrar uma das suas fábricas em Espanha. Os sindicatos presentes na fábrica 
mobilizaram-se com greves e protestos aos quais se juntaram políticos e autoridades locais, contando ainda com a cobertura mediática da imprensa local. O CEE também esteve envolvido e foi convidado em bloco a visitar a fábrica. Como resultado de tudo isto, a empresa foi obrigada a emitir uma declaração dizendo que nunca tinha sido sua intenção fechar a fábrica. Este exemplo mostra algumas coisas importantes: os sindicatos podem conseguir melhores resultados quando agem por antecipação e são pró-ativos, quando se mobilizam localmente e constroem alianças com políticos locais e com a imprensa. Mas os resultados serão ainda melhores quando conseguem combinar tudo isto com a mobilização ao nível internacional, neste caso com o envolvimento do CEE. Finalmente, "trazer o CEE até às pessoas" significa que os trabalhadores têm uma ideia muito mais clara do que é o CEE, quem são os seus membros e de que forma lhes pode ser útil.

Apesar de os direitos dos CEEs estarem formalmente limitados à informação e consulta, mais recentemente houve vários casos de um envolvimento mais abrangente por parte destes órgãos europeus de representação de interesses. Desde o final da década de 90 houve um número de casos de CEEs que participaram em processos de reestruturação transnacionais com algum grau de sucesso. Carley (2001) apresenta quatro casos: Danone, Deutsche Bank, Ford, General Motors. Nestas empresas, o CEE teve uma função negocial no quadro de processos de reestruturação, e em duas outras (Vivendi, SLdE) teve um papel de grande influência ao nível das estratégias de globalização e expansão das empresas.

Os casos apresentados com algum detalhe são (na indústria automóvel) a General Motors e a Ford e (na indústria de eletrodomésticos) a Electrolux e a Whirlpool, onde os CEE tiveram algum sucesso no desenvolvimento de atividades autónomas que influenciaram decisões estratégicas das empresas em causa. Em alguns destes casos há que realçar o papel dos sindicatos, em concreto da Federação Europeia de Metalúrgicos (FEM) na coordenação de ações ao nível europeu, cujo desfecho foi favorável aos representantes dos trabalhadores e consequentemente aos CEEs em causa. Neste âmbito, Volker Telljohann (2007: 153) faz questão de acentuar o processo de aprendizagem que os próprios sindicatos têm vindo 
a fazer ao longo dos últimos anos sobre os CEEs. Pode observar-se que não só os CEEs pedem cada vez mais o apoio dos sindicatos, como os próprios sindicatos estão progressivamente a reconhecer a utilidade dos CEEs como fontes de informação e, por vezes, como uma plataforma para a coordenação de nível europeu. Os CEEs podem servir para os sindicatos organizarem ações de âmbito europeu como aconteceu no caso da Ford, GM, Fiat, Electrolux e Whirlpool, onde os sindicatos, neste caso a FEM, convocou mobilizações em resposta a escolhas estratégicas das administrações das empresas.

O já referido caso da GM é igualmente destacado por Beirnaert (2006: 23-27), como uma das poucas exceções à má prática generalizada de informação e consulta inadequadas aos CEE em casos de reestruturações. Na GM houve consulta efetiva do CEE antes da tomada de decisão em vários processos de reestruturação, ao longo dos últimos anos. A negociação coletiva ao nível europeu sobre determinados planos de reestruturação na GM e a negociação de acordos tendentes à implementação das decisões tomadas quase que se tornaram um processo auto-evidente nesta empresa. Em 2004, por exemplo, o CEE da GM e a administração europeia do grupo assinou um acordo-quadro europeu para acompanhar uma iniciativa de reestruturação da empresa que implicava a perda de $\mathbf{1 2 . 0 0 0}$ postos de trabalho, um pouco por toda a Europa, e que tinha provocado várias greves na fábrica alemã de Bochum. Depois da GM Europa ter anunciado, em outubro de 2004 , um programa vasto de reestruturações, o CEE decretou um Dia de Ação (Day of Action) para pressionar a administração a encetar negociações conjuntas para um acordo quadro que abrangesse todas as fábricas. As negociações levaram à assinatura de um "restructuring framework" com a participação do CEE da GM, conhecido como European Employees Forum. Como em quase todos os processos de reestruturação, este da GM está ligado à temática da responsabilidade social das empresas e aos códigos de conduta. O CEE da GM conseguiu chegar a um acordo que empurrou a GM-Europa para um quadro de responsabilidade social. Importante também neste caso foi o envolvimento da FEM. Todo o processo de reestruturação foi acompanhado por um grupo de coordenação sindical da FEM, grupo esse que melhorou a coordenação 
e a eficiência do CEE. No caso das reestruturações na GM o CEE teve um papel mais abrangente do que aquele que a Diretiva lhe confere.

Em conclusão, o acordo-quadro de 2004 na GM não impediu a perda de 12.000 postos de trabalho na GM-Europa mas conseguiu fazer com que o processo em si não seguisse para o encerramento de fábricas e para despedimentos forçados (sem garantias reais de que isso não acontecesse no futuro, o que de facto aconteceu, designadamente com a fábrica em Portugal em 2006). De acordo com a FEM, o acordo a que se chegou criou condições para que as mudanças quando ocorressem se processassem de uma maneira socialmente mais aceitável, minimizando as consequências para os trabalhadores, para as suas famílias e para a comunidade, em geral”. Afinal, como referem Da Costa e Rehfeldt (2007), estes vários acordos-quadro (realizados desde meados de 2000) 43 da GM acabaram por ser reveladores de uma certa força das estratégias sindicais coordenadas a nível europeu, mas igualmente da fragilidade dos acordos passados, sobretudo tendo em conta as dificuldades económicas da empresa e a ausência de validade jurídica dos acordos de empresa europeus.

Um outro exemplo de boas práticas relacionados com os processos de reestruturação prende-se com o Grupo Axa (seguros), que criou o seu CEE em 1996 e cujo acordo já continha algumas determinações interessantes, como recorda Beirnaert (2006: 27-29). Por exemplo, foi criado um comité restrito que reuniria uma vez por mês com o responsável dos recursos humanos da empresa. A empresa descreve o CEE como tendo um "papel extenso", pioneiro nas relações sociais, cujas atribuições vão para além das determinadas pela Diretiva. O acordo de 1996 foi renegociado em 2002 de modo a dotar o CEE do direito de informação em tempo útil quando ocorressem reestruturações cujas consequências previsivelmente afetassem metade dos trabalhadores da empresa num determinado país. Em 2005 foi assinado um acordo sobre diálogo social e no caso de haver reestruturações no grupo Axa estabeleceu-se um processo de consulta intermédio que envolve: uma troca de pontos de vista anterior ao processo

43 Para uma síntese dos conteúdos dos acordos-quadro da GM realizados desde 2000, cf. Da Costa e Rehfeldt (2007). 
de tomada de decisão que estabelece orientações gerais; preparação de um plano de ação; consulta sobre a aplicação da decisão e o seu impacto local; e, finalmente, a implementação e decisões futuras. O acordo também menciona alguns temas específicos sobre os quais o CEE deverá ser informado e consultado, tais como: aprendizagem ao longo da vida, saúde, segurança e igualdade de oportunidades.

Apesar de, como se disse acima, não haver registo de casos onde o CEE tenha influenciado materialmente uma decisão estratégica da empresa sobre reestruturação, há alguns casos em que os CEEs estiveram envolvidos nesse processo de decisão e que tiveram influência sobre a forma de implementação da decisão de reestruturação. Dois deles são os do Group4Falck e da Ford (Eurofound, 2008: 11), nos quais houve influência do CEE na decisão tomada pela empresa.

O CEE do Group4Falck (Dinamarca, serviços de segurança) conseguiu exercer influência sobre a decisão da companhia se fundir com a empresa com sede no Reino Unido chamada Securicor. Numa reunião ordinária do CEE do Group4Falck com os elementos sénior da administração da empresa, em abril de 2004, o tema central foi a fusão prevista com a empresa Securicor. Os representantes dos trabalhadores conseguiram impor à administração algumas condições caso a fusão se concretizasse. Segundo um representante dinamarquês do CEE, a reunião revelou-se favorável ao lado dos trabalhadores tendo a administração concordado com várias propostas apresentadas. Uma dessas propostas foi a de que os representantes dos trabalhadores dos países sede das empresas (Dinamarca e Reino Unido) deveriam estar envolvidos nas negociações de carácter mais específico relativas à fusão.

O CEE da Ford na Europa foi pioneiro no desenvolvimento de um papel negocial com a administração da empresa, e concluiu três acordos conhecidos, dois dos quais relativos a iniciativas de reestruturação da empresa (o terceiro assinado em 2003 abrangia "princípios de responsabilidade social e direitos sociais”). Em 2000, foi assinado um acordo sobre as consequências do estatuto do trabalhador (incluindo salários e condições), representação laboral e sobre o spin-off da Ford em resultado da divisão de componentes da Visteon. Em 2004, foi concluído um acordo 
relativo à segurança no emprego no contexto dos planos da empresa para atingir "sinergias nas operações internacionais" em várias áreas, em particular na área de desenvolvimento do produto e aquisições (EWCB apud Eurofound 2008: 11).

Assinale-se, pois, que alguns CEEs conseguiram fazer com que questões como o emprego e algumas regalias sociais fossem salvaguardados nos processos de reestruturação (exemplos: Aventis, Bayer, Electrolux, Group4Falck, Henkel e Whirlpool). Isto aconteceu na maior parte das vezes de uma forma informal que é difícil de contabilizar, embora exista um número de casos conhecidos (pelo menos 19) em que a administração e o CEE chegaram a acordo escrito sobre matérias relacionadas com a reestruturação da empresa (Eurofound 2008: 11).

\subsection{Temas "além" da Diretiva dos CEEs}

Tem-se vindo a verificar uma tendência entre as multinacionais para a assinatura de "acordos globais", "acordos-quadro internacionais" e "códigos de conduta" com os representantes dos trabalhadores em mais do que um país (Costa, 2011). Estes acordos comprometem a empresa, e por vezes fornecedores e parceiros de negócios, a observar determinadas normas e princípios nas suas operações comerciais pelo mundo (ou região) relacionadas com os direitos dos trabalhadores, emprego e outras áreas da responsabilidade social das empresas (RSE). Os CEEs têm vindo também a desenvolver um papel ao nível da facilitação da troca de informação sobre determinados assuntos como as condições de trabalho, tempo de trabalho, práticas de emprego, etc., promovendo a europeização da negociação coletiva ao nível das multinacionais. Mas coloca-se a seguinte questão: até que ponto é que os CEEs devem ou não ter esse papel? Onde os representantes conseguiram ter um papel ao nível da negociação e da implementação de acordos-quadro, a relação com a administração local assumiu uma dimensão nova capaz de garantir que os acordos firmados fossem aplicados localmente. Este papel pode ser assumido pela administração central, pelo comité restrito, pelos representantes locais ou 
pelo próprio CEE. Segundo apurou Jeremy Waddington num inquérito aplicado em 2005, mais de metade dos respondentes não sabiam se o acordo do CEE respetivo estabelecia a conclusão de textos conjuntos, $26,9 \%$ afirmaram que sim e 34\% que não. Quanto aos temas abrangidos nos acordos, a maior parte dizia respeito a saúde e segurança, promoção da igualdade, formação e mobilidade da força de trabalho (Waddington apud Beirnaert, 2006: 35).

A negociação e a implementação de códigos de conduta começam a ser temas de discussão também para os CEEs. Este papel negocial não está consignado na Diretiva dos CEE, daí muitos se questionarem sobre a sua legitimidade e competência na discussão destas matérias. Ora, se os CEE conseguirem ter um papel negocial ao nível dos códigos de conduta e dos acordos-quadro sobre RSE, as consequências das reestruturações sobre o emprego poderão ser consideradas uma parte lógica disso. Todas as Federações Sindicais Europeias (FSEs) desenvolveram estruturas para coordenar as ações dos CEEs com os seus sindicatos filiados. Estas estruturas estiveram envolvidas na criação de CEEs e como tal envolveram-se no debate sobre as atribuições dos CEEs. Aquilo que os CEEs devem conseguir fazer ou lutar por atingir para além da mera informação e consulta prende-se com: solidariedade nos processos de reestruturação, acordos de empresa ao nível europeu, coordenação ao nível da negociação coletiva ou direitos de co-gestão. Porém, não existe unanimidade neste debate, uma vez que as posições divergentes têm na sua origem experiências nacionais muito distintas. No entanto, o que fica claro é que as FSEs estão todas empenhadas na expansão das funções tradicionalmente atribuíveis aos CEEs, estando por saber se conseguirão desenvolver esse papel ou se terão os recursos para o fazer de forma mais consolidada no futuro.

De um conjunto de exemplos de CEEs que vêm desenvolvendo esforços em ir além da estrita informação e consulta e que são analisados por Beirnaert (2006: 37-43), destacam-se, entre outros, os da Suez, Total, EADS, Rochling, BMW ou Lafarge.

No grupo Suez (setor energético), cujo CEE é de 1995, foi assinada em 1998 uma carta social internacional pela administração e pelo CEE 
onde ficaram consignados os esforços da empresa em relação ao retraining and redeployment de trabalhadores afetados por reorganizações e reestruturações. Esta carta social é geral e "declaratória" e menciona: igualdade de oportunidades, combate à exclusão social, desenvolvimento pessoal, emprego, contribuição dos trabalhadores para o desenvolvimento da empresa, ambiente de trabalho, diálogo social e consulta social, saúde e segurança, proibição de trabalhos forçados e emprego infantil. Outra evidência desta preocupação social no grupo Suez foi a criação de um "observatório social internacional" (2000), um fórum de debate que envolve a administração, os representantes dos trabalhadores e participantes externos (políticos e sindicalistas, por exemplo). Este órgão procura debater o impacto da globalização em áreas como o diálogo social, a reorganização do trabalho e as implicações sobre os trabalhadores, constituindo um ambiente fértil e inovador em termos de contactos com o CEE do grupo.

Em 2005, na Total, a administração sénior e três FSEs assinaram um acordo de abrangência europeia sobre igualdade de oportunidades que dá seguimento ao processo de códigos de conduta iniciado em 2004.

A EADS (empresa líder na construção aeroespacial, defesa e serviços relacionados) tem um abrangente CEE e três sub-comités. Cada um desses três comités conta com a participação de um membro do CEE e de um membro adicional que representa os trabalhadores. Reúne, no mínimo, duas vezes por ano com a administração e pode recorrer a peritos externos, se assim o entender. Em 2005 foi assinado um acordo quadro internacional pelo CEE, a direção da EADS e as Federações Europeia e Internacional de Metalúrgicos. A negociação deste acordo contou com a participação ativa do CEE que se revelou um parceiro fundamental para a sua implementação: "nos países onde a EADS opera, os representantes sindicais no conselho de empresa poderão informar a administração central, oralmente ou por escrito, de qualquer incumprimento de uma ou mais normas constantes do acordo. A administração da EADS deverá tomar todas as medidas para eliminar essa brecha nos princípios acordados levando a plenário do CEE as medidas adotadas. O CEE poderá sugerir medidas corretivas de modo a assegurar o cumprimento dos princípios estipulados. Em situações de 
conflito, o processo arbitral deverá ser acordado entre o chefe dos recursos humanos da EADS e o CEE" (Beirnaert, 2006: 39).

A Lafarge (líder mundial em materiais de construção, sobretudo em cimento) constituiu o seu CEE em 1994, antes da transposição da Diretiva. Tal como a Total, também subscreveu um acordo sobre Responsabilidade Social das Empresas e Relações Laborais Internacionais, em 2005, com a participação de várias Federações Sindicais Internacionais. A Lafarge compromete-se a agir em conformidade com os princípios constantes na International Labour Organization Declaration on Fundamental Principles and Rights at Work, a ILO Tripartite Declaration of Principles Concerning Multinational Enterprises and Social Policy, o Global Compact das Nações Unidas, entre outras. Em termos de relações laborais e adicionalmente aos princípios de liberdade de associação e direitos de negociação coletiva, a Lafarge compromete-se ainda a envolver diretamente os seus trabalhadores no futuro do grupo através de um diálogo social amplo. Reconhece aos trabalhadores o direito de serem representados por trabalhadores eleitos e/ou organizações sindicais. Apesar de ter o CEE constituído há já bastante tempo, este não é/foi uma parte envolvida nas negociações nem na assinatura de acordos quadro internacionais. Conclui-se que o acordo assinado sobre RSE tem uma aplicação internacional, sem referência específica ao nível europeu.

Um tema adicional emergente prende-se com a igualdade de representação e participação entre homens e mulheres no quadro dos CEEs. Como demonstraram Costa e Araújo (2009: 102), a propósito dos representantes portugueses em CEEs, 73,8\% dos representantes são do sexo masculino e apenas $26,2 \%$ são do sexo feminino. Esta é, aliás, uma situação comum a grande maioria dos CEEs, sendo a "masculinização" destas instituições o reflexo/confirmação da sub-representação das mulheres que igualmente está patente nos cargos de decisão das principais organizações representativas de trabalhadores: as organizações sindicais. ${ }^{44}$ Não obstante o reconhecido défice de presença feminina nos CEEs, Marina

44 Para uma discussão mais ampla da problemática da igualdade entre mulheres e homens no trabalho e no emprego em Portugal, cf. Ferreira (org.) (2010). 
Monaco (2007), apoiando-se na base de dados da Social Development Agency: www.sda-asbl.org, reporta-se a um conjunto de boas práticas neste domínio, ao analisar a questão da igualdade de género com base no estudo de 755 acordos de CEEs em vigor e em 90 textos conjuntos (joint texts) concluídos entre os CEEs e as administrações das empresas.

A autora constata que o princípio da igualdade de género se encontra em apenas 92 acordos (ou 12\%) dos 755 considerados. A maior parte desses 92 acordos, mais precisamente 76, considera a questão da igualdade de oportunidades como um possível tópico de análise, entre outros tópicos de informação e consulta dos trabalhadores. Apenas 10 acordos evidenciam a questão da igualdade como um critério ou norma para um equilíbrio laboral entre os trabalhadores no funcionamento da empresa. Porém, o número de empresas que retêm os dois aspetos supra-citados, isto é, o âmbito e a composição dos representantes de trabalhadores é ainda mais reduzido (6).

Em comparação com outras provisões mais genéricas sobre o emprego enquanto objeto de informação e consulta, a igualdade de género é claramente mais baixa: apenas $10 \%$ dos acordos examinados contêm uma referência neste sentido de entre as competências atribuídas aos CEEs, ao passo que a maioria dos acordos faz menção explícita à questão da saúde e segurança e muitos acordos fazem também referência às condições de trabalho e à formação (Monaco, 2007: 10). Na verdade, as referências à igualdade de género aparecem sempre no final de uma lista explicativa de assuntos ou mesmo depois das disposições supletivas relativas à informação e consulta, ou inclusive ainda em anexos. Ou seja, a referência às questões da igualdade de género é recorrentemente uma questão formal, colocada apenas para responder às solicitações de (poucos) membros do Grupo Especial de Negociação (GEN).

Por outro lado, e tendo por base um estudo de Jeremy Waddington sobre a visão dos representantes dos CEEs a propósito desta questão, apenas $2 \%$ de representantes em CEEs elegeram a questão da igualdade de oportunidades como a mais importante na agenda das reuniões dos CEEs. Na verdade, questões como o encerramento de empresas, as estratégias corporativas e investimentos, bem como a situação económica e 
financeira da empresa são olhadas preferencialmente. Ainda assim, quase 21\% dos representantes em CEEs mencionaram que gostariam de receber mais instrução sobre a igualdade entre géneros de modo a melhorar o trabalho dos seus CEEs, o que é tanto mais significativo quanto se constatou que $84 \%$ dos respondentes eram do sexo masculino (Waddington, apud Monaco, 2007: 10-11).

Apesar destas dificuldades é possível reportar casos de boas práticas, mesmo que não seja fácil encontrar muitos relatórios sobre eles. Assim sendo, Monaco (2007: 11-12) reporta-se ao acordo da Dexia (setor financeiro), nos termos do qual refere que o CEE incorpora um comité de assuntos sociais, o qual é responsável, entre outras questões, pela igualdade de oportunidades. Por sua vez, no caso da Gucci (setor têxtil) o acordo prevê a possibilidade de criação de grupos de trabalho específicos (com duração limitada ou ilimitada), cuja missão passa por debater tópicos específicos como o emprego, a formação, a segurança e a igualdade de oportunidades. Estas iniciativas são submetidas a plenário do CEE, de modo a serem examinadas pelos representantes dos trabalhadores e pela administração nos níveis nacional e local para posterior deliberação. Por outro lado ainda, na Unilever (industria alimentar) o acordo do CEE estabelece a "situação da mulher" como sendo uma das competências do CEE, o que não é alheio à composição da mão de obra da empresa, fortemente feminizada. A questão da progressão na carreira ou a introdução de horários de trabalho flexíveis são algumas das matérias contempladas no acordo do CEE. Neste CEE foi igualmente delineado um plano com vista a aumentar a representação feminina nos níveis mais elevados da organização. Por fim, na Ericsson (setor metalúrgico e outros serviços), cujo acordo não mencionada as questões de género, foi publicada em 2005 uma brochura onde se sublinha a situação do emprego das mulheres, a sua formação profissional e qualificações, as suas carreiras profissionais e questões relacionadas com a proteção na maternidade e a articulação trabalho/vida familiar. As representantes femininas do CEE foram chamadas a pronunciar-se sobre um conjunto de medidas destinadas a avaliar a posição das mulheres na empresa e a contribuir com ações destinadas a reforçar a igualdade de género, tais como um encontro com um especia- 
lista em igualdade de género no âmbito do CEE e um orçamento anual para atividades de promoção da igualdade e dinamização da rede entre delegadas no CEE.

Numa pesquisa conduzida pela Confederação Europeia de Sindicatos (CES) em 2006, foi pedido às FSEs nela filiadas que fornecessem dados sobre a composição setorial dos CEEs. Constatou-se, porém, que nenhuma delas tinha vindo a monitorizar este assunto, pelo que não se apurou qual o peso feminino nos CEEs. A entrevista com alguns representantes das FSEs (em especial de setores com uma mão de obra mais feminizada) permitiu, ainda assim, obter alguns dados sobre a expressão da presença de mulheres em CEEs. Na European Trade Union Federation Textiles existem cerca de $5 \%$ de mulheres coordenadoras, ao passo que na European Federation of Building and Woodworkers esse valor ronda os 8\% e na European Federation of Food, Agriculture \& Tourism Trade Unions os $12 \%$. E quando se olha para os comités restritos dos CEEs esse valor é ainda mais baixo. Ainda assim, um exemplo surpreendente a este respeito é o caso da Sanofi-Aventis (setor químico), pois o conselho restrito (CR) que resultou da fusão daquelas duas empresas em 2005 apresenta uma composição maioritariamente feminina. Apesar de o acordo não conter nenhuma cláusula sobre a igualdade de oportunidades e a representação feminina, e apesar de não ser mencionada a presença de mulheres por parte da representação da administração, o que é facto é que o CR é composto por 1 homem e 4 mulheres, sendo também uma mulher a chairperson do CR.

Por fim, Marina Monaco (2007: 19-23) dá-nos ainda testemunho mais aprofundado do "caso Areva" (grupo pertencente ao setor energético), tendo a empresa Areva assinado com a Federação Europeia de Metalúrgicos/European Metalworkers' Federation (FEM) um acordo-quadro sobre a igualdade de oportunidades dentro do grupo. Não se tratou de uma mera declaração de intenções, mas antes de um compromisso efetivo por parte das partes subscritoras no sentido de melhorarem os padrões relativos à igualdade de oportunidades entre homens e mulheres, assim como a integração profissional dos mais incapacitados em todas as estruturas do grupo. $\mathrm{O}$ acordo estabelece indicadores relevantes como forma de avaliar 
os progressos alcançados, salientando-se o propósito das partes em tomar o perímetro europeu como ponto de referência para o desenvolvimento de uma política pró-ativa de igualdade de oportunidades.

Fundado em 2003, o CEE do grupo Areva é composto por 33 representantes, representando 42.000 empregados em 13 países europeus, reunindo-se duas vezes por ano em sessões plenárias. O CR é composto por 7 elementos provenientes de 3 países, reunindo-se 4 a 6 vezes por ano. A realização do acordo-quadro entre o CEE e a FEM ocorreu num contexto de recetividade por parte da administração da empresa, com quem, aliás, já fora celebrado um acordo de aprendizagem ao longo da vida entre o CEE e a administração em resultado de uma frutuosa colaboração entre ambos. E refira-se que a empresa dispõe ela própria de um modelo interno - a Areva Way - que é uma política interna definida de molde a que as entidades do grupo possam medir as suas próprias performances anuais em matéria de RSE. Assim, a Areva Way constitui um instrumento complementar para interpretar o acordo-quadro europeu, tanto mais que muitos indicadores que constam deste acordo já se encontram presentes no Areva Way. Por outro lado, ainda no quadro da política interna da empresa, criou-se um "Fórum Mulher" que funciona do seguinte modo: 100 mulheres provenientes de várias áreas e com distintas posições reúnem-se duas vezes por ano de modo a discutir todos os temas que possam afetar $20 \%$ da força de trabalho feminina presente na empresa.

No que concerne especificamente ao conteúdo do acordo-quadro, dele sobressai a noção de igualdade de oportunidades e de tratamento entre sexos, nomeadamente: na fase de recrutamento, no acesso igual à promoção de carreira para todos os empregados, no acesso igual em matéria de salários e formação. A fase de recrutamento baseia-se nos mesmos critérios para ambos os sexos, quer quanto a critérios de seleção de competências, experiência profissional ou qualificações do candidato ao emprego. No que concerne ao desenvolvimento de carreiras, homens e mulheres devem dar os mesmos passos, ter as mesmas oportunidades de desenvolvimento de carreiras e as mesmas posições de responsabilidade. Ainda a respeito da progressão na carreira, a questão da formação profissional é considerada um elemento fundamental. Por sua vez, o 
salário igual para mulheres e homens é um dos elementos-chave da promoção da igualdade no local de trabalho, devendo como tal os diferentes componentes salariais serem avaliados numa base comum para ambos os sexos. Por fim, a conciliação entre trabalho e vida familiar está igualmente prevista em várias medidas, sendo prestada especial atenção às horas de trabalho e ao uso da licença parental tanto por homens como por mulheres em articulação com a legislação de cada país. 


\section{CAPÍTULO 3}

\section{AnÁlise SETORIAL DA CONSTITUIÇÃO DE CONSELHOS DE EMPRESA EUROPEUS EM PORTUGAL, NOS SETORES METALÚR G I C O, QUÍMICO E FINANCEIRO}

O setor metalúrgico e o setor químico são, no quadro da atuação global dos CEEs, os que apresentam um maior número de empresas em condições de constituir CEEs, assim como de CEEs efetivamente constituídos. O setor financeiro, por sua vez, ocupa normalmente a quarta posição nesse ranking, mas é aqui destacado quer por ser o único onde é possível identificar um CEE de uma empresa com sede em Portugal, quer por ser o setor mais representativo no que concerne às empresas com sede em Portugal que, apesar de não terem constituído CEEs, preenchem as condições legais para o fazer.

Em 1995 o departamento de investigação do Instituto Sindical Europeu (European Trade Union Institute for Research, Education and Health and Safety, ETUI-REHS) criou uma base de dados que se revelou fundamental para avaliar a evolução da aplicação da Diretiva nas multinacionais por esta abrangidas. Tal base, coordenada até 2006 por Peter P. Kerckhofs e Irmgard Pas, contou com a colaboração de mais de vinte Institutos e Federações Sindicais Europeias (FSEs) e passou a reunir cerca de 1.000 textos de acordos de CEEs, incorporando ainda diversas informações sobre as multinacionais: o nome das multinacionais, o país de origem, os setores de atividade, os países de operações, o envolvimento em reestruturações, fusões e aquisições, o estatuto perante a Diretiva, o estatuto dos acordos na base dos quais foram constituídos os respetivos CEEs, etc. 
Desde 2007 a referida base passou a estar disponível on-line (http:// www.ewcdb.eu/), mantendo-se a colaboração com as FSEs, mas igualmente com a Social Development Agency (SDA) (http://www.sda-asbl. org/), que disponibiliza análises e documentos adicionais. Sendo objeto de atualização periódica, a European Works Coucils Database incorpora informação sobre as multinacionais abrangidas pela Diretiva dos CEEs, bem como multinacionais que têm acordos de CEEs mas que são Sociedades Europeias. Trata-se de uma base de dados de referência quer para a EU, quer para as instituições nacionais, bem como para centros de investigação e, claro está, para estudiosos das relações laborais e dos CEEs em particular e para todos os atores de terreno interessados nas formas de participação laboral (FSEs, sindicatos, representantes nacionais de trabalhadores, membros de conselhos de empresa nacionais ou representantes de trabalhadores em CEEs).

Em paralelo aos serviços disponibilizados pela base de dados, está igualmente disponível on-line uma secção de provisões legais associadas ao funcionamento dos CEEs, bem como uma secção (com ela relacionada) de jurisprudência onde podem consultar-se casos julgados em tribunal em que CEEs estiveram envolvidos ou nos quais uma decisão produziu impacto no seu funcionamento. Num site adicional do Instituto Sindical Europeu (www.worker-participation.eu) encontra-se ainda informação sobre os CEEs no contexto mais amplo da participação dos empregados na UE.

Antes de passarmos aos dados da expressão setorial dos CEEs, importa assinalar, em termos genéricos, que em março de 2014, e segundo a European Works Councils Database (http://www.ewcdb.eu/statistics_graphs. php), existiam 975 multinacionais com CEEs, 1.053 CEEs ativos (apesar de até então terem sido criados 1.291 CEEs) e 1.824 acordos de CEEs celebrados (http://www.ewcdb.eu/list_agreements.php) ${ }^{45}$. Além disso,

45 Esta descoincidência entre o número de multinacionais que constituíram CEEs e o número de CEE efetivamente existentes resulta do facto de algumas multinacionais poderem constituir mais do que um CEE na base de mais do que um acordo. A diferença entre o número de CEEs e o número de acordos justifica-se ainda pelo facto de novos acordos serem firmados depois de fusões ou dissoluções de empresas ou devido à renegociação de alguns acordos. 
58 multinacionais estavam em negociações para a criação de CEEs e 195 multinacionais que dispunham de um CEE fundiram-se ou dissolveram-se.

Este é um panorama genérico do "estado da arte" da constituição de CEEs no Espaço Económico Europeu (EEE). Mas atente-se então no comportamento setorial dos CEEs, designadamente nos setores metalúrgico, químico e financeiro e nas empresas em que existem representantes de trabalhadores portugueses. ${ }^{46}$

\section{Multinacionais abrangidas pela Diretiva dos CEEs e países de sede das multinacionais, segundo os setores metalúrgico, quí- mico e financeiro}

Atendendo ao número de multinacionais que preenchem as condições necessárias à criação de um Conselho de Empresa Europeu (CEE) ou à instituição de um Procedimento de Informação e Consulta (PIC), agregando o setor químico, metalúrgico e financeiro, a base de dados de 2011 recenseia um total de 1.409 empresas multinacionais. Destas, aparece em destaque (e confirmando a tendência mais ampla de comportamento dos CEEs em geral) o setor metalúrgico, com 816 empresas (57,9\%), seguido do setor químico, com 452 (32,1\%), e do financeiro, com 141 empresas (10\%) (ver Quadro 1 e Gráfico 1). Deste número global, apenas uma parte regista operações em Portugal, cerca de 25\% (360 multinacionais: 200 incluem-se no setor metalúrgico, 122 no setor químico e apenas 38 no setor financeiro).

QUADRO 1 - Multinacionais, por setor de atividade

\begin{tabular}{|c|c|c|c|c|}
\hline Setores & Químico & Metalúrgico & Financeiro & Total \\
\hline Multinacionais & 452 & 816 & 141 & 1409 \\
\hline$\%$ & 32,1 & 57,9 & 10,0 & 100 \\
\hline
\end{tabular}

Fonte: European Works Councils Database 2011

46 Note-se que dados setoriais seguidamente apresentados se reportam ao ano de 2011, ainda que em 2012 e 2013 o panorama apresentado seja quase idêntico. 


\section{GRÁFICO 1}

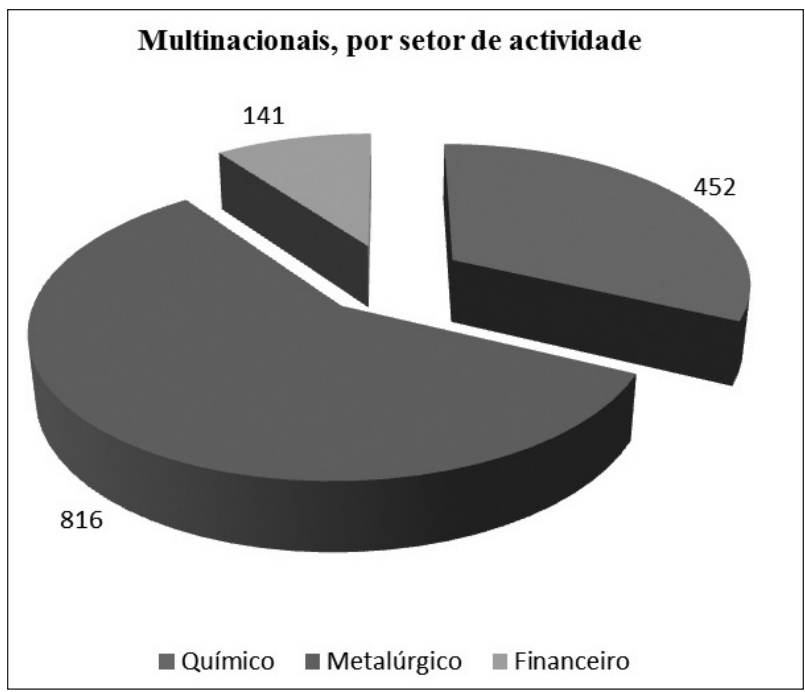

Fonte: European Works Councils Database 2011

O país da sede das multinacionais nos setores em análise que mais se destaca é a Alemanha, sendo dentro deste o setor metalúrgico.

Com efeito, com se atesta pelo quadro 2, na UE-27 a Alemanha é o país-sede que se destaca claramente pelo número de multinacionais abrangidas pela Diretiva (368), com uma grande representatividade de empresas no setor metalúrgico (248, ou seja $67,4 \%$ do total de multinacionais nos três setores). Seguem-se o Reino Unido, com 134 multinacionais abrangidas, a França com 96, e a Suécia com 68 multinacionais. Para Portugal surgem recenseadas na base de dados 5 empresas $^{47}$ nas condições de constituírem um CEE, duas pertencentes ao setor químico e três ao setor financeiro.

47 No estudo do impacto dos CEEs em Portugal abrangendo todos os setores de atividade económica, Costa e Araújo (2009: 30), tendo por base a versão de 2006 (disponível em CD-Rom) desta mesma base de dados do Instituto Sindical Europeu (embora corrigindo-a com os contactos de terreno realizados) haviam identificado 7 multinacionais com sede em Portugal abrangidas pela Diretiva. O facto de 5 dessas multinacionais pertencerem a 2 dos setores aqui em análise só reforça a importância do seu tratamento mais apurado neste estudo. 
QuAdro 2 - Países de sede das multinacionais, por setor de atividade

\begin{tabular}{|c|c|c|c|c|c|}
\hline & Países & Químico & Metalúrgico & Financeiro & Total \\
\hline \multirow{20}{*}{$\mathrm{UE}-27$} & Alemanha & 99 & 248 & 21 & 368 \\
\hline & Áustria & 11 & 14 & 4 & 29 \\
\hline & Bélgica & 16 & 21 & 3 & 40 \\
\hline & Chipre & 0 & 0 & 2 & 2 \\
\hline & Dinamarca & 12 & 17 & 1 & 30 \\
\hline & Eslováquia & 0 & 2 & 0 & 2 \\
\hline & Eslovénia & 0 & 1 & 0 & 1 \\
\hline & Espanha & 6 & 7 & 6 & 19 \\
\hline & Finlândia & 13 & 16 & 0 & 29 \\
\hline & França & 30 & 49 & 17 & 96 \\
\hline & Grécia & 0 & 2 & 1 & 3 \\
\hline & Holanda & 15 & 27 & 9 & 51 \\
\hline & Hungria & 6 & 3 & 1 & 10 \\
\hline & Irlanda & 7 & 4 & 4 & 15 \\
\hline & Itália & 17 & 27 & 9 & 53 \\
\hline & Luxemburgo & 0 & 1 & 0 & 1 \\
\hline & Polónia & 3 & 1 & 1 & 5 \\
\hline & Portugal & 2 & 0 & 3 & 5 \\
\hline & Reino Unido & 50 & 68 & 16 & 134 \\
\hline & República Checa & 2 & 1 & 0 & 3 \\
\hline \multirow{5}{*}{ EFTA } & Suécia & 16 & 45 & 7 & 68 \\
\hline & Islândia & 2 & 0 & 0 & 2 \\
\hline & Liechtenstein & 0 & 2 & 0 & 2 \\
\hline & Noruega & 6 & 10 & 3 & 19 \\
\hline & Suíça & 18 & 32 & 9 & 59 \\
\hline \multirow{16}{*}{$\begin{array}{l}\text { Resto do } \\
\text { Mundo }\end{array}$} & África do Sul & 2 & 1 & 0 & 3 \\
\hline & Austrália & 3 & 2 & 1 & 6 \\
\hline & Canadá & 6 & 7 & 1 & 14 \\
\hline & Cazaquistão & 1 & 0 & 0 & 1 \\
\hline & Coreia do Sul & 0 & 6 & 0 & 6 \\
\hline & Croácia & 1 & 0 & 0 & 1 \\
\hline & Estados Unidos & 90 & 151 & 17 & 258 \\
\hline & Hong Kong & 0 & 2 & 2 & 4 \\
\hline & Índia & 1 & 3 & 1 & 5 \\
\hline & Israel & 1 & 0 & 0 & 1 \\
\hline & Japão & 14 & 38 & 1 & 53 \\
\hline & Kuwait & 1 & 0 & 0 & 1 \\
\hline & México & 1 & 0 & 0 & 1 \\
\hline & Rússia & 0 & 1 & 1 & 2 \\
\hline & Singapura & 0 & 2 & 0 & 2 \\
\hline & Taiwan & 0 & 4 & 0 & 4 \\
\hline \multirow{2}{*}{\multicolumn{4}{|c|}{\begin{tabular}{c|c|r} 
& 452 & 815 \\
\multirow{2}{*}{ *Uma multinacional não refere o país de sede }
\end{tabular}}} & 141 & $1408^{*}$ \\
\hline & & & & & \\
\hline
\end{tabular}


Para os países da EFTA, o destaque vai para a Suíça, com 59 empresas multinacionais incluídas no âmbito da Diretiva. No Resto do Mundo, são os Estados Unidos da América (EUA), com 258 multinacionais, e o Japão, com 53, que ocupam os dois principais lugares. Em qualquer um destes países, as empresas do setor metalúrgico são predominantes.

\section{Multinacionais e Conselhos de Empresa Europeus, por setor de atividade}

Apesar de preencherem teoricamente os requisitos para a criação de um CEE, o número das multinacionais (nos três setores) que decidiu avançar nesse sentido é ainda pouco animador (cerca de 42\%, 592 empresas) tendo em conta a "idade" da Diretiva 94/45/CE48 e todo o conjunto de experiências positivas entretanto acumuladas em termos de funcionamento dos CEE e do seu impacto nas multinacionais (conforme relatado no capítulo 2). Assim sendo, o que se pode destacar em relação à aplicação da Diretiva nos três setores de atividade em análise é, em primeiro lugar, a ainda elevada percentagem de empresas que não constituíram CEEs $(56,2 \%)$ perante o número de multinacionais abrangidas (a taxa de concretização da aplicação da Diretiva) e, segundo, o reduzido número de multinacionais que se encontram em negociações tendentes à instauração de um dos mecanismos de informação e consulta transnacionais (apenas 1,6\%).

Olhando mais atentamente para os três setores de atividade em análise podemos ainda constatar o seguinte: o setor químico é aquele onde a taxa de concretização da aplicação da Diretiva é maior $(45,1 \%)$, apesar de ainda não chegar a metade do número de multinacionais abrangidas pela Diretiva, e o setor financeiro regista a maior percentagem de empresas em negociações tendentes à criação de CEEs $(2,1 \%)$ (ver quadros 3 e 4 e gráfico 2).

${ }^{48}$ Recorde-se, como ficou dito no capítulo 1, que 5.06.2011 foi a data em que formalmente expirou o prazo para a transposição da Diretiva 2009/38/CE para o direito interno dos Estados-Membros do EEE. 
QUADRo 3 - Estatuto do CEE, por setor de atividade das Multinacionais

\begin{tabular}{|l|c|c|c|c|}
\hline Estatuto do CEE & Químico & Metalúrgico & Financeiro & Total \\
\hline Com CEE & 204 & 332 & 56 & 592 \\
\hline Sem CEE & 241 & 470 & 81 & 792 \\
\hline Em negociações & 6 & 13 & 3 & 22 \\
\hline Perdeu CEE & 1 & 1 & 1 & 3 \\
\hline Total & $\mathbf{4 5 2}$ & $\mathbf{8 1 6}$ & $\mathbf{1 4 1}$ & $\mathbf{1 4 0 9}$ \\
\hline
\end{tabular}

Fonte: European Works Councils Database 2011

QUADRO 4 - Estatuto do CEE, por setor de atividade das Multinacionais (\%)

\begin{tabular}{|l|c|c|c|}
\hline \multicolumn{1}{|c|}{ Estatuto do CEE } & Químico & Metalúrgico & Financeiro \\
\hline Com CEE & 45,13 & 40,69 & 39,72 \\
\hline Sem CEE & 53,32 & 57,60 & 57,45 \\
\hline Em negociações & 1,33 & 1,59 & 2,13 \\
\hline Perdeu CEE & 0,22 & 0,12 & 0,71 \\
\hline Total & $\mathbf{1 0 0 , 0 0}$ & $\mathbf{1 0 0 , 0 0}$ & $\mathbf{1 0 0 , 0 0}$ \\
\hline
\end{tabular}

Fonte: European Works Councils Database 2011

Atendendo à constituição de CEEs por países de sede das multinacionais abrangidas pela Diretiva, verifica-se que a taxa de concretização da aplicação da Diretiva é quase sempre negativa, ou seja, o número de multinacionais que não constituíram CEEs é, na grande generalidade dos países, mais elevada do que o número daquelas que o fizeram.

Um olhar sobre os três setores em análise permite constatar oscilações no que concerne à taxa de concretização da aplicação da Diretiva por país sede das multinacionais. Para o setor químico, há nove países onde o número de multinacionais que constituíram CEEs ultrapassa o número daquelas que ainda o não fizeram, ou seja, cuja taxa de concretização da Diretiva é positiva. São eles, a Bélgica, a Finlândia, a Holanda, a Itália, o Reino Unido e a Suécia (UE - 27), a Noruega (EFTA), 
GRÁFICO 2

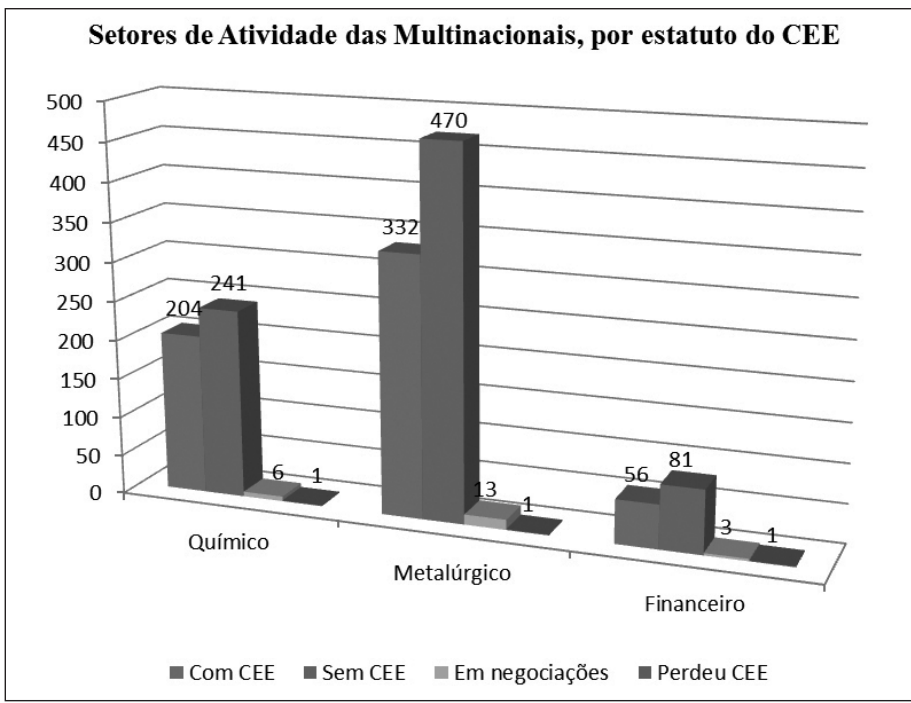

Fonte: European Works Councils Database 2011

\section{GRÁfICO 3}

Países de sede das multinacionais, por estatuto do CEE, para o setor químico

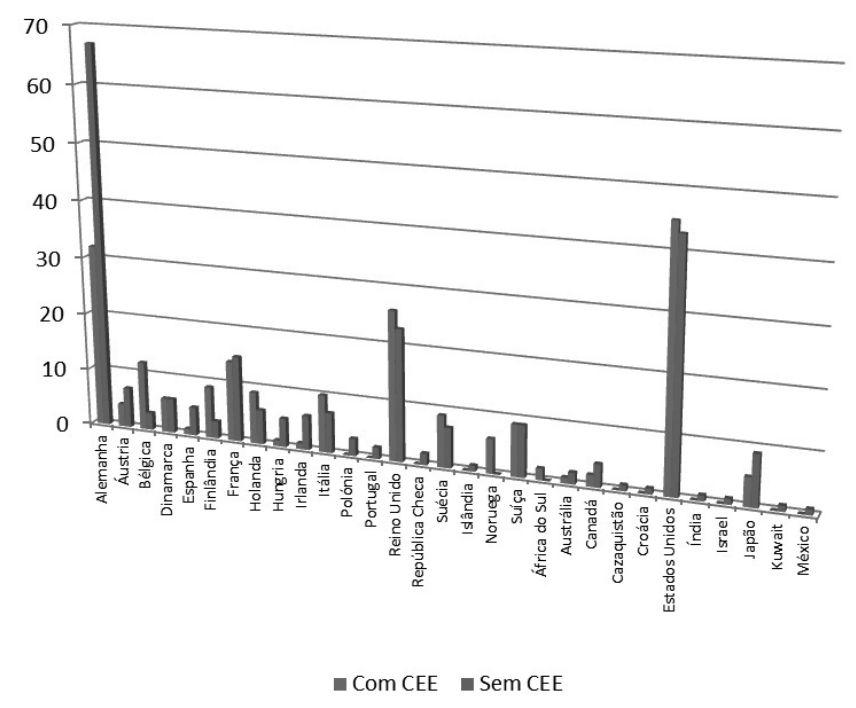

Fonte: European Works Councils Database 2011 
a África do Sul e os EUA (Resto do Mundo). Neste setor de atividade, o país que mais se destaca pela negativa, ou seja, aquele que apresenta a menor taxa de concretização da aplicação da Diretiva é a Alemanha (ver gráfico 3).

No setor metalúrgico o panorama não é substancialmente diferente. Também aqui são poucos os países sede de multinacionais onde o número das empresas com CEEs ultrapassa o número daquelas que, preenchendo os requisitos da Diretiva, ainda o não fizeram. Esses países são apenas sete: Áustria, Bélgica, Finlândia, França e Luxemburgo (UE - 27), Suécia (EFTA) e Singapura (Resto do Mundo). Mais uma vez a Alemanha regista, para o setor metalúrgico, uma taxa de concretização da aplicação da Diretiva bastante baixa, cerca de $26 \%$ (ver gráfico 4 ).

\section{GRÁfICO 4}

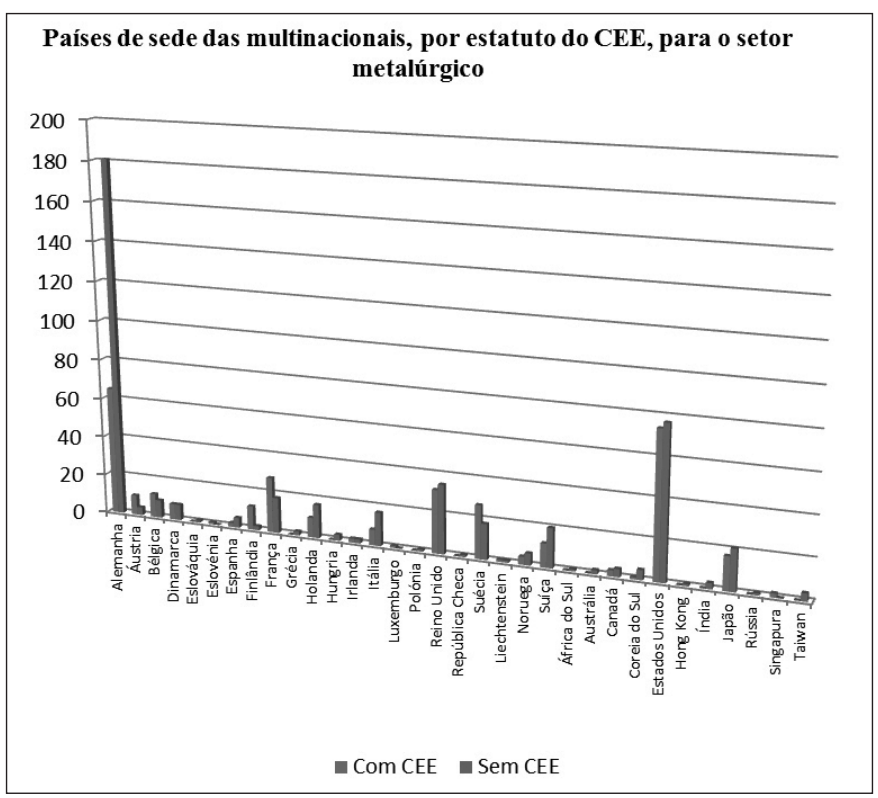

Fonte: European Works Councils Database 2011

Dos três setores em análise, o setor financeiro é aquele que apresenta globalmente a menor taxa de concretização da aplicação da Diretiva (só $39,7 \%$ das multinacionais abrangidas constituíram CEEs), no conjunto dos 
países considerados na base de dados. Os três países sede das multinacionais com menos CEEs criados são a Alemanha, os Estados Unidos e a Itália. No entanto, há já um razoável grupo de países cujas multinacionais do setor financeiro apresentam uma taxa de concretização da aplicação da Diretiva superior a 50\%. São eles: a Bélgica, a Dinamarca, a França, a Holanda, o Reino Unido e a Suécia (UE - 27), a Suíça (EFTA), e a Austrália (Resto do Mundo) (ver gráfico 5).

\section{GRÁfICO 5}

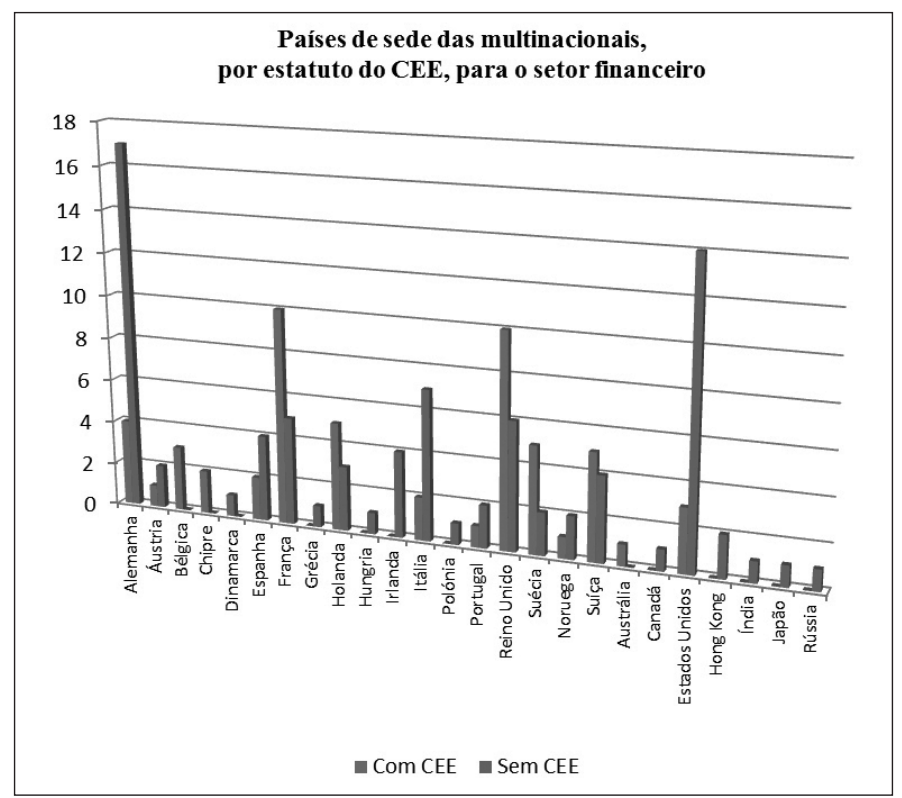

Fonte: European Works Councils Database 2011

\section{Países da sede das multinacionais com operações em Portugal, por setor de atividade}

A base de dados de 2011 dá conta de 360 multinacionais com operações em Portugal (nos três setores de atividade), 237 das quais já constituíram CEEs, ou seja, uma percentagem de 65,8\%. Daquelas, as multinacionais mais representadas são as que pertencem ao setor metalúrgico (200 ou 
$55,5 \%)$, seguidas das que se inscrevem no setor químico (122 ou 33,9\%) e de apenas 38 empresas pertencentes ao setor financeiro (10,6\%). Das multinacionais que operam em Portugal com CEEs formados, há a registar um total de 112 que elegeram representantes portugueses.

Quadro 5 - Multinacionais com operações em Portugal, por setor de atividade

\begin{tabular}{|c|c|c|c|c|}
\hline Setores & Químico & Metalúrgico & Financeiro & Total \\
\hline Multinacionais & 122 & 200 & 38 & 360 \\
\hline$\%$ & 33,9 & 55,5 & 10,6 & 100 \\
\hline
\end{tabular}

Fonte: European Works Councils Database 2011

\section{GRÁFICO 6}

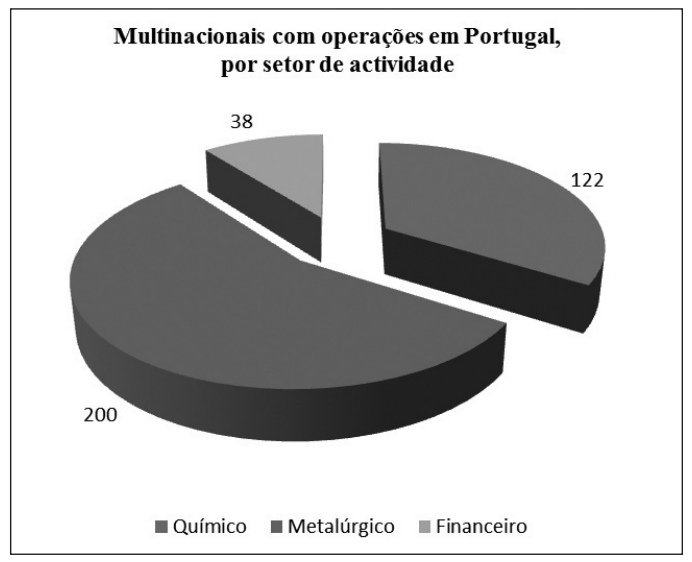

Fonte: European Works Councils Database 2011

Relativamente às multinacionais com operações em Portugal inscritas no âmbito da Diretiva (360 no total, como se referiu), segundo o país sede da multinacional, a Alemanha (72), a França (42) e o Reino Unido (31) destacam-se claramente em número de multinacionais no conjunto dos países da UE-27, a Suíça (13) no grupo dos países da EFTA, e no Resto do Mundo são os EUA (78) e o Japão (20) os dois países mais representados (ver quadro 6). 
QuAdro 6 - Países de sede das multinacionais com operações em Portugal, por setor de atividade

\begin{tabular}{|c|c|c|c|c|c|}
\hline & Países & Químico & Metalúrgico & Financeiro & Total \\
\hline \multirow{11}{*}{$\mathbf{U E}-\mathbf{2 7}$} & Alemanha & 21 & 47 & 4 & 72 \\
\hline & Áustria & 4 & 3 & 0 & 7 \\
\hline & Bélgica & 6 & 4 & 1 & 11 \\
\hline & Dinamarca & 4 & 6 & 0 & 10 \\
\hline & Espanha & 5 & 6 & 6 & 17 \\
\hline & Finlândia & 1 & 3 & 0 & 4 \\
\hline & França & 12 & 20 & 10 & 42 \\
\hline & Holanda & 3 & 6 & 4 & 13 \\
\hline & Itália & 5 & 4 & 0 & 9 \\
\hline & Portugal & 2 & 0 & 3 & 5 \\
\hline & Reino Unido & 15 & 12 & 4 & 31 \\
\hline \multirow{5}{*}{ EFTA } & Suécia & 2 & 13 & 1 & 16 \\
\hline & Islândia & 1 & 0 & 0 & 1 \\
\hline & Liechtenstein & 0 & 1 & 0 & 1 \\
\hline & Noruega & 0 & 1 & 0 & 1 \\
\hline & Suíça & 4 & 7 & 2 & 13 \\
\hline \multirow{8}{*}{$\begin{array}{c}\text { Resto do } \\
\text { Mundo }\end{array}$} & Austrália & 1 & 0 & 0 & 1 \\
\hline & Canadá & 1 & 2 & 0 & 3 \\
\hline & Coreia do Sul & 0 & 2 & 0 & 2 \\
\hline & Estados Unidos & 32 & 43 & 3 & 78 \\
\hline & Hong Kong & 0 & 1 & 0 & 1 \\
\hline & Japão & 3 & 17 & 0 & 20 \\
\hline & Singapura & 0 & 1 & 0 & 1 \\
\hline & Taiwan & 0 & 1 & 0 & 1 \\
\hline \multicolumn{2}{|c|}{ Total } & 122 & 200 & 38 & 360 \\
\hline
\end{tabular}

Fonte: European Works Councils Database 2011

Em relação às multinacionais presentes em Portugal e com CEEs ativos, nos três setores alvo deste estudo, a base de dados de 2011 dá conta de 237 empresas cuja sede se situa nos países que detêm, tendencialmente, o maior número de multinacionais abrangidas pela Diretiva: a Alemanha, 
a França e o Reino Unido, para a UE-27, a Suiça, para a EFTA, os EUA e o Japão, para o Resto do Mundo (quadro 7 e gráfico 7).

QUADRo 7 - Estatuto do CEE, nas multinacionais com operações em Portugal, por setor de atividade

\begin{tabular}{|c|c|c|c|c|}
\hline \multicolumn{1}{|c|}{ Estatuto do CEE } & Químico & Metalúrgico & Financeiro & Total \\
\hline Com CEE & 83 & 130 & 24 & 237 \\
\hline Sem CEE & 36 & 69 & 13 & 118 \\
\hline Em negociações & 3 & 1 & 1 & 5 \\
\hline Total & 122 & 200 & 38 & 360 \\
\hline
\end{tabular}

Fonte: European Works Councils Database 2011

\section{GRÁFICO 7}

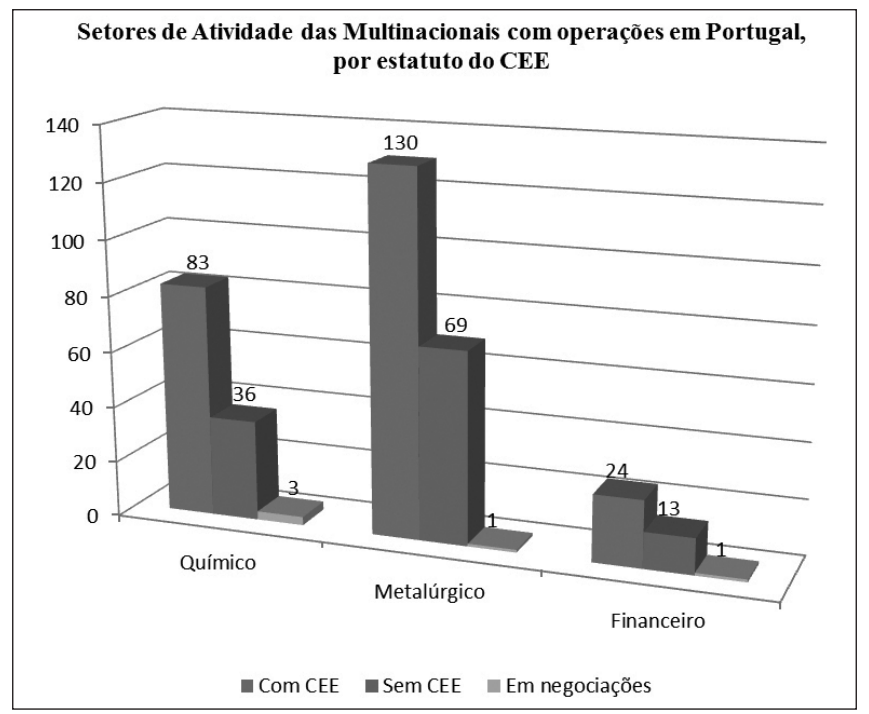

Fonte: European Works Councils Database 2011

Se olharmos para estes dados mas agora segundo o setor de atividade verificamos que no setor químico, em relação aos países que são sede 
de multinacionais com CEE instituídos e a operar em Portugal, existe em quase todos uma correlação positiva em relação ao número de multinacionais com e sem CEEs, ou seja, a percentagem de multinacionais com CEEs é quase sempre superior à percentagem de multinacionais sem CEEs, com cinco exceções: Dinamarca, Espanha, Finlândia, Portugal e Japão. Relativamente ao setor metalúrgico, com a exceção da Alemanha, da Espanha e de Taiwan, a correlação continua a ser positiva para o conjunto considerado de países. No setor financeiro, que dos três setores é o que apresenta o menor número de multinacionais com CEE a operar em Portugal, o número de multinacionais com CEEs supera sempre o número daquelas que não têm ainda CEE, com a exceção da Espanha, de Portugal, da Suécia e dos EUA.

GRÁfICO 8

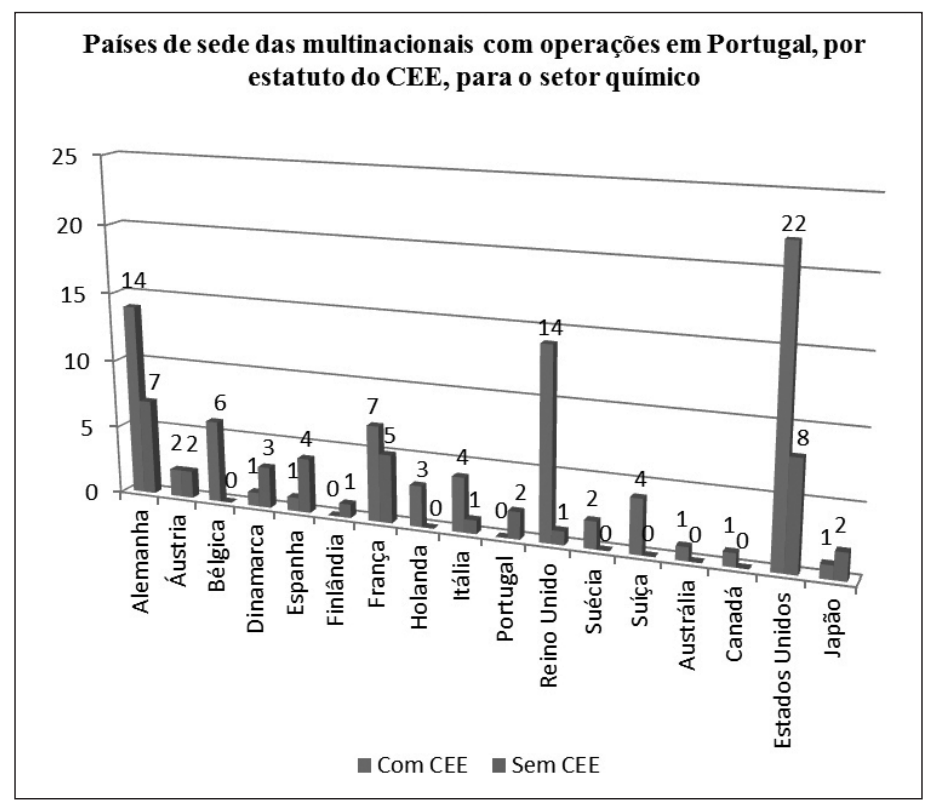

Fonte: European Works Councils Database 2011 


\section{GRÁFICO 9}

Países de sede das multinacionais com operações em Portugal, por estatuto do CEE, setor metalúrgico

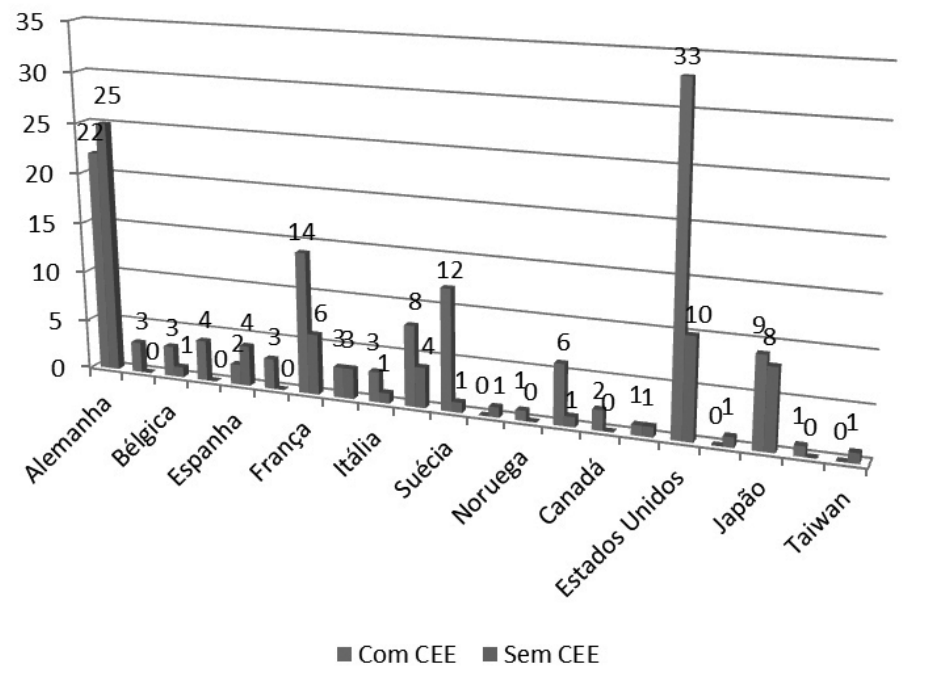

GRÁFICO 10

Países de sede das multinacionais com operações em Portugal, por estatuto do CEE, para o setor financeiro

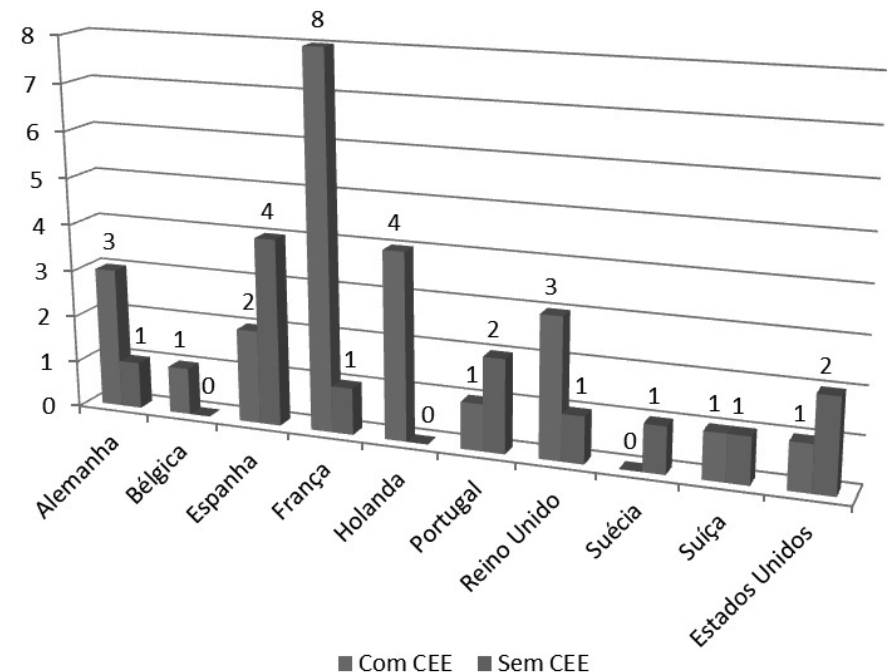

Fonte: European Works Councils Database 2011 
Na base de dados de 2011, Portugal aparece, como já se disse, com 5 empresas multinacionais (nos três setores de atividade considerados) que reúnem as condições necessárias para a criação de CEEs, duas pertencentes ao setor químico e três ao setor financeiro. Das cinco, apenas o Grupo Banco Espírito Santo (Grupo BES) começou por instituir, em julho de 2003, um procedimento de informação e consulta dos trabalhadores, o qual, em março de 2005, se converteu em CEE.

A breve síntese quantitativa do processo de constituição de CEEs nos três setores de atividade mais representativos revela que muito há a fazer para aumentar a taxa de aplicação da Diretiva uma vez que esta ainda não conseguiu atingir os 50\% em nenhum dos setores (globalmente é de $42 \%$ ). Portugal, apesar de possuir poucas empresas em condições de constituir CEEs (5 nos três setores), não foge à regra e enquadra-se neste "movimento" de alguma resistência aos CEEs. Uma parte das motivações para que esse delay na constituição de CEEs foi abordado nos capítulos anteriores e recobre uma diversidade mitigada de fatores. Um tratamento mais detalhado dos fatores que dificultam a constituição de CEEs nas (poucas) empresas com sede em Portugal pode encontrar-se em Costa e Araújo (2009: 45-52). Muito resumidamente, esses fatores podem agrupar-se em três conjuntos de obstáculos:

i) Por um lado, os obstáculos relacionados com o contexto socioeconómico. $\mathrm{Na}$ verdade, um tecido produtivo caracterizado sobretudo por pequenas e médias empresas (portanto pouco propício a lidar de forma mais regular com a atuação das multinacionais), destaca-se não só o peso das preocupações nacionais e locais, como o peso dos processos de privatização empresarial;

ii) Por outro lado, os obstáculos associados às características do sistema de relações laborais português e às relações entre os principais atores das organizações de representação dos trabalhadores (ORTs) nacionais (CTs e sindicatos): o direito à informação e consulta não é considerado como uma mais-valia, na medida em que já se encontra previsto na legislação que regula quer as Comissões de Trabalhadores (art. 54. ${ }^{\circ},{ }^{\circ}{ }^{5}$, al. a), da Constituição da República 
Portuguesa, CRP), quer a liberdade sindical (art. 55. ${ }^{\circ}$, n. $^{\circ} 6$, da CRP); a proximidade geográfica à "casa-mãe" da empresa facilita o acesso à informação e os próprios estatutos das estruturas nacionais de representação dos trabalhadores consagram o direito à informação, aspetos que relativizam o "apelo" aos CEEs; os conflitos entre as principais organizações locais de representação dos trabalhadores; a indisponibilidade para acumular funções para além daquelas que os representantes dos trabalhadores já desempenham; a rotatividade nas lideranças locais das organizações representativas de trabalhadores, que funciona como um pretexto para adiar sistematicamente os CEEs da agenda de intervenção mais imediata; a rotatividade nas lideranças estrangeiras das organizações representativas dos trabalhadores, que impede um trabalho continuado com interlocutores fixos; o défice de contactos entre representantes dos órgãos de representação dos trabalhadores das sucursais nacionais e estrangeiras; o desconhecimento das formas de organizações de trabalhadores e dos representantes dos trabalhadores nas sucursais estrangeiras; a inexistência de quaisquer espaços de representação sindical/laboral na empresa; e os conflitos entre as organizações de representação dos trabalhadores e as entidades empregadoras.

iii) Por fim, os obstáculos relacionados com a avaliação subjetiva que os representantes dos trabalhadores portugueses dessas multinacionais com sede em Portugal fazem da importância dos CEEs e da sua funcionalidade. E aqui destaca-se, por exemplo: a dificuldade em apreender o sentido prático (eficácia) associado aos CEEs; a ideia de que se trata de um processo moroso (que implica negociações com distintas, e muitas vezes distantes, organizações de trabalhadores, e entre estas e a entidade empregadora); o escasso número de ações de formação sobre a problemática dos CEEs (quer promovido pelas administrações das multinacionais, quer pelas organizações representativas dos trabalhadores); e a (quase) inexistência de experiências nacionais em CEEs, que possam constituir uma referência a ter em conta e que concorrem também para alimentar um défice de informação sobre os CEEs. 
(Página deixada propositadamente em branco) 


\section{CA P Í T U L O 4}

\section{ACORdOS DE CONSELHOS DE EMPRESA EUROPEUS ENVOLVENDO REPRESENTANTES PORTUGUESES EM MULTINACIONAIS DOS SETORES METALÚRGICO, QU Í M I C O E F I NANCEIRO}

Neste capítulo procede-se a uma análise detalhada do conteúdo dos acordos dos CEEs envolvendo representantes de trabalhadores portugueses, atribuindo especial atenção: à natureza dos acordos, à sua composição, objetivos e competências; ao processo de seleção dos representantes dos trabalhadores, e ao modo como a organização das reuniões se encontra prevista nos acordos.

Como vimos no capítulo anterior, a base de dados organizada pelo Instituto Sindical Europeu contabiliza para o ano de 2011 um total de 237 multinacionais com operações em Portugal e com CEEs ativos. Destas, 112 têm pelo menos um representante português no CEE (ou seja, 47,2\%), o que significa que 125 dessas multinacionais não elegeram qualquer representante nacional, apesar de terem registo de atividade no nosso país e de terem CEE constituído (ver quadro 8 e Gráfico 11). Tal facto vai, pois, igualmente ao encontro de outra das dificuldades associadas ao funcionamento dos CEEs já reportada noutros estudos (Costa, 1996; 2004a; 2004b; Costa e Araújo, 2009). 
QUADRO 8 - Multinacionais, por presença em Portugal, setores, CEE e existência de representante português

\begin{tabular}{|l|c|c|c|c|}
\cline { 2 - 5 } \multicolumn{1}{c|}{} & Químico & Metalúrgico & Financeiro & Total \\
\hline Multinacionais & 452 & 816 & 141 & 1409 \\
\hline Multinacionais em Portugal & 122 & 200 & 38 & 360 \\
\hline Com CEE & 83 & 130 & 24 & 237 \\
\hline Com representante Português & 39 & 58 & 15 & 112 \\
\hline
\end{tabular}

Fonte: European Works Councils Database 2011

GRÁFICO 11

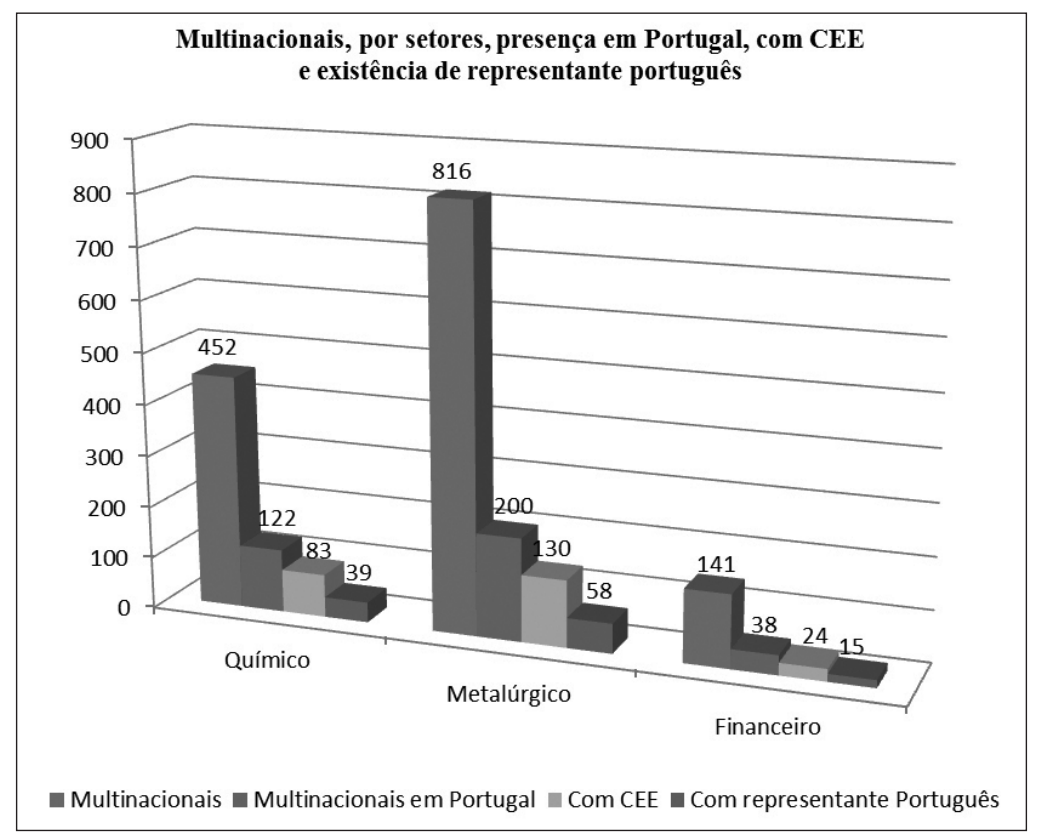

Fonte: European Works Councils Database 2011

\section{Acordos em vigor e data da assinatura}

Nas 112 multinacionais registadas em Portugal com pelo menos um representante dos trabalhadores português é possível constatar a existência de 111 acordos em vigor, cujos CEEs pertencem a multinacionais com 
sede em quatro países principais: são eles, por ordem de importância, os EUA (27 multinacionais ou 24,3\%), a Alemanha (19 empresas ou 17,1\%), a França (19 multinacionais ou 17,1\%) e a Suíça (10 multinacionais ou 9\%). Não deixa de ser curioso notar que é um país fora da Europa (ou, mais precisamente, fora do EEE) aquele que regista mais multinacionais com operações em Portugal e com, pelo menos, um representante português eleito para um órgão de representação de cariz europeu (quadro 9 e gráfico 12).

QuADro 9 - Acordos em vigor, por país de sede das multinacionais

\begin{tabular}{|c|c|c|c|c|}
\hline \multicolumn{3}{|c|}{ Países da sede } & $\mathbf{N}$ & $\%$ \\
\hline \multirow{12}{*}{ Países do EEE } & \multirow{11}{*}{ UE-15 } & Alemanha & 19 & $17,12 \%$ \\
\hline & & Áustria & 1 & $0,90 \%$ \\
\hline & & Bélgica & 3 & $2,70 \%$ \\
\hline & & Dinamarca & 2 & $1,80 \%$ \\
\hline & & Espanha & 4 & $3,60 \%$ \\
\hline & & França & 19 & $17,12 \%$ \\
\hline & & Holanda & 4 & $3,60 \%$ \\
\hline & & Itália & 4 & $3,60 \%$ \\
\hline & & Portugal & 1 & $0,90 \%$ \\
\hline & & Reino-Unido & 8 & $7,21 \%$ \\
\hline & & Suécia & 3 & $2,70 \%$ \\
\hline & EFTA & Suíça & 10 & $9,01 \%$ \\
\hline \multirow{5}{*}{\multicolumn{2}{|c|}{ Países fora do EEE }} & Austrália & 1 & $0,90 \%$ \\
\hline & & Coreia do Sul & 1 & $0,90 \%$ \\
\hline & & EUA & 27 & $24,32 \%$ \\
\hline & & Japão & 3 & $2,70 \%$ \\
\hline & & Singapura & 1 & $0,90 \%$ \\
\hline \multicolumn{3}{|c|}{ Total } & 111 & $100,00 \%$ \\
\hline
\end{tabular}


GRÁFICO 12

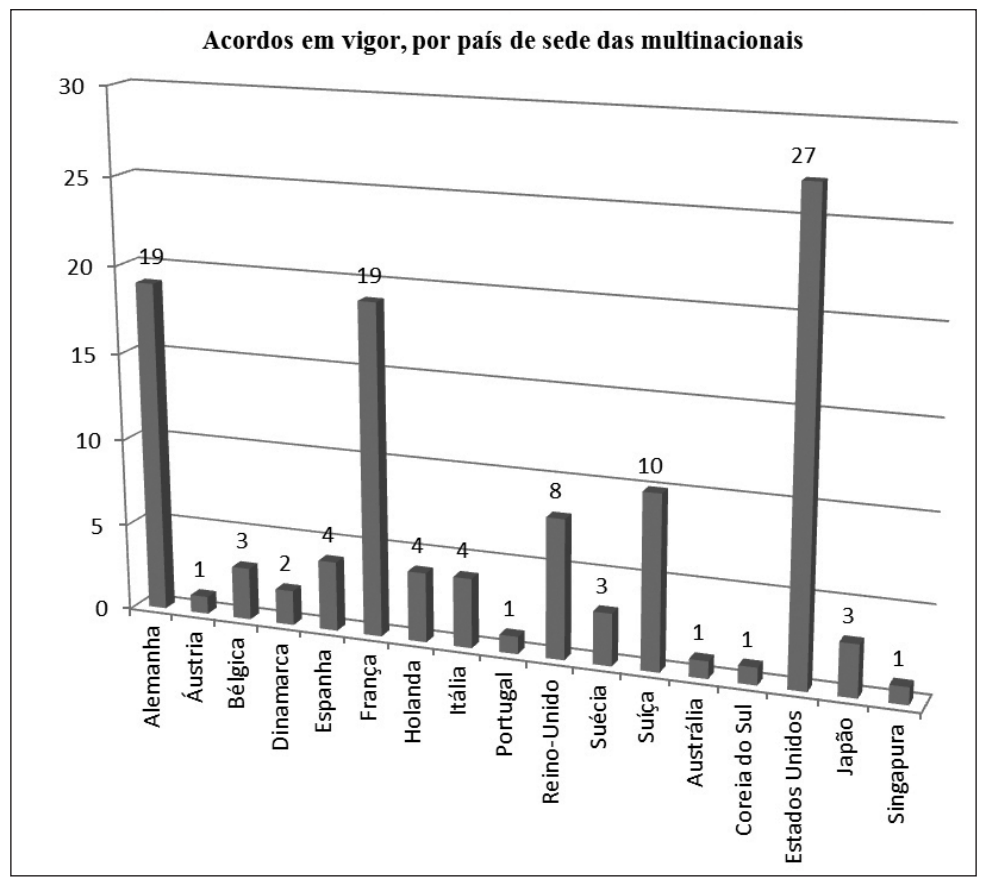

Se olharmos para a evolução recente do número de acordos que contam com a eleição de, pelo menos, um representante português verificamos que existe um aumento muito ligeiro entre 2006 e 2010: o número de acordos passou de 106, em 2006, para 111, em 2010. Este ténue aumento verificou-se em multinacionais pertencentes aos setores químico e metalúrgico. As empresas ligadas às atividades financeiras a operar em Portugal mantiveram o mesmo número de acordos (15) naquele período (quadro 10 e gráfico 13).

Um dado interessante prende-se com a data de assinatura dos 111 acordos vigentes registados em empresas com operações em Portugal e com CEEs constituídos. A data da primeira assinatura de $32,4 \%$ destes 111 acordos foi o ano de 1996 (o ano limite da transposição para o direito nacional da Diretiva 94/45/CE). Também os anos de 1998, 2000 e 2001 tiveram alguma expressão em termos de acordos assinados pela primeira vez $(12,10$ e 10, respetivamente), diminuindo desde então o ritmo de assinatura de novos acordos registado pela base de dados. 
Destes 111 acordos, muitos foram, entretanto, sujeitos a reformulações e revisões, o que significou que a última assinatura válida conhecida foi alterada. Mais uma vez, o ano de 1996 foi favorável à (re)assinatura de acordos (19) assim como o ano de 2003 (12), de 2000 (11) e 2001 (11). De realçar ainda que cerca de $30 \%$ dos 111 acordos em vigor registados em empresas com operações em Portugal, com CEE e com pelo menos um representante português eleito, assinou o acordo do CEE respetivo no período entre 2004 e 2009 (ver quadro 11 e gráfico 14).

QUADRO 10 - Acordos em vigor, por setor de atividade*

\begin{tabular}{|l|c|c|c|}
\hline \multirow{2}{*}{\multicolumn{1}{|c|}{ Setores de atividade }} & \multicolumn{2}{c|}{ Número de Acordos em vigor } & \multirow{2}{*}{ Variação } \\
\cline { 2 - 4 } & $\mathbf{2 0 0 6}$ & $\mathbf{2 0 1 0}$ & \\
\hline Químico & 36 & 39 & 3 \\
\hline Metalúrgico & 55 & 58 & 0 \\
\hline Atividades financeiras & 15 & 15 & 2 \\
\hline $\begin{array}{l}\text { * Os valores encontram-se ligeiramente empolados devido às multinacionais que operam em } \\
\text { mais do que um setor }\end{array}$ & \\
\hline
\end{tabular}

Fonte: European Works Councils Database 2011

GRÁfICO 13

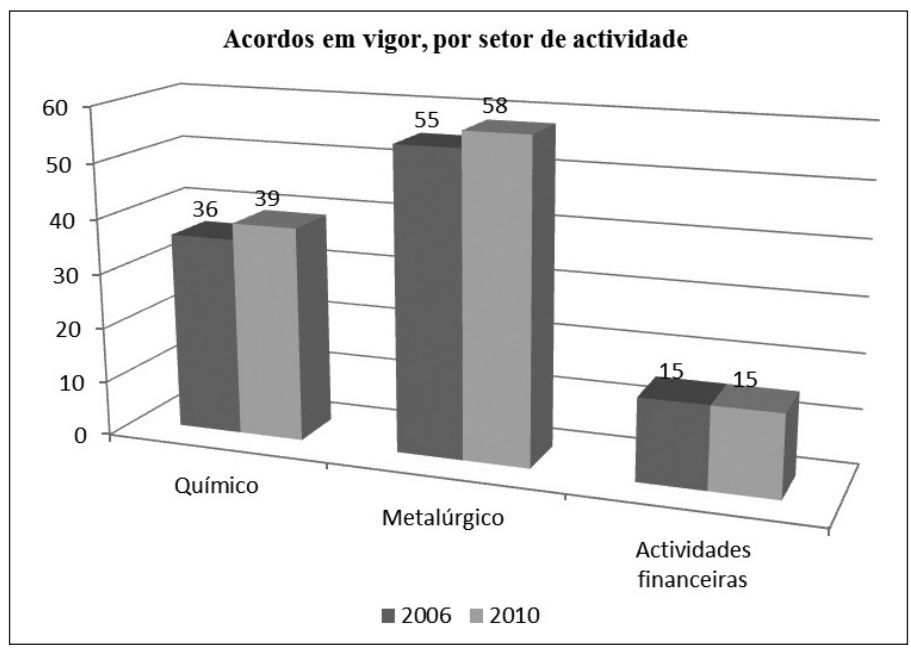

Fonte: European Works Councils Database 2011 
QUADRO 11 - Acordos em Vigor

\begin{tabular}{|c|c|c|}
\hline Ano & Por ano da primeira assinatura & Por ano da última assinatura \\
\hline 1992 & 3 & 0 \\
\hline 1993 & 3 & 1 \\
\hline 1994 & 1 & 1 \\
\hline 1995 & 7 & 3 \\
\hline 1996 & 36 & 19 \\
\hline 1997 & 4 & 3 \\
\hline 1998 & 12 & 7 \\
\hline 1999 & 7 & 2 \\
\hline 2000 & 10 & 11 \\
\hline 2001 & 10 & 11 \\
\hline 2002 & 4 & 8 \\
\hline 2003 & 6 & 12 \\
\hline 2004 & 3 & 10 \\
\hline 2005 & 0 & 6 \\
\hline 2006 & 1 & 2 \\
\hline 2007 & 0 & 6 \\
\hline 2008 & 4 & 6 \\
\hline 2009 & 0 & 3 \\
\hline
\end{tabular}

Fonte: European Works Councils Database 2011

\section{Natureza dos acordos}

Seguidamente olha-se mais atentamente para o conteúdo dos acordos dos CEEs envolvendo representantes portugueses nos setores em análise.

\subsection{Tipo de acordo}

Recorde-se que a Diretiva 94/45/CE estipulara duas situações relativamente aos acordos: primeiro, o reconhecimento de acordos voluntários 
que fossem aplicáveis a todos os trabalhadores e que previssem a informação e consulta transnacionais dos trabalhadores (artigo 13..$^{\circ}$ ); segundo, que terminadas as negociações entre as partes (direção central e representantes dos trabalhadores ou Grupo Especial de Negociação/GEN), a celebração de um acordo para a definição do mecanismo transnacional de informação e consulta a adotar (artigo $6 .^{\circ}$ ), traduzido num CEE ou num Procedimento de Informação e Consulta dos trabalhadores (PIC).

GRÁFICO 14

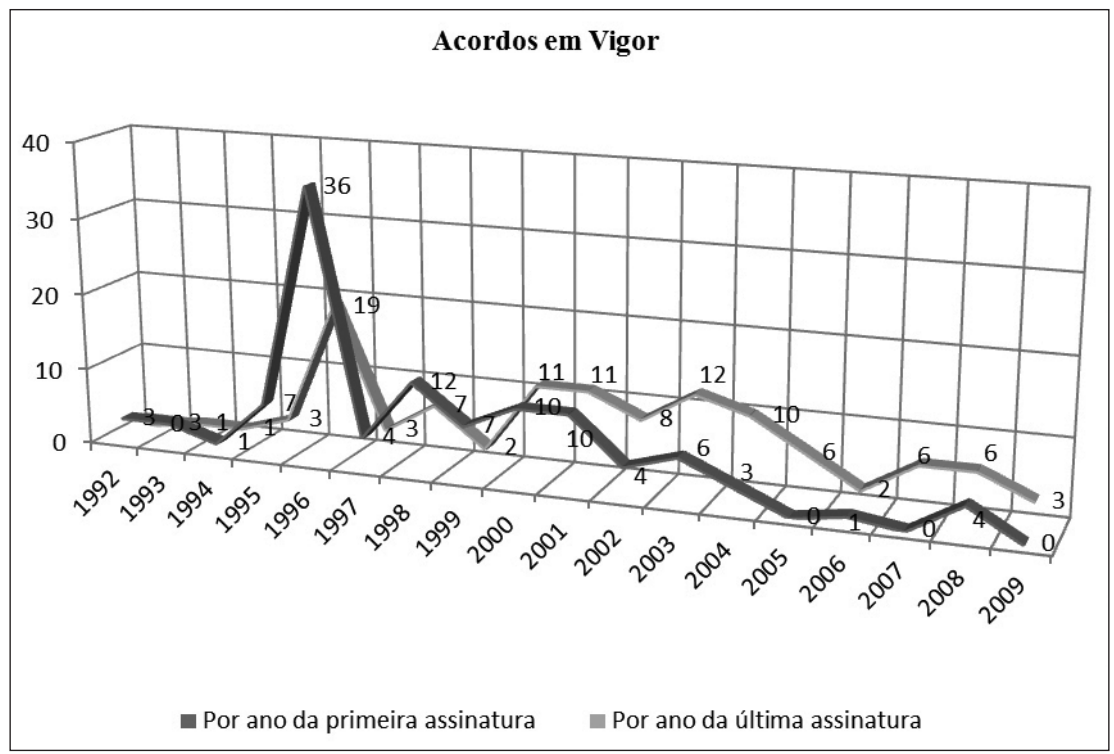

Fonte: European Works Councils Database 2011

Assim, nos termos do artigo $13 .^{\circ}$ da Diretiva 94/45/CE, encontrava-se previsto o reconhecimento de acordos voluntários para os quais, findo o período de duração, as partes podiam optar pela sua prorrogação ou dar cumprimento ao disposto na Diretiva (artigo $13 .^{\circ}, \mathrm{n} .{ }^{\circ} 2$ ).

Comparativamente ao artigo $13 .^{\circ}$, que confere às partes alguma flexibilidade no ajustamento do procedimento de informação e consulta às particularidades da multinacional (Leite et al., 1996: 83), o artigo 6. ${ }^{\circ}$ (cujos termos se mantêm na Diretiva 2009/38/CE) revelou-se mais rigo- 
roso no que concerne à definição do conteúdo dos acordos. De facto, se baseados no artigo $6 .^{\circ}$, os acordos de CEEs devem possuir um conjunto de elementos obrigatórios a serem negociados entre a direção central da empresa em causa e o GEN, como sejam: as empresas do grupo de dimensão comunitária ou os estabelecimentos de empresas de dimensão comunitária abrangidos pelo acordo; a composição do CEE, bem como o número de membros, a distribuição dos lugares e a duração do mandato (as partes possuem aqui discricionariedade total para escolher os membros e respetivo número; definir se o CEE é composto apenas por trabalhadores da multinacional ou incluir outros representantes como sejam peritos ou representantes de organizações sindicais); as atribuições e o procedimento de informação e consulta do CEE; o local, a frequência e a duração das reuniões do CEE; os recursos financeiros e materiais a afetar ao CEE; e a duração do acordo e o seu processo de renegociação.

A análise dos 111 acordos em vigor nas multinacionais com operações em Portugal e com pelo menos um representante português eleito revela que a maioria foi celebrada com base no artigo $13 .^{\circ}$ da Diretiva. Contudo, o número de acordos celebrados com base no artigo $6 .^{\circ}$ fica muito próximo, 59 e 52, respetivamente. De realçar o facto de, dos 59 acordos baseados no artigo $13 .^{\circ}, 29$ terem sido reformulados no seguimento de reestruturações (fusões, dissoluções ou aquisições), o que significa, por um lado, que se trata de CEEs com uma já extensa longevidade e, por outro, que, aquando das revisões e reformulações, essa experiência poderá ter originado alterações significativas no conteúdo dos acordos (quadro 12 e gráfico 15).

QUADro 12 - Tipo de Acordo

\begin{tabular}{|c|c|c|c|c|c|}
\cline { 2 - 6 } \multicolumn{1}{c|}{} & $\begin{array}{c}\text { Artigo 13. } \\
\text { (acordos } \\
\text { voluntários) }\end{array}$ & $\begin{array}{c}\text { Artigo 13. }{ }^{\circ} \text { (acordos } \\
\text { reformulados } \\
\text { ou pós-fusão) }\end{array}$ & $\begin{array}{c}\text { Artigo 6. } \\
\text { (acordos } \\
\text { celebrados) }\end{array}$ & $\begin{array}{c}\text { Artigo 6. }{ }^{\circ} \text { (acordos } \\
\text { reformulados } \\
\text { ou pós-fusão) }\end{array}$ & Total \\
\hline $\mathbf{N}$ & 30 & 29 & 39 & 13 & 111 \\
\hline$\%$ & $27,0 \%$ & $26,1 \%$ & $35,1 \%$ & $11,7 \%$ & $100,0 \%$ \\
\hline
\end{tabular}

Fonte: European Works Councils Database 2011 


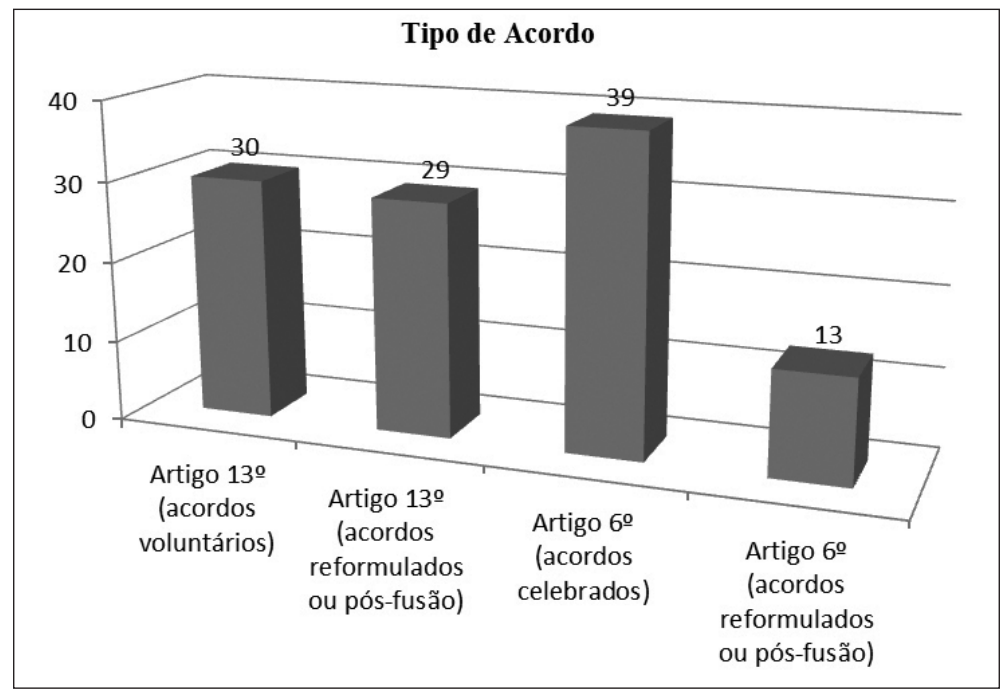

Fonte: European Works Councils Database 2011

Se atendermos agora ao cruzamento do tipo de acordo com o setor de atividade verificamos que existe, nos três setores em análise, um equilíbrio notório entre o número de acordos assinados ao abrigo do artigo $13 .^{\circ}$ e $6 .^{\circ}$, com a exceção do setor químico, onde constatamos uma preponderância de acordos celebrados ao abrigo do artigo $13 .^{\circ}$. Dos 39 acordos assinados por multinacionais pertencentes ao setor químico, 24 foram assinados ao abrigo do artigo $13 .^{\circ}$ e apenas 15 ao abrigo do artigo 6. ${ }^{\circ}$. Nos dois restantes setores há quase que uma repartição equitativa entre os acordos assinados segundo o artigo $13 .^{\circ}$ e $6 .^{\circ}$ (ver quadro $13 \mathrm{e}$ gráfico 16). Uma referência ainda ao número de acordos (artigos $13 .^{\circ} \mathrm{e}$ $\left.6 .^{\circ}\right)$ reformulados na sequência de reestruturações e que mostra ter um peso diferente consoante o setor em causa: é maior no setor financeiro e metalúrgico e menos expressivo no setor químico. No setor financeiro, dos 15 acordos contabilizados, 8 foram reformulados na sequência de reestruturações, e no setor metalúrgico, dos 58 registados na base de dados, 25 também foram reformulados (43,1\%). No setor químico, apenas $25,6 \%$ dos acordos registados foram o resultado de reformulações. 
QUADRO 13 - Tipo de acordo por setor de atividade

\begin{tabular}{|l|c|c|c|c|c|c|}
\cline { 2 - 7 } \multicolumn{1}{c|}{} & \multicolumn{2}{c|}{ Artigo 13. } & \multicolumn{3}{c|}{ Artigo 6. } \\
\hline $\begin{array}{c}\text { Setores de } \\
\text { atividade }\end{array}$ & $\begin{array}{c}\text { Acordos } \\
\text { voluntários }\end{array}$ & $\begin{array}{c}\text { Acordos } \\
\text { reformulados } \\
\text { ou pós-fusão }\end{array}$ & Total & $\begin{array}{c}\text { Acordos } \\
\text { celebrados }\end{array}$ & $\begin{array}{c}\text { Acordos } \\
\text { reformulados ou } \\
\text { pós-fusão }\end{array}$ & Total \\
\hline Químico & 15 & 9 & 24 & 14 & 1 & 15 \\
\hline Metalúrgico & 13 & 15 & 28 & 20 & 10 & 30 \\
\hline $\begin{array}{l}\text { Atividades } \\
\text { financeiras }\end{array}$ & 2 & 5 & 7 & 5 & 3 & 8 \\
\hline
\end{tabular}

Fonte: European Works Councils Database 2011

GRÁFICO 16

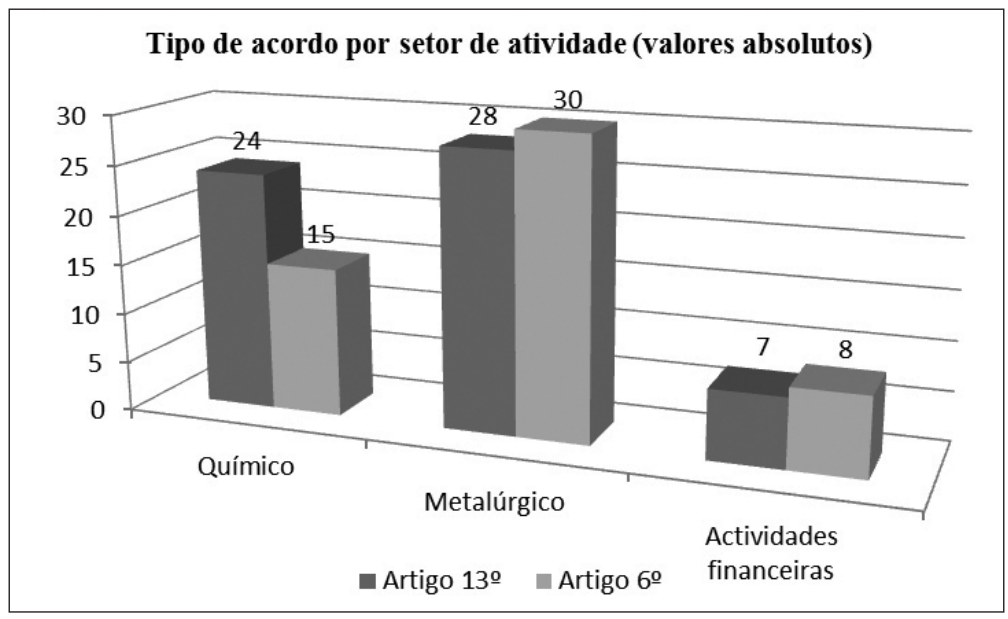

Fonte: European Works Councils Database 2011

\subsection{Signatários dos acordos: representantes dos trabalhadores}

A direção central da empresa multinacional, através dos seus representantes - que podem ser, o presidente do conselho de administração, o diretor dos recursos humanos, ou outros - aparece invariavelmente referida nos acordos como signatária por parte da entidade empregadora. Relativamente aos representantes dos trabalhadores, os acordos em análise (111) foram maioritariamente assinados por representantes dos trabalhadores não especificados (em 29,7\% dos casos) e pelos membros 
do Grupo Especial de Negociações (GEN - 28,8\% dos acordos) (ver quadro 14 e gráfico 17). Note-se, porém, que as designações dos signatários que constam dos acordos nem sempre permitem um esclarecimento cabal das organizações de trabalhadores em causa, ainda que seja legítimo considerar que as organizações sindicais (OS) desempenham um papel ativo nas negociações dos acordos, nomeadamente como co-assinantes. Estamos por isso em crer que, sob as designações Conselho de Empresa Europeu (CEE), Grupo Especial de Negociação (GEN), comissões de trabalhadores (CTs) ou representantes de trabalhadores (RTs), uma parte muito significativa são representantes de organizações sindicais.

QUADRO 14 - Signatários dos acordos por parte dos trabalhadores

\begin{tabular}{|c|c|c|c|c|c|c|c|c|}
\cline { 2 - 8 } \multicolumn{1}{c|}{} & CEE & GEN & RTs & RTs + OS & OS & CTs & Não referido & Total \\
\hline $\mathbf{N}$ & 19 & 32 & 33 & 4 & 10 & 8 & 5 & 111 \\
\hline$\%$ & $17,1 \%$ & $28,8 \%$ & $29,7 \%$ & $3,6 \%$ & $9,0 \%$ & $7,2 \%$ & $4,5 \%$ & $100,0 \%$ \\
\hline
\end{tabular}

Fonte: European Works Councils Database 2011

GRÁFICO 17

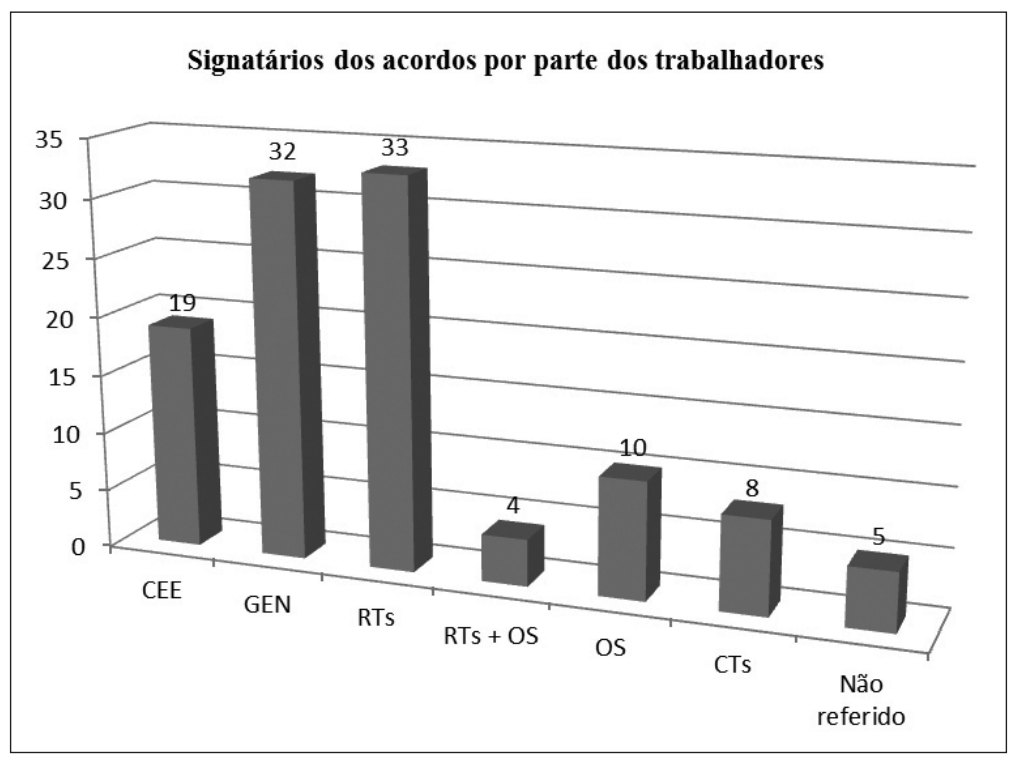

Fonte: European Works Councils Database 2011 
Alguns trabalhos já realizados confirmam esta ideia da participação ativa dos sindicatos nos acordos. Por exemplo, tendo por base 386 acordos celebrados voluntariamente nos termos do artigo $13 .^{\circ}$ da Diretiva 94/45/CE, Lecher, Marginson e Buschak verificaram que os sindicatos participaram, quer como co-assinantes, quer desempenhando um papel ativo nas negociações dos acordos em cerca de $75 \%$ das situações (Lecher, 1999: 299; Marginson, 1999: 266; Buschak, 1999: 388; Buschak, 2000: 169). Recorde-se, no entanto, que, apesar da forte presença sindical nas negociações dos acordos, a Diretiva aplica-se a trabalhadores de multinacionais seja qual for a forma pela qual estes se encontrem representados.

As organizações sindicais, nacionais ou internacionais, que figuram como signatárias dos acordos aparecem maioritariamente no caso dos acordos celebrados ao abrigo do artigo $13 .^{\circ}$. O mesmo acontece relativamente aos acordos assinados por representantes dos trabalhadores não especificados. Os acordos assinados no âmbito do artigo 6. ${ }^{\circ}$, por sua vez, tal como previsto na Diretiva 94/45/CE, são negociados e firmados entre o GEN e a direção central (artigo 6. ${ }^{\circ}$, n. $^{\circ} 1$ ).

\subsection{Legislação nacional aplicável}

Em relação à legislação nacional a aplicar no funcionamento dos CEEs e em caso de litígio, em 55\% dos 111 acordos analisados esta refere-se à legislação do país de sede da multinacional (ver Quadro 15).

QUADRO 15 - Legislação aplicável

\begin{tabular}{|c|c|c|c|c|}
\cline { 2 - 5 } \multicolumn{1}{c|}{} & Igual à do país de origem & Diferente do país de origem & Não referido & Total \\
\hline $\mathbf{N}$ & 62 & 44 & 5 & 111 \\
\hline$\%$ & $55 \%$ & $41 \%$ & $5 \%$ & $100 \%$ \\
\hline
\end{tabular}


Comparando a legislação aplicável das multinacionais cuja sede se localiza no e fora do EEE, as duas situações mais comuns são as seguintes: no caso da sede da multinacional se encontrar num país fora do EEE (EUA, Japão, Austrália, etc.) aplica-se a legislação de um dos países do EEE, enquanto que no caso da sede da multinacional se encontrar num país do EEE tende-se a aplicar a legislação do país da sede (ver quadros 16 e 17 e gráfico 18). Dos países pertencentes ao EEE, a Suíça é o único país (dos que estão em análise como países sede de multinacionais com CEE constituídos e com pelo menos um representante português eleito) que apresenta a situação de na quase totalidade dos seus acordos vigorar legislação diferente do país de origem. Os restantes países do EEE aplicam quase integralmente a legislação igual à do país de origem da multinacional em causa. Já nos países fora do EEE a situação é a contrária, ou seja, nenhum dos países estudados faz valer nos seus acordos de CEEs a legislação interna.

QUADRO 16 - Legislação nacional aplicável

\begin{tabular}{|c|c|c|c|c|c|}
\cline { 2 - 6 } \multicolumn{1}{c|}{} & \multicolumn{2}{|c|}{ Igual à do país de origem } & \multicolumn{2}{l|}{ Diferente do país de origem } & Não referido \\
\cline { 2 - 6 } & EEE & Fora do EEE & EEE & Fora do EEE & \\
\hline $\mathrm{N}$ & 62 & 0 & 13 & 31 & 5 \\
\hline
\end{tabular}

Fonte: European Works Councils Database 2011

\subsection{Alcance geográfico}

Os acordos não definem uniformemente o alcance geográfico, destacando-se nos 111 acordos analisados, ainda assim, as situações em que os acordos abrangem: 1) sucursais da multinacional na UE e no EEE (44 acordos); 2) sucursais localizadas na UE (20 acordos); 3) sucursais sob o controlo da multinacional (18 acordos) (ver quadro 18 e gráfico 19). 
QUADRO 17 - Legislação aplicável, igual ou diferente à do país de origem, por país, no e fora do EEE

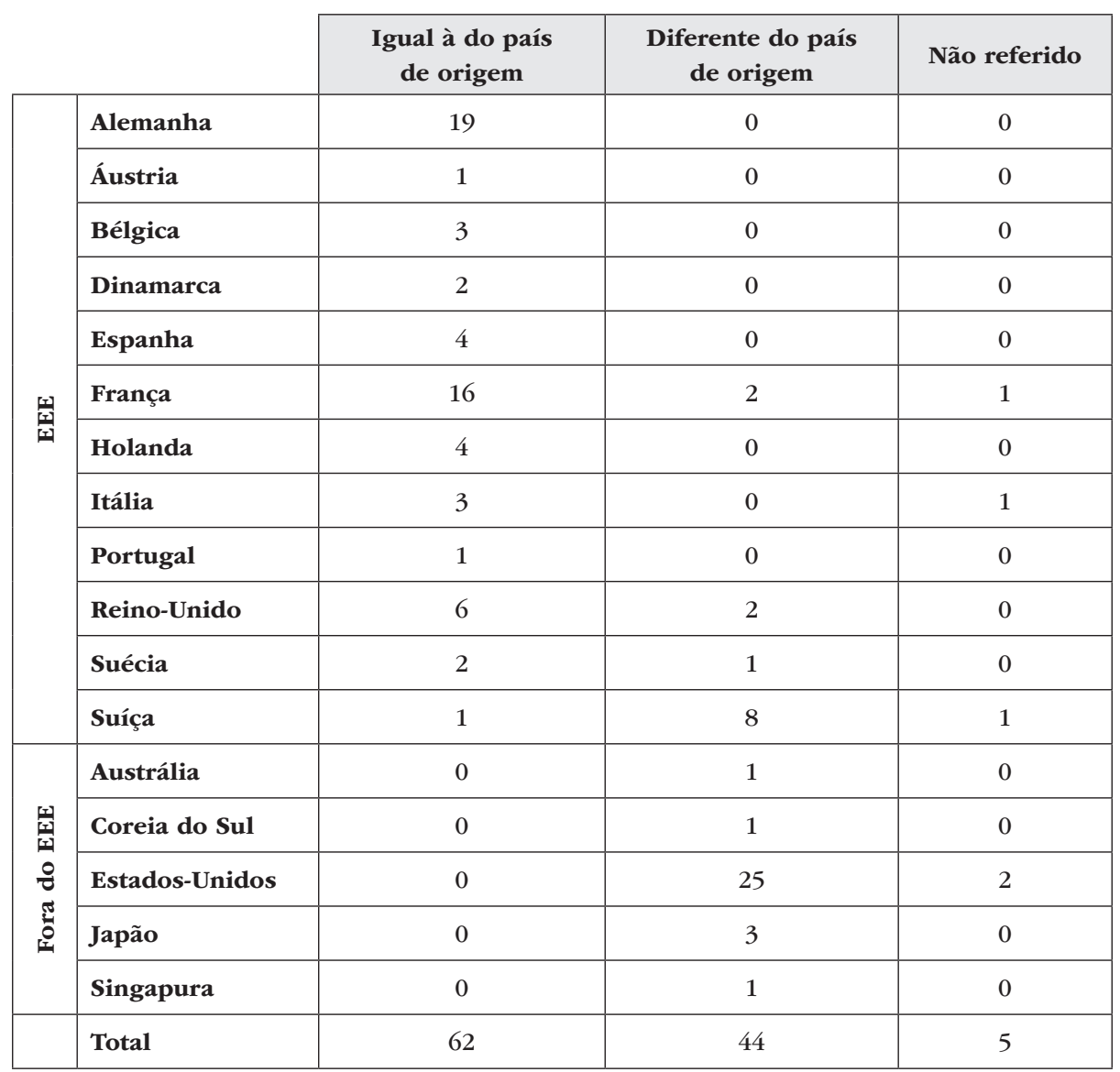

Fonte: European Works Councils Database 2011

QUADRO 18 - Alcance geográfico dos acordos (sucursais abrangidas)

\begin{tabular}{|c|c|c|c|c|c|c|c|c|}
\cline { 2 - 8 } \multicolumn{1}{c|}{} & UE & $\begin{array}{c}\text { UE }+ \\
\text { EEE }\end{array}$ & $\begin{array}{c}\text { Abrangidas } \\
\text { pela } \\
\text { Diretiva }\end{array}$ & $\begin{array}{c}\text { Identificadas } \\
\text { em anexo } \\
\text { no acordo }\end{array}$ & $\begin{array}{c}\text { Sob controlo } \\
\text { da } \\
\text { multinacional }\end{array}$ & $\begin{array}{c}\text { Com pelo } \\
\text { menos } 100 \\
\text { trabalhadores }\end{array}$ & $\begin{array}{c}\text { Não } \\
\text { referido }\end{array}$ & Total \\
\hline $\mathbf{N}$ & 20 & 44 & 9 & 10 & 18 & 3 & 7 & 111 \\
\hline$\%$ & $18 \%$ & $39,6 \%$ & $8,1 \%$ & $9,0 \%$ & $16,2 \%$ & $2,7 \%$ & $6,3 \%$ & $100,0 \%$ \\
\hline
\end{tabular}

Fonte: European Works Councils Database 2011 
Legislação aplicável, igual ou diferente à do país de origem, por país, no e fora do EEE (valores absolutos)

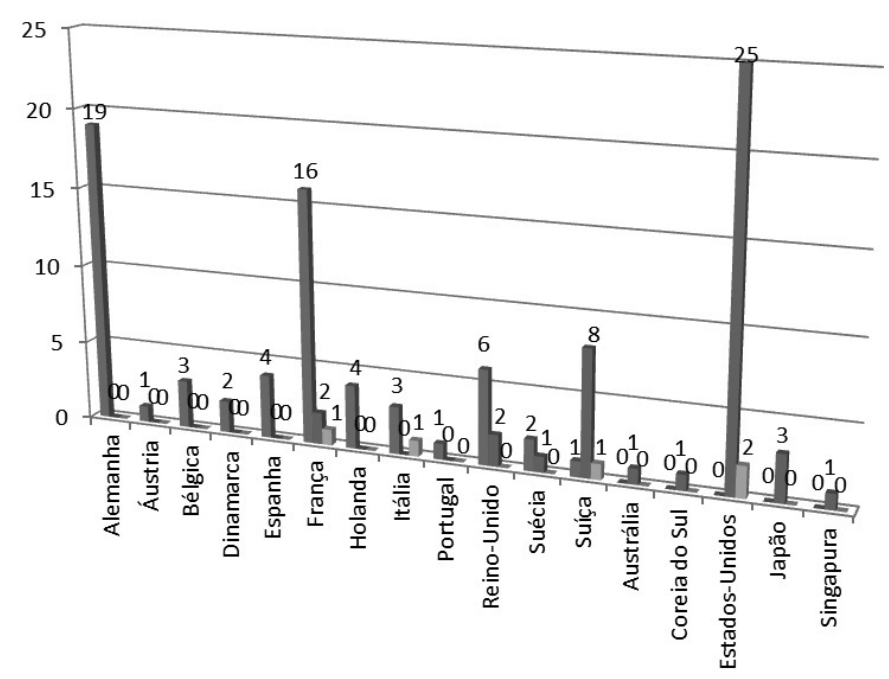

— Igual à do país de origem घ Diferente do país de origem não referido

Fonte: European Works Councils Database 2011

GRÁFICO 19

Alcance geográfico dos acordos (sucursais abrangidas)

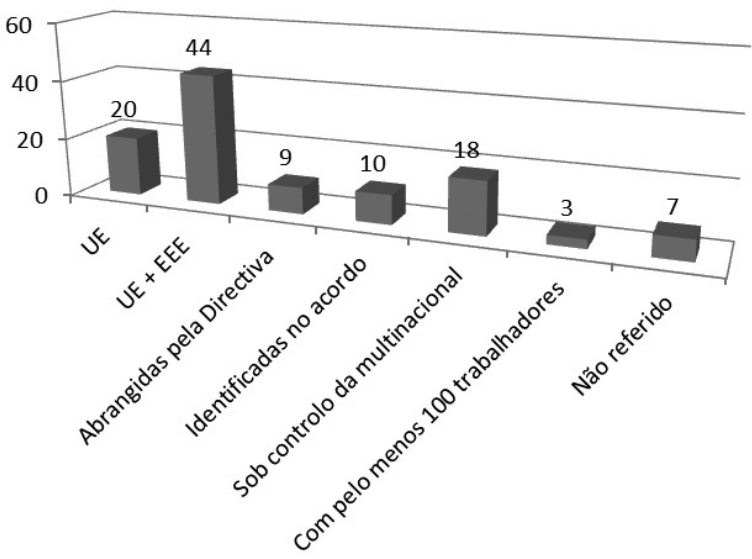

Fonte: European Works Councils Database 2011 


\subsection{Duração}

A validade dos acordos varia entre um período indefinido ou uma validade que vai de um a sete anos. No entanto, os acordos válidos por um período indefinido ou com uma duração de quatro anos são os casos mais frequentes no conjunto dos acordos analisados, respetivamente com 52 e 39 acordos (ver quadro 19 e gráfico 20). Mas assinale-se igualmente a elevada percentagem (cerca de 53\%) de acordos celebrados com base no artigo $13 .^{\circ}$ da Diretiva 94/45/CE, ou seja, numa base voluntária e com um período de duração indefinido. Daí que este aspeto tenha suscitado também o processo de revisão da anterior Diretiva dos CEEs, de modo a que os acordos celebrados com base no artigo $13 .^{\circ}$ que não tivessem previsto um período de duração o passassem a contemplar. A renegociação de acordos aparece, de facto, como uma oportunidade para incorporar aspetos não incluídos inicialmente nos acordos voluntários.

QUADro 19 - Período de duração dos acordos

\begin{tabular}{|c|c|c|c|c|c|}
\cline { 2 - 6 } \multicolumn{1}{c|}{} & $\mathbf{3}$ ou menos anos & $\mathbf{4}$ anos & $\mathbf{5 - 7}$ anos & Período indefinido & Não referido \\
\hline $\mathbf{N}$ & 5 & 39 & 14 & 52 & 1 \\
\hline$\%$ & $4,5 \%$ & $35,1 \%$ & $12,6 \%$ & $46,8 \%$ & $0,9 \%$ \\
\hline
\end{tabular}

Fonte: European Works Councils Database 2011

\section{Composição, objetivos e competências dos acordos}

\subsection{Composição}

A questão da composição dos CEEs ocupa, regra geral, um espaço considerável tanto no corpus dos acordos como nos anexos, o que se pode explicar, segundo E. Béthoux (2004a: 27), pela importância que a questão da representatividade tem para a legitimidade dos CEEs. O equilíbrio de forças entre representantes dos trabalhadores, representantes da entidade empregadora, representantes sindicais e representantes das 
diversas atividades e/ou setores possivelmente existentes no seio de uma única multinacional afigura-se, pois, crucial para garantir a representatividade e a legitimidade dos CEEs.

GRÁFICO 20

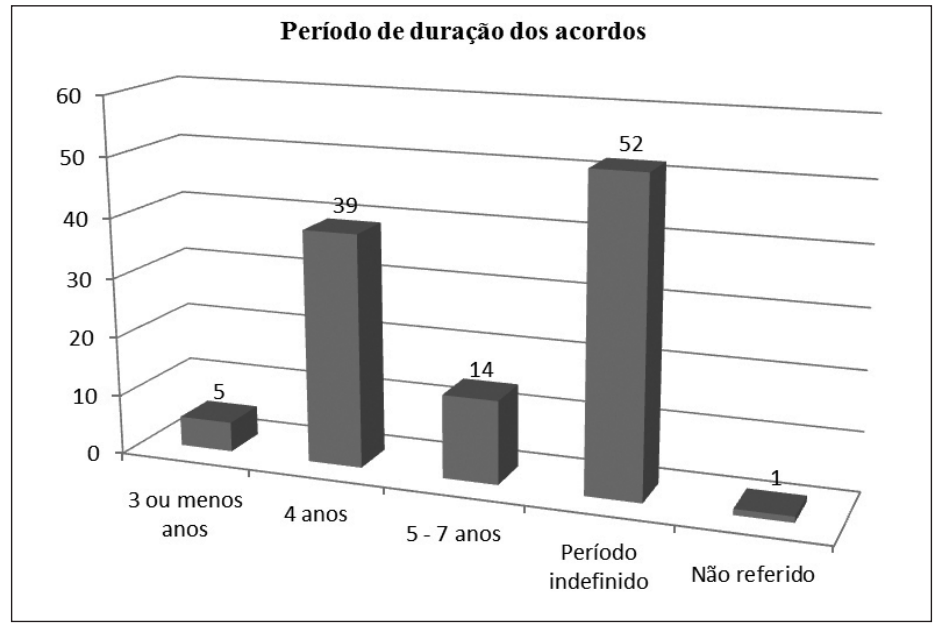

Fonte: European Works Councils Database 2011

Os CEEs instituídos com base nos acordos analisados são maioritariamente "mistos" (ou ditos de modelo francês), ou seja, compostos por representantes dos trabalhadores e por representantes da entidade empregadora (61 acordos ou 55\%). Os CEEs "unilaterais” (modelo germânico), compostos apenas por representantes dos trabalhadores representam, por sua vez, 39,6\% dos acordos (44). Com base nos 111 acordos analisados podemos ainda constatar (quadro 20 e gráfico 21) que apenas um acordo refere explicitamente, note-se, a presença de um representante de uma organização sindical, o que vinha dar razão aos críticos da velha Diretiva (sobretudo às organizações sindicais) que sempre reclamaram um lugar para a representação sindical nos CEEs (como, aliás, se referiu acima, no capítulo 1). O único CEE de um grupo português, o Grupo BES, é composto unicamente por representantes dos trabalhadores. 
QUADro 20 - Composição do CEE

\begin{tabular}{|c|c|c|c|c|c|}
\cline { 2 - 6 } \multicolumn{1}{c|}{} & Unilaterais & Mistos & $\begin{array}{c}\text { Representantes dos trabalhadores } \\
\text { + Representantes de organizações } \\
\text { sindicais }\end{array}$ & $\begin{array}{c}\text { não } \\
\text { referido }\end{array}$ & Total \\
\hline $\mathbf{N}$ & 44 & 61 & 1 & 5 & 111 \\
\hline$\%$ & $39,6 \%$ & $55,0 \%$ & $0,9 \%$ & $4,5 \%$ & $100,0 \%$ \\
\hline
\end{tabular}

Fonte: European Works Councils Database 2011

GRÁFICO 21

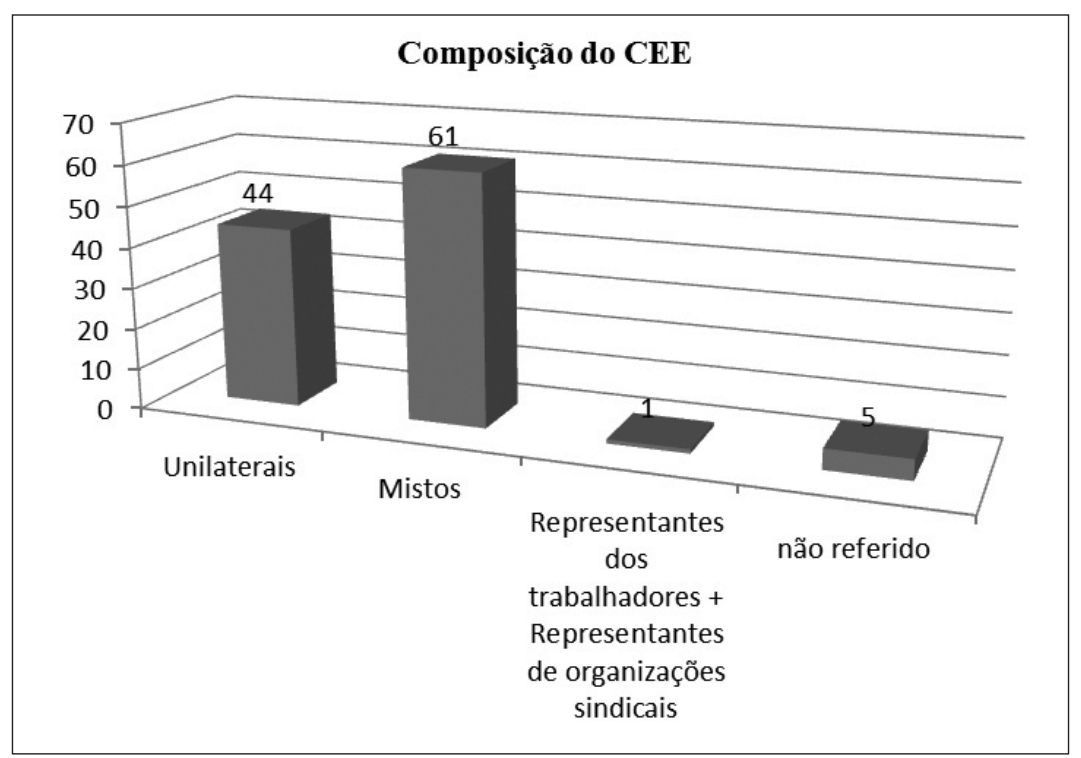

Fonte: European Works Councils Database 2011

A opção por um modelo francês ou germânico é um bom indicador da influência das relações laborais onde se localizam os CEEs (Kerckhofs, 2006: 50). Tal como acontece na generalidade dos CEEs, os países com sistemas de representação dos trabalhadores de inspiração germânica adotaram, tendencialmente, composições unilaterais (Alemanha, Áustria, Holanda, Itália). Já às multinacionais francesas e a maioria das multinacionais com sede fora do EEE optaram pelo modelo misto (gráfico 22). 
GRÁfICO 22

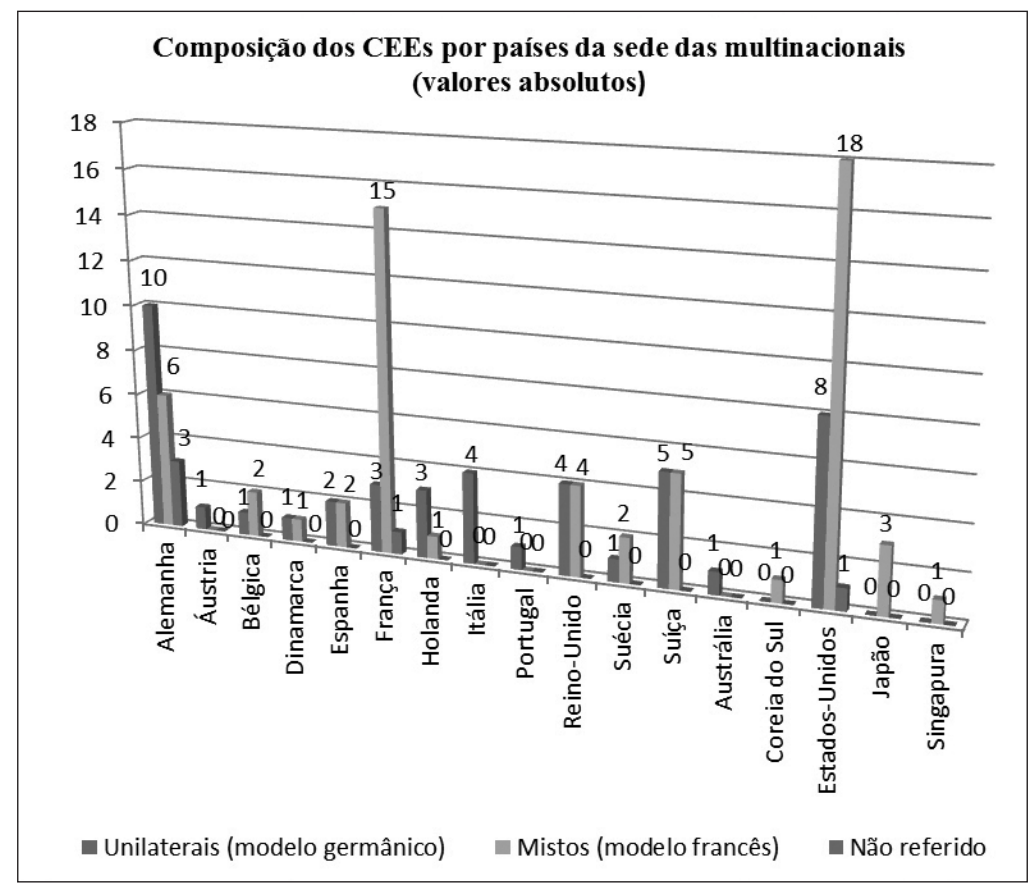

Fonte: European Works Councils Database 2011

Se olharmos para os três setores de atividade em análise relativamente à composição dos CEEs (quadro 21 e gráfico 23) constatamos que apenas o setor químico apresenta uma predominância de CEEs mistos (26 em 39 contabilizados neste setor). Nos outros dois setores, metalúrgico e financeiro, o equilíbrio entre o número de CEEs unilaterais e mistos é o dado mais saliente.

QuAdro 21 - Composição dos CEEs por setores de atividade

\begin{tabular}{|c|c|c|c|c|}
\cline { 2 - 5 } \multicolumn{1}{c|}{} & $\begin{array}{c}\text { Unilaterais (modelo } \\
\text { germânico) }\end{array}$ & $\begin{array}{c}\text { Mistos (modelo } \\
\text { francês) }\end{array}$ & $\begin{array}{c}\text { Não } \\
\text { referido }\end{array}$ & Total \\
\hline Químico & 10 & 26 & 3 & 39 \\
\hline Metalúrgico & 29 & 29 & 0 & 58 \\
\hline Atividades financeiras & 7 & 6 & 2 & 15 \\
\hline
\end{tabular}


GRÁFICO 23

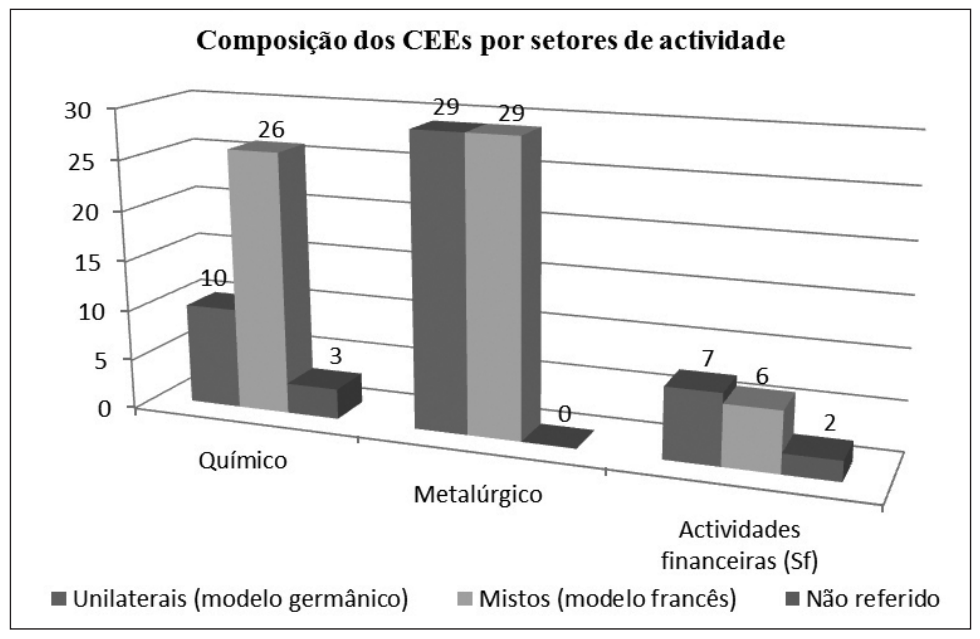

Fonte: European Works Councils Database 2011

\subsection{Objetivos gerais}

No $n .^{\circ} 1$ do art. $1 .^{\circ}$, exatamente como a Diretiva 94/45/CE já estipulara, a Diretiva 2009/38/CE define como sendo seu objetivo "melhorar o direito à informação e consulta dos trabalhadores nas empresas ou grupos de empresas de dimensão comunitária. Ora, na definição dos objetivos gerais dos CEEs, os acordos tendem a cingir-se à Diretiva, definindo-se desse modo os CEEs como instrumentos de troca de informação e consulta sobre questões transnacionais com impacto considerável nos interesses dos trabalhadores.

\subsection{Competências}

Para uma análise das competências dos CEEs, consideram-se aqui os seguintes pontos: as questões objeto de informação e consulta; a referência à oportunidade da informação e consulta; as questões expressamente excluídas da agenda; e a confidencialidade. 


\subsubsection{Informação e consulta}

As questões objeto de informação e consulta mais recorrentes nos acordos dizem respeito: à situação económica e financeira da multinacional; à estrutura e organização; à análise prospectiva; às principais alterações organizacionais e estruturais previstas; às principais tendências ao nível do emprego; aos projetos, investimentos e estratégias da multinacional; aos novos métodos de trabalho, de produção e às novas tecnologias; às transferências, deslocalizações, fusões, aquisições, reduções de pessoal, despedimentos coletivos e encerramentos; e à produção e vendas (produtividade e competitividade). Por outro lado, questões como as condições de trabalho (remunerações, horários de trabalho, etc.); a formação profissional, a saúde, higiene e segurança no trabalho; o ambiente; a igualdade de oportunidades; a legislação europeia; e a representação sindical, só muito esporadicamente constam dos acordos.

Partindo deste leque de questões, é possível estabelecer uma distinção entre acordos que definem as questões a serem objeto de informação e consulta em sede dos CEEs de modo mais circunscrito à letra da Diretiva (classificados como acordos restritos) e acordos mais abrangentes, ou seja, que vão para além do estabelecido na Diretiva (ver quadro 22).

Como se constata no quadro 23 e no gráfico 24 , apesar de não haver uma disparidade muito grande em termos numéricos entre um tipo e outro, a maioria dos acordos enquadra-se no grupo dos acordos restritos, 56 em 111 acordos analisados (50\%). A ausência de outras questões nas agendas dos CEEs revela, de acordo com J. Waddington (2003: 313), a incapacidade dos representantes dos trabalhadores para, no processo de negociação dos acordos, irem além dos requisitos da Diretiva, facto que produzirá impactos certamente distintos nos CEEs. Mas não é difícil de adivinhar que quanto mais restrito for o leque das questões objeto de informação e consulta em sede dos CEEs maior será o desencanto relativamente à participação nestas instituições.

Analisando agora em maior pormenor os acordos classificados como abrangentes, verificamos que esta abrangência se limita, para uma parte significativa dos acordos, a duas questões (25 acordos ou 49\%). Os 
acordos que registam a inclusão de uma e três questões que constam da tipologia acima enunciada surgem, na amostra estudada, como tendo uma representatividade de $22 \%$ cada (11 acordos) (ver quadro 24 e gráfico 25). As questões mais recorrentes dizem respeito à segurança, higiene e saúde no trabalho; ao ambiente; e à formação profissional. Questões como as condições de trabalho (salários, principalmente) e a igualdade de oportunidades são ainda uma raridade no leque das questões a serem debatidas em sede dos CEEs.

QUADro 22 - Tipologia das questões objeto de informação e consulta

\begin{tabular}{|c|c|c|}
\hline \multirow{9}{*}{$\begin{array}{l}\text { Acordos } \\
\text { restritos }\end{array}$} & 1 & Situação económica e financeira \\
\hline & 2 & Estrutura e organização \\
\hline & 3 & Análise prospectiva \\
\hline & 4 & Alterações organizacionais e estruturais \\
\hline & 5 & Principais tendências ao nível do emprego \\
\hline & 6 & Projetos, investimentos e estratégias \\
\hline & 7 & Novos métodos de trabalho e produção/ novas tecnologias \\
\hline & 8 & $\begin{array}{l}\text { Transferências, deslocalizações, fusões, aquisições, cisões, reduções de } \\
\text { pessoal, despedimentos coletivos, encerramentos }\end{array}$ \\
\hline & 9 & Produção e vendas \\
\hline \multirow{7}{*}{$\begin{array}{l}\text { Acordos } \\
\text { abrangentes }\end{array}$} & 10 & $\begin{array}{l}\text { Condições de trabalho (vínculos contratuais, remunerações, horários } \\
\text { laborais, etc.) }\end{array}$ \\
\hline & 11 & Formação profissional \\
\hline & 12 & Segurança, higiene e saúde \\
\hline & 13 & Ambiente \\
\hline & 14 & Igualdade de oportunidades \\
\hline & 15 & Legislação europeia \\
\hline & 16 & Representação sindical \\
\hline
\end{tabular}


QUADRO 23 - Acordos restritos e acordos abrangentes

\begin{tabular}{|c|c|c|c|c|}
\cline { 2 - 5 } \multicolumn{1}{c|}{} & Restritos & Abrangentes & Não referido & Total \\
\hline $\mathbf{N}$ & 56 & 51 & 4 & 111 \\
\hline$\%$ & $50 \%$ & $46 \%$ & $4 \%$ & $100 \%$ \\
\hline
\end{tabular}

Fonte: European Works Councils Database 2011

GRÁFICO 24

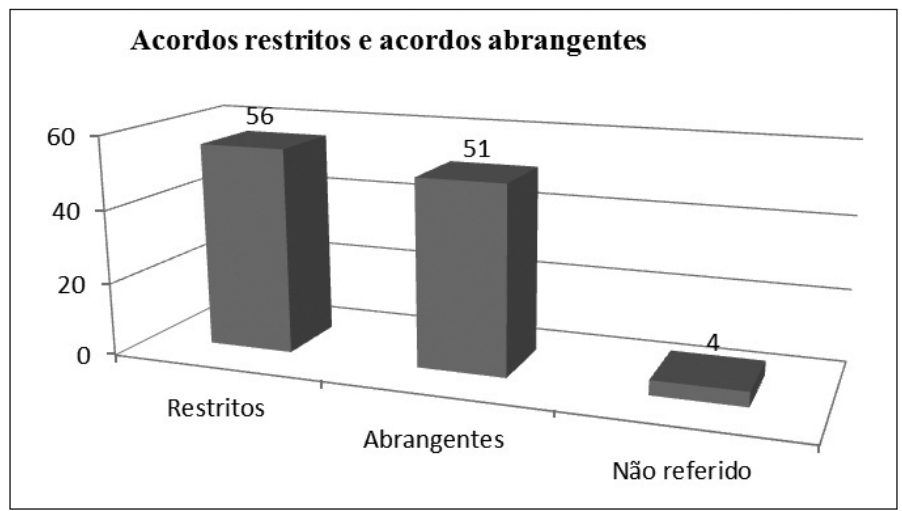

Fonte: European Works Councils Database 2011

QUADRO 24 - Acordos abrangentes, por número de questões incluídas

\begin{tabular}{|c|c|c|c|c|c|c|}
\cline { 2 - 7 } \multicolumn{1}{c|}{} & $\mathbf{1}$ questão & $\mathbf{2}$ questões & $\mathbf{3}$ questões & 4 questões & 5 ou mais questões & Total \\
\hline $\mathbf{N}$ & 11 & 25 & 11 & 4 & 0 & 51 \\
\hline$\%$ & $22 \%$ & $49 \%$ & $22 \%$ & $8 \%$ & $0 \%$ & $100 \%$ \\
\hline
\end{tabular}

Fonte: European Works Councils Database 2011

A repartição de acordos restritos e abrangentes pelos países da sede das multinacionais não evidencia grandes variações (gráfico 26). Já relativamente aos setores de atividade, podemos encontrar, no setor metalúrgico, uma diferença com alguma expressão entre acordos restritos (35 acordos) e abrangentes (23 acordos). Nos outros dois setores a distribuição 
GRÁFICO 25

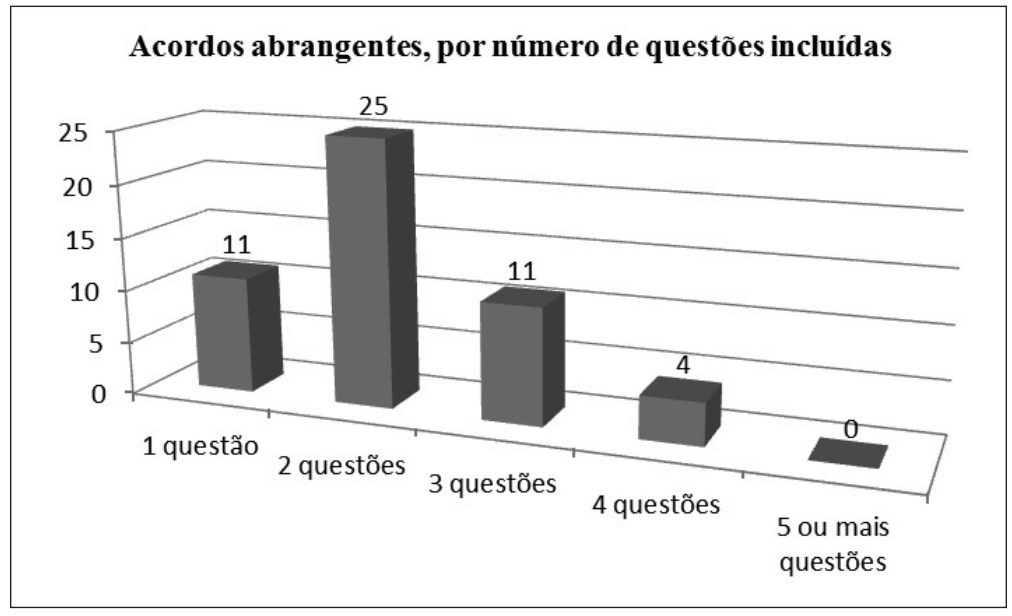

Fonte: European Works Councils Database 2011

GRÁFICO 26

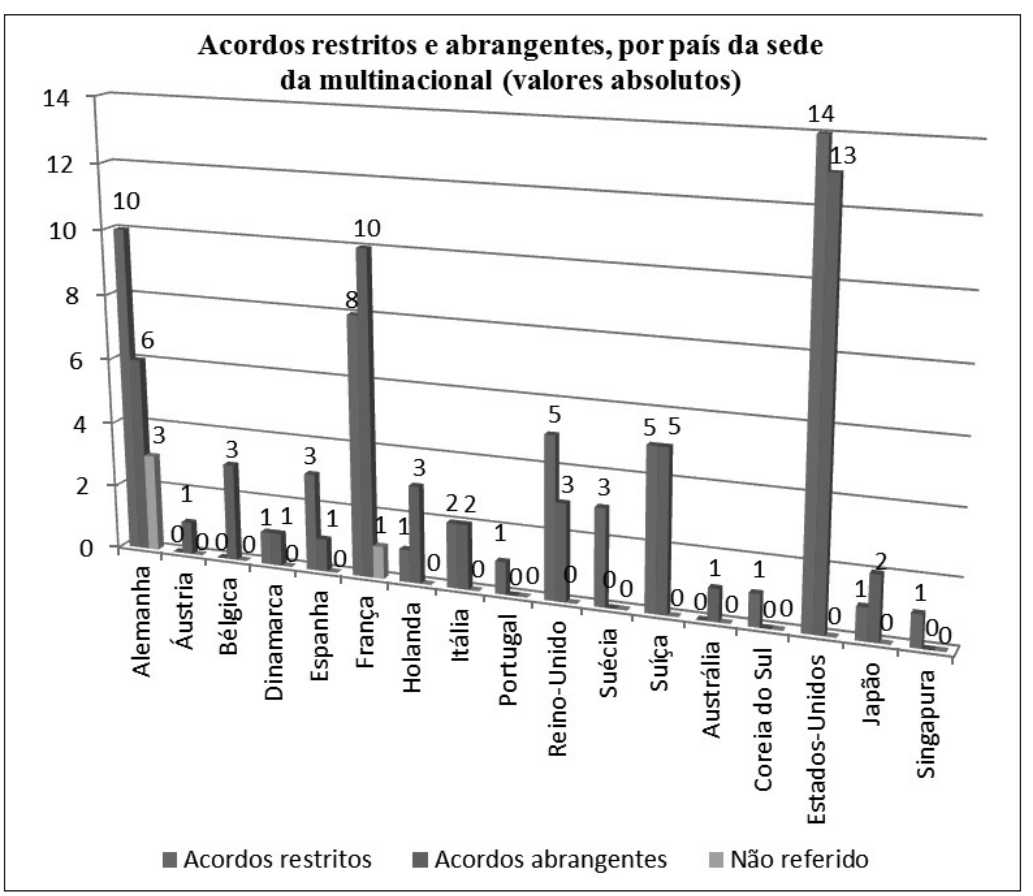

Fonte: European Works Councils Database 2011 
dos acordos por estas duas categorias é mais equilibrada (gráfico 27). A formação profissional, a segurança, a saúde e higiene no trabalho, e o ambiente são questões transversais a todos os setores. As condições de trabalho surgem referenciadas no setor metalúrgico, ao passo que a igualdade de oportunidades aparece como referência dos acordos das multinacionais do setor financeiro, na linha, aliás, do que fora sublinhado por Costa e Araújo (2009: 84).

GRÁFICO 27

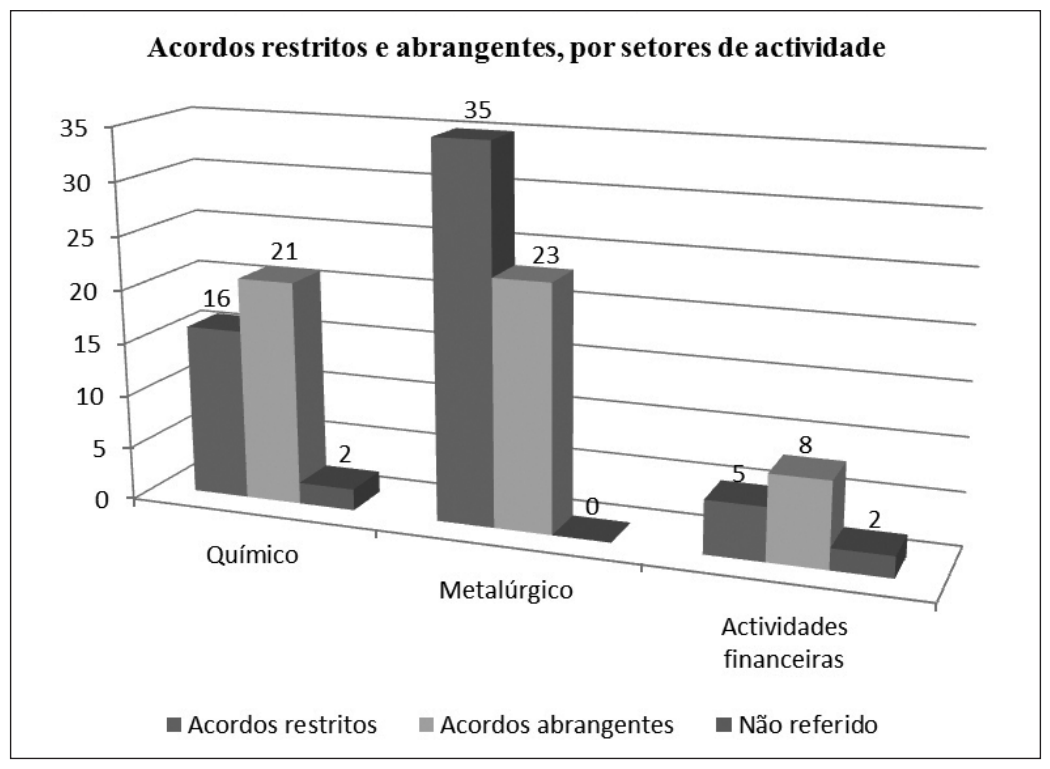

Fonte: European Works Councils Database 2011

No que diz respeito ao tipo de acordo, há alguma preponderância de acordos restritos celebrados com base no artigo $6 .^{\circ}$ e um número reduzido de acordos restritos resultantes de reformulações ou pós-fusões (quadro 25). Este facto pode indiciar que, uma vez reformulados, os novos acordos celebrados ao abrigo do artigo $6 .^{\circ}$ tenham tendência a tornar-se mais abrangentes, ou seja, tenham o cuidado de incorporar um leque mais amplo de questões que fujam ao estipulado pela Diretiva. 
QUADRO 25 - Acordos restritos e abrangentes, por tipo de acordo

\begin{tabular}{|l|c|c|c|c|}
\hline \multicolumn{1}{|c|}{ Tipo de acordo } & $\begin{array}{c}\text { Acordos } \\
\text { restritos }\end{array}$ & $\begin{array}{c}\text { Acordos } \\
\text { abrangentes }\end{array}$ & $\begin{array}{c}\text { Não } \\
\text { referido }\end{array}$ & Total \\
\hline Artigo 13. ${ }^{\circ}$ (acordos voluntários) & 15 & 15 & 0 & 30 \\
\hline $\begin{array}{l}\text { Artigo 13. } \\
\text { pós-fusão) }\end{array}$ & 16 & 12 & 1 & 29 \\
\hline Artigo 6. $^{\circ}$ (acordos reformulados ou & 22 & 16 & 1 & 39 \\
\hline $\begin{array}{l}\text { Artigo 6. } \\
\text { pós-fusão) }\end{array}$ & 3 & 8 & 2 & 13 \\
\hline
\end{tabular}

Fonte: European Works Councils Database 2011

QUADRO 26 - Menção à oportunidade da informação e consulta

\begin{tabular}{|c|c|c|c|c|}
\cline { 2 - 5 } \multicolumn{1}{c|}{} & Sim & Não & Não referido & Total \\
\hline $\mathbf{N}$ & 38 & 69 & 4 & 111 \\
\hline$\%$ & $34,2 \%$ & $62,2 \%$ & $3,6 \%$ & $100,0 \%$ \\
\hline
\end{tabular}

Fonte: European Works Councils Database 2011

\subsubsection{Oportunidade da informação e consulta}

Um dos aspetos que é frequentemente realçado nos estudos sobre o funcionamento dos CEEs prende-se com os défices de oportunidade da informação e consulta que existem na prática destes órgãos, por sinal designados de informação e consulta. São reduzidos os acordos que fazem referência explícita ao facto de a informação e consulta deverem ser realizadas em tempo útil, ou seja, previamente à tomada de qualquer decisão suscetível de afetar os interesses dos trabalhadores. Este facto, que vem reforçar as críticas ao modo como a consulta está a ser realizada pelas multinacionais (Buschak, 1999a: 386-7; Wills, 2001: 191; 2004: 96; Hall, 2003: 6) e ao qual, de resto, já se fez alusão nos capítulos anteriores, é constatável em apenas 38 dos 111 acordos estudados (34,2\%). Uma minoria, portanto, perante os 69 acordos $(62,2 \%)$ que não fazem referência à oportunidade da informação e consulta (quadro 26). 
De resto, nalguns acordos está explicitamente estabelecido que a direção central e/ou respetivas sucursais são os únicos órgãos competentes para sugerir/implementar decisões.

\subsubsection{Questões expressamente excluídas dos acordos}

Como se atesta pelo quadro seguinte, cerca de metade dos acordos analisados (56) fazem referência explícita a questões que não podem ser objeto de informação e consulta em sede dos CEEs. As matérias mais recorrentes dizem respeito: aos problemas relacionados com unidades nacionais isoladamente e às questões potencialmente prejudiciais para a multinacional.

QUADRO 27 - Questões expressamente excluídas

\begin{tabular}{|c|c|c|}
\hline & $\mathbf{N}$ & $\%$ \\
\hline Relacionadas com unidades nacionais & 24 & $21,6 \%$ \\
\hline Potencialmente prejudiciais para a multinacional & 10 & $9,0 \%$ \\
\hline Relacionadas com unidades nacionais + Potencialmente prejudiciais & 8 & $7,2 \%$ \\
\hline $\begin{array}{l}\text { Relacionadas com unidades nacionais + Potencialmente prejudiciais + } \\
\text { Remunerações, compensações, benefícios e condições de trabalho }\end{array}$ & 4 & $3,6 \%$ \\
\hline $\begin{array}{l}\text { Relacionadas com unidades nacionais + Remunerações, compensações, } \\
\text { benefícios e condições de trabalho }\end{array}$ & 2 & $1,8 \%$ \\
\hline Relacionadas com unidades nacionais + Negociação coletiva & 1 & $0,9 \%$ \\
\hline Outras situações* & 7 & $6,3 \%$ \\
\hline Não referido & 55 & $49,5 \%$ \\
\hline Total & 111 & $100,0 \%$ \\
\hline
\end{tabular}

* Incluem combinações variáveis de questões expressamente excluídas (nacionais, potencialmente prejudiciais, negociação coletiva e condições de trabalho).

Fonte: European Works Councils Database 2011

Igualmente na linha do que é sustentado por Costa e Araújo (2009: 84), sendo o objetivo da Diretiva melhorar o direito dos trabalhadores à informação e consulta transnacionais, é compreensível que sejam mais 
frequentemente excluídas das agendas e competências dos CEEs as questões respeitantes às unidades nacionais (24 acordos ou 21,6\%). Porém, apesar desta reserva, alguns acordos salvaguardam a possibilidade de, em circunstâncias excecionais (reestruturações, deslocalizações, encerramentos, despedimentos coletivos, etc.), se realizarem encontros entre os representantes dos trabalhadores da unidade afetada, os representantes dos trabalhadores do CEE e a direção central. A própria Diretiva prevê, de resto, a realização de reuniões extraordinárias para esse efeito.

Embora os acordos prevejam que os representantes dos trabalhadores nos CEEs, bem como os peritos ou convidados, devam manter confidenciais as informações comunicadas como tais durante e após o seu mandato, nalguns acordos as direções centrais reservam-se o direito de não divulgar informação que possa ser potencialmente prejudicial para a multinacional (10 acordos ou 9\%). Esta disposição está, aliás, salvaguardada na Diretiva que prevê que "em casos específicos e nos termos e limites fixados na legislação nacional, cada Estado-membro deve dispor que a direção central situada no seu território não é obrigada a comunicar as informações cuja natureza seja suscetível, segundo critérios objetivos, de entravar gravemente o funcionamento das empresas em causa ou de as prejudicar" (artigo 8..$^{\circ}$ n. ${ }^{\circ} 2$ da Diretiva 2009/38/CE). A confidencialidade constitui um problema sobretudo se contribuir para paralisar a ação dos representantes dos trabalhadores. Porém, os representantes reconhecem alguma legitimidade na não divulgação de informação potencialmente prejudicial para a multinacional.

\subsubsection{Confidencialidade}

Na verdade, a questão da confidencialidade, como já se foi dizendo, está prevista no artigo $8 .^{\circ}$ da Diretiva dos CEEs em vigor, designadamente no ponto 1. Neste ponto, é dito que "os Estados-membros devem dispor que os membros do grupo especial de negociação e do conselho de empresa europeu, bem como os peritos que eventualmente os assistam, não são autorizados a revelar a terceiros as informações que lhes 
tenham sido expressamente comunicadas a título confidencial. O mesmo se aplica aos representantes dos trabalhadores no âmbito de um procedimento de informação e consulta. Esta obrigação mantém-se seja qual for o local em que os representantes se encontrem, mesmo após o termo dos respetivos mandatos".

O que a análise dos acordos nos revela é que a questão da confidencialidade se encontra explicitamente prevista em 97 dos 111 acordos, ou seja, em $87,4 \%$ dos acordos (ver quadro 28 e gráfico 28). Trata-se de uma maioria esmagadora, bem reveladora das cautelas das multinacionais quanto à proteção dos seus interesses, por vezes mesmo quando os assuntos não o justificariam.

QUADRO 28 - Confidencialidade

\begin{tabular}{|c|c|c|c|}
\cline { 2 - 4 } \multicolumn{1}{c|}{} & Prevista & Não referido & Total \\
\hline $\mathbf{N}$ & 97 & 14 & 111 \\
\hline$\%$ & $87,4 \%$ & $12,6 \%$ & $100,0 \%$ \\
\hline
\end{tabular}

Fonte: European Works Councils Database 2011

GRÁFICO 28

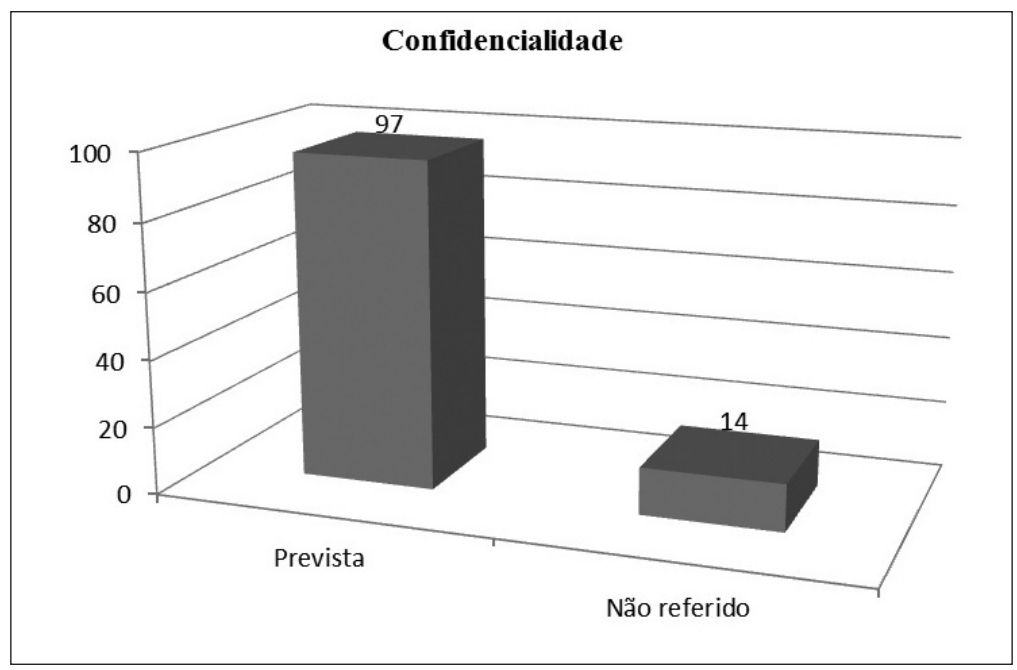

Fonte: European Works Councils Database 2011 


\section{Representantes e seleção dos representantes dos trabalhadores}

Relativamente aos representantes dos trabalhadores e à sua seleção para o CEE, são aqui objeto de análise os seguintes pontos: os critérios de atribuição dos lugares; os requisitos necessários para se poder ser eleito/nomeado para a representação dos trabalhadores; a duração dos mandatos; a formação dos representantes; e a proteção garantida aos representantes.

\subsection{Os critérios de atribuição dos lugares}

Como referem Costa e Araújo (2009: 91-93), como forma de assegurar a funcionalidade dos CEEs alguns acordos estabelecem um limite máximo de representantes dos trabalhadores - que se situa, em média, em torno dos trinta representantes - desde que seja assegurada a efetiva representação dos trabalhadores abrangidos pelo acordo. A questão da repartição dos lugares no seio dos CEEs não se resume, porém, ao problema do equilíbrio geográfico ou nacional. Paralelamente a esta, encontram-se as questões do equilíbrio sindical (Costa, 2005) e da representação das diferentes atividades de uma dada multinacional. A organização da representação destas atividades e a instauração de um diálogo entre os seus representantes assume, assim, particular importância quer para a questão da representatividade do CEE, quer para o reforço da sua legitimidade (Béthoux, 2004a: 28). Ora, uma vez que os critérios de atribuição de lugares pelos países onde a multinacional detém sucursais depende, na grande maioria dos acordos, do número de trabalhadores, parte dos acordos prevê que o limite máximo de representantes possa ser alterado caso se verifiquem mudanças significativas na estrutura de emprego da multinacional (fusões, aquisições, dissoluções, reestruturações, etc.). Os processos de reestruturação colocam, a este propósito, um duplo desafio aos CEEs: por um lado, ao nível da influência que os CEEs poderão ter efetivamente nos processos em curso (Béthoux, 2004b; Moreau, 2006); por outro, ao nível da influência que os processos de reestruturação terão nos CEEs. 
A atribuição de lugares por país baseia-se maioritariamente na estrutura de emprego nacional (número de trabalhadores existentes a nível nacional). Desta forma, são definidos intervalos ou quotas, aumentando o número de representantes à medida que aumenta o intervalo de trabalhadores. Por exemplo, há CEEs onde, de 30 a 100 trabalhadores, é atribuído 1 mandato; de 101 a 300, 2 mandatos; de 301 a 400, 3 mandatos; e mais de 401, 4 mandatos. Nestes casos, é comum os acordos estabelecerem um limiar, que se situa em geral em torno dos 100 trabalhadores, a partir do qual as sucursais abrangidas poderão eleger/nomear representantes para os CEEs. Outra situação possível para a distribuição de lugares consiste em definir lugares fixos para cada uma das filiais abrangidas pelo acordo, sendo estes lugares, regra geral, estipulados no anexo ao acordo. É igualmente frequente que os países da sede da multinacional reservem para si mesmos um número fixo de representantes. O acordo do CEE do Grupo BES, por exemplo, estabelece 10 mandatos para os representantes portugueses e um único para a representação espanhola. Afinal, o protagonismo dos representantes dos trabalhadores das sedes das multinacionais dos CEEs - que decorre do acesso privilegiado à informação - suscita alguma crispação nas relações entre os membros dos CEEs e impulsiona a busca de alianças estratégicas entre membros como forma de repor alguma simetria nas relações de poder (Costa e Araújo, 2009: 93).

\subsection{Requisitos para ser eleito/nomeado representante}

A análise dos acordos permite concluir que muitos estabelecem determinados requisitos que os representantes dos trabalhadores devem cumprir para poderem ser eleitos/nomeados (quadro 29 e gráfico 29). As duas situações detetadas mais frequentes são as seguintes: por um lado, em 47 acordos $(42,3 \%)$ os representantes dos trabalhadores devem ser eleitos/nomeados segundo os procedimentos vigentes a nível nacional; por outro lado, em 30 acordos (27\%) devem ser eleitos/nomeados pelos órgãos de representação existentes a nível nacional ou, no caso de não existirem, de acordo com os procedimentos vigentes a nível nacional. 
QUADRO 29 - Requisitos para a eleição/nomeação dos representantes

\begin{tabular}{|c|c|c|c|c|c|c|c|c|}
\hline & $\begin{array}{l}\text { Procedi- } \\
\text { mentos } \\
\text { vigentes } \\
\text { a nível } \\
\text { nacional }\end{array}$ & $\begin{array}{c}\text { Procedi- } \\
\text { mentos } \\
\text { vigentes } \\
\text { a nível } \\
\text { nacional + } \\
\text { Tempo de } \\
\text { serviço de } \\
\text { pelo me- } \\
\text { nos } 1 \text { ano }\end{array}$ & $\begin{array}{c}\text { Procedi- } \\
\text { mentos } \\
\text { vigentes } \\
\text { a nível } \\
\text { nacional + } \\
\text { Tempo de } \\
\text { serviço de } \\
\text { pelo menos } \\
2 \text { anos }\end{array}$ & $\begin{array}{c}\text { Procedi- } \\
\text { mentos } \\
\text { vigentes } \\
\text { a nível } \\
\text { nacional + } \\
\text { Tempo de } \\
\text { serviço de } \\
\text { pelo menos } \\
3 \text { anos }\end{array}$ & $\begin{array}{c}\text { Eleitos/ } \\
\text { nome- } \\
\text { ados } \\
\text { pelos } \\
\text { órgãos } \\
\text { de repre- } \\
\text { sentação } \\
\text { nacio- } \\
\text { nais }\end{array}$ & $\begin{array}{c}\text { Outras } \\
\text { situa- } \\
\text { ções* }\end{array}$ & $\begin{array}{c}\text { Não } \\
\text { referido }\end{array}$ & Total \\
\hline $\mathbf{N}$ & 47 & 6 & 5 & 2 & 30 & 2 & 19 & 111 \\
\hline$\%$ & $42,3 \%$ & $5,4 \%$ & $4,5 \%$ & $1,8 \%$ & $27,0 \%$ & $1,8 \%$ & $17,1 \%$ & $100,0 \%$ \\
\hline
\end{tabular}

* Inclui situações em que são tidos como requisitos o domínio da língua inglesa e um contrato de trabalho a tempo inteiro.

Fonte: European Works Councils Database 2011

GRÁFICO 29

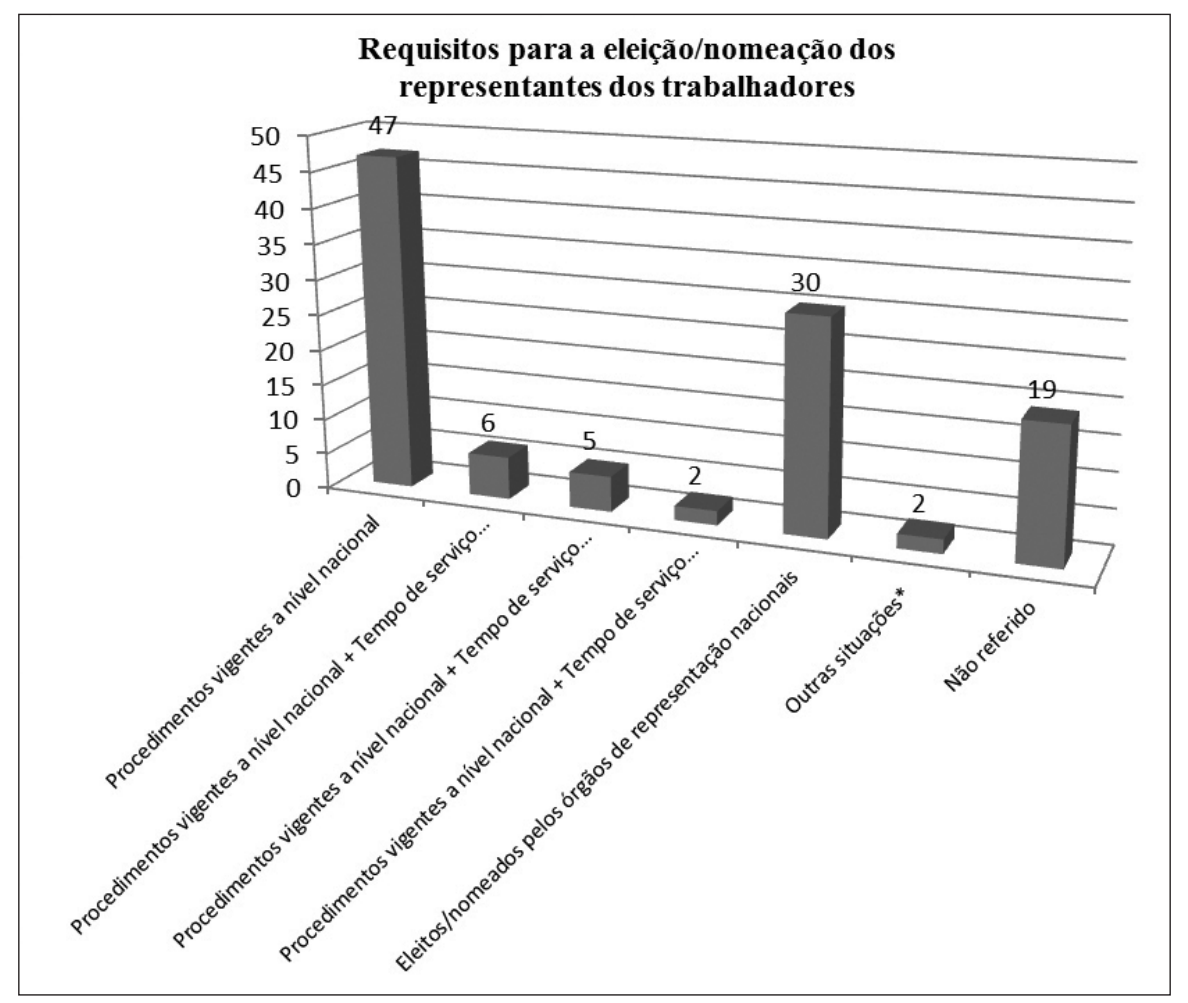

Fonte: European Works Councils Database 2011 


\subsection{Duração dos mandatos}

Não foi aqui analisada a questão da duração dos mandatos do ponto

de vista setorial. No entanto, não estaremos longe da tendência geral assinalada por Costa e Araújo (2009: 94), segundo a qual os representantes dos trabalhadores cumprem, maioritariamente mandatos de quatro anos, seguindo-se os mandatos de três e de dois anos. Apenas o acordo do grupo italiano Generali (setor financeiro) estabelece a duração de um mandato de seis anos e, no outro extremo, a multinacional norte-americana Cooper Industries (setor metalúrgico) mandatos de um único ano. O cumprimento de mandatos longos pode conferir, na ótica de E. Béthoux (2004a: 29), alguma estabilidade nas relações entre os membros dos CEEs e, deste modo, ser potenciadora de coesão e unidade no seio dos CEEs. A este respeito, o acordo da multinacional holandesa Akzo-Nobel (setor químico), por exemplo, refere-se explicitamente a este facto, estabelecendo mandatos de quatro anos como a única forma de assegurar continuidade e de garantir uma participação eficiente por parte dos representantes.

\subsection{Formação dos representantes}

Sobre o modo como é tratado nos acordos o requisito da formação dos representantes dos trabalhadores (ver quadro 30 e gráfico 30), foram detetadas nos acordos analisados três situações dignas de nota. Em primeiro lugar, o elevado número de acordos que simplesmente não fazem qualquer menção à formação dos representantes ( 49 acordos ou 44,1\%). Em segundo lugar, a formação em Línguas que aparece isoladamente em 20 acordos (18\%). Em terceiro lugar, a referência à formação de uma forma ambígua: aquela que é necessária para que os representantes desempenhem adequadamente as suas funções no âmbito dos CEEs (18 acordos ou $16,2 \%)$.

$\mathrm{Na}$ questão da formação, o facto de haver uma preocupação com o domínio da língua inglesa por parte dos representantes dos trabalhadores reforça o peso do inglês enquanto língua franca dos CEEs. Daí que 
a aposta neste domínio formativo possa reforçar a funcionalidade dos CEEs e, em simultâneo, reduzir despesas com a tradução de documentos e com a interpretação simultânea durante as reuniões.

QUADRO 30 - Formação dos representantes dos trabalhadores

\begin{tabular}{|c|c|c|c|c|c|c|}
\hline & Indefinida & $\begin{array}{c}\text { Necessária } \\
\text { às funções }\end{array}$ & Línguas & $\begin{array}{c}\text { Outras } \\
\text { situações* }\end{array}$ & Não referido & Total \\
\hline $\mathbf{N}$ & 4 & 18 & 20 & 20 & 49 & 11 \\
\hline$\%$ & $3,6 \%$ & $16,2 \%$ & $18,0 \%$ & $18,0 \%$ & $44,1 \%$ & $100,0 \%$ \\
\hline
\end{tabular}

* Inclui combinações diversas entre a formação em línguas; questões económicas, jurídicas e sociais europeias; e a estrutura e atividades da multinacional.

Fonte: European Works Councils Database 2011

GRÁFICO 30

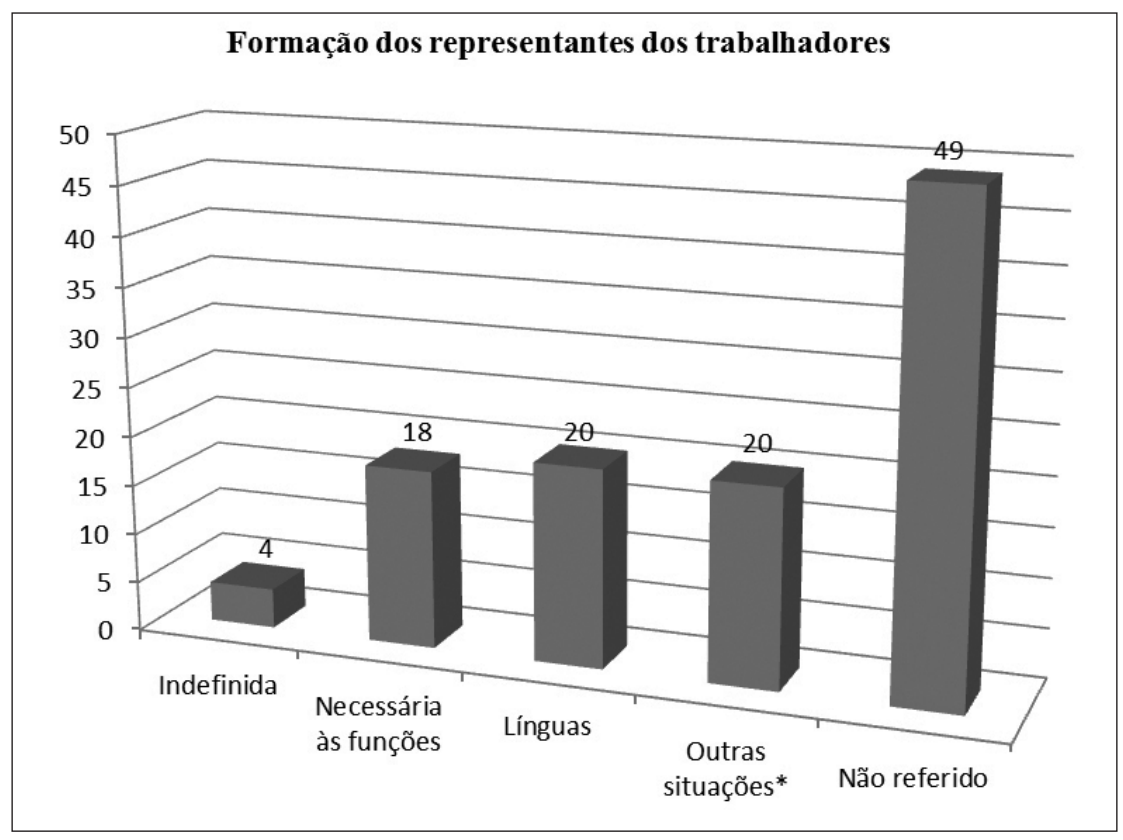

Fonte: European Works Councils Database 2011 


\subsection{Proteção aos representantes}

A proteção dos representantes consta do artigo $100^{\circ}$ da Diretiva em vigor, que confere aos membros do GEN ou dos CEEs proteções e garantias semelhantes às previstas para os representantes dos trabalhadores na legislação e/ou práticas nacionais: pagamento das horas de trabalho durante os períodos de ausência necessários ao exercício de funções relacionadas com os CEEs. Segundo Costa e Araújo (2009: 95), a proteção dos representantes dos trabalhadores consta de cerca de $64 \%$ dos acordos.

\section{Reuniões dos Conselhos de Empresa Europeus}

O momento das reuniões é aquele onde "tudo" acontece, não só do ponto de vista formal como quanto a informações que se vão adquirindo pela via informal. Mas é claro que os acordos incorporam sobretudo os aspetos formais, tais como os tempos das reuniões e todas as questões relacionadas com o seu normal funcionamento.

\subsection{Reuniões ordinárias, preparatórias, posteriores e extraordinárias}

A realização de uma única reunião anual é vista negativamente pelos representantes dos trabalhadores (Costa e Araújo, 2009: 95). Com efeito, a grande maioria dos acordos $(77,5 \%)$ prevê a realização de uma única reunião anual, cuja duração só excecionalmente excede um dia e nunca se estende por mais de dois dias.

QUADro 31 - Frequência das reuniões ordinárias dos CEEs

\begin{tabular}{|c|c|c|c|c|c|}
\cline { 2 - 6 } \multicolumn{1}{c|}{} & $\mathbf{1}$ vez por ano & 2 vezes por ano & 4 vezes por ano & Não referido & Total \\
\hline $\mathbf{N}$ & 86 & 20 & 2 & 3 & 111 \\
\hline$\%$ & $77,5 \%$ & $18,0 \%$ & $1,8 \%$ & $2,7 \%$ & $100,0 \%$ \\
\hline
\end{tabular}

Fonte: European Works Councils Database 2011 
Quanto à existência de reuniões preparatórias e posteriores, 55\% dos acordos prevê apenas a realização de reuniões preparatórias e $29,7 \%$ a realização de reuniões anteriores e posteriores à reunião anual (quadro 32). De referir que a possibilidade dos representantes dos trabalhadores se encontrarem antes da reunião formal (entre si e com representantes da entidade empregadora), é um aspeto valorizado pelos representantes (Costa e Araújo, 2009: 96), como de resto se verá adiante nos estudos de caso.

QUADRO 32 - Reuniões preparatórias e posteriores

\begin{tabular}{|c|c|c|c|c|c|}
\cline { 2 - 6 } \multicolumn{1}{c|}{} & Preparatórias & Posteriores & $\begin{array}{c}\text { Preparatórias }+ \\
\text { Posteriores }\end{array}$ & $\begin{array}{c}\text { Não } \\
\text { referido }\end{array}$ & Total \\
\hline $\mathbf{N}$ & 61 & 1 & 33 & 16 & 111 \\
\hline$\%$ & $55,0 \%$ & $0,9 \%$ & $29,7 \%$ & $14,4 \%$ & $100,0 \%$ \\
\hline
\end{tabular}

Fonte: European Works Councils Database 2011

\subsection{Lingua franca, tradução de documentos e interpretação simultânea}

A língua de trabalho dos CEEs que consta dos acordos reflete quer a variedade linguística da Europa e o peso do Inglês, do Alemão e do Francês no espaço europeu, quer o facto de o Inglês se ter tornado a língua franca das relações laborais transnacionais e do capitalismo internacional (Crystal, 1997; Miller et al, 2000: 312; Costa e Araújo, 2009: 97).

A análise dos acordos revela que, na maioria dos casos, a língua nativa do país sede da multinacional é a língua de referência do respetivo CEE (64 acordos ou 57,7\%). Quando a língua de referência dos CEEs é diferente da língua do país da sede (30 acordos ou 27\%) e nos casos em que à língua do país da sede se associa outra língua (10 acordos ou 9\%), é a língua inglesa que, regra geral, serve de língua de trabalho. 
QUADRO 33 - Língua de referência

\begin{tabular}{|c|c|c|c|c|c|}
\cline { 2 - 6 } \multicolumn{1}{c|}{} & $\begin{array}{c}\text { Igual à do país } \\
\text { da sede da } \\
\text { multinacional }\end{array}$ & $\begin{array}{c}\text { Diferente do } \\
\text { país da sede da } \\
\text { multinacional }\end{array}$ & $\begin{array}{c}\text { Igual à do país } \\
\text { da sede + Outra } \\
\text { Língua }\end{array}$ & $\begin{array}{c}\text { Não } \\
\text { referido }\end{array}$ & Total \\
\hline $\mathbf{N}$ & 64 & 30 & 10 & 7 & 111 \\
\hline$\%$ & $57,7 \%$ & $27,0 \%$ & $9,0 \%$ & $6,3 \%$ & $100,0 \%$ \\
\hline
\end{tabular}

Fonte: European Works Councils Database 2011

QUADRO 34 - Língua de referência por país de sede da multinacional

\begin{tabular}{|c|c|c|c|c|c|c|}
\hline & Países & $\begin{array}{c}\text { Igual à do } \\
\text { país de } \\
\text { sede da } \\
\text { multina- } \\
\text { cional }\end{array}$ & $\begin{array}{l}\text { Diferente } \\
\text { do país de } \\
\text { sede da } \\
\text { multina- } \\
\text { cional }\end{array}$ & $\begin{array}{c}\text { Igual à } \\
\text { do país } \\
\text { da sede + } \\
\text { Outra(s) } \\
\text { Língua(s) }\end{array}$ & $\begin{array}{c}\text { Não } \\
\text { referido }\end{array}$ & $\begin{array}{c}\text { Outra(s) } \\
\text { línguas }\end{array}$ \\
\hline \multirow{12}{*}{ EEE } & Alemanha & 15 & 1 & 1 & 2 & Inglês \\
\hline & Áustria & 1 & 0 & 0 & 0 & - \\
\hline & Bélgica & 2 & 1 & 0 & 0 & Inglês \\
\hline & Dinamarca & 0 & 1 & 1 & 0 & Inglês \\
\hline & Espanha & 3 & 1 & 0 & 0 & Inglês \\
\hline & França & 14 & 1 & 3 & 1 & $\begin{array}{l}\text { Inglês e } \\
\text { Alemão }\end{array}$ \\
\hline & Holanda & 0 & 4 & 0 & 0 & - \\
\hline & Itália & 2 & 0 & 1 & 1 & Inglês \\
\hline & Portugal & 1 & 0 & 0 & 0 & - \\
\hline & Reino-Unido & 5 & 2 & 1 & 0 & Escandinavo \\
\hline & Suécia & 0 & 2 & 0 & 1 & - \\
\hline & Suíça & 0 & 9 & 0 & 1 & - \\
\hline \multirow{6}{*}{$\begin{array}{c}\text { Fora } \\
\text { do } \\
\text { EEE }\end{array}$} & Austrália & 0 & 0 & 1 & 0 & Alemão \\
\hline & Coreia do Sul & 0 & 1 & 0 & 0 & Inglês \\
\hline & $\begin{array}{l}\text { Estados- } \\
\text { Unidos }\end{array}$ & 21 & 3 & 2 & 1 & Alemão \\
\hline & Japão & 0 & 3 & 0 & 0 & - \\
\hline & Singapura & 0 & 1 & 0 & 0 & - \\
\hline & Total & 64 & 30 & 10 & 7 & \\
\hline
\end{tabular}


Como se pode constatar pela análise dos acordos (ver gráfico 31), os três principais países que são sede de multinacionais e que, tendencialmente, não adotam a língua de origem são a Suíça, a Holanda e o Japão.

GRÁFICO 31

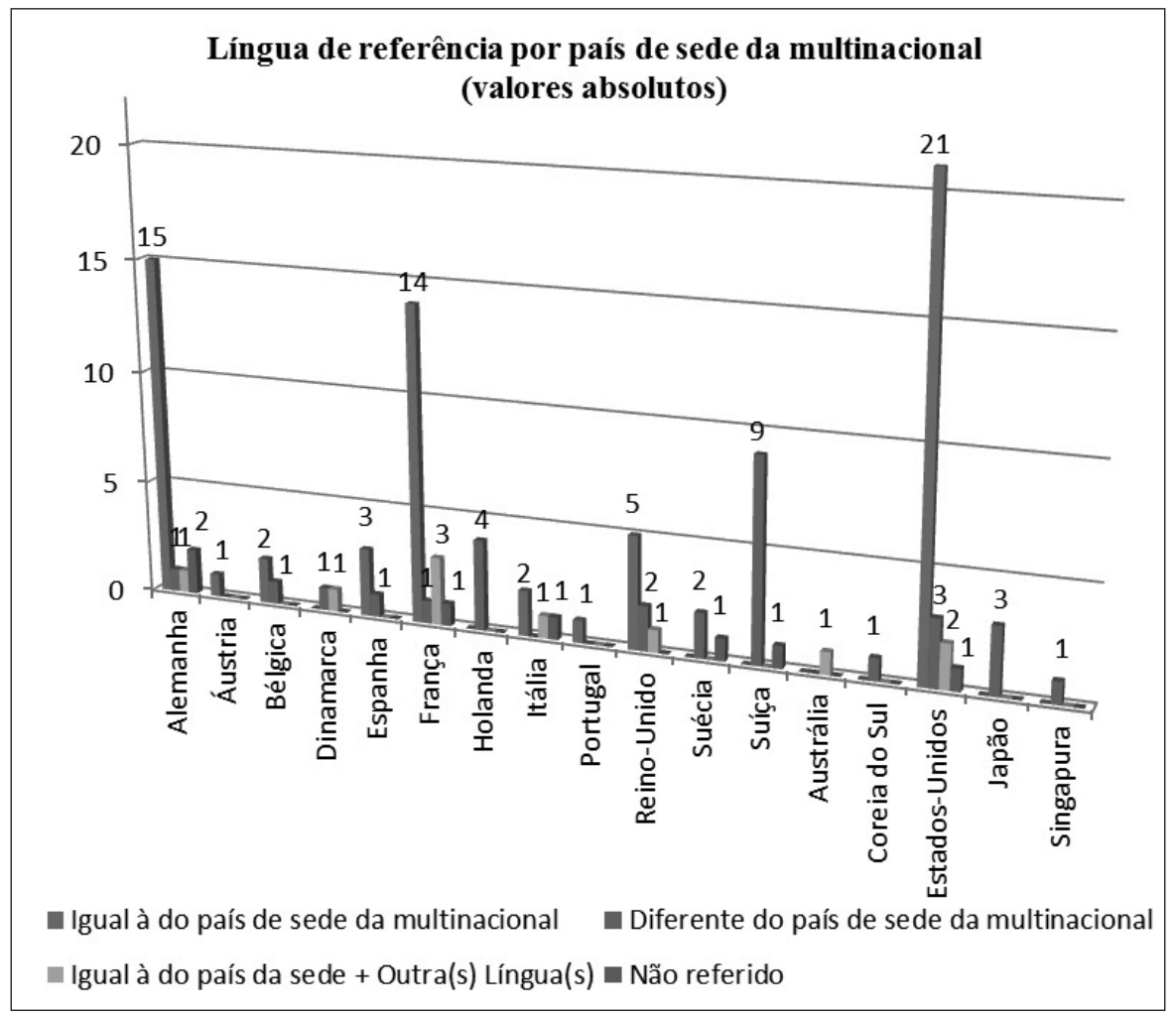

Fonte: European Works Councils Database 2011

Uma parte razoável dos acordos (55,9\%) prevê a tradução e a interpretação como meios auxiliares ao funcionamento das reuniões do CEE. Sempre que a tradução e a interpretação se encontram previstas ou o são para todas as línguas dos países onde a multinacional tem filiais, ou então apenas se incluem algumas línguas, em geral das sucursais com maior número de trabalhadores (ver quadro 35 e gráfico 32). 
QUADRO 35 - Interpretação/tradução

\begin{tabular}{|c|c|c|c|c|c|}
\cline { 2 - 5 } \multicolumn{1}{c|}{} & Prevista & $\begin{array}{c}\text { Prevista } \\
\text { parcialmente* }\end{array}$ & $\begin{array}{c}\text { Outras } \\
\text { situações } * *\end{array}$ & Não referido & Total \\
\hline $\mathbf{N}$ & 62 & 24 & 1 & 24 & 111 \\
\hline$\%$ & $55,9 \%$ & $21,6 \%$ & $0,9 \%$ & $21,6 \%$ & $100,0 \%$ \\
\hline
\end{tabular}

* Reporta-se aos casos em que a interpretação e/ou a tradução de documentos se encontra limitada a um número restrito de línguas.

** Inclui situações como a disponibilidade de interpretação apenas nas duas primeiras reuniões (1 acordo), apenas de parte das reuniões e dos documentos ( 1 acordo), e por um período de três anos ( 2 acordos).

Fonte: European Works Councils Database 2011

GRÁFICO 32

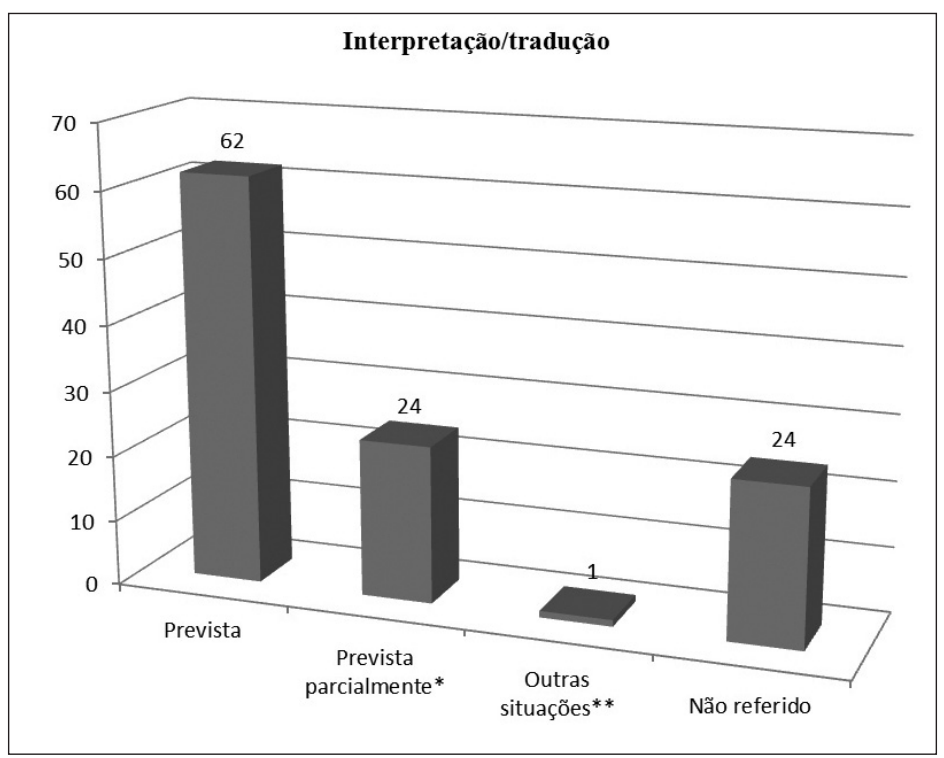

Fonte: European Works Councils Database 2011

As situações mais frequentes dizem respeito à tradução e interpretação condicionadas, ou seja, quando limitadas a um número restrito de línguas (22 acordos ou 14,2\%). A limitação de despesas, suportadas em geral pela direção central da multinacional, é o motivo mais frequentemente apontado para haver restrições de tradução e interpretação durante as reuniões e/ou de documentos produzidos no âmbito do CEE. 
É a preponderância do Inglês que explica que a formação para os representantes dos trabalhadores com assento nos CEEs seja quase exclusivamente centrada na aquisição de competências nessa língua. A este propósito, num estudo realizado por B. Tully (2004), onde foram conduzidas entrevistas com representantes dos trabalhadores de diversos países, foi frequentemente realçado o facto de os representantes dos países do Sul da Europa (Espanha, Portugal, Itália e Grécia) apresentarem menores competências linguísticas. A língua poderá, pois, para os países do Sul da Europa, funcionar como um fator de marginalização (Miller et al., 2000: 314; Stirling e Fitzgerald, 2001; Sirling e Tully, 2004; Costa e Araújo, 2009: 99).

\subsection{Peritos}

A Diretiva dos CEEs prevê a possibilidade de o Grupo Especial de Negociação (GEN) ser assistido por peritos à sua escolha para efeitos de negociação (o que pode incluir representantes das organizações de trabalhadores com competências reconhecidas ao nível comunitário). A figura dos peritos encontra-se igualmente presente para o acompanhamento das reuniões dos CEEs. A generalidade dos acordos analisados prevê, de facto, a possibilidade de os representantes dos trabalhadores convidarem um perito para assistir às reuniões (88 acordos em 111 analisados). Na grande maioria dos acordos o tipo de peritos não se encontra definido (67 acordos ou 43,2\%). Noutros casos é explicitamente prevista a possibilidade dos peritos poderem pertencer ou não a uma organização sindical (19 acordos), enquanto que apenas uma minoria de acordos (2) prevê que os peritos sejam exclusivamente membros de uma organização sindical (ver quadro 36 e gráfico 33).

Na prática dos CEEs, a presença dos peritos, apesar de prevista, é escassa. No caso dos representantes portugueses, a importância dos peritos é tanto mais significativa quanto se considera que a informação difundida em sede dos CEEs se reveste por vezes de um caráter excessivamente técnico. O papel que os CEEs reservam aos peritos é, pois, o 
de poderem funcionar como tradutores da informação (Costa e Araújo, 2009: 99). Porém, como foi referido no capítulo 1, o facto de a Diretiva 2009/38/CE (em vigor desde junho de 2011) prever que os sindicatos possam atuar como peritos poderá criar maiores possibilidades de tradução da informação mais difícil de decifrar por parte dos representantes de trabalhadores.

\section{QUADRO 36 - Peritos}

\begin{tabular}{|c|c|c|c|c|c|}
\cline { 2 - 6 } \multicolumn{1}{c|}{} & Indefinidos & $\begin{array}{c}\text { Representantes } \\
\text { de organizações } \\
\text { sindicais }\end{array}$ & $\begin{array}{c}\text { Indefinidos }+ \\
\text { Representantes de } \\
\text { organizações sindicais }\end{array}$ & $\begin{array}{c}\text { Não } \\
\text { referido }\end{array}$ & Total \\
\hline $\mathbf{N}$ & 67 & 2 & 19 & 23 & 111 \\
\hline$\%$ & $43,2 \%$ & $1,3 \%$ & $12,3 \%$ & $14,8 \%$ & $71,6 \%$ \\
\hline
\end{tabular}

Fonte: European Works Councils Database 2011

GRÁFICO 33

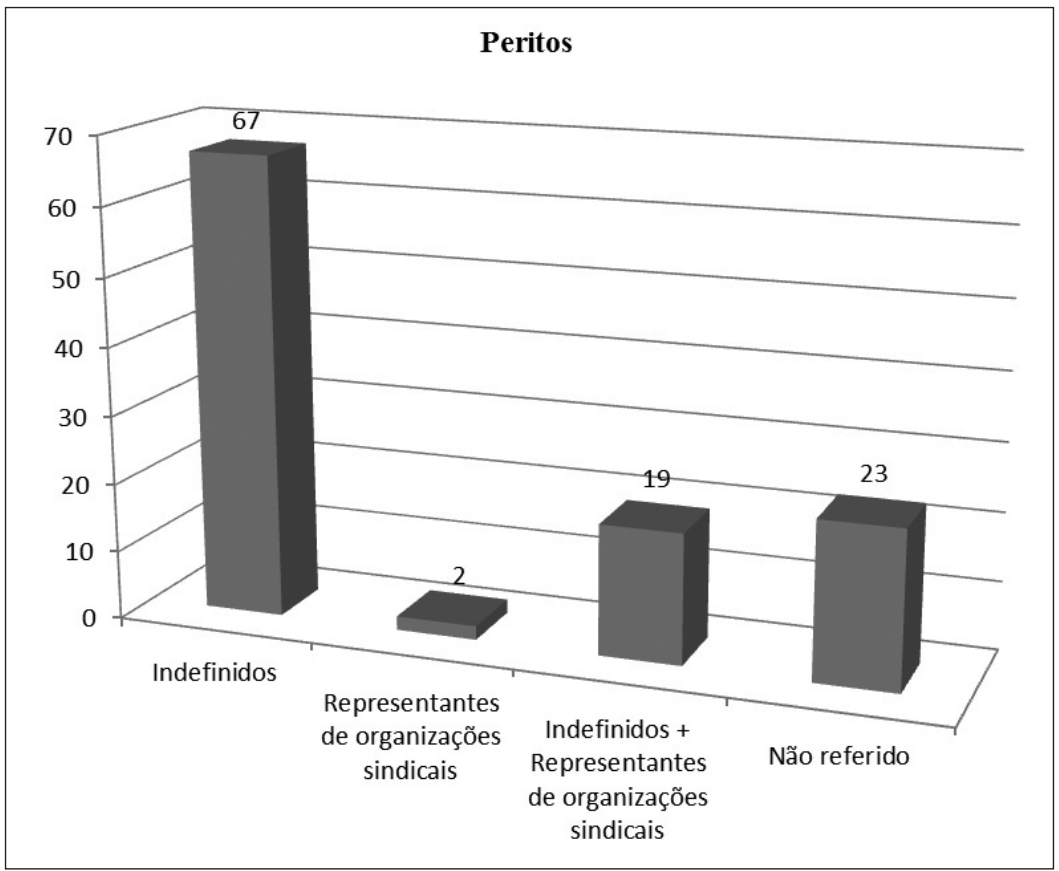

Fonte: European Works Councils Database 2011 
(Página deixada propositadamente em branco) 


\section{CA P ÍTULO 5}

\section{OS OLHARES DOS PROTAGONISTAS: REPRESENTANTES DE TRABALHADORES E ADMINISTRAÇ Õ E}

Este capítulo concede atenção à visão dos representantes portugueses em CEEs, bem como ao entendimento das administrações das empresas. Ainda assim, e uma vez que são sobretudo os representantes de trabalhadores que melhor sentem o "pulsar" dos CEEs, é a estes que é conferido maior destaque, nomeadamente pela análise de estudos de caso nos setores metalúrgico, químico e financeiro aqui privilegiados.

\section{A expressão dos representantes portugueses em CEEs}

Segundo a European Works Councils Database, o número de representantes portugueses eleitos em multinacionais a operar em Portugal nos setores aqui em análise era, em 2006, de 127 representantes distribuídos pelas multinacionais mais representadas em Portugal. Este cenário manteve-se sensivelmente inalterado em 2010. Assim, os países que mais multinacionais têm a operar em Portugal são aqueles que mais representantes elegeram: os EUA (27 representantes portugueses eleitos), a França (24), a Alemanha (18) e a Suíça (11). Portugal apenas figura na base de dados como país-sede de uma multinacional - o Grupo Banco Espírito Santo (BES) - cujos representantes no CEE são, à exceção de um, de nacionalidade portuguesa. 
QUADRO 37 - Representantes portugueses por país de sede das multinacionais

\begin{tabular}{|c|c|c|c|c|}
\hline \multicolumn{3}{|c|}{ Países da sede } & $\mathbf{N}$ & $\%$ \\
\hline \multirow{12}{*}{ Países do EEE } & \multirow{11}{*}{ UE-15 } & Alemanha & 18 & $14,17 \%$ \\
\hline & & Áustria & 1 & $0,79 \%$ \\
\hline & & Bélgica & 3 & $2,36 \%$ \\
\hline & & Dinamarca & 2 & $1,57 \%$ \\
\hline & & Espanha & 4 & $3,15 \%$ \\
\hline & & França & 24 & $18,90 \%$ \\
\hline & & Holanda & 4 & $3,15 \%$ \\
\hline & & Itália & 4 & $3,15 \%$ \\
\hline & & Portugal & 10 & $7,87 \%$ \\
\hline & & Reino-Unido & 9 & $7,09 \%$ \\
\hline & & Suécia & 4 & $3,15 \%$ \\
\hline & EFTA & Suíça & 11 & $8,66 \%$ \\
\hline \multirow{5}{*}{\multicolumn{2}{|c|}{ Países fora do EEE }} & Austrália & 1 & $0,79 \%$ \\
\hline & & Coreia do Sul & 1 & $0,79 \%$ \\
\hline & & Estados Unidos & 27 & $21,26 \%$ \\
\hline & & Japão & 3 & $2,36 \%$ \\
\hline & & Singapura & 1 & $0,79 \%$ \\
\hline \multicolumn{3}{|c|}{ Total } & 127 & $100,00 \%$ \\
\hline
\end{tabular}

Fonte: European Works Councils Database 2011

Em relação à distribuição desses representantes pelos três setores de atividade, em 2010 o setor metalúrgico elegeu 64 representantes $(48,5 \%)$, o setor químico 40 representantes $(30,3 \%)$ e o setor financeiro 28 representantes $(21,2 \%)$ (ver quadro 38$)$. Em termos de variação relativamente aos dados de 2006, constata-se um ligeiro aumento do número de representantes portugueses em 2010 (há mais 5 representantes, ou seja, 132), distribuídos do seguinte modo por setores de atividade: há mais 3 representantes no setor químico e mais 2 no setor metalúrgico, mantendo-se o número igual no setor financeiro. 
GRÁFICO 34

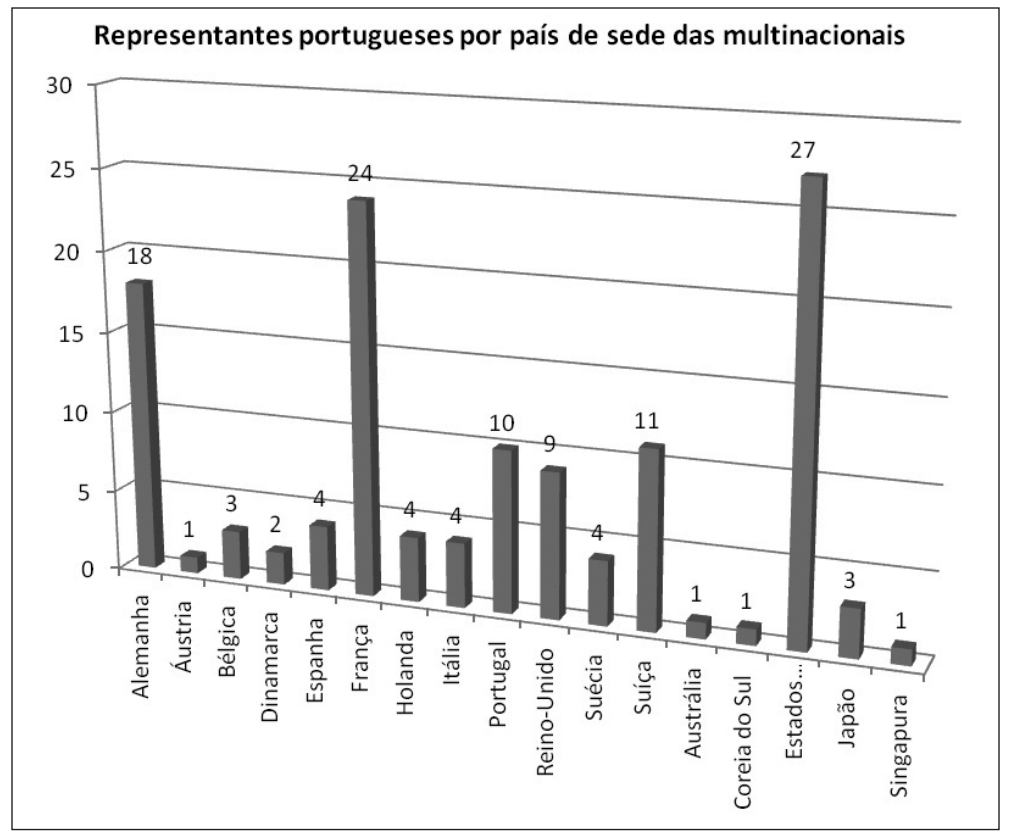

Fonte: European Works Councils Database 2011

QUADRO 38 - Representantes portugueses, por setor de atividade

\begin{tabular}{|l|c|c|c|}
\hline \multirow{2}{*}{ Setores de atividade } & \multicolumn{2}{|c|}{ Representantes portugueses } & \multirow{2}{*}{ Variação } \\
\cline { 2 - 4 } & $\mathbf{2 0 0 6}$ & $\mathbf{2 0 1 0}$ & \\
\hline Químico & 37 & 40 & 3 \\
\hline Metalúrgico & 62 & 64 & 2 \\
\hline Atividades financeiras & 28 & 28 & 0 \\
\hline
\end{tabular}

Fonte: European Works Councils Database 2011

\section{A visão dos representantes de trabalhadores}

Esta secção desdobra-se em dois momentos. No primeiro momento procede-se a um apanhado dos discursos (via entrevista) e opiniões (via 
GRÁFICO 35

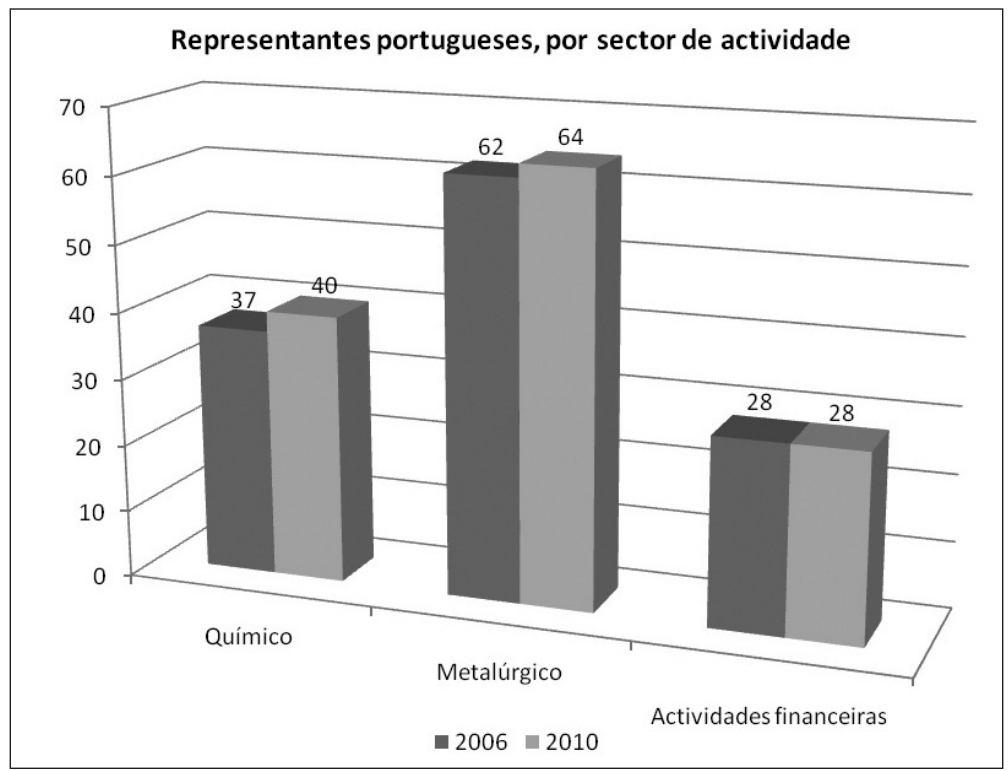

Fonte: European Works Councils Database 2011

inquérito) proferidos por representantes portugueses de trabalhadores em CEEs dos setores metalúrgico, químico e financeiro ao longo de 4 anos (o tempo que normalmente dura o mandato de um representante num CEE). Tal síntese analítica foi elaborada a partir da investigação de Costa e Araújo (2007b; 2009). Por meio dessa análise privilegiaram-se duas grandes áreas temáticas dos CEEs. Uma primeira, relativa ao processo de instituição dos CEEs, que abarca aspetos como a iniciativa para a constituição dos CEEs, a participação de representantes portugueses na negociação dos acordos, a avaliação do conteúdo dos acordos, etc. E uma segunda, que incide sobre o funcionamento dos CEEs, ou seja, a participação dos representantes portugueses nas reuniões dos CEEs (preparatórias, ordinárias, posteriores e extraordinárias), as questões e os problemas mais recorrentemente levantados pelos representantes, a avaliação dos resultados das reuniões (a quantidade, qualidade e oportunidade da informação, a consulta, e o princípio da confidencialidade), a restituição da informação e dos resultados das reuniões aos trabalhadores, 
e a consolidação de redes informais entre representantes dos trabalhadores para além dos espaços de reunião formal.

No segundo momento desta secção são analisados três estudos de caso reveladores de "boas práticas" dos CEEs. Antes disso, porém, procede-se a um enquadramento do papel setorial desempenhado pelas Federações Sindicais Europeias (FSEs), nos setores metalúrgico, químico e financeiro. O primeiro estudo de caso, do setor metalúrgico, é o do CEE da Volkswagen (tendo sido entrevistado o representante português da Autoeuropa). O segundo, do setor químico, dá voz ao representante português da Air Liquide. O terceiro, do setor financeiro, detém-se na experiência do CEE do Banco Espírito Santo. O aprofundamento destes estudos de caso permitiu, entre outros pontos, aflorar a discussão em redor dos seguintes pontos: o processo de revisão da diretiva e a nova Diretiva 2009/38/CE; o texto do acordo do CEE da multinacional em questão; o modo de funcionamento do CEE da multinacional do representante; os impactos da crise económica internacional nos CEEs; e a classificação da atuação dos CEEs, em geral, e do CEE a que o representante pertence, em particular.

\subsection{A instituição e funcionamento dos CEEs em Portugal}

Como foi sugerido anteriormente, os estudos de Costa (1996; 2004a; 2004 b) e de Costa e Araújo (2007b; 2009) foram os que em Portugal mais se detiveram na análise do papel dos CEEs. De modo a percebermos o impacto recente dos CEEs, torna-se, pois, obrigatório retomar algumas das conclusões a que tais estudos chegaram ${ }^{49}$.

\subsubsection{A instituição dos CEEs}

O processo de criação de um CEE e a consequente celebração de um acordo para the "dar vida" implica, como frisam Costa e Araújo (2009:

${ }^{49}$ Atente-se, para o efeito, na profunda análise desenvolvida por Costa e Araújo (2007b: 123-211; 2009: 116-171), da qual aqui recuperamos apenas alguns pontos. 
116-127), a recolha de informação sobre um conjunto útil de pontos: a iniciativa para a constituição dos CEEs; a participação de representantes portugueses na negociação dos acordos (desde logo por meio do seu envolvimento no Grupo Especial de Negociação/GEN); a seleção dos representantes; os processos de negociação dos acordos; a avaliação do conteúdo dos acordos; as questões que são objeto de informação e consulta; os processos de revisão dos acordos; ou ainda a duração dos mandatos dos CEEs. Importa, por isso, olhar brevemente para cada um deles.

i) A iniciativa para a constituição dos CEEs. É comum a iniciativa para a constituição dos CEEs ser conduzida pelos representantes dos trabalhadores das sedes das multinacionais. Esta situação explica-se não só por ser aí que está concentrada a maior parte da força de trabalho, como também pelo dinamismo (pressão) imprimido pelas organizações de trabalhadores (sobretudo sindicais) presentes nessas multinacionais da "casa-mãe". O "fator casa" (ao qual, aliás, já se fez referência no capítulo 2) revela-se, pois, fundamental para fomentar protagonismos distintos no seio dos CEEs. Daí que os CEEs sejam apresentados às filiais como factos consumados, podendo aí o processo ser desencadeado quer pelas organizações representativas de trabalhadores (ORTs), quer pelas próprias administrações. É, nesse sentido, mínima a iniciativa portuguesa no desencadeamento de processos negociais para a constituição de CEEs e são comuns as situações em que a tomada de conhecimento por parte dos representantes portugueses em CEEs da iniciativa do processo de constituição de CEE é feita após a assinatura do acordo e a constituição do CEE.

ii) O envolvimento dos representantes portugueses no GEN. Se é baixa a participação dos representantes portugueses na tomada da iniciativa para a constituição de CEEs, não surpreende que seja igualmente baixo o seu envolvimento no Grupo Especial de Negociação (GEN) ${ }^{50}$, tanto mais que quando participam os representantes portugueses tendem a aparecer

50 Recorde-se que, nos termos do artigo 5. ${ }^{\circ}$, n. ${ }^{\circ} 3$, da Diretiva 2009/38/CE "compete ao grupo especial de negociação fixar, com a direção central e mediante acordo escrito, o âmbito de ação, a composição, as atribuições e a duração do mandato do ou dos conselhos de empresa europeus ou as regras de execução de um procedimento de informação e consulta dos trabalhadores". 
em segundo plano. Quando confrontados ainda com o papel do GEN, os representantes portugueses tendem a realçar que seria importante fixar os termos dos acordos para além do texto formal da Diretiva, uma vez que as administrações tendem a procurar cumprir apenas os mínimos legalmente exigidos.

iii) A seleção dos representantes. Este ponto não pode ser visto em separado dos dois anteriores. O processo de seleção (eleição ou nomeação) dos representantes dos CEEs está longe de ser pacífico, pois a nomeação de representantes pelas administrações centrais ou mesmo locais e não por parte dos representantes dos trabalhadores subverte um processo que deveria ser democrático de raiz (Costa, 1996; 2004a: 233-236; 2004 b: 190-192; 2005: 631-632; 634-637; 2006b: 233-236; Costa e Araújo, 2006: 16; 2009: 124-126). Com efeito, esta é uma questão fundamental na medida em que parte da legitimidade dos representantes reside nos seus processos de eleição/nomeação. Na verdade, uma das preocupações que desde o início pairou sobre os CEEs foi o risco de serem controlados pelas administrações das empresas. Desse modo, estas poderiam utilizar os CEEs como forma de valorizar questões do interesse das empresas em vez de temas e questões sociais do interesse dos trabalhadores. Além disso, os CEEs podiam abrir a porta à construção de relações exclusivas com determinados representantes dos trabalhadores em detrimento do todo (Lucio e Weston, 2000: 208).

Face a este risco real, compreende-se melhor, por um lado, a crítica dos representantes portugueses quanto ao facto de os CEEs estarem a ser utilizados para fazer passar a visão da empresa como sendo a consensual e, por outro, que impere entre os membros dos CEEs um certo clima de desconfiança relativamente a "quem representa o quê". Nestes termos, poderá afirmar-se que a seleção de representantes para os CEEs está condicionada, em primeira mão, pela salvaguarda de um efetivo clima de confiança e reciprocidade entre as administrações e os representantes de trabalhadores.

Mas além disso, porém, é importante que o aprofundamento das relações entre os próprios representantes seja salvaguardado. Como afirma Costa (2004a: 233-238; 2004b: 190-194), de par com os obstáculos à seleção de representantes ditados pela "oposição patronal", não podem 
escamotear-se os obstáculos ditados pela "oposição sindical", pois nem sempre os representantes de trabalhadores se colocam de acordo eles próprios quanto ao representante a indicar. Ou seja, encontram-se situações (mesmo que de carácter pontual) de competição entre estruturas sindicais de sensibilidades político-ideológicas distintas, mas igualmente (ainda que raramente) de formas de competição intra-sindical pela indicação do representante dos trabalhadores, sendo que nestes casos estamos na presença de uma competição ditada pela relação tensa entre tendências sindicais distintas dentro de uma mesma estrutura sindical em que ambas estão filiadas (Costa e Araújo, 2009: 125). Este problema relativo às incompatibilidades entre os próprios representantes não está na "linha da frente" do processo de seleção de representantes. No entanto, ele sugere que é importante proceder igualmente a um aprofundamento das relações entre os representantes, ainda que estas relações estejam igualmente condicionadas por questões como a rotatividade dos membros dos CEEs, o número reduzido de reuniões ou as competências linguísticas e de comunicação envolvidas nos CEEs.

iv) A negociação dos acordos. A negociação dos acordos não é uma tarefa fácil e as expectativas dos representantes dos trabalhadores concentram-se sobretudo na possibilidade de os acordos "abrirem a porta" do diálogo para algo mais do que o estritamente estipulado pela Diretiva, ao passo que a vontade das administrações se limita ao cumprimento da Diretiva. O facto de decorrerem várias reuniões até à obtenção de um acordo - o tempo médio de duração do processo de negociação de um acordo é de cerca de dois anos - é em si mesmo uma expressão clara do "espírito de antagonismo" que, não raras vezes, se sobrepõe ao "espírito de colaboração" almejado pela Diretiva. Tendencialmente, sempre que um acordo se aproxima dos requisitos mínimos estabelecidos pela Diretiva ele tende a gerar menos atrito entre as administrações e os representantes de trabalhadores, podendo suceder o inverso (ou haver pretexto para maiores atritos) sempre que um acordo for de "banda larga".

v) O conteúdo dos acordos. Como se deu conta no capítulo 4, através do conteúdo dos acordos pode aferir-se se o processo negocial se limitou a alcançar os requisitos da Diretiva (o que efetivamente sucede 
na maior parte dos casos), ou se conseguiu ir para além disso. Ainda assim, porém, convirá notar que essa pode ser uma leitura de alguma forma enviesada devido a um generalizado e até surpreendente desconhecimento do conteúdo dos acordos patenteado pelos representantes. Um maior conhecimento do conteúdo dos acordos tende, todavia, a ser mais notório entre os representantes com maior experiência. Além disso, a aquisição das sucursais portuguesas por outras multinacionais, levando à reformulação dos acordos originais e a alterações na prática dos CEEs, é igualmente uma situação que permite aos representantes aferirem, por comparação, as perdas e ganhos no conteúdo dos acordos. Em todo o caso, os representantes tendem a desvalorizar os textos dos acordos pois consideram que é na prática, isto é, no modus operandi dos CEEs, que melhor se consegue aferir da eficácia dos acordos.

vi) As questões objeto de informação e consulta. Nos acordos de CEEs em que participam representantes portugueses nos setores em análise, as questões objeto de informação e consulta são convergentes com o espírito da Diretiva. Por um lado, porque salvaguardam que tais questões devem incidir exclusivamente sobre matérias transnacionais suscetíveis de afetar os interesses dos trabalhadores; por outro lado, porque referem explicitamente os assuntos que podem ser objeto de informação e consulta definidos pela Diretiva: a estrutura, situação económica e financeira da empresa; a evolução provável do emprego; os projetos, investimentos e estratégias da empresa; a introdução de novos métodos de trabalho, de produção e as novas tecnologias; as transferências de produção, fusões, reduções de pessoal, despedimentos coletivos e encerramentos; e a produção e vendas (produtividade e competitividade). Porém, os representantes portugueses em CEEs tendem a queixar-se: do excesso de informação técnica com que são confrontados; do défice de informação de nível nacional; de uma insuficiência generalizada de informação de qualidade; e do facto de as direções centrais procurarem, através dos CEEs, fazer passar a sua visão nas matérias que são objeto de informação e consulta.

vii) A revisão/reformulação dos acordos. Estranhamente (ou talvez nem tanto) são, por regra, escassas as opiniões de representantes portugueses de trabalhadores em CEEs sobre os processos de revisão e reformulação 
dos acordos, o que em parte se explica pelo já referido misto de desconhecimento/desinteresse generalizado dos conteúdos dos acordos. Isso mesmo se constata uma vez mais nos relatos dos três estudos de caso adiante analisados. A única convicção que se pode extrair da voz dos representantes em CEEs é a de que sempre que um acordo de CEE está em vias de ser revisto, o que se espera é que essa revisão se processe segundo uma orientação mais favorável aos trabalhadores, embora isso nem sempre pareça suceder.

viii) A Duração dos mandatos. Na generalidade, os representantes portugueses exercem mandatos de quatro anos. O cumprimento de mandatos longos representa, aliás, do ponto de vista dos representantes, a situação ideal na medida em que permite consolidar relações pessoais e adquirir a experiência necessária para o desempenho de funções num espaço diferente do espaço de intervenção local e nacional. Permite, por isso, consolidar as relações entre os próprios representantes, bem como o capital de confiança junto das administrações. O único senão (já aflorado acima a propósito da seleção dos representantes) parece residir num desfasamento que por vezes existe entre a duração dos mandatos dos CEEs e a duração dos mandatos nas organizações representativas dos trabalhadores (ORTs) nacionais. Aliás, nas empresas com sede em Portugal que ainda não constituíram CEEs, muito embora a rotatividade nas lideranças das ORTs nacionais seja sinónimo de democracia laboral, ela acaba por funcionar como um pretexto para excluir a questão dos CEEs da agenda de intervenção mais imediata (Costa e Araújo, 2007b: 24; 2008b). Para os representantes portugueses em CEEs, o ideal seria fazer

coincidir mandatos de CEEs com mandatos de ORTs nacionais, embora se constate que o timing das lutas nacionais (tidas como prioritárias) nem sempre é compatível com o timing da intervenção transnacional.

\subsubsection{O funcionamento dos CEEs}

De par com os aspetos processuais relativos à instituição dos CEEs, é crucial prestar atenção aos processos de funcionamento dos CEEs. Estes 
processos implicam, como se referiu acima: uma clarificação sobre a forma como a agenda das reuniões é definida; uma análise da participação dos representantes portugueses nas reuniões dos CEEs (preparatórias, ordinárias, posteriores e extraordinárias); uma identificação das questões e problemas mais frequentemente identificados pelos representantes; uma avaliação dos resultados das reuniões (a quantidade, qualidade e oportunidade da informação, a consulta, e o princípio da confidencialidade); um balanço relativo à devolução da informação e dos resultados das reuniões aos trabalhadores; e uma consolidação de redes informais entre representantes dos trabalhadores para além dos espaços de reunião formal (Costa e Araújo, 2009: 128-158).

i) Definição da agenda. A iniciativa de definir a agenda das reuniões dos CEEs cabe às administrações ou, em alternativa, resulta da articulação entre as administrações das empresas e os Conselhos Restritos (CRs). Isto significa que só esporadicamente as ORTs nacionais conseguem criar condições para influenciar as agendas das reuniões dos CEEs. Num estudo realizado em multinacionais do Reino Unido e da Alemanha com operações em ambos países, desde cedo as administrações procuraram manter um controlo apertado sobre a agenda dos CEEs com o propósito de controlarem o conteúdo da informação transnacional a circular nos CEEs (Weston e Lucio, 1997: 775). Ou seja, a definição da agenda de trabalho dos CEEs indica a presença de relações de poder que são tanto mais notórias quanto menor for a periodicidade das reuniões e limitada a participação dos representantes. Os CRs desempenham aqui um papel preponderante no sentido de interferir e negociar com a administração o modo de definição da agenda.

ii) As reuniões dos CEEs. As reuniões dos CEEs são um momento importante de contacto entre representantes de trabalhadores e entre estes e as administrações das multinacionais. Um olhar sobre tais reuniões permite avaliar a eficácia dos CEEs no cumprimento do seu duplo objetivo de informação e consulta. Além disso, a resposta à questão "para que servem os CEEs?", i.e., onde reside a sua dimensão funcional (Béthoux, 2004a) poderá ser melhor apreendida no contexto das interações propiciadas pelas reuniões. Por outro lado, é nas reuniões que os representantes se 
vão apercebendo do que efetivamente os CEEs "são capazes de fazer", ou seja, as suas possibilidades práticas (Didry et al., 2005), nomeadamente, por exemplo, quanto à capacidade dos CEEs permitirem ir além do âmbito da informação e consulta.

As reuniões que antecedem os encontros formais dos CEEs - reuniões preparatórias - são frequentes na maioria dos CEEs em que participam os representantes portugueses e são consideradas por estes como extremamente importantes. Estas reuniões servem para identificar um conjunto de problemas comuns aos trabalhadores e que devem ser colocados às administrações. Como tal, ajudam a definir uma agenda paralela à das administrações. Além disso, os representantes portugueses tendem ainda a maximizar as reuniões preparatórias dos CEEs para partilhar problemas locais, mesmo que tais problemas possam não ser abordados na reunião com a administração. Enquanto espaço de transmissão de conhecimentos e informações sobre a realidade das empresas locais, as reuniões preparatórias parecem ser, de resto, mais úteis do que as reuniões formais propriamente ditas. Nas reuniões preparatórias reforça-se o sentimento de pertença coletiva a um "corpo empresarial" comum (mesmo que a intensidade e o tipo de problemas seja variável), harmonizam-se posições entre os membros dos CEEs antes da reunião formal e ensaiam-se possíveis alianças para o caso de serem apresentados problemas que digam respeito não ao Grupo, mas a sucursais consideradas individualmente.

Por sua vez, as reuniões ordinárias tendem a ser vistas pelos representantes portugueses como menos importantes do que as reuniões preparatórias. Tais reuniões - que assinalam um momento de encontro formal entre a administração e os representantes dos trabalhadores suscitam pouca euforia por parte dos representantes, muito em especial quando o seu conteúdo é marcado pela discussão exclusiva de questões de âmbito transnacional e pela difusão de informação excessivamente generalista e técnica.

iii) Mecanismos de pertença que fazem a diferença: as sedes e os Conselhos Restritos. Embora os CEEs possam ser considerados como espaços de participação democrática ou "consensual", nos termos propostos por Moscovici e Doise (1991: 74 e ss.), a verdade é que estes são também 
espaços (como já antes se deixou antever) onde estão em jogo relações de poder (Stirling e Tully, 2004) e formas de participação desigual. Ora, o peso das sedes das multinacionais nas dinâmicas de participação nos CEEs e o papel dos CRs são fatores "desequilibradores" do envolvimento dos representantes de trabalhadores em CEEs.

Regra geral, os representantes dos trabalhadores das sedes das multinacionais dispõem de uma "vantagem caseira" (Lecher et al., 1999: 222) decorrente de um acesso privilegiado à informação. A presença desse "fator casa" não significa que os contactos, a troca de informações e as redes geradas pelos CEEs não constituam mais-valias para as filiais estrangeiras (Waddington, 2006c: 10). No entanto, não só os CEEs acolhem um maior número de representantes de trabalhadores provenientes da "casa mãe" da multinacional, como esses representantes recorrem frequentemente às estruturas nacionais de representação dos trabalhadores para obterem informação ou influenciarem decisões. Ou seja, não estão tão dependentes dos CEEs como estarão os representantes dos países das sucursais e possuem vantagens negociais assentes em relações já estabelecidas com as administrações. De certo modo, este argumento está próximo do de W. Streeck (1997; 1998), para quem os CEEs são uma extensão das relações laborais nacionais e tendem a secundarizar os representantes estrangeiros. Além disso, o facto de se continuar a verificar uma notória diferença percentual entre multinacionais abrangidas pela Diretiva e multinacionais com CEEs, tornaria defensável o argumento de que os representantes dos trabalhadores das sedes das multinacionais tendem a ser mais "resistentes" à criação de CEEs do que os trabalhadores das filiais.

O papel dos CRs, por seu lado, pode também fazer a diferença no que concerne à participação laboral nos CEEs. Os CRs estão previstos na esmagadora maioria dos acordos, sendo-lhe atribuída uma função que ultrapassa a coordenação e administração dos CEEs. Isto é, podem receber informação e reunir-se com a direção central regularmente e/ou em circunstâncias extraordinárias que afetem os interesses dos trabalhadores, mesmo que estas circunstâncias afetem apenas uma sucursal. O que significa que, enquanto "vértice estratégico" dos CEEs, podem também deslocar-se às filiais sempre que circunstâncias excecionais o exijam. 
Fazer parte de um CR significa, pois, assumir uma posição de destaque e algum poder. Note-se, por exemplo, que o processo de eleição de representantes para o $\mathrm{CR}$ significa o acesso a um órgão composto por um número limitado de lugares, decorrendo da participação no mesmo o acesso privilegiado (e mais rápido) a informação. Não surpreende, pois, que o CR seja o reflexo de tensões ideológicas, culturais ou linguísticas que caracterizam os CEEs e, como tal, de diferentes perceções sobre os seus objetivos e formas de ação. Entre os representantes portugueses de trabalhadores nos CEEs apenas um número limitado participa nos CRs (Costa a Araújo, 2009: 136), o que em parte se explica quer pela impossibilidade de exercerem funções de representação a tempo inteiro, quer pelas dificuldades no domínio de competências linguísticas.

Como demonstraram estudos de J. Waddington (2006a: 43; 2006c: 9), ao contrário dos restantes membros dos CEEs, os membros dos CRs consideram-se mais satisfeitos com a quantidade e qualidade da informação a que têm acesso, por sinal de modo privilegiado. Como assinalaram Costa e Araújo (2009: 137), para os representantes portugueses em CEEs a importância dos CRs reside sobretudo no acesso à informação, na possibilidade de reunirem mais vezes com as administrações, na possibilidade de intervirem em diversos momentos-chave do funcionamento dos CEEs (como a definição das agendas das reuniões, por exemplo), ou na possibilidade de sensibilizarem as administrações para questões locais. Este último aspeto será importante para compreender a lógica de participação dos representantes portugueses, pois trata-se de uma participação tendencialmente guiada por objetivos nacionais/locais.

iv) Balanço das reuniões dos CEEs. Na ótica dos representantes portugueses em CEEs dois aspetos limitam a possibilidade de melhorar o direito de informação e consulta: a periodicidade das reuniões, quando esta é apenas anual; e o tempo das reuniões, sobretudo quando estamos a falar de um único dia (Costa e Araújo, 2009: 138). A par do controlo sobre a agenda das reuniões, a periodicidade e duração das reuniões fazem parte da estratégia das multinacionais para limitar o conteúdo da informação transnacionalmente difundida (Weston e Lúcio, 1997). E mesmo não sendo uma preocupação exclusiva dos representantes portugueses, é 
apontada por eles como um aspeto a corrigir no desempenho dos CEEs. Com efeito, num inquérito a representantes de trabalhadores dinamarqueses constatou-se que o aumento do número e da duração das reuniões seria fundamental para melhorar o funcionamento dos CEEs (EIRR, 2000).

O balanço das reuniões dos CEEs pode fazer-se tendo em atenção os seguintes pontos relacionados com o funcionamento das reuniões: o teor da informação; o impacto da informação, da consulta e da capacidade de influência de decisões; a confidencialidade; o papel das redes informais; e a transmissão de informação aos trabalhadores por parte dos representantes em CEEs.

a) O teor da informação prende-se com a quantidade, qualidade e pertinência da informação. A posição dos representantes portugueses relativamente à informação é dual: por um lado, há uma avaliação positiva, na medida em que se faculta aos representantes uma visão global das atividades e dos problemas da multinacional que até aí era inacessível; por outro lado (e de modo mais generalizado), faz-se uma avaliação negativa devido ao carácter excessivamente técnico da informação prestada. Este excesso de informação técnica é uma das críticas mais frequentes dos representantes de trabalhadores portugueses em CEEs, na linha, aliás, de outros estudos (ETUC, UNICE/UEAPME, CEEP, 2005) que apontavam para a necessidade de compensar o excesso de carácter técnico com: a promoção de ações de formação; o recurso a peritos (Wills, 2001; Waddington e Kerckhofs, 2003); o reforço do apoio dos sindicatos/federações sindicais.

Assim sendo, informação veiculada em sede dos CEEs obriga por vezes os representantes dos trabalhadores a um esforço de "filtragem" da informação mais relevante, a qual, por sua vez, devem transmitir ao coletivo dos trabalhadores da empresa (filial) que representam. Este exercício torna-se tanto mais difícil quanto se sabe que a informação relativa às filiais nacionais tende a ser relegada para segundo plano quando comparada com a informação transnacional, cuja relevância é à partida menor para os representantes portugueses. Com efeito, uma vez que os representantes portugueses se guiam sobretudo por objetivos locais, isso significa que tendem a olhar para os CEEs como fontes de informação 
secundária (Waddington, 2006c: 9), nomeadamente em comparação com os mecanismos nacionais de acesso à informação.

b) O impacto da informação, da consulta e da capacidade de influência de decisões é igualmente decisivo para uma perceção do funcionamento dos CEEs. Ora, os representantes portugueses em CEEs referem que em apenas 1/3 das situações as informações são transmitidas e discutidas previamente à tomada de decisões (Costa e Araújo, 2009: 143). Por outro lado, o espaço reservado para a consulta prévia é bastante escasso e os representantes que referem o défice de oportunidade da informação são igualmente aqueles que expressam uma opinião negativa relativamente à oportunidade da consulta. Em regra, as decisões das administrações já estão tomadas quando são comunicadas aos representantes dos trabalhadores, ainda que estes possam dar a sua opinião e manifestar-se contra tais decisões ou em favor da sua reconsideração. Assim sendo, uma efetiva capacidade de influenciar decisões depende do acesso à informação, da qualidade da informação, da oportunidade da informação, dos modos de exploração da informação por parte dos representantes e da conciliação de interesses entre administrações e representantes dos trabalhadores em torno de determinadas matérias. Na maioria dos CEEs com representantes portugueses foi reduzida a capacidade de influência das decisões por parte dos CEEs, confirmando resultados de outros estudos. 51

c) O princípio da confidencialidade consta de quase $90 \%$ dos acordos de CEEs onde participam representantes de trabalhadores portugueses (Costa e Araújo, 2009: 147). Sobre este princípio, os representantes portugueses tendem a expressar dois tipos de opiniões. Por um lado, e em nome da ideia de que "o segredo é a alma do negócio", reconhecem que são veiculadas nos CEEs informações sobre negociações, estratégias, formas de planeamento, investimentos, etc., das multinacionais que importa preservar como forma de salvaguardar os interesses quer das multinacionais, quer inclusive dos trabalhadores. Porém, em simultâneo,

${ }^{51}$ Com efeito, num inquérito aplicado em 2005 aos representantes em CEEs de multinacionais de 196 países (com uma taxa de resposta de 19,8\%), J. Waddington (2005; 2006a; $2006 \mathrm{~b} ; 2006 \mathrm{c})$ verificou que apenas $2 \%$ afirmaram que os CEEs dispunham de alguma possibilidade de influenciar decisões. 
lamenta-se que as administrações, "à boleia” de uma certa legitimidade associada à confidencialidade, aproveitem para omitir informação em demasia aos trabalhadores. Daí que estes tendam também a considerar o recurso à confidencialidade como um bloqueio ao acesso a informação de qualidade, isto é, relevante para o seu futuro.

A questão da confidencialidade poderá mesmo suscitar uma tensão identitária entre a fidelidade que os representantes devem aos trabalhadores que representam e o compromisso de confidencialidade que têm para com a administração. No caso de terem acesso a informações prejudiciais para os trabalhadores nacionais (reestruturações, perdas de produção, encerramentos, deslocalizações, etc.) deverão manter a confidencialidade? A nosso ver, em contexto de crise económica a opção de não divulgação de informação por parte dos representantes dos trabalhadores só será legítima se visar ganhar tempo para definir uma estratégia favorável aos trabalhadores.

d) O papel das redes informais põe também à prova a eficácia do funcionamento dos CEEs. Entre os representantes portugueses têm sido escassos os encontros além das reuniões formais (Costa e Araújo, 2009: 151). Não só são escassas as redes de contactos entre representantes de diferentes setores de atividade (o que causa menor surpresa, ainda que um setor onde se alcançaram "boas práticas" devesse servir de referência para outros), como, mais surpreendente, entre representantes do mesmo setor de atividade. Porventura só quando organizações sindicais decidem organizar eventos sobre o tema é que pode haver pretexto para reunir representantes. Ora, uma forma de compensar a escassez generalizada de reuniões formais de CEEs, ou mesmo de encontros entre representantes convocados por organizações sindicais, são as redes e os contactos informais. É nessas redes e contactos que os trabalhadores por vezes acedem a informações que não obteriam pela via formal, permitindo-lhe assim dispor de alguma vantagem relativa perante as administrações locais. É através do intercâmbio de informação que os representantes tomam conhecimento das diferenças entre sucursais e que procuram, muitas vezes por meio de alianças estratégicas, acederem a direitos, regalias, benefícios, etc. 
Apostar nos contactos informais implica, claro está, a superação de divergências ideológicas entre representantes ou de diferenças culturais e linguísticas, o que nem sempre é fácil quando existem dificuldades em dominar uma língua franca (como o inglês). Daí que também seja frequente os representantes portugueses terem maior apetência para, nos contactos informais (onde nem sempre dispõem de um tradutor), procurarem aproximar-se mais de outros representantes com os quais possuem maiores afinidades linguísticas, como os espanhóis ou mesmo os italianos.

e) Um último balanço decorrente do funcionamento das reuniões dos CEEs prende-se com a transmissão de informação aos trabalhadores por parte dos representantes em CEEs. Embora não seja uniforme, este processo concretiza-se normalmente por meio da realização de plenários de trabalhadores ou de comunicados, mas podem igualmente ser utilizados o correio eletrónico, a intranet ou mesmo a produção de boletins informativos. Convirá ter em conta que este processo de transmissão de informação aos trabalhadores é decisivo para que se perceba que papel é efetivamente desempenhado pelos CEEs e que expectativas se podem construir a seu respeito. Ainda assim, os representantes de trabalhadores não têm propriamente um interesse na realização de plenários que tenham como único objetivo a devolução da informação recebida nos CEEs, o que faz supor que a informação colhida nos CEEs não é, regra geral, suficientemente importante para justificar a mobilização dos trabalhadores. Porém, em momentos de crise iminente é redobrado o interesse por parte dos trabalhadores em conhecer o teor da informação veiculada nos CEEs.

\subsection{CEEs nos setores metalúrgico, químico e financeiro: as Federações Sindicais Europeias e os estudos de caso (Volkswagen, Air Liquide, BES)}

Neste espaço concede-se uma atenção central aos setores aqui em análise. Por um lado, dá-se conta do contributo transnacional das Federações Sindicais Europeias (FSEs) na dinamização da atividade dos CEEs. Ainda que os CEEs não sejam instituições sindicais, o contributo de 
organizações como as FSEs para o seu funcionamento é decisivo quer para o reforço da representatividade dos CEEs, quer para uma monitorização do seu funcionamento, nomeadamente sempre que os interesses laborais não forem respeitados (Costa, 2004a: 233-236; 2004b: 190-192). Por outro lado, analisam-se em detalhe 3 CEEs: o primeiro no setor metalúrgico (CEE do Grupo Volkswagen); o segundo no setor químico (CEE do Grupo Air Liquide); e o terceiro no setor financeiro (CEE do Grupo Banco Espírito Santo).

\subsubsection{0 papel das Federações Sindicais Europeias}

O comportamento setorial dos CEEs recebe um contributo decisivo das FSEs. Como ficou dito no capítulo 1, na nova Diretiva 2009/38/CE esse papel das FSEs é objeto de um acrescido reconhecimento que, no futuro, pode potenciar uma europeização setorial do sindicalismo e, consequentemente, conferir uma maior dinâmica aos CEEs. Com efeito, as FSEs deverão ser notificadas da composição do Grupo Especial de Negociação (GEN) e do início das negociações (artigo 5. ${ }^{\circ}$, §2c da Diretiva 2009/38/CE). Desta forma, os sindicatos poderão monitorizar até que ponto as estruturas de representação dos trabalhadores existentes são respeitadas na eleição ou designação dos membros do GEN, de acordo com as regras e procedimentos nacionais em vigor, tal como determina o artigo $5 .^{\circ}, \S 2 \mathrm{a}$ da Diretiva 2009/38/CE.

Não faremos aqui uma análise do modo como todas as FSEs têm vindo a debater e a incorporar a problemática dos CEE nas suas atividades ${ }^{52}$. Daremos apenas algum destaque às FSEs que desenvolvem atividades nos setores aqui em análise: setor metalúrgico - Federação Europeia de Metalúrgicos/European Metalworkers' Federation (EMF, http://www.emf-fem.org/) -; setor químico - Federação Europeia dos Trabalhadores das

52 Uma análise desse tipo implicaria um estudo à parte, obrigaria a olhar para as especificidades de cada setor e a enquadrar com maior detalhe o papel dos CEEs em diferentes domínios. 
Minas, Química e Energia/European Mine, Chemical and Energy Workers Federation (EMCEF, http://www.emcef.org/) -; e setor financeiro - Rede Sindical Internacional-Europa/ Union Network International-Europa, UNI-Europa, http://www.uniglobalunion.org/Apps/iportal.nsf/pages/ reg_20081016_gca9En). Para o efeito, apoiamo-nos na reflexão empreendida por Waddington (2011: 28-54) ${ }^{53}$. Para este estudioso dos CEEs, vários argumentos são legítimos para conferir atenção especial ao papel das FSEs na relação com o tema dos CEEs.

Em primeiro lugar, porque é importante notar que as análises desenvolvidas sobre os pioneiros acordos de CEEs e os estudos de caso entretanto realizados identificaram o "setor" como sendo um fator chave nos resultados. Ao nível europeu, a maior parte das FSEs encontram-se organizadas numa base industrial ou setorial e podem, deste modo, ser vistas como elementos com influência setorial. Ao longo de toda a década de noventa, muitas das recomendações emanadas da Confederação Europeia de Sindicatos (CES) insistiam na necessidade de se prestar uma maior atenção aos CEEs. A Resolução Towards a European System of Industrial Relations, adotada no IX Congresso da CES (Helsínquia, 1999), colocava nas FSEs a responsabilidade da coordenação das atividades europeias associadas aos CEEs bem como ao seu desenvolvimento e objetivos de longo prazo.

Em segundo lugar, porque o artigo $5 .^{\circ}$ da Diretiva (tanto da Diretiva 94/45/CE, como da Diretiva 2009/38/CE em vigor) sustenta que o procedimento para a criação de um CEE pode ser desencadeado ou por iniciativa da administração central ou "mediante pedido escrito de, no mínimo, 100 trabalhadores, ou dos seus representantes, provenientes de pelo menos duas empresas ou estabelecimentos situados em pelo menos dois Estados-membros diferentes". O que significa que existe aqui, portanto, o ónus do lado dos trabalhadores para iniciar o processo de criação de um CEE. Independentemente do estatuto do representante dos trabalhadores no local de trabalho, é pouco provável que ele/ela tenha a informação, os

53 Ver igualmente Pulignano (2007) ou Waddington (2006b), neste caso com um enfoque no setor químico em geral e a partir de uma investigação junto da EMCEF. 
recursos ou os conhecimentos necessários para contactar os seus colegas noutra parte qualquer da Europa. Assim sendo, os sindicatos estarão mais capacitados, quer em termos de recursos, quer em termos de contactos internacionais, para aproximar pessoas e colocá-las em rede. ${ }^{54}$ As organizações sindicais poderão, desta forma, estar envolvidas desde o início no processo de constituição dos CEEs. Waddington, no entanto, deixa no ar a seguinte questão: será que os sindicatos contactados por membros que desejem estabelecer um CEE serão capazes de articular as suas atividades com as das FSE?

O terceiro argumento para analisar os CEEs tendo por referência as FSEs deriva do debate entre os que são críticos da Diretiva e os que veem potencialidades nos CEEs. O papel e a capacidade das organizações sindicais estão no centro deste debate. Para os críticos da Diretiva, as organizações sindicais não são capazes de impedir o isolamento dos representantes dos CEEs daqueles que eles representam e de outros representantes dos CEEs. Além disso, foram incapazes de alterar os recursos materiais e políticos para um nível apropriado dentro das organizações sindicais europeias e são incapazes de impedir que os CEEs se tornem extensões dos sistemas e instituições nacionais. Por sua vez, para os defensores da Diretiva, devem ser realçadas as capacidades que os CEEs têm para potenciar as redes de contactos internacionais e as novas formas de solidariedade transnacional, os amplos efeitos ao nível da formação, etc. Seja como for, tanto os críticos como aqueles que veem potencial na Diretiva colocam a atividade sindical, em particular a capacidade para articular a atuação do sindicalismo em diferentes níveis, no centro das suas reflexões sobre o futuro dos CEEs.

Em quarto lugar, existe uma evidência generalizada que mostra que nas situações em que as organizações sindicais não estiveram envolvidas

\footnotetext{
54 Esta afirmação é legítima mas tem de quer ponderada. Na verdade, como veremos nos estudos de caso (VW, Air Liquide e BES), apenas num deles (BES) o papel dos sindicatos foi realçado, ainda que, em termos europeus (e também em Portugal) a tendência dominante seja valorizar a atuação dos sindicatos. Isto, sem prejuízo de, no caso português, ser igualmente patente um relativo descomprometimento das principais confederações sindicais portuguesas relativamente aos CEEs (Costa, 2004a; 2004b).
} 
ou foram excluídas dos CEEs a qualidade da participação foi colocada em questão, por exemplo, através da imposição por parte dos empregadores de indivíduos da sua confiança nos CEEs. Além desta constatação, de resto bem notória no caso português (Costa, 1996; 2004a; 2004b; Costa e Araújo, 2009), muitos estudos já efetuados mostram que sem o envolvimento dos sindicatos alguns CEEs não são capazes de cumprir o princípio básico para o qual foram criados: o da participação transnacional dos trabalhadores.

Uma quinta justificação para ligar as FSEs aos CEEs prende-se, segundo Waddington, com a natureza da europeização sindical e a articulação das atividades dos CEEs. A relação entre as FSEs e os CEEs encerra em si o potencial para ser um elemento central da europeização dos sindicatos. Para que essa relação tenha algum significado é necessário que haja articulação vertical entre as FSEs e sindicatos filiados e, por outro lado, articulação horizontal entre as FSEs e os diferentes CEEs. A forma como estas relações/articulações se têm vindo a fazer ao longo dos últimos anos nas três principais FSEs teve impacto nos próprios CEEs e no seu desenvolvimento.

Nos setores aqui em análise, o papel de revelo vai, como se referiu acima, para a EMF, a EMCEF e a UNI-Europa, sendo que as duas últimas FSEs (EMCEF e Uni-Europa) passaram por processos de fusão que deram origem às atuais designações. A EMF é responsável por 31,4\% das multinacionais que estão dentro do âmbito da Diretiva, a EMCEF por 19,1\% e a UNI-Europa por $23,3 \%$. No total, as três FSEs são responsáveis por $73,8 \%$ de todas as multinacionais abrangidas pela Diretiva dos CEEs. A taxa de criação de CEEs para as três FSEs é de 44,1\%, 45,5\% e 35,3\%, respetivamente (Waddington, 2011: 30). A variação da taxa tem a ver, entre outros fatores, com a atividade das próprias FSEs, com a taxa de sindicalização, com ações das administrações, com as características estruturais das próprias multinacionais, com a capacidade dos sindicatos filiados nas FSEs para mobilizarem recursos tendentes à criação dos CEEs, entre outros aspetos.

O envolvimento das três FSEs na temática dos CEEs tem vindo a evoluir também à medida que estes foram sendo criados. Com a exceção 
da UNI-Europa Graphical, cada uma das três FSEs estudadas viram-se inicialmente ultrapassadas pelo número de acordos de CEEs concluídos durante o período 1994-96 associados ao artigo $13 .^{\circ}$ da Diretiva 54/45/ CE. Como consequência, o grau de controlo exercido pelas FSEs sobre os termos dos acordos concluídos e sobre as práticas dos representantes foi, na maioria dos casos, muito limitado. Apesar de as três FSEs terem desenvolvido procedimentos para regular os acordos e as práticas, em muitos casos existem diferenças substanciais entre as intenções processuais e a sua implementação. Cada uma das três FSEs procurou controlar melhor a atividade dos CEEs ao definir termos "aceitáveis" nos acordos e nas práticas e introduzindo procedimentos mais rigorosos para poderem controlar melhor a assinatura de novos acordos ou a renegociação de outros. A este respeito existem diferenças substanciais entre as três Federações. A EMF desenvolveu um sistema chamado "descentralização regulada”, segundo o qual foi imposta alguma autoridade central processual, dando origem a determinadas formas de desenvolvimento dos CEEs. Por seu lado, a política da EMCEF é descentralizada mas com poucas tentativas de articulação da atividade dos CEEs com a desta FSE e com uma relativa autonomia das organizações sindicais filiadas. A UNI-Europa tem vindo a implementar políticas semelhantes às adotadas pela EMF dentro de cada uma das suas diferentes secções. No entanto, não existe um comité central que atue de forma a obrigar a seguir um enquadramento político único. No caso das três FSEs, parece evidente, na opinião de Waddington (2011: 32), que as variações das suas políticas produzem um impacto significativo na prática dos CEEs.

Mesmo com diferenças temporais entre si, as três FSEs introduziram instituições e procedimentos similares como forma de articular as atividades dos CEEs. Por exemplo, introduziram mecanismos para melhorar os padrões dos acordos de CEEs e as suas práticas tendo por base a atividade dos coordenadores, em geral escolhidos no país sede da multinacional. Um conjunto de alvos negociais, que se tornaram mais exigentes à medida que os procedimentos se repetiam, acompanhou o desenvolvimento institucional e processual de cada FSE. Inicialmente, em grande medida os alvos negociais refletiam os termos das "disposições supletivas" da 
Diretiva. À medida que se completava a primeira ronda de negociações para o estabelecimento dos acordos, os alvos negociais iam mudando, muitas vezes ultrapassando o estipulado nessas "disposições supletivas". Ou seja, os procedimentos e as etapas institucionais foram melhorando e os alvos negociais foram aumentando à medida que a experiência dos CEEs foi crescendo.

O âmbito da autoridade reguladora exercida pelas FSEs foi igualmente sendo mais apertado ao longo do tempo, à medida que as instituições e procedimentos se foram adaptando e os recursos políticos disponibilizados permitiam a regulamentação pelas FSEs. Neste quadro, no entanto, a extensão da autoridade reguladora e o carácter da descentralização variam muito. A EMF funciona na base de um único Company Policy Commitee que é responsável pela política dos CEEs de todos os setores que compõem esta Federação. A introdução de linhas de orientação obrigatórias, um sistema onde os peritos sindicais são sujeitos à aprovação do Company Policy Commitee, e a definição de coordenadores atuando dentro da EMF, contribuíram para o elevado grau de regulação central sobre as atividades dos CEEs. Apesar de a EMF definir as suas linhas de orientação como "obrigatórias", é óbvio que isso nem sempre assim funciona na prática. Na UNI-Europa, os setoral steering committees conferiram alguma regulação central, mas não tanta como a que se verifica na EMF, uma vez que cada steering committee setorial tem autonomia para implementar políticas diferentes. Contrariamente, a EMCEF escolheu exercer uma autoridade central ténue sobre os CEEs até 2004 e, depois disso, desenvolveu-se muito lentamente. Diferenças políticas entre sindicatos filiados, a sucessiva mudança do pessoal responsável pelos CEEs, e a autonomia tradicionalmente detida pelos works councillors e representantes locais dos principais sindicatos filiados contribuíram para restringir o grau de autoridade central. Como consequência, a política dos CEEs na EMCEF está, nesta FSE, em larga medida dependente das atividades dos seus sindicatos filiados.

O papel destas e de outras FSEs é, pois, fundamental para dar vida aos CEEs. E talvez seja expectável que as FSEs consigam tirar ainda melhor proveito das suas atuações no domínio dos CEEs se, entre elas, houver 
também esforços de cooperação inter-setorial. Isto é, se à articulação dentro de um mesmo setor (envolvendo centenas ou mesmo milhares de multinacionais) se acrescentarem estratégias de articulação entre FSEs de setores distintos, até porque muitos problemas de diferentes empresas e setores são comuns (Costa, 2004a; 2004b). Em 30.06.2010 e 1.07.2010, a EMCEF (na sua $8^{a}$ Assembleia Geral) apresentou mesmo uma moção onde se equaciona a possibilidade de fusão ou criação de uma nova FSE, reunindo a EMCEF, a EMF e a ETUF: TLC (European Trade Union Federation: Textiles, Clothin and Leather/Federação Europeia dos Sindicatos Têxteis, Vestuário e Peles). Embora algumas das razões de fundo invocadas para lançar esse debate em torno de uma possível agregação inter-setorial sejam a globalização, a internacionalização financeira, a desindustrialização, a crise e a fusão de federações nacionais, é um facto que de processos deste tipo decorrem igualmente importantes implicações para o perfil dos CEEs e para a formação de uma identidade sindical europeia mais coesa em seu redor.

\subsubsection{O CEE do Grupo VW55}

O setor metalúrgico é o que regista maior presença de multinacionais em condições de constituir CEEs e também o setor com maior número de CEEs efetivamente constituídos. O CEE do Grupo VW constitui uma referência incontornável que vale a pena analisar sob vários pontos de vista: a cultura de parceria social que lhe está na base; a dimensão do Grupo VW, a filial portuguesa e o papel que a comissão de trabalhadores (CT) desempenha na concretização de uma cultura de diálogo social com a administração; os sinais de democracia laboral propiciados pela "vida interna" do CEE; a maximização de outros mecanismos de diálogo social

55 Como foi assinalado anteriormente, o retrado deste CEE apoiou-se numa entrevista de fundo com o representante de trabalhadores da Autoeuropa (fábrica da VW em Portugal) em Outubro de 2010. Nela se confirmaram e atualizaram informações prestadas pelo mesmo representante noutra entrevista realizada quatro anos antes (em 2006) e disponível em Costa e Araújo (2007b: 343-353). 
em resultado da prática do $\mathrm{CEE}$; o processo de revisão da diretiva e a nova Diretiva 2009/38/CE.

\subsubsection{Uma cultura de parceria social como ponto de partida}

O Grupo VW conhece uma tradição de negociação que começou em "casa", sob forte inspiração da "cultura-mãe" alemã, há pelo menos quatro décadas. Trata-se, pois, de uma cultura de proteção dos trabalhadores que já existia antes da criação do CEE e que se manteve após o seu surgimento em 1992. Aliás, como salientava o representante dos trabalhadores do CEE do Grupo VW, desde que o CEE foi criado nunca encerrou nenhuma fábrica da VW. Mas para ajudar a explicar essa situação, é igualmente necessário levar em linha de conta o papel histórico da "lei VW"56: o conselho fiscal - composto por 20 elementos, 10 representantes de trabalhadores e 10 accionistas - é determinante no sentido de evitar o encerramento de fábricas, pois para encerrar uma fábrica do grupo são precisos pelo menos $2 / 3$ dos votos:

O Grupo funciona da seguinte maneira: se decidirem encerrar uma empresa ou decidirem colocar produtos em qualquer lado são necessários à volta de $75 \%$ de votos. O conselho fiscal, como se chama, tem 20 elementos, sendo que 10 são representantes dos trabalhadores e 10 dos accionistas. O que significa que para ter $75 \%$ de votos têm que 15 pessoas votar naquela sala a favor de qualquer uma dessas decisões. Para encerrar uma empresa era necessário que pelo menos cinco representantes dos trabalhadores tivessem dito que sim (...). Se fosse com base na lei alemã, para a dimensão da VW, teria que ter três pessoas no conselho fiscal. Mas a Lei VW é uma coisa completamente diferente da Lei alemã no que diz respeito à co-gestão, porque vem de uma história que é a bistória que se segue ao fim da Segunda Guerra Mundial" (representante português no CEE do Grupo VW, 18.10.2010).

56 Para um enquadramento da "lei VW", cf. Chora (2008) e ainda o documento "Informações de fundo sobre a Lei VW", disponível em http://www.oskovo.cz/Ext/VW/vwp_07por.pdf. 
Ora, a constituição do CEE do Grupo VW, em 1992, por iniciativa do sindicato alemão IG-Metall (Industriegewerkschaft Metall), veio corroborar precisamente esse espírito de diálogo reinante no seio da VW. Como de resto foi assinalado no capítulo 2, os representantes da administração da VW consideram o CEE como um instrumento útil para envolver os representantes dos trabalhadores nas políticas do Grupo. Por sua vez, os representantes dos trabalhadores consideram que o CEE do Grupo VW consegue criar coesão interna e se baseia numa visão estratégica que pode tornar-se um fator de influência na expansão transnacional do Grupo.

\subsubsection{O Grupo VW, a Autoeuropa e o papel de interlocução da CT}

Além do suporte histórico conferido pela "lei VW" e da forte tradição de organização laboral (sindical e não só), a pujança do Grupo VW explica em parte o desempenho do CEE do Grupo VW. Os números de 2010 e 2011 relativos à produção de veículos, volume de vendas e lucros líquidos dão testemunho disso. Em 2010, o grupo aumentou o número de veículos entregues aos clientes para 7.203 milhões (2009: 6.336 milhões), correspondendo a uma quota de $11,4 \%$ do mercado mundial de automóveis de passageiros. Por sua vez, em 2011 o número de veículos entregues superou a barreira dos 8 milhões (8.265 milhões), ou seja, mais $15,5 \%$ do que em 2010 e correspondendo a uma quota de 12,3\% do mercado mundial de automóveis de passageiros. Quanto à preponderância do universo VW e seu volume de vendas, constata-se que, em 2010, na Europa Ocidental, um em cada cinco carros novos (21\%) provém do Grupo VW. Nesse ano, as vendas do grupo atingiram os 126,9 mil milhões de euros (em 2009 foram 105,2 mil milhões). Em 2011, por sua vez, no mesmo espaço geográfico, um em cada cinco carros novos (23\%) provém do Grupo VW, tendo nesse ano as vendas do grupo chegado aos 159 mil milhões de euros. Por fim, se em 2010 o lucro líquido do Grupo VW, retirados os impostos, ascendeu a 7,2 mil milhões de euros (em 2009 foi de 0,9 mil milhões), em 2011 o cenário foi ainda mais favorável, com o Grupo a 
duplicar os seus lucros face ao ano anterior, ou seja, alcançando lucros de 15,8 mil milhões de euros. ${ }^{57}$

O Grupo é formado por 12 marcas de 7 países europeus: Volkswagen Passenger Cars, Audi, SEAT, ŠKODA, Bentley, Bugatti, Lamborghini, Porsche, Ducati, Volkswagen Commercial Vehicles, Scania e MAN. 58 O Grupo opera em 100 fábricas (incluindo a fábrica de Silao, no México, cuja produção se iniciou em janeiro de 2013), distribuídas por 19 países europeus e mais 7 países nas Américas, Ásia e África. Em todo o mundo, em cada dia da semana, cerca de 550.000 funcionários produzem cerca de 37.500 veículos, ou estão envolvidos nos serviços relativos ao veículo ou outras áreas de negócios. O Grupo VW vende os seus veículos em 153 países ${ }^{59}$.

Instalada em Portugal há mais de duas décadas, primeiro como joint-venture composta pelos Grupos Ford e VW, e a partir de 1999 apenas pelo Grupo VW, a fábrica portuguesa da VW (Autoeuropa) tem vindo a evidenciar desempenhos muito favoráveis, que por sinal são reconhecidos mutuamente pela administração e trabalhadores e esse facto, vale a pena assinalá-lo, contribui também de forma decisiva para valorizar o papel do CEE. Em 2009, por exemplo, a Autoeuropa foi a segunda maior exportadora nacional, evidenciando um peso de $0,8 \%$ no PIB $^{60}$, ao passo que em 2010 a filial portuguesa da VW atingiu a produção mais elevada desde 2003, chegando aos 101.284 veículos e ultrapassando a barreira das 100 mil unidades que tinha previsto produzir. Segundo o diretor-geral da fábrica da Volkswagen, António de Melo Pires, o aumento de 18\% face a 2009

57 http://www.volkswagenag.com/content/vwcorp/content/en/the_group.html, acedido em 20.06.2013.

58 Em 2009, a VW e a Porsche anunciaram a intenção de fusão de modo a tornar-se o maior Grupo europeu. Porém, tal fusão foi sendo condicionada por entraves fiscais e legais. Para se tornar a maior do mundo em 2018, superando a Toyota com 10 milhões de veículos vendidos anualmente, a VW teria de incorporar a Porsche totalmente. Em junho de 2013, a Porsche detinha ainda $50,7 \%$ das ações da VW (http://www.jornaldenegocios.pt/empresas/ detalhe/familia_porsche_piech_recompra_10_das_accoes_da_empresa_a_qatar_holding.html), informação consultada em 20.06.2013.

59 http://www.volkswagenag.com/content/vwcorp/content/en/the_group.html, acedido em 20.06.2013.

$60 \mathrm{http}: / / \mathrm{www}$.ionline.pt/conteudo/67370-fabrica-em-palmela-da-autoeuropa-foi-segun da-maior-exportadora-em-2009 
deveu-se em grande parte à retoma dos mercados no final do ano ${ }^{61}$. Por outro lado ainda, mesmo tendo em conta que em 2012, em resultado da situação económica nos mercados europeus e da continuidade da recessão em 2013 em países como França, Itália ou Espanha (pois 98,9\% da produção é exportada), a Autoeuropa tenha decidido adotar uma gestão de produção semana a semana (segundo dava conta, em fevereiro de 2012, o diretor-geral da Autoeuropa), não pode ainda deixar de se assinalar o notável desempenho alcançado em 2011, por sinal o melhor da última década: uma produção de 133.100 veículos (mais 31\% do que em 2010) e um volume de negócios que subiu 36\%.62

Numa fábrica onde são produzidos os conhecidos modelos Sharan, EOS, Scirocco e Alhambra (sendo este da marca SEAT), segundo o site oficial do Grupo VW a força de trabalho em 31.12.2012 era composta por 3.640 empregados. Ora, no modo como são articulados os interesses dos trabalhadores com a administração, a comissão de trabalhadores (CT) joga um papel central, nomeadamente em detrimento da presença sindical (na Autoeuropa o n. ${ }^{\circ}$ de sindicalizados ronda os 45\%). Diferentemente da CT, a atitude sindical face ao papel de informação e consulta de trabalhadores de âmbito transnacional que é desempenhado pelo CEE parece suscitar ainda desconfianças:

Enquanto os nossos sindicatos encararem os CEEs como encaram, como uma coisa da social-democracia, de políticas de direita, que não é para levar a sério, que é uma coisa para embalar meninos, que ali não se resolve nada, que os CEEs são de carácter puramente consultivo, que a luta deve ser sempre interna, que devemos olhar muito para as questões nacionais e deixar lá essas coisas, etc., enquanto isso suceder e não houver predisposição para participar é difícil incorporar o sindicato (Representante português no CEE do Grupo VW, 18.10.2010).

61 http://jornal.publico.pt/noticia/13-01-2011/autoeuropa-atinge-producao-mais-altadesde-2003-e-quer-transporte-mais-eficiente-21008051.htm

62 http://jornal.publico.pt/noticia/02-02-2012/autoeuropa-cautelosa-na-gestao-em-2012apos-melhor-ano-da-decada-23906410.htm, acedido em 2.02.2012. 
Não surpreende, pois, que a CT seja interlocutora preferencial da administração da Autoeuropa. Aliás, são várias as experiências de negociação, desde logo quando em novembro de 2003 a CT acordou com a administração o princípio da flexibilidade do horário de trabalho sem perda de salário, salvaguardando o emprego de 895 dos 3200 trabalhadores da fábrica portuguesa ${ }^{63}$. Além desse acordo de efeitos "vitalícios"64, vale ainda a pena recordar, de um ponto de vista pecuniário, o acordo que, em outubro de 2010, a CT acordou com a administração no sentido de garantir aumentos salariais de 3,9\% para 2011. Este exemplo, de fazer inveja a uma economia portuguesa em recessão, beneficiava claramente da influência do "ciclo produtivo" alemão, em contraciclo face ao português. Ou seja, num contexto de crescimento não só da VW como da expectativa de crescimento da própria Autoeuropa, a ideia de aumentos salariais, mesmo que possa ser sinónimo de "ilha isolada", não só era vista como desejável mas também como natural:

A nossa expectativa, tal como consta da introdução do nosso Caderno Reivindicativo, é a de que a Autoeuropa, apesar de toda a crise que atravessou no ano passado, apesar da acentuada baixa de produção, cerca de 10 ou 12 mil carros a menos, ainda teve um lucro líquido de 14 milhões de euros. Não há qualquer razão para não haver aumento salarial este ano. Porque ela teve lucro o ano passado, e porque ela vai ter lucro este ano fruto do aumento da produção, pois vamos passar de 84.000, para 101.000. Portanto, não há razão para não haver aumentos, apesar do défice enorme do Estado (Representante português no CEE do Grupo VW, 18.10.2010).

63 Em termos práticos, e para fazer face à quebra da produção de veículos, a CT e a administração da empresa acordaram que entre outubro de 2003 e outubro de 2005, os trabalhadores da empresa efetuariam 22 dias de paragem. Esses 22 dias não trabalháveis 12 dias anuais entre outubro de 2003 e setembro de 2004 e 10 dias anuais entre outubro de 2004 e outubro de 2005 - funcionariam como regra vitalícia e corresponderiam a um não aumento salarial durante dois anos (Costa, 2004c).

64 "Isso continua, esse acordo existe, é eterno entre aspas...dos vinte e dois dias não trabalháveis, este ano (2010) já utilizámos quatro ou cinco, portanto, em janeiro iremos receber o que falta para os vinte e dois, há-de ser pago num pagamento único" (Representante português no CEE do Grupo VW, 18.10.2010). 
Na ótica da CT da Autoeuropa e do seu representante, esta expectativa de aumento da capacidade produtiva punha igualmente em realce o subaproveitamento da fábrica portuguesa, razão pela qual esta questão devia ser transmitida no próprio CEE:

Ora, praticamente uma das fábricas que está com baixa capacidade ou que está com baixo nível de aproveitamento é a Autoeuropa. Está com 55\% de aproveitamento. Tem 45\% de capacidade disponível. Não é de mão de obra, é de capacidade instalada disponível para receber um novo produto. Daí nós irmos agora, quando for ao Comité Europeu, levar não só a questão do investimento na pintura como também a questão da necessidade de um novo produto para rentabilizar o investimento que está aqui feito. Nós temos capacidade para fazer 200 mil carros por ano, vamos fazer 101 mil este ano. Quer dizer, já são mais 15\% ou 20\%. (Representante português no CEE do Grupo VW, 18.10.2010).

Como já antes se referiu, a demonstração da capacidade produtiva da Autoeuropa foi, na verdade, uma realidade em 2011. E tal foi reconhecido pela administração que, em março de 2012, em face dos 133.000 carros produzidos em 2011, atribuiu a cada um dos 3.620 trabalhadores um prémio anual de 938 euros. Mas em paralelo com essa demonstração da capacidade produtiva da Autoeuropa, está o trabalho que a CT tem vindo a desenvolver junto da administração e por meio do CEE, no sentido de fundamentar a opção pela flexibilidade laboral, um pouco na linha do mencionado acordo dos down-days celebrado no final de 2003. Apesar de longa, a seguinte citação é elucidativa da predisposição para abraçar práticas de trabalho flexíveis, mas de uma flexibilidade efetivamente benéfica para os trabalhadores, sendo que o papel da CT e do CEE têm sido importante nesse sentido:

Se amanhã a Autoeuropa alegar que aqui é mais caro fazer um carro do que em Espanha ou na Alemanha tem razão. Porque a logística é muito cara. É preciso arranjar métodos de ultrapassar isso. Nós aqui temo-lo conseguido. E este é um exemplo que a própria $V W$, e agora quando cá estiverem esses indivíduos [do conselho fiscal da VW] reconbeceram isso. Durante muito tempo ouviu-se falar que era preciso haver um banco de horas ao sábado 
na Autoeuropa, era uma obsessão que as direções anteriores tinham. Neste momento nós conseguimos falar com o novo diretor, conseguimos falar com essas dez pessoas [do conselbo fiscal] que aqui vieram e provámos que somos a fábrica mais flexível da VW na Europa. E quase que uma das mais flexíveis no mundo. E fiz-lhes uma apresentação onde lhes provei isso. A gente aqui muda uma equipa completa de turno a seguir à sua folga. O trabalhador que trabalha esta semana folga sábado e domingo, está no turno da manhã. Mas se for preciso vir no turno da manhã seguinte eles vêm. Isto não acontece em mais lado nenhum na Europa. E provámos-lhes isto, demos-lhes os dados todos. E isso foi decisivo ao ponto de neste momento eles dizerem, "eh pá, a gente não quer falar mais em sábados, banco de boras".

A própria administração já o reconbeceu, ao dizer: "vamo-nos calar com isso". Porque o custo do sábado a 100\% em Portugal é muito mais barato que o custo do sábado a 50\% na Alemanha. Portanto, não faz sentido estar a falar nisso... neste momento, há um acordo tácito entre a comissão de trabalhadores, o seu representante no Comité Europeu, e a própria administração em vender a flexibilidade que temos. Durante o tempo de um ex-administrador que aqui tivemos, durante outro tempo vendia-se aquela tentava-se passar a ideia de que não tínhamos. No fundo, a tentar que o comité europeu pressionasse a comissão de trabalhadores da Autoeuropa a aceitar a flexibilidade aos sábados, coisa que eles nunca fizeram. Nunca! E felizmente que o não fizeram, em boa hora que não o fizeram.

É claro que se a gente seguisse à risca aquilo que está no contrato coletivo de trabalho (que agora caducou fruto daquelas decisões da caducidade...), se seguíssemos à risca aquelas funções, isso significava que este indivíduo só leva a chave daqui para ali, isso é verdade, ninguém conseguia trabalhar neste país, ou então tinha que se recorrer ao despedimento. Por exemplo, quando a gente aqui decidiu há anos automatizar toda a área do body, que era o underbody, em que havia peças que pesavam quinze quilos, em que os trabalhadores passavam-lhes 300 peças em cada turno pelas mãos, trezentas vezes quinze quilos... então robotizámos tudo isso e dissemos "bom, mas nenhum trabalhador vai despedido, eles são soldadores por pontos, é verdade, estão aí, mas agora vão trabalhar na montagem final, vão montar peças e trabalhar com os mecânicos e o que for preciso...". E receberam formação para isso, como é 
evidente. Qual era a solução se seguíssemos à risca: "bom, o gajo é soldador por pontos, não há trabalho para isso, é despedido". Quer dizer, essa é a solução tradicional em Portugal.

Ora, aqui houve grande recetividade por parte dos trabalhadores para se incorporar essa lógica flexível. O que os trabalbadores quiseram foi ficar na empresa e usufruir dos salários, usufruir das regalias sociais, usufruir de uma série de coisas (Representante português no CEE do Grupo VW, 18.10.2010).

Por outro lado ainda, é constatável na Autoeuropa uma "descentralização" da cultura de diálogo da "casa-mãe", tanto mais que as reuniões (e, portanto, o diálogo e comunicação que lhes subjaz) entre representantes de trabalhadores e administração da empresa tendem a aumentar nos "períodos de negociação":

Agora, na fase negocial, reunimos às terças e quintas-feiras com a administração. Nas outras fases é todas as segundas-feiras, o normal é todas as segundas. Na fase negocial reunimos às segundas, terças e quintas. Às terças e quintas é negociação, ao passo que às segundas são os problemas gerais (Representante português no CEE do Grupo VW, 18.10.2010).

E ao mesmo tempo, para além da facilidade de contactos entre capital e trabalho na empresa portuguesa, a própria CT faz o trajeto "ascendente", isto é, dirige-se à sede, ao vértice estratégico (que é a administração da VW), sempre que considera necessário e, portanto, sempre que alguma questão não fica totalmente resolvida no shop floor da fábrica portuguesa. Não causa, pois, qualquer estranheza que seja a coordenação da CT a indicar (nomear) o representante para ocupar o lugar de representante dos trabalhadores no CEE, não obstante não existir uma coincidência entre a duração dos mandatos do CEE e os mandatos da CT.

\subsubsection{Um CEE sintonizado com a ideia de democracia laboral}

Pelo que ficou dito nas subsecções anteriores (cultura de diálogo da casa-mãe e da filial portuguesa, bem como o contexto favorável do Grupo 
VW e da Autoeuropa em termos de produtividade e de resultados líquidos) não surpreende que o CEE do Grupo VW apresente sinais evidentes de democracia laboral em ação. Em nosso entender, é defensável o argumento de que o favorecimento de condições de democracia laboral nas empresas e, portanto, de formas de partição negociada entre as partes que compõem uma relação laboral varia na razão direta do aumento da produtividade. No caso do CEE do Grupo VW, o seu funcionamento faz-se, pois, em nome de uma ideia e de uma prática de democracia laboral em sentido pleno.

Ora, o primeiro testemunho da existência de democracia no local de trabalho prende-se com o facto de os problemas na empresa serem escassos ou quase inexistentes. O que se explica pela situação de desafogo financeiro da VW: "Neste momento eu não lhe sei indicar qualquer problema porque a VW está de vento em popa, como sabemos. Portanto, não há problemas, neste momento" (Representante português no CEE do Grupo VW, 18.10.2010). Mas é importante destacar a preocupação que o CEE tem para com os eventuais problemas de cada filial. Ou seja, ao contrário do que é a prática em muitos CEEs, não é preciso que um problema ocorra em dois Estados do Espaço Económico Europeu (EEE) para que ele possa ser resolvido, o que significa que o CEE permite que se trate primeiro dos problemas mais graves e só depois dos problemas comuns a várias filiais do Grupo VW.

No nosso caso (CEE do Grupo VW) cada um levanta o seu problema, levantamos esses problemas entre nós. Depois é feita uma lista de prioridades para, no outro dia, levarmos à administração. Portanto, no dia da reunião com a administração nós escolhemos entre nós, comissões de trabalhadores, o que é que vamos lá levar. Até pode dar-se o caso de cada fábrica levar lá um problema, mas temos é que selecionar a prioridade nos problemas (Representante português no CEE do Grupo VW, 18.10.2010).

Ainda assim, mesmo sendo escassos, os principais problemas que foram levados ao CEE ou que tiveram no CEE um importante foco de intermediação e que se encontram hoje praticamente resolvidos ou em 
vias de o ser são os seguintes ${ }^{65}$ : o encerramento do posto médico ao fim de semana; a destituição de um team líder por ser membro da CT; a não automatização das cabines de pintura; o conhecimento dos destinos dos investimentos futuros da empresa; a substituição de um administrador que prejudicava as relações com os trabalhadores. Vale a pena atentar com um pouco mais de detalhe nalguns deles:

Por exemplo, a questão da destituição de um team líder por ser membro da CT foi "julgada” em sede de CEE e resolvida nesse areópago:

Nós tentámos aqui reunir-nos com os recursos humanos, mas não conseguimos. Eu fui lá, apresentei isso no relatório. Foi-me perguntado se eu queria colocar isso, no outro dia, ao diretor mundial de recursos humanos, visto que o nosso diretor, no caso era uma senhora, estava na sala também presente nesse dia. E depois a gente senta-se assim, normalmente, é o diretor de recursos bumanos aí, portanto é uma mesa assim em forma de " $U$ " e o representante dos trabalhadores aqui, e depois no topo da mesa fica o diretor de recursos bumanos... E eu disse, "sim senhor, pois claro que queria levantar o problema". Fo i tomado nota e no outro dia o presidente do comité mundial, a primeira coisa que fez, depois do diretor dos recursos humanos ter feito toda a exposição como eu disse, sobre os recursos humanos existentes, sobre previsões, alterações, não sei quê, é aberto o debate. (...). Eu coloquei uma questão e gerou-se logo ali uma discussão entre o diretor dos recursos humanos e eu...(...) o entendimento dos recursos humanos a favor da saída do líder de equipa devia-se ao facto de a comissão de trabalhadores the ocupar muito tempo e então tinha que deixar de ser líder de equipa. Isso gerou ali uma certa discussão entre nós até que às tantas o senhor virou-se e disse assim: "eu já entendi tudo, não é preciso estarem a discutir mais, eu já percebi tudo". Ficou assim. Sei que depois fomos almoçar, passado meia hora de ter acabado o almoço tocou o telefone e era o meu colega aqui a dizer: "chamaram-me agora, já sou team líder outra

65 A prova de que o CEE do Grupo VW funciona de modo eficaz reside no facto de termos tido de fazer um apanhado dos (escassos) problemas reportados pelo mesmo representante de trabalhadores do CEE em dois momentos diferentes em que foi entrevistado (novembro de 2006 e outubro de 2010), ou seja, abrangendo um período longo de identificação de possíveis problemas. 
vez. Diz que estiveram a pensar melhor, não sabiam o que é que... foi um erro e tal". É claro que foi ordem de lá porque, assim que eu cheguei aqui a senhora disse-me "você fez uma coisa que não devia ter feito e tal, ali à frente dos meus colegas". Eu disse-lhe. "desculpe lá mas eu avisei-a aqui que se não resolvêssemos aqui antes de apanhar o avião que apresentava o problema lá" (Representante português no CEE do Grupo VW, 17.11.2006).

Este exemplo mostra como os CEEs são órgãos onde podem exercer-se importantes formas de pressão secundária (à escala transnacional) sempre que à escala micro (nacional, da empresa) os problemas não são devidamente solucionados.

Outro dos problemas mencionados prende-se com o reforço dos padrões de saúde e qualidade no trabalho, reclamando-se para o efeito uma automatização das cabines de pintura. E, note-se, trata-se de uma questão levada não apenas ao CEE, como inclusive levantada no Conselho de Empresa Mundial (CEM) do Grupo VW:

Vamos levantar agora no Comité Mundial a questão da necessidade de aprovação, agora no próximo plano de investimentos, de automatização das cabines de pintura na nossa fábrica, aqui na Autoeuropa, visto que é uma coisa que não é automática. Ainda temos lá pessoal com escafandros a pintar, é semi-automático. Digamos que um terço é automático, o resto ainda não é. Portanto, vamos levantar essa questão porque é muito importante em termos de saúde das pessoas, em termos de qualidade até do trabalho (Representante português no CEE do Grupo VW, 18.10.2010).

Ainda outro problema que merece a pena ser aqui referenciado, embora já pertença ao passado, prendeu-se com o facto de um ex-administrador da Autoeuropa ter criado um mau ambiente de trabalho no seio dos trabalhadores e de ter tido a pretensão, ao arrepio da tradição da VW, de acabar com as reuniões de comunicação e de impor formas de tratamento autoritário para com os trabalhadores portugueses. Ora, uma vez mais aqui o recurso ao CEE foi a via transnacional para a resolução de um problema nacional: 
Fui eu que levei a questão ao Conselho de Empresa. Disse concretamente estas palavras: "eu estive na Escola da IG-Metall em Berlim durante duas semanas numa ação de formação sobre sistemas de produção $V W$ em que englobava os intervalos, portanto, englobava tudo e agora o senhor [nome do ex-administrador] chega à Autoeuropa e diz que quer acabar com os intervalos e dá uma ordem mesmo para acabar com os intervalos e, portanto, para acabar com as reuniões de comunicação, principalmente”. Portanto, ele entendia que os intervalos podiam ser arredados, efetivamente não acabavam, mas que as reuniões de comunicação tinham que acabar. Ele achava que faziam parte do tempo de trabalho. Por ser tempo de trabalbo, ele dizia que isso na Polónia fazia-se fora do horário normal de trabalho e, portanto, aqui também deviam ser feitas as reuniões fora do horário normal de trabalbo. Isso gerou alguma polémica, como é evidente, aqui dentro da empresa. E depois era a maneira como ele tratava as pessoas... quer dizer, ele tinha um tratamento colonialista, no melhor sentido da palavra: "Eu sou alemão, eu sei, vocês são portugueses, não percebem nada disto".

Ora, a substituição dele tem que ver com essa questão, claramente. Ele, no último dia, teve aqui uma conversa comigo e foi imediatamente para a Alemanha. Passadas duas horas dele chegar eu recebo um fax a dizer que ele tinha apresentado o pedido de demissão. É claro que eu sabia que não era nada disso do que se estava a passar. Depois tive o cuidado de falar pessoalmente com ele... Mas, quer dizer, isto mostra como o Comité Europeu pode funcionar em situações deste género (Representante português no CEE do Grupo VW, 18.10.2010).

Apesar de escassos, os problemas existentes tendem, como se disse, a procurar ser solucionados, desde logo, em primeira-mão, à escala nacional e envolvendo os representantes dos trabalhadores em processos de tomada de decisão numa fase preliminar. Aliás, o próprio CEE procura afirmar-se como órgão conciliador entre a sede e a filial da multinacional: "Por exemplo, se nós fizermos uma greve aqui a primeira coisa que eles nos dizem é para antes de entrarem em greve comuniquem-nos, para ver o que é que nós podemos fazer cá" (Representante português no CEE do Grupo VW, 17.11.2006). 
Um outro sinal instigador de confiança e democracia propiciada pelo CEE prende-se como o facto de a informação e a consulta (fruto do tal envolvimento precoce dos trabalhadores) serem vistas como suficientes: "há respostas claras a todas as perguntas que se possam fazer" (Representante português no CEE do Grupo VW, 17.11.2006) e não há sectarismos nas posições dos diferentes representantes (portanto, não há riscos de contribuições desiguais), ainda que os trabalhadores da sede possam ter acesso mais fácil (rápido) a informações, como reflexo do já antes designado efeito de "fator casa", que em parte se explica pela influência do regime de relações laborais do país europeu de onde a empresa é originária.

O formato das reuniões do CEE do Grupo VW e a sua preparação prévia são, na verdade, aspetos que concorrem para um esclarecimento ponderado e atempado do tipo de problemas que possam surgir e, consequentemente, para um bom funcionamento do CEE. No que diz respeito à agenda das reuniões, importa dizer que não obstante a organização das reuniões do CEE permitir um conhecimento atempado das questões a discutir, uma vez que os relatórios são previamente enviados por e-mail em três línguas distintas (inglês, alemão e língua do representante) a todos os representantes, isso não passa propriamente de um procedimento formal. Com efeito, a agenda dos problemas é flexível, o que significa que não há uma agenda prévia, fixa ou imposta pela administração pois isso é definido em reunião entre as próprias organizações representativas de trabalhadores (CTs, sindicatos ou outras), facto que é revelador de uma certa informalização na definição da própria agenda:

Os relatórios são previamente divulgados por e-mail entre nós todos. Há aqui um manual em três línguas: inglês, alemão e a língua original. Todos nós conhecemos mais ou menos os relatórios todos quando lá vamos mas isso não impede que se leia o relatório na íntegra. O que acontece às vezes no comité europeu em que são menos dias, normalmente são dois dias apenas, é que se pede um resumo do relatório. Portanto, os relatórios são traduzidos, quando lá chegamos temos os relatórios traduzidos na língua nacional e depois pede-se que se faça um resumo de modo que todos já conhecemos a situação concreta 
em cada fábrica. E depois é só uma questão de agendar o que é que vamos discutir no outro dia... Mas não há agenda no nosso caso. A agenda somos nós que a decidimos na reunião com as comissões de trabalhadores. A agenda que vamos apresentar à direção amanhã somos nós que decidimos hoje aqui reunidos (...). É para isso que serve a reunião antes, a reunião antes só entre as comissões de trabalhadores serve exatamente para isso. Serve para que nós nos inteiremos das prioridades que temos, da situação social, económica em que se encontra cada localização, não só da empresa como do país. E depois dos problemas concretos da empresa, ou dos problemas concretos com que os trabalhadores se defrontam na empresa e que poderão necessitar de uma intervenção a nível superior (Representante português no CEE do Grupo VW, 18.10.2010).

O testemunho anterior ajuda-nos igualmente a perceber qual o formato das reuniões dos CEEs e o modo como se criam condições de aproximação entre representantes de trabalhadores, numa base que começa por ser essencialmente informal e que só depois se torna mais formal à medida que vai deixando de ser "entre iguais" (ainda que, mesmo neste caso, se conserve o clima de diálogo). Com efeito, as reuniões do CEE ocupam sempre mais do que um dia. O primeiro dia é para os representantes dos trabalhadores discutirem entre si o tipo de problemas que têm, o que sucede sem a presença de elementos da direção do grupo. Os dias seguintes já contam com os diretores dos recursos humanos e elementos da direção do grupo. O segundo dia está normalmente reservado ao encontro entre trabalhadores e diretores de recursos humanos, ao passo que o terceiro dia fica então reservado para a reunião entre representantes de trabalhadores e a direção do Grupo VW.

A importância dos contactos informais e a noção de solidariedade entendida como sinónimo de reciprocidade são mais dois sinais do bom funcionamento do CEE do Grupo VW. Por um lado, a questão dos contactos informais é importante na medida em que, como foi dito anteriormente, tais contactos permitem por vezes o acesso a informações que nem sempre são veiculadas pela via formal (i.e., no espaço formal da reunião) ou mesmo a resolução de problemas, pois a colocação de problemas 
de modo mais informal pode tornar mais célere a sua resolução. E essa prática ou conjunto de procedimentos informais tanto podem ocorrer à margem de reuniões formais do CEE como inclusive de reuniões de âmbito ainda mais alargado (internacional). Ainda que mais distante no tempo, o testemunho seguinte evidencia como o representante português dos trabalhadores (simultaneamente membro do CEE do Grupo VW e do Conselho de Empresa Mundial) resolveu um problema ao jantar com diretores de recursos humanos:

Normalmente quando o problema é muito bicudo o que acontece é que, quando se vai para o jantar (e já aconteceu comigo), na mesa estão os nomes das pessoas e o meu nome estava ao lado do tradutor. E por acaso foi bom porque resolveu um problema complicado que a gente tinha aqui: foi o caso concreto de eles não terem pago um prémio de, na altura, cerca de 800 euros aos trabalhadores que tinham aderido à greve, pois diziam que tinham ultrapassado o número de dias permitidos para poderem faltar. Nós entendíamos que a greve era uma suspensão do contrato de trabalbo, como está na lei, e não uma falta. Isso gerou uma polémica enorme cá. Gerou uma polémica enorme depois com o diretor de recursos humanos mundial e isso foi resolvido à mesa. $\mathrm{Na}$ mesa estava eu, o diretor de recursos humanos de cá, o diretor mundial de recursos humanos, o presidente do comité mundial de trabalhadores. Eram estes que estavam na mesa mais os tradutores. Ninguém comeu naquela mesa, estou desconfiado que ninguém comeu naquela mesa. Por acaso até foi aqui em Lisboa, na Cruz Vermelha Portuguesa... Ninguém comeu naquela mesa porque a discussão foi tal que depois... mas também ali ninguém me disse nada. A única coisa que o presidente mundial de recursos humanos me disse foi que ia ver melhor isso e depois davam-nos uma resposta. Até hoje não recebi resposta nenhuma. A resposta que recebi foi que... "estivemos a pensar melhor, o prémio vai ser pago a toda a gente a título excecional". Não saiu comunicado, já depois de terem dito que não iam pagar às pessoas, disseram então que a título excecional iam pagar (Representante português no CEE do Grupo VW, 17.11.2006). 
Além deste exemplo ilustrativo de que há problemas que se resolvem ao jantar e depois já não regressam à mesa das negociações mais formais, há também informações que podem ser veiculadas pela via informal e que dizem respeito ao setor metalúrgico (automobilístico) coberto pela VW e não apenas ao universo VW. Foi o que sucedeu com a informação transmitida via CEE do Grupo VW de que a empresa Opel em Portugal iria ser encerrada. O curioso, neste caso, é que foi o próprio presidente da VW que o transmitiu na reunião do CEE, confirmando alguns rumores que já circulavam nesse sentido:

O próprio presidente da VW foi dizê-lo num comité. Ele disse que a Opel estava a atravessar uma grande crise e que as previsões eram encerrar uma fábrica em Inglaterra, o que acabou por acontecer, e encerrar fábricas na Península Ibérica, nomeadamente em Portugal (...). Em 2002 eu fui avisado de que aquilo ia fechar. E o Representante da GM aqui dizia-me: "eh pá, isso não pode ser, ainda esta semana vim de lá...". E eu dizia-lhe: "pois, tu vieste de lá mas eu vim agora de Inglaterra, onde foi realizado o Comité Europeu da VW, e foi a própria direção da VW que disse que a Ford ia fechar algumas empresas na Europa e que a Opel também e uma delas era Portugal. Portanto, mete-te a pau com isso!" (Representante português no CEE do Grupo VW, 17.11.2006 e 18.10.2010).

Este exemplo é revelador, por um lado, de que os CEEs estão longe de ser devidamente informados com antecedência do que se pode passar com a força de trabalho no seu todo (designadamente com as filiais das multinacionais), pois ao mesmo tempo que, com muita antecedência, uma informação que era veiculada no CEE do Grupo VW, essa mesma informação era omitida (não divulgada) no seio do CEE da GM. Por outro lado, o exemplo mostra como, a partir da transmissão de informações (mesmo que pela via informal) entre CEEs - por meio de uma cultura de comunicação intra-setorial - se podem gerar formas de solidariedade entre trabalhadores (ou pelo menos de "avisos à tripulação”), ainda que, como se compreende, essas formas de solidariedade sejam sobretudo recorrentes entre os trabalhadores de diferentes filais 
da mesma multinacional, mesmo em casos de desfecho desfavorável para os trabalhadores ${ }^{66}$.

Ainda que por vezes seja mais desejada do que praticada, a questão da solidariedade é, de facto, central no funcionamento de qualquer CEE e não apenas no CEE do Grupo VW. Trata-se, no caso deste, de uma solidariedade internacionalista ${ }^{67}$ e não apenas europeia, direccionada para evitar o encerramento de fábricas. E é nesse sentido que conta com o apoio do conselho fiscal da VW e do peso que nele têm (como se disse anteriormente) os representantes dos trabalhadores. Uma vez que não há notícias de encerramentos (ou pelo menos não estão na ordem do dia) e, portanto, também de ações de greve que visem travá-los, a solidariedade que dá segurança é a que decorre do voto de confiança transmitido pelos representantes de trabalhadores que ocupam um lugar no conselho fiscal, como sucedeu no passado no Brasil e na Argentina:

A solidariedade é reciprocidade... No caso do Brasil, por exemplo, durante os três primeiros anos foi discutido ali se os representantes no conselho fiscal (que é igual para o mundo inteiro) iam ou não apoiar o envio de 400 milhões de euros para salvar a VW no Brasil da falência. E foi sempre decidido que sim. Quer dizer, praticamente toda a gente concordava com isso, ou todos. Nunca vi ninguém dizer que não... e na Argentina também foi uma política que foi definida e decidida de solidariedade, de não encerrar a fábrica. Apesar de ter havido despedimentos, começou por haver troca de pessoas de uma fábrica para a outra e depois haver aquilo que eles chamavam de trabalho partilhado, que era virem uns uma semana e outros outra. Portanto, não perdiam todos o salário, depois de esgotado todo o processo de formação e de recursos do

${ }^{66}$ Foi o que sucedeu com a GM-Europa e com o caso da Opel da Azambuja, não obstante o encerramento da fábrica portuguesa do Grupo GM no final de 2006. O papel do CEE da GM-Europa (constituído em 1996 por iniciativa do sindicato metalúrgico alemão IG-Metall) tornou possível a coesão, cooperação e solidariedade entre os trabalhadores do Grupo GM-Europa, superando assim (mesmo que apenas momentaneamente, em junho e julho de 2006) as diferenças entre representantes dos trabalhadores e as clivagens entre representações nacionais (Costa e Araújo, 2007c: 23; Costa, 2009a: 217-220).

67 Ou não fosse o CEE bem como o Conselho de Empresa Mundial (CEM) pilares do que se poderia designar um "sistema internacional de representação da força de trabalho" (Steiert, 2001: 118; 122). 
próprio governo. Até que aquilo ficou a produzir 40 carros por dia, só com pessoal da manutenção, e agora está a chamar todo esse pessoal outra vez, e está a crescer porque, entretanto, passou a crise económica lá (Representante português no CEE do Grupo VW, 17.11.2006).

A solidariedade implica, pois, ações concertadas e um abdicar de posições sectaristas. Como se disse acima, as reuniões entre representantes de trabalhadores criam uma cultura de aproximação entre eles e não de distanciamento, mesmo sabendo que existe uma predisposição (quase intuitiva) para que cada representante de cada país esteja sobretudo interessado nas mutações que venham a afetar a força de trabalho na sua fábrica. E mesmo tendo em conta a "disputa" que cada fábrica faz para que a produção de mais um veículo seja feita em sua “casa”. Daí que, na ótica dos representantes de trabalhadores nacionais, seja importante não só mostrar capacidade de trabalho junto das administrações (locais e centrais), mas igualmente accionar estratégias de convencimento junto dos representantes de trabalhadores da sede da VW, pois são eles que têm um papel decisivo e um direito de voto no referido conselho fiscal da VW que decide sobre as orientações/destinos da própria produção. A solidariedade joga-se, pois, muito neste campo da capacidade para influenciar (sem sectarismos ou contra outras filiais) os representantes de trabalhadores da sede da empresa com assento no conselho fiscal. Além disso, o capital simbólico (relacional) entre trabalhadores (designadamente entre representantes de trabalhadores mais experientes, como é o caso do representantes português do CEE do Grupo VW) pode também fazer a diferença:

Ainda agora tivemos aqui uma visita dos dez coordenadores das comissões de trabalhadores da Alemanha, dos quais oito têm assento nesse tal Conselho Fiscal, os outros dois são do IG-Metall (...). Ora, esses coordenadores de comissões de trabalhadores (pertencentes a várias fábricas da VW na Alemanha) são fiéis àquilo que é assumido no Comité Europeu. Eles estão lá todos no Comité Europeu [CEE] e assumem no Comité Europeu a defesa de um novo produto. Quando eles assumem que vão defender isto no Conselho Fiscal nós temos 80 
a 90\% de bipóteses das coisas saírem bem, pois é só uma questão de mais ano, menos ano. Eu recordo-me que quando foi para o Eos foi uma questão de um ano. Portanto, não foi naquele ano foi no ano imediatamente a seguir, tal como foi do Sirocco, tal como foi da Sharan. A sucessora da Sharan, falou-se em ser feita em muitos sítios, até por questões de logística, porque neste momento cada vez mais os carros, para serem mais leves, têm que levar chapa temperada, e nós não temos nem ninguém tem na Europa chapa temperada - a chapa temperada é feita só na Alemanha, em Kassel (...).

Todos os representantes dos trabalhadores nessas fábricas fazem lobby mesmo. Nós fazemos lobby, e é assumido que fazemos lobby. Eu tento fazer o máximo de lobby possível, até porque neste momento eu sou o segundo elemento mais velho do Comité Europeu, mais velho em termos de antiguidade, não em termos de idade. E isso dá-me um capital de interlocutor com os outros colegas das outras comissões de trabalhadores, e pessoalmente dos alemães, não é... Não é por acaso que eles começam a primeira viagem, a primeira fábrica que decidem visitar é a Autoeuropa neste projeto de saber "onde é que vamos colocar, onde é que vai haver maneira de colocar um outro produto".. (Representante português no CEE do Grupo VW, 18.10.2010).

\subsubsection{Um CEE cuja prática vai além do acordo formal}

$\mathrm{Na}$ análise que até aqui se tem feito do CEE do Grupo VW não foi ainda mencionado o texto do acordo que, em 1992, permitiu que o CEE visse a luz do dia. Em teoria, a referência a esse acordo deveria vir em primeiro lugar, pois são os acordos que servem de guia-orientador para as práticas dos CEEs. Porém só agora os termos do acordo são apresentados (ver abaixo quadro n. ${ }^{\circ}$ 39) precisamente porque para o representante do CEE do Grupo VW é notório que a prática é muito mais importante do que qualquer acordo, até porque essa prática supera o acordo (como de resto também já ficou dito na secção anterior, ao sustentar-se o persistente favorecimento da democracia laboral propiciado pelo CEE). 
QUADRO 39 - Acordo original do Conselho de Empresa Europeu do Grupo Volkswagen ${ }^{68}$

\begin{tabular}{|c|c|}
\hline & Conselho de Empresa Europeu \\
\hline Tipo de acordo & Artigo $13 .^{\circ}$ \\
\hline Signatários & $\begin{array}{l}\text { Direção do Grupo Volkswagen e Membros do CEE do Grupo } \\
\text { vW }\end{array}$ \\
\hline Data & 7 de fevereiro de 1992 \\
\hline Legislação aplicável & Legislação Belga \\
\hline Alcance geográfico & $\begin{array}{l}\text { Abrange todas as empresas controladas pelo Grupo VW, predo- } \\
\text { minantemente propriedade da VW AG (Volkswagen, Audi, Seat, } \\
\text { Skoda), e outras unidades que estejam em vias de integrar o } \\
\text { grupo na Europa. }\end{array}$ \\
\hline Duração do acordo & Não mencionado \\
\hline Composição & Representantes dos trabalhadores \\
\hline Atribuição de lugares & $\begin{array}{l}\text { - Volkswagen AG (8 representantes) } \\
\text { - Audi AG (2 representantes) } \\
\text { - SEAT SA (5 representantes) } \\
\text { - Volkswagen Bruxelles SA ( } 2 \text { representantes) } \\
\text { - Os representantes são em número de } 17 . \\
\end{array}$ \\
\hline $\begin{array}{l}\text { Eleição/nomeação dos } \\
\text { representantes dos } \\
\text { trabalhadores }\end{array}$ & $\begin{array}{l}\text { Os representantes dos trabalhadores no CEE do Grupo VW de- } \\
\text { verão ser eleitos democraticamente pelos órgãos representativos } \\
\text { dos trabalhadores da empresa que os designa e de acordo com } \\
\text { as disposições legais e regulamentares em vigor no respetivo } \\
\text { país. }\end{array}$ \\
\hline $\begin{array}{l}\text { Proteção dos } \\
\text { representantes dos } \\
\text { trabalhadores }\end{array}$ & Não mencionada \\
\hline Duração do mandato & $\begin{array}{l}\text { Os representantes no CEE do Grupo VW deverão ser eleitos a } \\
\text { cada eleição do órgão representativo dos trabalhadores da em- } \\
\text { presa que os designa. }\end{array}$ \\
\hline Formação & Não prevista \\
\hline Competências & $\begin{array}{l}\text { Os representantes dos trabalhadores têm o direito de ser infor- } \\
\text { mados e consultados pela Direção Central, em geral, sobre um } \\
\text { conjunto de matérias de importância reconhecida para as uni- } \\
\text { dades de produção europeias do Grupo VW. }\end{array}$ \\
\hline
\end{tabular}

68 O início das negociações para a criação do CEE deste grupo teve lugar em 1990 e a assinatura do $1 .^{\circ}$ acordo ocorreu em 1992 . Desde essa data procederam-se a várias alterações relacionadas com: o pagamento de despesas, aumento do $n .^{\circ}$ de representantes, por vezes em resultado de incorporação de novas marcas; criação de uma comissão de sociedades financeiras e distribuidoras; etc. Para uma análise detalhada dessas emendas ou ainda uma consulta de documentação relacionada com o texto do acordo do CEE do Grupo VW, cf. http://www.ewcdb.eu/show_body.php?body_ID=312. 


\begin{tabular}{|c|c|}
\hline & Conselho de Empresa Europeu \\
\hline $\begin{array}{l}\text { Questões objeto de } \\
\text { informação e consulta }\end{array}$ & $\begin{array}{l}\text { Conjunto de matérias de importância generalizada para o con- } \\
\text { junto de unidades de produção do Grupo VW na Europa: } \\
\text { - manutenção dos empregos e das fábricas, e estruturas das fá- } \\
\text { bricas; } \\
\text { - desenvolvimento das estruturas do Grupo VW; } \\
\text { - produtividade e estruturas de custos; } \\
\text { - desenvolvimento das condições de trabalho (por exemplo, } \\
\text { tempo de trabalho, pagamentos e salários, tipos de funções); } \\
\text { - novas tecnologias de produção; } \\
\text { - novas formas de organização de trabalho; } \\
\text { - trabalho em segurança, o que inclui proteção ambiental; } \\
\text { - os efeitos das decisões e políticas de desenvolvimento do Gru- } \\
\text { po Vw. }\end{array}$ \\
\hline $\begin{array}{l}\text { Oportunidade de } \\
\text { informação e consulta }\end{array}$ & $\begin{array}{l}\text { Os representantes do CEE ou o seu Comité Executivo deverão } \\
\text { ser informados em tempo útil quando as matérias em causa im- } \\
\text { plicam transferências de produção transfronteiriças com efeitos } \\
\text { substanciais perversos para os interesses dos trabalhadores de } \\
\text { fábricas do Grupo VW na Europa. } \\
\text { Os representantes do CEE ou o seu Comité Executivo deverão } \\
\text { ter o direito de avaliar num período de tempo adequado acorda- } \\
\text { do entre as partes aquando da receção da informação em causa. } \\
\text { Na fase de avaliação da informação os representantes do CEE ou } \\
\text { o seu Comité Executivo poderão pedir informações adicionais. } \\
\text { A consulta deverá ter lugar antes do processo de decisão estar } \\
\text { encerrado. }\end{array}$ \\
\hline Confidencialidade & $\begin{array}{l}\text { Os representantes do CEE não devem revelar a terceiros as in- } \\
\text { formações recebidas com expressa reserva de confidencialidade } \\
\text { nem as informações sujeitas pela sua natureza ao dever de sigilo } \\
\text { profissional. O dever de sigilo perdura para além do local em } \\
\text { que os obrigados se encontrem durante e após os respetivos } \\
\text { mandatos e da cessação das suas funções. }\end{array}$ \\
\hline $\begin{array}{l}\text { Recusa em prestar } \\
\text { informação }\end{array}$ & Inexistência de compromisso. \\
\hline $\begin{array}{l}\text { Recursos materiais e } \\
\text { financeiros }\end{array}$ & $\begin{array}{l}\text { O Grupo VW assume o pagamento de todas as despesas ineren- } \\
\text { tes ao funcionamento do CEE do Grupo VW de acordo com as } \\
\text { seguintes determinantes: } \\
\text { - custos de funcionamento do CEE do Grupo VW, incluindo os } \\
\text { custos de tradução e os custos dos representantes sindicais } \\
\text { designados pelo comité executivo; } \\
\text { - elaboração de um orçamento anual cujo montante será acor- } \\
\text { dado entre a Direção do Grupo e o CEE; } \\
\text { - os custos das reuniões do CEE serão suportadas pela empresa } \\
\text { do Grupo VW anfitriã da reunião. } \\
\text { - os custos relativos a deslocações dos representantes dos tra- } \\
\text { balhadores serão suportados pelas respetivas fábricas do Gru- } \\
\text { po VW às quais pertencem nos termos das regulamentações } \\
\text { em vigor. }\end{array}$ \\
\hline
\end{tabular}




\begin{tabular}{|c|c|}
\hline & Conselho de Empresa Europeu \\
\hline & $\begin{array}{l}\text { - as empresas do Grupo VW com representantes no CEE ficam } \\
\text { obrigadas a providenciar as infraestruturas necessárias ao de- } \\
\text { sempenho das suas funções e obrigações. }\end{array}$ \\
\hline Secretariado & $\begin{array}{l}\text { O CEE do Grupo VW elege um presidente que será simultanea- } \\
\text { mente membro e Presidente do Comité Executivo. } \\
\text { O CEE do Grupo VW elege um secretário-geral que será simulta- } \\
\text { neamente membro do Comité Executivo. } \\
\text { O CEE do Grupo VW elege um Comité Executivo. Cada país } \\
\text { representado deverá ter pelo menos um elemento no Comité } \\
\text { Executivo. O Comité Executivo pode designar membros adicio- } \\
\text { nais para consulta. }\end{array}$ \\
\hline $\begin{array}{l}\text { Número de reuniões/ano } \\
\text { sem Direção Central }\end{array}$ & Não previstas. \\
\hline $\begin{array}{l}\text { Número de reuniões/ano } \\
\text { com Direção Central }\end{array}$ & $\begin{array}{l}\text { Os representantes deverão reunir pelo menos uma vez por ano } \\
\text { com a Direção Central do Grupo VW. As reuniões são convoca- } \\
\text { das e organizadas pelo Comité Executivo. }\end{array}$ \\
\hline Reuniões extraordinárias & Não previstas. \\
\hline Reuniões preparatórias & Não previstas. \\
\hline Reuniões posteriores & Não previstas. \\
\hline Agenda & $\begin{array}{l}\text { Não se encontra especificada, contudo, é da responsabilidade do } \\
\text { Comité Executivo a convocação e organização da reunião anual. }\end{array}$ \\
\hline Difusão da informação & Não prevista. \\
\hline Língua de trabalho & Não especificada. \\
\hline Tradução & Prevista, custos suportados pela Administração do Grupo VW. \\
\hline Peritos & $\begin{array}{l}\text { Mediante resolução do Comité Executivo podem ser convidados } \\
\text { a participar nas reuniões do CEE consultores internos ou exter- } \\
\text { nos. O Comité Executivo pode nomear representantes sindicais } \\
\text { para assistir às reuniões do CEE. }\end{array}$ \\
\hline
\end{tabular}

Fonte: elaboração dos autores

Não espanta por isso que não só o acordo do CEE seja "desvalorizado", como o processo de revisão da Diretiva (que culminou na Diretiva 2009/38/CE) seja algo secundarizado:

Aquilo que eu conheço em relação ao caso concreto da Volkswagen é que não há qualquer tipo de alteração. O princípio mantém-se o mesmo, que é a aplicação dos acordos anteriores. Portanto, como o Comité Europeu da Volkswagen é anterior à própria Diretiva de 1994, mantém-se o mesmo sistema. Portanto, penso que não há nenbuma implicação, não tem havido nenhuma implicação na questão da [nova] Diretiva (...). 
Não houve nenhuma alteração. Não há nenhuma alteração. Há apenas mais empresas, que é o caso da SCANIA, que agora pertence também ao Grupo Volkswagen, da Lamborghini, da MAN, que ainda não está definido mas já tem observadores, falta ser oficializada a aquisição, e acho que está tudo. (...) Outra questão que estamos a criar neste momento prende-se com o CEE da Porsche, esse já sobre a nova Diretiva de 2009. Estamos neste momento em negociações com os sindicatos sobre quem é que serão os representantes. Em princípio serei eu porque é prática em toda a VW propor o representante no Comité Europeu da VW, o que está em discussão neste momento é quem será o suplente (...).

[o acordo refere "os representantes devem reunir pelo menos uma vez por ano com a Direção Central..."] mas nós reunimos três, continuamos a reunir três, quatro. Três a nivel europeu, que é o que interessa... (Representante português no CEE do Grupo VW, 18.10.2010).

A prática "avançada" do CEE do Grupo VW reside ainda no facto de ter maximizado outros mecanismos de diálogo social transnacional. Um deles foi a Carta Social da VW (designação por que ficou conhecida), assinada em Bratislava em 6.06.2002. Tratou-se de um marco das relações laborais no universo da VW, não só por caminhar para uma harmonização transnacional das relações laborais, como por colocar ênfase nas formas de responsabilidade social das empresas (Steiert, Uhl e Brüning, 2002: 711-712). O referido documento - intitulado Declaração sobre direitos sociais e relações industriais na Volkswagen - foi subscrito pela direção central da VW, pela CT do Grupo Mundial VW e pela Federação Internacional dos Trabalhadores das Indústrias Metalúrgicas (FITIM), tendo-se baseado nas principais convenções da OIT $^{69}$.

69 São objetivos fundamentais da Carta Social: o "direito fundamental que todos os trabalhadores têm de constituir sindicatos e representações laborais e aderir aos mesmos"; a "igualdade de oportunidades e tratamento, independentemente da raça, cor, sexo, religião, nacionalidade, orientação sexual, origem social e posições políticas ficam salvaguardadas"; o declinar de "todo e qualquer aproveitamento científico do trabalho forçado e obrigatório, incluindo a escravidão ou trabalho prisional involuntário"; a proibição do trabalho de menores pois "a idade mínima para admissão no trabalho é respeitada nas condições previstas pelas regulamentações nacionais"; a salvaguarda de um "ambiente de trabalho seguro e higiénico"; "as remunerações e prestações pagas ou executadas em relação à 
Outro dos mecanismos de diálogo e participação laboral que vem na sequência daquela Carta Social de 2002 - que favorecia uma "boa governação global", ou seja, o auto-compromisso de todos os atores sociais e económicos em relação aos princípios sociais, éticos e ecológicos que transcendem os quadros estabelecidos legalmente no contexto global - é a Carta das relações laborais no Grupo Volkswagen, celebrada em 29.10.2009 entre a administração mundial da VW, as CTs europeias e mundial e a FITIM. Trata-se de uma carta em que se confirma a tradição de cultura de participação de que se falava acima e que tem enquadrado a atividade do CEE do Grupo VW. Esta Carta vem aplicar-se a todas as empresas e unidades industriais representadas na CT europeia e na CT mundial do Grupo Volkswagen e vem definir os direitos de participação na empresa. As partes reconhecem as distintas tradições sindicais dos países do Grupo VW, assumindo conjuntamente o objetivo de desenvolvimento das relações laborais coletivas a nível local. A Carta estabelece um quadro vinculativo para a continuação do desenvolvimento responsável das relações laborais existentes, no sentido da cooperação na resolução de conflitos. Como pode ler-se no seu preâmbulo:

No quadro da cultura de produção e participação, "produção" significa uma colaboração ativa, competente e comprometida de trabalhadores, associações de trabalhadores e direções para o sucesso global da empresa.

"Participação" significa que os trabalhadores são ativamente envolvidos no desenvolvimento da empresa, contribuindo para uma melhoria contínua dos processos e condições de trabalbo e participando no sucesso.

\footnotetext{
semana normal de trabalho, correspondem, no mínimo, aos respetivos padrões mínimos nacionais ou padrões mínimos dos respetivos setores económicos nacionais"; "o horário de trabalho corresponde, no mínimo, aos respetivos requisitos legais nacionais ou padrões mínimos dos respetivos setores económicos nacionais" (VW AG; Comissão de Trabalhadores do Grupo Mundial VW; FITIM, 2002: 1-3). Considerada mais avançada do que as diretrizes da OCDE para as multinacionais ou mesmo do que o Global Compact (iniciativa das Nações Unidas que, como já se disse, visa mobilizar a comunidade empresarial internacional para a promoção de valores fundamentais nas áreas dos direitos humanos, do trabalho e do ambiente), a Carta Social da VW tem ainda a particularidade de recomendar vivamente às empresas fornecedoras que se insiram nos padrões e relações de trabalho existentes da VW (Steiert, Uhl e Brüning, 2002: 712-713), configurando-se como um autêntico Acordo-Quadro Global (A-QG), nos termos definidos no capítulo 1.
} 
A participação é moldada por uma relação cooperativa e respeitosa das partes e a consciência da responsabilidade conjunta pela empresa e pelos trabalhadores. A definição e a concretização ativa dos direitos de participação são um fator de organização inovador na empresa.

Seguindo estas ideias orientadoras de "Produção e Participação", a presente Carta oferece, definidos nesta Carta, direitos de participação a nível local que, no quadro de acordos locais concretos, são implementados entre as partes. Este compromisso mútuo desenvolve o equilíbrio correto entre a capacidade de concorrência, a garantia dos postos de trabalbo e o bem-estar dos trabalhadores (VW AG; CT Europeia do Grupo VW; CT Mundial do Grupo VW; FITIM, 2009: 1).

Além dos direitos de participação das associações de trabalhadores em assuntos financeiros e em assuntos de política de recursos humanos e sociais da empresa, da definição de regras relativas à celebração do "acordo de participação específico de unidade" e da definição de regras gerais de procedimento após a celebração do acordo, merece destaque a clarificação que é feita de conceitos em matéria de direitos de participação, designadamente de informação, consulta e co-gestão:

(1) O direito à informação compreende a informação em tempo oportuno $e$ completa da representação de trabalhadores na empresa, para lhe conceder a oportunidade de tomada de conbecimento e formação de opinião em relação ao estado de coisas negociado. "Em tempo oportuno" significa informar acerca das medidas logo no início de um processo de planeamento. "Completa" significa que todos os aspetos e dados relevantes são apresentados de uma forma clara. A implementação de uma medida implica a informação prévia.

(2) O direito a consulta compreende um diálogo ativo entre a representação de trabalhadores na empresa e a direção, para assegurar o direito de iniciativa e de expressão da representação de trabalhadores em relação ao estado de co $i$ sas negociado e, se necessário, aconselhar sobre a prevenção de consequências negativas. A implementação de uma medida implica a consulta prévia.

(3) O direito à co-gestão compreende um direito de acordo, controlo e iniciativa da representação de trabalhadores na empresa para uma co-decisão $e$ 
co-responsabilização ativa. A implementação de uma medida implica a concordância prévia (VW AG; CT Europeia do Grupo VW; CT Mundial do Grupo VW; FITIM, 2009: 2).

Ao comentar a importância desta Carta das Relações Laborais, o representante português dos trabalhadores no CEE do Grupo VW, simultaneamente coordenador do CT da Autoeuropa, realçou o direito à co-gestão (ainda que este nem sempre seja pacífico em todas as fábricas da VW à escala mundial), bem como o papel (missão) "descentralizador" do CEE neste domínio e a cultura de segurança e bem-estar trazidas pelo documento.

A Carta das Relações Laborais é uma mais-valia mas também é uma espada de dois gumes, sobretudo porque tem as questões da co-gestão que está a custar a engolir a alguns sindicatos mais de esquerda, digamos assim. São uns anti co-gestão, combatem a co-gestão a todo o transe. Mas eu penso que está bem constituída, porque a gente se quer ter uma participação decisiva numa série de questões que lá vêm, também temos que ter responsabilidades...

E o papel do CEE foi fazer aquilo. Agora um dos pontos da ordem de trabalhos vai ser a empresa, a administração da empresa, a ter que justificar os recursos humanos, como é que está a situação da negociação da Carta em cada localidade, portanto, em cada localização (...). Na Alemanha está negociado, está assente, foi assinada, é aquilo que está na íntegra. Agora, há países onde aquilo ainda não está na íntegra colocado. Por exemplo, os brasileiros têm problemas com a co-gestão, apesar de tudo. "Eh, pá, sim senhor, a gente quer só decidir quando é para admitir, mas não queremos participar quando é para despedir". Portanto, aí é difícil de encontrar uma aplicação da Carta. Nós aqui não temos esse problema, temos comissão de trabalhadores. E provou-se isso com a crise. Pegámos nas pessoas, eram temporários, é verdade, mas arranjámos-lhes uma ação de formação paga e hoje estão cá, e com contrato com a Autoeuropa, não são temporários. Acabaram o curso e passaram a contrato com a Autoeuropa, não voltaram à agência de trabalbo temporário". (Representante português no CEE do Grupo VW, 18.10.2010). 
Ora, a Carta das Relações Laborais - na qual, como se assinalou, se descrevem as matérias em que a CT deve ser informada e consultada e quais as matérias que decorrem de uma decisão conjunta com as administrações - viria a ser assinada pela administração da Autoeuropa e pela CT em 15.11.2010. Como reconhecia o Diretor Geral da Autoeuropa no momento dessa celebração: "É um ato formal mas, mais do que isso, oficializa o modo como queremos trabalhar no Grupo Volkswagen, entre Administrações e Comissões de Trabalhadores. A Carta define quais são as responsabilidades e partilhas de ambas as partes para a continuação de uma cultura de confiança e respeito nas relações laborais" (António Pires, Jornal da Autoeuropa, 145, novembro/dezembro 2010).

Estes dois exemplos - Carta Social (2002) e Carta das Relações Laborais (2009) -, e certamente outros ${ }^{70}$, foram testemunhados de perto pelo CEE e estimulados por ele, evidenciando formas mais abrangentes de tratar a informação e a consulta.

\subsubsection{Um CEE pragmático e participativo}

Uma das limitações associadas ao funcionamento do CEE é (como foi salientado anteriormente) o desconhecimento dos destinos dos investimentos futuros da empresa, pois daí decorre em grande medida a perceção da confiança com que se encara o futuro. Ou seja, trata-se, no fundo, de

70 Ao verificar que nos últimos anos muitos Estados Europeus se têm mantido em clima de estagnação social - fruto de cortes nas pensões, sistemas de saúde e direitos de proteção dos trabalhadores ou em resultado das tendências de flexibilização dos mercados de trabalho, entre outros pontos -, numa resolução aprovada em 30.09.2010, a Presidência do Comité de Trabalhadores do Consórcio Europeu apelou vivamente à UE a deixar de centrar a sua atenção no espaço económico comum para passar a centrar-se numa Europa dos cidadãos/ãs, na qual os interesses dos trabalhadores/as tenham o mesmo valor que o mercado único e as disposições que o regulam. Para o referido Comité - em representação das dez marcas do Consórcio VW, de mais de 30 unidades espalhadas por 15 países europeus e, subsequentemente, de mais de 280.000 trabalhadores -, é crucial a equiparação das condições de vida na Europa, não podendo haver um nivelamento para implementação de medidas medianas. E dá dois exemplos: os direitos dos trabalhadores e os direitos de co-gestão vigentes na Alemanha, nomeadamente os desenvolvidos direitos dos trabalhadores europeus da VW; e os regimes de proteção social e de políticas educativas em países escandinavos, como a Suécia. 
cumprir a própria diretiva nos objetivos que ela estipula, i.e., de pelo menos ser informado e consultado em tempo útil sobre os locais (destinos) onde a VW tenciona realizar investimentos futuros. A atitude normal (nomeadamente por parte da administração) é que essa informação e consulta sejam prestadas aos trabalhadores, embora em muitos CEEs a regra seja não transmitir essa informação atempadamente, impedindo, pois, o CEE (e por extensão os trabalhadores que este representa) de exercer alguma influência ou forma de pressão sobre uma iniciativa ou posição empresarial. Mas no CEE do Grupo VW essa situação tem efetivamente assumido contornos de normalidade, pelo que se trata de um problema que tem sido torneado e (como se enfatizou acima) os trabalhadores são envolvidos nos processos de tomada de decisão numa fase preliminar. Ainda assim, porque os interesses patronais não se confundem com os interesses laborais (sindicais), a necessidade de ser informado em tempo útil será sempre uma constante do dia-a-dia dos trabalhadores (em cada filial) mas igualmente dos CEEs em geral e não apenas deste CEE do Grupo VW:

A gente tenta conseguir informação aqui dentro da empresa sobre se há investimento ou não. Ao que parece não há. Portanto, a VW está a canalizar todo o investimento para o Brasil e para a China, e portanto, nós vamos levantar essa questão. Neste momento é uma das questões mais fraturantes (Representante português no CEE do Grupo VW, 17.11.2006 e 18.10.2010).

Mas isso não invalida, até por tudo o que foi dito até aqui, que o CEE do Grupo VW não seja considerado, por quem faz parte dele, como um exemplo ou referência a seguir em virtude do ser carácter de exceção:

Este tipo de experiência da VW devia ser conbecido de todos os CEEs, para que as pessoas também ouvissem e pudessem elas próprias ir mudando a sua atitude face aos CEEs (...) Não há nenhum comité europeu em Portugal que tenha esta dimensão e este tipo de reunião, e esta abertura e esta discussão, e esta exigência do próprio Presidente do Comité Europeu e do Comité Mundial junto da direção do Grupo de prazos para apresentarem soluções aos 
problemas que colocamos. Portanto, não é normal. Mas isso também é fruto da situação em que se enquadra a própria $V W$ (Representante português no CEE do Grupo VW, 18.10.2010).

Em síntese, a tradição de cultura negocial da VW, a "lei-VW" que a sustenta e a reforça, o não encerramento de fábricas, a preocupação com os problemas das filiais consideradas isoladamente e a resolução (ou empenho coletivo e firme na tentativa de resolução) dos problemas (primeiro nacionalmente e depois, caso no local não haja entendimento, via CEE), a concretização de uma prática do CEE que vai além dos termos formais do acordo que lhe dá vida (mais reuniões, mais solidariedade, dinamização de focos de diálogo social transnacional em resultado da existência do CEE ou instigadas pela ação deste, maior conhecimento sobre a empresa e também sobre o setor, etc.) são apenas alguns dos fatores que tornam plausível classificar este CEE como "CEE participativo" ou "eurocêntrico", nos termos das tipologias propostas por Lecher et al e por Bicknell respetivamente e que foram analisadas no capítulo 2 . Nesse sentido, não admira que seja o próprio representante português do CEE da VW a colocar o CEE da VW no patamar mais elevado das tipologias de CEEs, atitude que, assinale-se, foi assumida de modo quase que intuitivo e confimando o rol de boas práticas do CEE da VW.

\subsubsection{O CEE do Grupo Air Liquide ${ }^{71}$}

O contexto em que atua qualquer CEE é indissociável da empresa multinacional/grupo onde o CEE se enquadra. A perceção da dimensão da atividade empresarial (neste caso do Grupo Air Liquide) é, pois, fundamental para perceber o tipo de respostas que o CEE é capaz de dar.

${ }^{71}$ A análise deste estudo de caso beneficiou significativamente da entrevista realizada com o representante do CEE do Grupo Air Liquide em outubro de 2010. Ver igualmente entrevista com o mesmo representante realizada em 2007 e disponível em Costa e Araújo (2007b: 439-441). 


\subsubsection{Objetivos e áreas de intervenção do Grupo Air Liquide}

O Grupo Air Liquide é líder mundial de gás para a indústria, a saúde e o ambiente. Apoiando-se em tecnologias inovadoras baseadas em processos em constante renovação, a Air Liquide produz diferentes tipos de saídas de gases (oxigénio, azoto, gases raros), assim como outro tipo de gases como hidrogénio.

Um olhar atento sobre o sítio oficial do Grupo (www.airliquide.com/ fr) permite constatar as suas principais áreas de atuação e os seus desafios estratégicos à escala internacional. Ainda que corresponda, como em certo sentido é expectável, a uma estratégia de marketing do Grupo, a exposição de tais dados é sobretudo útil para percebermos também o modo favorável como o representante do CEE da Air Liquide (que é simultaneamente membro do Conselho Restrito/CR, que na empresa tem a designação de Bureau) olha para instituições europeias como os CEEs.

Presente em 80 países, dispondo aproximadamente de 50.000 empregados e contando com 390.000 accionistas individuais (responsáveis por 37\% do capital), o Grupo Air Liquide fornece mais de um milhão de clientes em domínios/setores diversificados (que vão desde a siderurgia ao agro-alimentar, passando pela eletrónica ou a indústria farmacêutica) e nas profissões de saúde. Em 2010, o Grupo apresentou resultados líquidos de 1.404 milhões de euros, ao passo que em 2011 esse montante subiu para 1.535 milhões de euros e em 2012 para 1.609 milhões de euros. ${ }^{72}$ Ainda de acordo com o site oficial do Grupo, constata-se uma atuação nos domínios: do ambiente (pois a produção industrial cria efeitos nefastos no ambiente, na evolução climática e na saúde humana, pelo que se torna urgente desenvolver soluções orientadas para limitar as emissões de gases nocivos resultantes da indústria); da saúde (tanto mais que o prolongamento da idade de vida das pessoas vai de par com o crescimento de doenças crónicas, pelo que se justifica o acompanhamento permanente de pacientes quer em hospitais, quer nos domicílios); da energia (uma

72 http://www.airliquide.com/en/company/who-we-are/financial-results.html, acedido em 19.06.2013. 
vez que os recursos fósseis tradicionais, carvão, petróleo e gás natural têm vindo a diminuir gradualmente ao passo que as necessidades de energia aumentam constantemente, torna-se necessário/urgente utilizar de forma mais eficaz formas de energia alternativas como são os casos da energia fotovoltaica, hidrogénio enquanto produtor de eletricidade própria, biocarburantes de segunda geração, etc.); das altas tecnologias (traduzindo-se, neste caso, numa atuação assente no desenvolvimento de uma matriz única de gases em condições excecionais de alta pressão, baixa temperatura e elevada pureza).

O Grupo Air Liquide aposta ainda, em paralelo, num conjunto de estratégias que passam pelos seguintes pontos: configurar-se como empresa social; dinamizar parcerias de longa duração; reforçar a condição de empresa cidadã; prevenir os conflitos de interesses. No que concerne à ideia de empresa social, o que perpassa nas preocupações do Grupo é a transmissão de valores e de estratégias de envolvimento social, o recrutamento e fidelização de competências ajustadas às necessidades atuais e de crescimento futuro. Nestes termos, em matéria de responsabilidade social, a Air Liquide fixou três objetivos principais: reforçar a presença feminina, designadamente através do recrutamento de mulheres (engenheiras e quadros), embora se constante que em 2009 a percentagem destas categorias igualou a proporção global de mulheres no Grupo (24\%); reforçar as ações de formação de modo a que cada assalariado possa potenciar as suas competências, beneficiando de pelo menos 3 dias de formação por ano; promover, para $100 \%$ dos assalariados, uma entrevista anual de apreciação dos seus desempenhos com a sua hierarquia e em cada 3 anos uma entrevista de carreira com o diretor de recursos humanos.

Quanto à estratégia de parcerias de longa duração, destaca-se a preocupação do Grupo em estabelecer e consolidar relações de confiança com accionistas individuais (cerca de 410.000 e detentores de $37 \%$ do capital) e investidores institucionais. Nesse sentido, desenvolveu uma Carta do Accionista em redor dos seguintes pilares: demonstrar consideração e respeito para com os accionistas ; escutá-los e informá-los; atribuir-lhes serviços específicos, por meio de um Serviço de accionistas, etc. 
A ideia de empresa cidadã, por sua vez, assenta num conjunto de linhas: preservação da vida e do ambiente (por meio da medição do consumo energético e da limitação do seu impacto ambiental, construindo para o efeito um conjunto de indicadores que medem as quantidades de emissões de gases com efeitos de estufa); desenvolvimento durável no quotidiano, designadamente das atividades quotidianas dos seus colaboradores; objetivo "zero acidentes", o que significa que uma cultura de segurança é prioritária tanto para fornecedores como para clientes; uma responsabilidade para com os fornecedores, devendo a Air Liquide integrar os seus fornecedores no compromisso de responsabilidade social e ambiental; um envolvimento ético e societal, através da promoção de sólidos princípios éticos.

Por fim, a estratégia de prevenção de conflitos de interesses. Nesse sentido, no domínio das relações com um concorrente, cliente ou fornecedor, os colaboradores estão obrigados a evitar todo o tipo de situações que impliquem um conflito entre os seus interesses pessoais e os interesses da Air Liquide. Na verdade, pode constituir-se como conflito de interesses o facto de um colaborador trabalhar simultaneamente para um cliente, um fornecedor ou um concorrente ou de possuir interesses significativos direta ou indiretamente relacionados com estes últimos. Por outro lado, torna-se crucial respeitar regras no domínio ético de modo a evitar quaisquer situações de corrupção, sendo por exemplo expressamente proibido conceder vantagens (diretamente ou por meio de um intermediário) a um particular ou a um representante de poderes públicos com o propósito de obter um tratamento favorável ou influenciar questões ou matérias que sejam do interesse da Air Liquide.

Em Portugal, nos termos da informação disponível no site português do Grupo Air Liquide (http://www.airliquide.pt/pt/quem-somos/air-liquide-portugal.html), a Sociedade do Ar Líquido, filial da multinacional Air Liquide, viu a luz do dia em 1923 com o propósito de vender oxigénio e outros gases industriais. Tendo sido a primeira empresa de gases industriais a iniciar a sua atividade em território nacional, acompanhou desde o início o desenvolvimento da indústria portuguesa e passou com ela as diferentes etapas da sua evolução. A Air Liquide Portugal serve mais 
de 35000 clientes através das suas três atividades: atividade industrial (Sociedade Portuguesa do Ar Líquide), atividade medicinal (Air Liquide Medicinal para hospitais e ao domicílio) e a atividade de soldadura (Air Liquide Soldadura).

\subsubsection{Nascimento e funcionamento do CEE}

O CEE do Grupo Air Liquide começou a ganhar forma em 1993 mas a constituição do CEE só se consumou em 1996. Inicialmente seria composto por 9 elementos, mas no final de 2010 faziam parte do CEE deste Grupo 16 representantes. Tem um Conselho Restrito (CR) composto por 5 elementos (sendo o representante português um deles, o que se explica em parte também pela sua antiguidade), todos de países diferentes. A reunião formal do CEE acontece uma vez por ano (embora se esteja a tentar alargar para duas reuniões anuais), em Paris, durante três a quatro dias. Contudo, o CR reúne quatro vezes por ano, sempre em países diferentes: “o Bureau reúne quatro vezes por ano, normalmente é em janeiro, em março é a Plenária, em junho é o Bureau, em outubro é o Bureau e volta a janeiro" (representante português no Bureau do CEE do Grupo Air Liquide, 12.10.2010).

A composição da força de trabalho em Portugal (fator importante para perceber a elegibilidade dos representantes) é de 311 trabalhadores, repartidos por 3 áreas de intervenção: "Nós em Portugal somos 185 na parte Agro-industrial, depois temos a parte Medicinal que foi separada pelo facto de o medicamento hoje ser considerado um fármaco, e é tratado como um fármaco, é rastreado, etc., são 110 pessoas; e a área da Soldadura que inclui 16 pessoas. São as três áreas que nós temos em Portugal do Grupo Air Liquide" (representante português no Bureau do CEE do Grupo Air Liquide, 12.10.2010).

O representante português pertence assim ao "grupo dos eleitos" do CEE, i.e., ao CR (Bureau) que tem um papel-chave no funcionamento do CEE: 
O Bureau, que é o secretariado que empreende ações em função da informação que colbe nos vários países que pertencem ao CEE, procura ver onde é que podemos ajustar as informações aos outros países da Europa onde existe o Grupo Air Liquide. Essa é a função de um CEE, aplicar as melhores práticas e que elas sejam comuns, tanto quanto possível, àquilo que é praticado na sede. Salvaguardando sempre, naturalmente, no aspeto financeiro, a situação de cada país e a legislação, como é evidente. Mas, tanto quanto possível, procuramos aplicar isso nos diversos países de forma a que as condições de trabalbo (e tudo o que gira em torno da área laboral) sejam, realmente, iguais em todos os países da Europa (Representante português no Bureau do CEE do Grupo Air Liquide, 12.10.2010).

\subsubsection{Um acordo em segundo plano face à "prática"}

Embora alguns investigadores considerem exitir uma relação direta entre as disposições contidas nos acordos de CEEs e as práticas que delas decorrem (Marginson et al., 1998; Carley e Marginson, 2000; Gilman e Marginson, 2004), para outros a letra dos acordos e as dinâmicas de que os CEEs são portadores não são necessariamente coincidentes (Ramsay, 1997; Blanpain, 1998; Paternotre, 1998; Waddington, 2003; Wills, 2004; Telljhoann, 2005b; Costa and Costa, 2011; Costa, 2013).

Tal como se constatou no exemplo da Autoeuropa, também o representante do CEE do Grupo Air Liquide não coloca os aspetos formais associados ao texto do acordo do CEE em primeiro lugar: "O acordo em si não é importante, o que é importante é depois o que se faz na prática. O que o acordo faz é estabelecer algumas regras que devem existir para que haja alguma organização, mas depois tudo depende da forma como as coisas vão acontecendo" (representante português no Bureau do CEE do Grupo Air Liquide, 12.10.2010).

O representante português neste CEE "limita-se" por isso quase que a identificar alguns aspetos do acordo (cujo conteúdo original se reproduz no quadro 40), mas sem entrar nos detalhes da sua explicação. 
QUADRO 40 - Acordo original do Conselho de Empresa Europeu do Grupo Air Liquide ${ }^{73}$

\begin{tabular}{|c|c|}
\hline & Conselho de Empresa Europeu \\
\hline Tipo de acordo & Artigo $6 .^{\circ}$ \\
\hline Signatários & Grupo Especial de Negociação e Direção Central \\
\hline Data & 16 de maio 2000 \\
\hline Legislação aplicável & Legislação francesa \\
\hline Alcance geográfico & $\begin{array}{l}\text { Abrange todas as empresas do Grupo Air Liquide com sede nos } \\
\text { Estados-membros da União Europeia. }\end{array}$ \\
\hline Duração do acordo & $\begin{array}{l}\text { Quatro anos a partir da data da primeira reunião plenária. Poderá } \\
\text { ser reformulado antes desta data, quando a maioria dos represen- } \\
\text { tantes do CEE assim o decidir, até ao limite da reunião que precede } \\
\text { o término do período de quatro anos. Poderá ser denunciado por } \\
\text { qualquer uma das partes com uma antecedência de seis meses antes } \\
\text { do prazo dos quatro anos terminar. }\end{array}$ \\
\hline Composição & $\begin{array}{l}\text { Representantes da Administração Central e representantes dos tra- } \\
\text { balhadores. }\end{array}$ \\
\hline Atribuição de lugares & $\begin{array}{l}\text { Administração Central: } \\
\text { - O Diretor Executivo da Air Liquide (coadjuvado pelos Diretores } \\
\text { das diversas atividades comerciais ou países, dependendo dos } \\
\text { itens da agenda); } \\
\text { - Diretor of Staff Relations; } \\
\text { - Diretor dos Recursos Humanos para a Europa. } \\
\text { Representantes dos Trabalhadores ( } 1 \text { representante por cada país } \\
\text { onde existam entre } 500-1500 \text { trabalhadores; } 2 \text { representantes por } \\
\text { cada país onde existam mais de } 1500 \text { trabalhadores): } \\
\text { - França: } 7 \text { representantes; Itália e Alemanha: } 3 \text { representantes } \\
\text { cada; Espanha e Bélgica: } 2 \text { representantes cada; Portugal, Suécia, } \\
\text { Grécia e Holanda: } 1 \text { representante cada. Total: } 21 \text { representantes. } \\
\text { O número de representantes não deverá exceder as } 30 \text { pessoas. }\end{array}$ \\
\hline $\begin{array}{l}\text { Eleição/nomeação dos } \\
\text { representantes dos } \\
\text { trabalhadores }\end{array}$ & $\begin{array}{l}\text { Os representantes dos trabalhadores deverão ser eleitos/designados } \\
\text { de entre os trabalhadores do Grupo Air Liquide no ativo, de acordo } \\
\text { com o estipulado na Lei ou práticas em vigor nos Estados-membros } \\
\text { de onde são provenientes. }\end{array}$ \\
\hline $\begin{array}{l}\text { Proteção dos } \\
\text { representantes dos } \\
\text { trabalhadores }\end{array}$ & Prevista. \\
\hline Duração do mandato & $\begin{array}{l}\text { Quatro anos, renováveis, a contar da data da primeira reunião ple- } \\
\text { nária. }\end{array}$ \\
\hline Formação & Não prevista. \\
\hline
\end{tabular}

73 O conteúdo deste acordo reporta-se ao ano 2000, por sinal o único que, à data de junho de 2013, se encontrava disponível na base de dados do Instituto Sindical Europeu (http://www.ewcdb.eu/show_agreement.php?agreement_ID=656). 


\begin{tabular}{|c|c|}
\hline Competências & $\begin{array}{l}\text { O CEE da Air Liquide é um órgão para o aprofundamento do diálogo } \\
\text { e a troca de pontos de vista entre a administração Central e os repre- } \\
\text { sentantes dos trabalhadores sobre questões de natureza económica, } \\
\text { financeira e social que pela sua importância estratégica ou carácter } \\
\text { global digam respeito ao grupo no seu todo ou, no mínimo, afetem } \\
\text { pelo menos duas sucursais em países abrangidos pelo acordo. }\end{array}$ \\
\hline $\begin{array}{l}\text { Questões objeto de } \\
\text { informação e consulta }\end{array}$ & $\begin{array}{l}\text { Partindo da apresentação de um relatório anual sobre o desenvol- } \\
\text { vimento das atividades do Grupo, as matérias de informação e con- } \\
\text { sulta serão: } \\
\text { - a estrutura, a situação económica e financeira; as previsões de } \\
\text { desenvolvimento das atividades do Grupo; produção e vendas; a } \\
\text { situação de emprego atual e futura; investimentos, mudanças sig- } \\
\text { nificativas na organização; a introdução de novas práticas ou pro- } \\
\text { cessos de trabalho; transferências de produção; fusões, cortes nas } \\
\text { atividades produtivas; encerramento total ou parcial de unidades } \\
\text { produtivas com impactos ao nível do emprego; despedimentos } \\
\text { coletivos; segurança e ambiente; formação. }\end{array}$ \\
\hline $\begin{array}{l}\text { Oportunidade de } \\
\text { informação e consulta }\end{array}$ & Inexistência de compromisso. \\
\hline Confidencialidade & $\begin{array}{l}\text { Os representantes do CEE ficam sujeitos ao dever de confidencia- } \\
\text { lidade de acordo com as condições especificadas no Artigo } 8 \text { da } \\
\text { Diretiva Europeia 94/45/CE de } 22 \text { setembro de } 1994 \text {. }\end{array}$ \\
\hline $\begin{array}{l}\text { Recusa em prestar } \\
\text { informação }\end{array}$ & Não prevista. \\
\hline $\begin{array}{l}\text { Recursos materiais e } \\
\text { financeiros }\end{array}$ & $\begin{array}{l}\text { O tempo gasto pelos membros do CEE nas reuniões preparatórias } \\
\text { e plenárias assim como o que decorre das viagens e estadas para } \\
\text { efeitos das mesmas deverão ser pagos de acordo com as regras e ta- } \\
\text { belas vigentes nas sucursais do Grupo que representam. As viagens } \\
\text { deverão ser efetuadas por meio aéreo e deverão ser organizadas e } \\
\text { pagas pela empresa à qual os representantes pertencem. } \\
\text { Os recursos materiais e financeiros necessários à organização das } \\
\text { reuniões são suportados pela Air Liquide SA. }\end{array}$ \\
\hline Secretariado & $\begin{array}{l}\text { O CEE é presidido pelo Diretor Geral da Air Liquide. } \\
\text { O CEE deverá eleger, por uma maioria de votos, um secretário/a e } \\
\text { três membros de entre os representantes dos trabalhadores (de dife- } \\
\text { rentes nacionalidades), que constituirão o Comité Restrito (Bureau). }\end{array}$ \\
\hline $\begin{array}{l}\text { Número de reuniões/ } \\
\text { ano sem Direção } \\
\text { Central }\end{array}$ & Não previstas. \\
\hline $\begin{array}{l}\text { Número de reuniões/ } \\
\text { ano com Direção } \\
\text { Central }\end{array}$ & $\begin{array}{l}\text { Uma vez por ano, convocada pelo Presidente e pela secretária do } \\
\text { CEE, com a duração de um dia, podendo estender-se por mais meio- } \\
\text {-dia se a agenda assim o exigir. }\end{array}$ \\
\hline
\end{tabular}




\begin{tabular}{|c|c|}
\hline $\begin{array}{l}\text { Reuniões } \\
\text { extraordinárias }\end{array}$ & $\begin{array}{l}\text { Sob circunstâncias excecionais que afetem os interesses dos traba- } \\
\text { lhadores de vários países da União Europeia, o Presidente do CEE e } \\
\text { a secretária poderão convocar uma reunião extraordinária do CEE. } \\
\text { O CEE da Air Liquide poderá convocar uma reunião extraordinária a } \\
\text { pedido de dois terços dos seus membros. }\end{array}$ \\
\hline Reuniões preparatórias & $\begin{array}{l}\text { Os membros do CEE poderão reunir-se entre si no dia anterior à } \\
\text { data da reunião plenária, durante um dia completo. }\end{array}$ \\
\hline Reuniões posteriores & Não previstas. \\
\hline Agenda & $\begin{array}{l}\text { A agenda é definida em conjunto pelo Presidente e pelo secretário } \\
\text { ou seu representante depois de consultados o Conselho Restrito e } \\
\text { a Administração Central. Deverá ser enviada aos membros do CEE } \\
\text { com, pelo menos, um mês de antecedência da data da reunião ple- } \\
\text { nária, assim como os documentos necessários. }\end{array}$ \\
\hline Difusão da informação & $\begin{array}{l}\text { Nas empresas e estabelecimentos cobertos pelo âmbito de aplicação } \\
\text { deste CEE, e de acordo com as regras e procedimentos em vigor em } \\
\text { cada um deles, a Administração deverá divulgar aos trabalhadores: } \\
\text { - a lista de membros do comité restrito do CEE; } \\
\text { - a lista de membros do CEE; } \\
\text { - as atas das reuniões plenárias do CEE. }\end{array}$ \\
\hline Língua de trabalho & Não especificada. \\
\hline Tradução & Prevista, durante as reuniões e de documentos de trabalho. \\
\hline Peritos & $\begin{array}{l}\text { Previstos. Deverão ser escolhidos preferencialmente entre os mem- } \\
\text { bros do pessoal pertencentes às empresas do Grupo. A sua partici- } \\
\text { pação deve limitar-se à reunião plenária e apenas nos assuntos que } \\
\text { lhes digam especificamente respeito. A secretária deve informar o } \\
\text { Presidente do CEE com pelos menos três meses de antecedência } \\
\text { da data da reunião plenária da intenção do comité restrito convidar } \\
\text { peritos. }\end{array}$ \\
\hline
\end{tabular}

Fonte: elaboração dos autores

Este desprendimento (que por vezes parece mesmo confundir-se com desconhecimento) face aos aspetos formais do acordo é extensível ao processo de revisão da Diretiva (e, portanto, à Diretiva 2009/38/CE em vigor), por sinal pouco amadurecida inclusive no seio do CR:

Por incrível que pareça nenhum dos meus colegas membros do Bureau ainda está familiarizado com a nova Diretiva [2009/38/CE], onde eu me incluo também. Não estou neste momento apto para lhe dar uma ideia muito concreta do que é que traz de melhorias ou o que é que melhorou em relação à anterior ou o que é que atualizamos em relação ao que é boje o panorama dos comités europeus de empresa. Não estou habilitado, neste momento, a dizer algo mais 
concreto. De toda a forma, em relação a isso, nós estamos a fazer alterações ao regulamento interno que foi feito, criado na altura a partir da Diretiva de 1994, e vamos tentar aplicar, tanto quanto possível na remodelação de alguns artigos. Já o que diz a nova Diretiva, é um projeto que ficámos de estudar todos, cada um no seu país (Representante português no Bureau do CEE do Grupo Air Liquide, 12.10.2010).

O acolhimento do CEE e sobretudo a sua prática funcionam, pois, "sobre carris" e este aspeto é igualmente relevante para que se considere que a eficácia do CEE se mede sobretudo para além dos aspetos meramente formais ditados pelo acordo:

Nós na Air Liquide tivemos uma adesão de 100\%. E nunca tive problemas nenhuns em deslocações, de acesso a informações, nada, nada, cinco estrelas. Na prática, funciona tudo muito bem, toda a informação que eu precise, para tudo o que eu tenho que transmitir aos colegas utilizo os meios da empresa (...) (Representante português no Bureau do CEE do Grupo Air Liquide, 12.10.2010).

\subsubsection{O papel (negocial) da comissão de trabalhadores}

Mesmo sem ter a visibilidade pública e exposição mediática que se pode atribuir à CT da Autoeuropa, é um facto que a CT da Air Liquide é vista também como a organização representativa de trabalhadores a quem parece ser reconhecida uma intervenção particular no domínio dos CEEs. Pelo menos no caso português, isso explica-se em parte pela reduzida presença sindical, situação contrastante com o que sucede nas outras filais do Grupo e, portanto, com os outros representantes do CEE:

Estou há trinta e três anos na Air Liquide. Neste momento sou mesmo dos mais velhos e pessoas com tanto tempo de casa como eu devemos ser para aí uns seis ou sete. O resto é tudo gente mais nova que veio. E nesta percentagem dos que vieram novos e dos que existem antigos se eu lhe disser que em 185 [da parte agro-industrial] teremos no máximo dez sindicalizados é o máximo (...). 
E em trinta membros de 16 países do Comité Europeu eu sou o único membro que pertence a uma Comissão de Trabalhadores. O resto é tudo sindicalistas! (...). Aqui o nível de sindicalizados é muito pequeno, quase inexistente, e não temos nenhum sindicalista na empresa. Eu sou sindicalizado mas não sou sindicalista (...). O que eu digo é que, em Portugal, no que diz respeito à Air Liquide, não existem sindicalistas e por isso os sindicatos não têm interferência rigorosamente nenhuma nas negociações que a Comissão de Trabalhadores todos os anos faz com a empresa (Representante português no Bureau do CEE do Grupo Air Liquide, 12.10.2010).

Por outro lado, de par com esta escassez de representatividade e de poder sindical, sobressai também uma imagem dos sindicatos que é pouco favorável à criação de consensos entre as partes laboral e patronal. Como foi salientado por Costa noutros lugares (Costa, 2004a: 236-238; 2004b: 192-194), embora não seja nos CEEs que se verifica a maior competitividade entre sindicatos com diferentes orientações políticas e ideológicas, essa questão não pode deixar de ser equacionada até porque, no caso português, CGTP e UGT atribuem diferentes prioridades aos CEEs.

Na secção inicial relativa ao "caso Air Liquide" tivemos ocasião de referir os domínios de intervenção e as estratégias do Grupo: a questão da inovação, das tecnologias de ponta, da empresa social, da empresa cidadã, do código de ética, do código de conduta, etc. Porém, quando entrevistámos o representante português no Bureau do CEE do Grupo Air Liquide questionámo-lo por que motivo, naquele quadro de grande abertura da empresa ao "social", o tema dos CEEs e a referência à questão do diálogo social com os trabalhadores e suas organizações não aparecia mencionado no site da empresa. ${ }^{74}$ Ora, para o representante entrevistado isso deve-se precisamente a um certo receio de uma cultura de protesto (associada à atuação sindical) da qual a empresa procura sempre resguardar-se:

\footnotetext{
${ }^{74}$ Não cremos que se trate de uma exceção pois o mesmo se constata quer no caso do Grupo VW e do Grupo BES, o que não surpreende pois a estruturação do site de ambos os Grupos é certamente da responsabilidade das respetivas administrações.
} 
Como sabe, tem havido bastantes greves em França por causa agora do aumento da idade da reforma, etc.. E estão lá membros da Air Liquide, e aparece a tarjeta da Air Liquide. Tanto quanto possível eles evitam levar algo a dizer "Air Liquide". E a empresa tem receio do papel dos ativistas nos outros países, porque são muito mais ativistas do que nós, porque os sindicatos é que definem os aumentos, na França, na Itália, na Alemanha, etc.. Aqui não, aqui é a Comissão de Trabalhadores, independentemente daquilo que os sindicatos pensam... (Representante português no Bureau do CEE do Grupo Air Liquide, 12.10.2010).

Assim sendo, num contexto em que a crítica à atuação dos sindicatos emerge como dominante (no caso português pelo menos) - tanto mais que a ideia de luta e competição associada aos sindicatos é um entrave à promoção de uma cultura negocial no quadro dos CEEs -, a CT destaca-se, pois, como facilitadora de consensos e instigadora de paz social. A CT é, na verdade, menos propensa a "criar ondas" ou a levantar problemas que possam inclusive interferir com a imagem do Grupo Air Liquide que, como se referiu acima, se pretende preservar:

Nós aqui, na Air Liquide em Portugal, temos tido melhores aumentos por via dos negociadores da Comissão de Trabalhadores, com algum orgulho também lhe digo isso, do que se tivesse que ir pelo sindicato. Porque o sindicato teima e pimba e parte e não aceitamos e não sei que mais. E nós, por via do nosso diálogo e empenho temos conseguido bons aumentos (...). E digo-lhe mais: em França, essencialmente em França, estão a retomar um bocado a forma de negociação que é adotada em Portugal. Está a ver? É assim, aquilo que eu lhe digo é que eu prefiro levar algo do que levar zero. Eu posso-lhe dar um exemplo: o ano passado eles queriam negociar três por cento, em França. E os sindicatos disseram que queriam três zero um. E eles disseram que por um por cento não aceitavam, não negociavam. Ou seja, perdeu toda a gente por causa da teimosia dos sindicatos em zero vírgula um por cento. Era preferivel ter levado três por cento, na minha opinião do que levar zero (Representante português no Bureau do CEE do Grupo Air Liquide, 12.10.2010). 
Ora, de par com esta intransigência negocial atribuída aos sindicatos, constata-se ainda, no caso da Air Liquide Portugal, um trabalho de maturação negocial consolidado por iniciativa e envolvimento da CT. E se, por um lado, se regista uma fraca apetência para encontrar seguidores, i.e., trabalhadores disponíveis para ocuparem lugares de representação no seio da CT, por outro, como ficou expresso pelo representante português no Bureau do CEE do Grupo Air Liquide, conquistaram-se direitos (por via da CT) que agora também não devem nem podem ser questionados:

Eu já estou na Comissão de Trabalhadores desde 1981, entrei em 1978. Estou desde 1981, e não há ninguém nesta empresa que queira assumir uma nova lista. Eu posso-lhe dizer que nós fizemos eleições o ano passado e, claro, propusemos que aparecessem listas. Não apareceu rigorosamente ninguém. Tivemos que voltar a reiniciar o processo e fazermos uma lista com os que estavam. Porque é assim: nós não vamos entregar isto, passo a expressão, ao juiz. Estão aqui muitas gerações que lutaram por direitos e não vamos entregar isto de mão beijada (Representante português no Bureau do CEE do Grupo Air Liquide, 12.10.2010).

O papel negocial da CT (assumido em nome da valorização do diálogo e não da assunção de posturas assertivas e intransigentes) afigura-se, pois, também como algo que importa preservar.

\subsubsection{Um CEE imune à crise internacional?}

Em contexto de retração económica internacional, abordar o tema da "saúde financeira" do grupo tornou-se incontornável, tanto mais que a vida de um CEE também depende de recursos disponibilizados pela Air Liquide para o seu funcionamento. Mesmo que o representante entrevistado tenha sido algo cauteloso na abordagem da performance financeira do grupo -, o que a nosso ver se explica sobretudo por entender que tal entraria em explicações que tocam o tema das "oportunidades de negócios" e, como tal, poderiam interferir com o sigilo profissional que está 
obrigado a respeitar -, o que é facto é que a situação relatada é bastante favorável. Ora, sendo a situação muito boa do ponto de vista financeiro, não é de estranhar que possam daí advir consequências positivas do ponto de vista social, o que abrange a atuação do CEE:

Somos uma empresa que face à situação económica do país temos uma situação muito boa, estamos com muitos bons resultados. E digo isto com algum orgulho. Portanto, nunca tivemos necessidade de fazer greves, de tomar posições de força, etc., aqui e acolá. A empresa ouve um bocado, escuta-nos bem, a Comissão de Trabalhadores, dá-nos a informação de que precisamos sempre que solicitamos. Procura cumprir sempre a lei, nunca quer estar acima da lei, não quer problemas ... (...) Neste momento o Grupo Air Liquide pretende crescer até ao final do ano, a nível mundial, oito a dez por cento. No primeiro semestre já vai em 13,3\%. E estamos em crise! (...) E no Comité Europeu discutimos o Grupo no seu todo: resultados dos países emergentes, dos países de Leste e a Europa, etc., da Ásia, da África, de todos estes países. E veja bem, um grupo como este, numa situação de crise, a crescer 13,3\%! Isto é excelente! (Representante português no Bureau do CEE do Grupo Air Liquide, 12.10.2010).

Informação disponível no site do Grupo Air Liquide (consultada em meados de 2013) permite confirmar (em 2010 e 2011) o trajeto favorável do Grupo: em 2010 o Grupo Air Liquide faturou 13,5 mil milhões de euros, tendo mais de $80 \%$ desse valor sido gerado fora da França (sede do Grupo). Aliás, como assinalava Benoît Potier, presidente do Grupo, no Relatório Anual de 2010, "os resultados de 2010 ilustram a saída da crise e constituem um bom augúrio quanto à manutenção do crescimento nos próximos anos e à alimentação da nossa ambição"75. Estes números - melhorados em 2011 (ano em que o Grupo faturou 14,5 mil milhões de euros, tendo igualmente $80 \%$ desse valor sido gerado fora da França) e 2012 (ano em que o Grupo faturou 15,3 mil milhões de euros) - apontam, assim, no sentido da confirmação do Grupo Air Liquide como líder

75 http://rapportannuel.airliquide.com/pdf/Air_Liquide_Rapport_Annuel_2010_FR.pdf, p. 5. 
mundial dos gases para a indústria, a saúde e o ambiente, como de resto consta da página oficial do Grupo. ${ }^{76}$ Aliás, esta capacidade da Air Liquide rentabilizar todo o tipo de investimentos não deixa igualmente de ser enfatizada pelo representante português no CEE. E este, além disso, aproveita para salientar que, por via da sua participação no CEE (Bureau), tem acesso também a informação privilegiada sobre o desempenho do Grupo:

Os gases estão em todas as atividades. Em tudo o que você possa imaginar os gases estão presentes e cada vez mais. Pela empresa que nós somos, nós vendemos empresas e compramos empresas que possam trazer maior valor acrescentado. Não somos nós, em Portugal, é a França que decide. Então há uma empresa num local qualquer da Europa [havia alemãs, em Itália, por exemplo, a maioria dos meus colegas portugueses não conbece isso e eu por estar no Comité Europeu conheço muito melhor o Grupo do que até se calhar Portugal]... e que são empresas que o Grupo compra porque trazem mais valor acrescentado para a nossa atividade. Principalmente nos bospitais, na higiene e saúde hospitalar, fornecemos gases, etc. É importante que também consigamos ter alguém ligado à área da desinfeção, à área da manutenção, etc.. E então compramos essas empresas. Quando elas se tornam, não digo obsoletas mas mais pesadas e os resultados não são aquilo que esperavam, a empresa vende, vende a atividade...(Representante português no Bureau do CEE do Grupo Air Liquide, 12.10.2010).

Mas de par com o desempenho económico de excelência do Grupo é importante reforçar que esse mesmo desempenho é quase sempre acompanhado de uma estratégia de gestão/proteção de imagem por parte do Grupo e, consequentemente, o CEE é levado também a valorizar a opção por estratégias mais conciliatórias e menos conflituais:

Como calcula, uma multinacional destas não lhe interessa vir nos jornais hoje e amanhã. "Vai haver uma greve ou os trabalhadores não sei o quê...".

76 Consultem-se estes e outros dados em http://www.airliquide.com/en/company/who-we-are/financial-results.html. 
Não querem isso. É também para nós uma mais-valia em termos de negociação, porque eles, não querendo problemas, é muito mais fácil para nós também conseguirmos os nossos objetivos (...). Vale a pena repetir, a empresa não quer muito que apareça nos jornais o nome deles, do Grupo Air Liquide, e como tal normalmente eles cedem um bocado quando a gente ameaça que vamos ter que tomar atitudes mais drásticas inclusive recorrer à imprensa. Eles dizem, "calma lá, vamos discutir e tal". Este é sempre o argumento da empresa, da direção, a nível mundial e aqui em Portugal é a mesma coisa (Representante português no Bureau do CEE do Grupo Air Liquide, 12.10.2010).

\subsubsection{Conquistas do CEE}

Na secção anterior já foi mencionada uma das conquistas para a "parte laboral" decorrente do papel dos CEE, a saber, o conhecimento que se adquire sobre o Grupo económico em geral e sobre os seus desempenhos relacionados com as necessidades de gases em múltiplos domínios de atividade. Por outro lado, é importante acentuar a ideia de que os resultados do CEE e as conquistas que lhes estão associadas prendem-se inevitavelmente com o ponto anterior, relativo ao desafogo financeiro do Grupo Air Liquide. Nesse sentido, poder-se-á tomar como válida, não só para este CEE como para os CEEs em geral, a seguinte correlação: o "lado social” inerente aos CEEs varia na razão direta do desafogo financeiro das multinacionais, ou pelo menos este desafogo contribui para o tornar mais visível. Além de resultarem do desafogo económico do Grupo, as conquistas do CEE dependem também da atuação do representante no CEE (Bureau), designadamente da adoção de uma postura negocial que, por sinal, é "importada" ou "copiada" da postura que subjaz (como se referiu acima) à atuação da CT:

O que se conseguiu por via do CEE não se teria conseguido se não estivéssemos no CEE. Ou seja, isto foi algo que, pela minha dedicação e pelo facto de eu estar na Comissão de Trabalhadores... eu não sou barulbento mas o que tenho a dizer digo, não peço licença. Educadamente. E trouxe mais valor 
acrescentado. E as pessoas incentivam-me, por isso, a estar no CEE... (Representante português no Bureau do CEE do Grupo Air Liquide, 12.10.2010).

Para lidar com os (escassos) problemas que possam surgir no dia-a-dia - tais como desemprego, despedimentos, salários que não são atualizados, ambiente, segurança, tudo o que envolva as áreas que possam por si só criar mal-estar entre os trabalhadores ou degenerar em conflitos -, uma das iniciativas levadas a cabo pelo Bureau da Air Liquide foi a criação de um "jornal de crise". Tal "jornal” pode funcionar por "antecipação", isto é, como sinal de alerta para a eventual ocorrência de tais problemas, bem como enquanto instrumento de denúncia da ocorrência de problemas:

Nós tínhamos um jornal que se chamava o "Jornal de Crise" que foi criado a partir de uma ideia do Bureau. Quando todos os países presentes no Comité Europeu indicam a existência de situações graves que possam ocorrer em cada país devem transmitir ao Bureau e nós fazemos um jornalzinho pequenino...(...) Com um jornal de crise os membros representantes no plenário dos países presentes no Comité de Empresas do Grupo Air Liquide assumiram a responsabilidade de, quando sentirem que qualquer coisa que se vai passar num país, uma deslocalização, um despedimento coletivo, etc., informarem o CEE e comunicarem ao Bureau. E o próprio Bureau depois desencadeia ações junto da Direção, ao nível mundial, em Paris, para sabermos o que é que se passa e tentar evitar, se for caso disso, que as coisas ocorram (Representante português no Bureau do CEE do Grupo Air Liquide, 12.10.2010).

Por outro lado, o CEE em si mesmo, na sua prática, tem funcionado como instrumento de pressão "secundária" (complementar da pressão nacional "primária”) quer para garantir segurança aos trabalhadores, quer para evitar (ou criar condições para evitar) a ocorrência de despedimentos:

Quando, na nossa atividade aqui em Portugal, existiram situações que estavam menos bem, o que eu disse, enquanto membro do Bureau, foi: "eu não concordo com isto e quando for a Paris vou denunciar isso no Comité Europeu, porque eu não estou lá para dizer, sim senbor, não estou lá só para 
dizer sim, estou para dizer aquilo que eu penso, aquilo que está menos bem no meu país e quero que seja alterado". Nós tivemos aqui um problema de segurança que podia degenerar numa falta de segurança no país. Eu tenho 33 de empresa, nunca cá tinha estado o Diretor Mundial da Segurança e ele veio cá. Ele perguntou-me: "o que é que está a precisar, o que é que se está a passar Jorge?” Eu disse: "não, só vos estou a dizer que há problemas em Portugal, eu não sou denunciante, nem vou denunciar pessoas. Há problemas e graves que podem degenerar num conflito grave em termos de segurança, e sendo essa a nossa preocupação número um do Grupo é bom que tomem providências". E eles tomaram! Vieram cá, o assunto foi resolvido, mudam-se as pessoas, pacífico! (...). Ou seja, o caso tinha pessoas em causa, e também foram alteradas as pessoas. Por via do Comité Europeu, porque se fosse só Portugal não acontecia nada. Mas como foram, passo a expressão, ameaçados quando eu disse: "eu vou chegar ao Comité Europeu e dizer o que é que se passa", então aqui as pessoas disseram: "eh pá, temos que ter cuidado, o gajo vai lá fora e pumba, vai botar a boca no trombone". E então, isso foi uma forma (eu noto isso), uma mais valia de agilizar um ou outro conflito que possa existir aqui em Portugal, se bem que raramente existam. Mas quando existem a utilização do Comité Europeu faz com que eles se acalmem mais (Representante português no Bureau do CEE do Grupo Air Liquide, 12.10.2010).

É importante fazer notar que este CEE (como os CEEs, na sua grande maioria) não dispõem de poderes de veto para impedir uma decisão que a administração da empresa possa ter convictamente decido ir implementar. Nesse sentido, é compreensível que se registe alguma ambiguidade na relação entre empresa e trabalhadores. Ou melhor, é necessário pôr alguma "água na fervura” na euforia em redor dos CEEs, pois se por um lado o CEE informa sempre antecipadamente antes de uma decisão, por outro deixa pouco espaço de manobra para que a mesma seja alterada:

Sim, conseguimos anular muitas das vezes situações de conflito que possam existir. Conseguimos renegociar coisas que à partida supostamente não iriam ocorrer... Conseguimos evitar despedimentos muitas das vezes. Conseguimos evitar vendas de empresas, conseguimos evitar processos disciplinares, conse- 
guimos melhorar a segurança e a eficácia aqui e acolá através de denúncia de situações nos mais diversos sítios (...). No nosso caso, se tiver que haver deslocalização como já aconteceu em um ou dois casos a empresa comunica atempadamente antes de isso acontecer. Depois, não adianta nada o Comité Europeu ir manifestar-se. Pode dar a sua sugestão, pode comunicar entre todos mas a decisão está tomada e é irreversível. Mas comunicam, mas comunicam. Agora, vale o que vale, vale o que vale (...). Agora também é importante dizer que quando eles vendem empresas, atividades que têm (...) procura-se sempre que a empresa que compre garanta os anos de casa do trabalhador, sempre que possível os mesmos salários, as mesmas regalias, etc. Também não vendem a uma empresa qualquer (Representante português no Bureau do CEE do Grupo Air Liquide, 12.10.2010).

O "pau de dois bicos” deixado transparecer na citação anterior não belisca, todavia, os resultados do CEE. Já aqui se falou, recorde-se, em evitar despedimentos, em exercer pressão secundária por via do CEE para resolver problemas nacionais (como a segurança dos postos de trabalho) e tudo isso se traduz em conquistas. Ou, se quisermos, trata-se de ações que, pelo menos, vão no sentido de garantir o status quo dos trabalhadores do Grupo, facto que não pode ser desconsiderado, muito em especial em tempos de austeridade (mesmo que tais tempos adversos não pareçam propriamente ter perturbado a atividade do Grupo Air Liquide). Mas há outros importantes sinais de conquistas sociais associados ao CEE (designadamente com implicações para os trabalhadores em Portugal) que não podem deixar de ser mencionados - como um mês de salário adicional -, ainda que os mesmos não deixem de estar relacionados com a "boa saúde" financeira do Grupo Air Liquide:

Temos trazido mais valor acrescentado pelo facto de estarmos representados no Comité Europeu. E sobretudo quando há resultados no Grupo. Conseguiram-se coisas que havia lá fora e a que nós não tínhamos acesso em Portugal. Passámos a ter, por exemplo mais um mês de salário. Desde que o Grupo atinja os resultados... Quer dizer, significa que toda a gente aqui em Portugal tem os doze meses normais, o $13 .^{\circ}$ mês e o subsídio de férias. Passámos a ter mais 
um mês, por via dos resultados, coisa que os outros usufruíam e nós não. Ou seja, isto é algo que se nós não estivéssemos no Comité Europeu não sabíamos e nunca íamos usufruir...(Representante português no Bureau do CEE do Grupo Air Liquide, 12.10.2010).

São estas conquistas que, na opinião do represente português no bureau do CEE do Grupo Air Liquide, tornam plausível classificar a atuação deste CEE como de CEE "misto" entre os tipos ideais de CEE com melhores práticas: o CEE orientado para projetos e sobretudo o CEE participativo. $\mathrm{Na}$ verdade, a longa experiência do representante português permite-lhe situar o CEE numa via per mezzo entre o CEE orientado para projetos e o CEE de tipo participativo. Por um lado, no primeiro caso, porque o CEE se confirma como órgão que define e executa projetos baseados no desenvolvimento das suas estruturas internas de comunicação. Define as suas próprias tarefas (projetos), as quais é capaz de implementar independentemente da administração. O exemplo que aqui foi mencionado do "jornal de crise" é ilustrativo da recolha sistemática e da troca de informação relacionada com as condições (nacionais) de trabalho, padrões sociais, etc., dando origem à troca transnacional de informações entre representantes, a qual pode ser usada, por parte dos representantes de trabalhadores, como "moeda de troca" negocial com a administração central ou local da empresa.

Por outro lado, o CEE do Grupo Air Liquide é considerado participativo pelo seu representante português. O CEE de tipo participativo, recorde-se, tem por objetivo expandir o seu leque de atividades e de participação para além das atribuições normalmente associadas aos CEEs, no sentido de ser uma estrutura com poderes consultivos formalmente regulamentados, com capacidade de negociação e de propor iniciativas conjuntas com a administração. A via para se conseguirem acordos e posições conjuntas com a administração assenta, em geral, no campo dos temas que são consensuais para todos os intervenientes, os quais podem dar origem a projetos conjuntos ou acordos firmados. As negociações sobre temas "quentes", tais como horários de trabalho ou proteção no local de trabalho, exigem um conjunto complexo de requisitos relacionados com 
a constituição interna do CEE, constelações específicas de interesses (por parte do próprio CEE e da administração), e pressões para agir que podem implicar processos de troca. Mas a ideia de mobilização e envolvimento (num contexto cada vez mais internacional) é provavelmente o que mais sobressai da atuação do CEE do Grupo Air Liquide. Uma vez mais, nas palavras do experiente representante português no Bureau deste CEE: "há uma mobilização, eu diria que minimamente razoável, das pessoas. Eu, honestamente, estou satisfeito com o CEE do Grupo”.

\subsubsection{O CEE do Grupo BES}

Neste espaço dá-se conta do papel pioneiro do CEE do Grupo BES em multinacionais com sede em Portugal, bem como de alguns desenvolvimentos mais recentes no seu modus operandi. ${ }^{77}$

\subsubsection{Um CEE pioneiro em Portugal}

Em 2013, o CEE do Grupo BES78 era ainda o único CEE constituído numa multinacional com sede em Portugal. Vale a pena realçar aqui 3

77 À semelhança dos casos dos CEEs dos Grupos VW e Air liquide, realizou-se uma entrevista de fundo com o representante atual dos trabalhadores, que permitiu igualmente estabelecer pontos de comparação com entrevistas anteriores realizadas com o anterior coordenador do CEE, como por exemplo a disponibilizada em Costa e Araújo (2007b: 446-458).

78 No final de 2008, o Grupo Banco Espírito Santo empregava aproximadamente 5.000 trabalhadores em mais de 17 países, de quatro continentes. Cerca de 4.550 encontravam-se em Portugal e cerca de 450 no resto da Europa. O segundo país com maior número de trabalhadores era (e continua a ser) a Espanha, com cerca de 400 colaboradores. Assinala-se a forte presença ibérica, ainda que o CEE vá deixando de ser progressivamente só ibérico. Segundo o coordenador do Secretariado do CEE do Grupo BES (entrevista realizada em 12.10.2010), o BES tem mais de 6.000 trabalhadores e além dos 26 balcões que tem em Espanha (com cerca de 450 trabalhadores) conta também com uma maior presença em Inglaterra, com 39 trabalhadores. Um olhar mais recente (disponível em http://www.bes.pt/ SiteBES/cms.aspx?plg=ff39462a-2f21-406b-b968-dc7566c9c7c4 e consultado em 20.06.2013) menciona, no entanto, que em 2012 o Grupo BES dispunha de 9.944 empregados. 
aspetos interrelacionados que ajudam a explicar o take-off do CEE, o seu funcionamento e alguns resultados ${ }^{79}$.

\subsection{As condições para o surgimento do CEE}

A possibilidade de formar um CEE foi primeiramente sugerida pela Comissão de Trabalhadores (mandato de 2000 a 2003) que, numa concertação de esforços que mobilizou sindicatos portugueses (Sindicatos dos Bancários do Centro, do Norte e do Sul e Ilhas, e Sindicato Nacional dos Quadros e Técnicos Bancários) e sindicatos espanhóis (Federação dos Trabalhadores Independentes, Federação dos Serviços Financeiros e Administrativos das Comisiones Obreras, e Federação dos Serviços da Unión General de Trabajadores), impulsionou a formação de um Grupo Especial de Negociação (GEN) para encetar negociações com a administração.

De entre as condições de partida que mais influenciaram a constituição do Procedimento de Informação e Consulta (PIC), em julho de 2003, e que viria mais tarde a ser formalizado num CEE (em março de 2005), destacam-se as seguintes:

- O bom relacionamento inicial entre a Comissão de Trabalhadores (CT) do Grupo BES (em exercício aquando do início das negociações) e os sindicatos portugueses. Este bom relacionamento deveu-se ao facto de existirem representantes que eram simultaneamente membros da CT e de sindicatos. ${ }^{80}$ Neste contexto, a importância das relações pessoais e de confiança entre os diversos atores constituiu

79 Para uma análise mais detalhada do papel pioneiro deste CEE, cf. Costa e Araújo (2008; 2009: 53-61).

${ }^{80}$ A relação entre a CT - que tomou posse na tarde da celebração do PIC (16.07.2003) e cujo mandato vigorou até outubro de 2006 - e o CEE viria, porém, a assumir novos contornos, com a CT a recusar-se nomear os cinco membros para o CEE que haviam sido acordados aquando da negociação do acordo (Conselho de Empresa Europeu do Grupo BES, 2005: 5). Esta situação manteve-se, de resto, inalterada após a eleição (outubro de 2006) da nova CT, só tendo sido reparada na sequência da legalização do CEE do Grupo BES no Ministério do Trabalho e da Solidariedade Social no final de 2008 (conforme se reforça adiante). 
um requisito fundamental para o estabelecimento e posterior funcionamento do CEE. Tal como outras instituições, também os CEEs se encontram dependentes do protagonismo individual de alguns atores chave. Como afirmava o presidente do CEE da Reckitt Benckisser, a aprendizagem sobre os CEEs significa também a aprendizagem sobre a arte da diplomacia (Namuth, 2005).

- O bom relacionamento entre a CT do Grupo BES (em exercício aquando do início das negociações) e os sindicatos espanbóis. O parceiro espanhol revelou-se decisivo quer no processo de constituição do CEE, quer porque em resultado da alteração de estratégia do Grupo BES em Espanha (na sequência da aquisição do Banco Inversión) contribuiu para conferir ao CEE maior protagonismo e dinamismo. Com efeito, de acordo com um representante português do CEE do GBES, o sucesso da aquisição do Banco Inversión foi fundamental para transformar o PIC em CEE, convertendo, assim, o CEE numa estrutura mais ibérica do que europeia; 81

- Um bom relacionamento com a administração. As negociações tiveram início entre o Grupo Especial de Negociação e os representantes da administração, tendo conduzido à assinatura, a 16 de julho de 2003 , de um acordo para a constituição de um Procedimento de Informação e Consulta (PIC). A opção por um procedimento de informação e consulta, ao invés de um CEE, foi sugerida pelo representante da administração que, tendo em conta a inexistência de experiências em multinacionais com sede em Portugal e a nível setorial, conside-

81 Não obstante esta iberização poder estar hoje um pouco mais disfarçada (como se sugeriu acima), a importância do parceiro espanhol reflete-se, desde logo, na letra do acordo, nomeadamente ao nível da informação e consulta, definindo o acordo as matérias transnacionais como aquelas que dizem respeito ao Grupo BES no seu conjunto ou, no mínimo, às empresas do Grupo com sede em Portugal e em Espanha (como pode ler-se quer no art. $15^{\circ}, 2$ do acordo do CEE de 2005, quer na versão do acordo de 2008). A Espanha aparece como o único país comum a todas as multinacionais portuguesas onde estas detêm operações, facto que evidencia a presença de relações económicas de proximidade e uma iberização da integração europeia. É neste registo, aliás, que se pode situar a afirmação proferida há mais de uma década por Reis e Baganha (2001: 21), segundo a qual "numa época em que o termo emblemático é globalização, o espaço económico do relacionamento externo de [Portugal] é cada vez mais europeu do que mundial e é cada vez mais ibérico do que europeu". 
rou prudente que, pelo menos inicialmente, a estrutura assumisse a designação formal de um PIC, embora na prática funcionasse efetivamente como um CEE, como sucedeu em 30 de março de 2005, conforme o quadro 41.82

\section{QUADro 41 - Acordos originais do Procedimento de Informação e Consulta e do Conselho de Empresa Europeu do Grupo Banco Espírito Santo}

\begin{tabular}{|c|c|c|}
\hline & $\begin{array}{l}\text { Procedimento de } \\
\text { Informação e Consulta } \\
\text { (PIC) }\end{array}$ & $\begin{array}{l}\text { Conselho de Empresa Europeu } \\
\text { (CEE) }\end{array}$ \\
\hline Tipo de acordo & \multicolumn{2}{|c|}{ Artigo $6 .^{\circ}$} \\
\hline Signatários & GEN e Direção Central & Membros do CEE e Direção Central \\
\hline Data & 16 de julho 2003 & 30 de março 2005 \\
\hline Legislação aplicável & \multicolumn{2}{|c|}{ Legislação Portuguesa } \\
\hline Alcance geográfico & \multicolumn{2}{|c|}{$\begin{array}{l}\text { Abrande todas as empresas controladas pelo BES com sede nos } \\
\text { Estados-membros da UE. Presentemente, abrange o Banco Espí- } \\
\text { rito Santo, S.A. (BES) com sede em Portugal e o Banco Espírito } \\
\text { Santo, S.A. (BESSA) sediado em Espanha. }\end{array}$} \\
\hline Duração do acordo & \multicolumn{2}{|c|}{$\begin{array}{l}\text { Quatro anos renovados por mais quatro se o acordo não for de- } \\
\text { nunciado por qualquer uma das partes com uma antecedência } \\
\text { de seis meses. }\end{array}$} \\
\hline Composição & \multicolumn{2}{|c|}{ Representantes dos trabalhadores } \\
\hline Atribuição de lugares & \multicolumn{2}{|c|}{$\begin{array}{l}\text { - Dez representantes portugueses (5 lugares para a Comissão } \\
\text { de Trabalhadores; } 2 \text { lugares para o Sindicato dos Bancários do } \\
\text { Sul e Ilhas, } 1 \text { lugar para o Sindicato dos Bancários do Norte, } 1 \\
\text { lugar para o Sindicato dos Bancários do Centro, e } 1 \text { lugar para } \\
\text { o Sindicato Nacional de Quadros e Técnicos Bancários). } \\
\text { - Um representante espanhol (em representação de diversos sin- } \\
\text { dicatos). } \\
\text { - Os representantes serão em número de } 11 \text {. }\end{array}$} \\
\hline $\begin{array}{l}\text { Eleição/nomeação dos } \\
\text { representantes dos } \\
\text { trabalhadores }\end{array}$ & \multicolumn{2}{|c|}{$\begin{array}{l}\text { Os representantes portugueses são designados/eleitos de entre } \\
\text { trabalhadores do GBES no ativo, de acordo com o estipulado na } \\
\text { lei aplicável. Os representantes espanhóis são designados/eleitos } \\
\text { de entre trabalhadores do GBES no ativo, de acordo com as dis- } \\
\text { posições legais e regulamentares do respetivo Estado-membro. }\end{array}$} \\
\hline
\end{tabular}

82 Do quadro 41 não constam as ligeiras alterações decorrentes do acordo do CEE revisto em 2008. Adiante são melhor fundamentadas essas alterações, as quais ocorreram no quadro de uma legalização do CEE no então Ministério do Trabalho e da Solidariedade Social. Entre outros pontos, implicam um upgrade das matérias que são sempre objeto de informação e consulta dos trabalhadores e um reforço dos direitos de reunião com a direção central e sem a direção central. 


\begin{tabular}{|c|c|c|}
\hline & $\begin{array}{l}\text { Procedimento de } \\
\text { Informação e Consulta } \\
\text { (PIC) }\end{array}$ & $\begin{array}{l}\text { Conselho de Empresa Europeu } \\
\text { (CEE) }\end{array}$ \\
\hline $\begin{array}{l}\text { Proteção dos } \\
\text { representantes dos } \\
\text { trabalhadores }\end{array}$ & \multicolumn{2}{|c|}{ Prevista } \\
\hline Duração do mandato & \multicolumn{2}{|c|}{ Quatro anos } \\
\hline Formação & \multicolumn{2}{|c|}{ Não prevista } \\
\hline Competências & \multicolumn{2}{|c|}{$\begin{array}{l}\text { Os representantes têm o direito de ser informados e consultados } \\
\text { pela Direção Central, em geral, sobre todas as matérias transna- } \\
\text { cionais suscetíveis de afetar consideravelmente os interesses dos } \\
\text { trabalhadores. São consideradas matérias transnacionais todas as } \\
\text { que dizem respeito ao conjunto do GBES ou, no mínimo, às em- } \\
\text { presas com sede em Portugal e em Espanha }\end{array}$} \\
\hline $\begin{array}{l}\text { Questões objeto de } \\
\text { informação e consulta }\end{array}$ & \multicolumn{2}{|c|}{$\begin{array}{l}\text { - Mudança nas instalações que implique transferências de locais } \\
\text { de trabalho; } \\
\text { - Encerramento de empresas ou estabelecimentos; } \\
\text { - Despedimento coletivo; } \\
\text { - Política de pessoal. }\end{array}$} \\
\hline $\begin{array}{l}\text { Oportunidade da } \\
\text { informação e consulta }\end{array}$ & \multicolumn{2}{|c|}{ Inexistência de compromisso } \\
\hline Confidencialidade & \multicolumn{2}{|c|}{$\begin{array}{l}\text { Representantes não devem revelar a terceiros as informações re- } \\
\text { cebidas com expressa reserva de confidencialidade nem as infor- } \\
\text { mações sujeitas pela sua natureza ao dever de sigilo profissional. } \\
\text { Dever de sigilo perdura para além do local em que os obrigados } \\
\text { se encontrem durante e após os respetivos mandatos e da cessa- } \\
\text { ção das suas funções. }\end{array}$} \\
\hline $\begin{array}{l}\text { Recusa em prestar } \\
\text { informação }\end{array}$ & \multicolumn{2}{|c|}{$\begin{array}{l}\text { A Direção Central reserva-se o direito de recusar prestar informa- } \\
\text { ção que, por lei ou regulamento, seja considerada confidencial ou } \\
\text { privilegiada. Decisão da Direção Central poderá ser impugnada } \\
\text { judicialmente pelos representantes dos trabalhadores. }\end{array}$} \\
\hline $\begin{array}{l}\text { Recursos materiais e } \\
\text { financeiros }\end{array}$ & \multicolumn{2}{|c|}{$\begin{array}{l}\text { Em outubro de cada ano, os representantes dos trabalhadores } \\
\text { apresentarão à Direção Central uma proposta de orçamento para } \\
\text { o seu funcionamento. A direção Central suportará todas as des- } \\
\text { pesas, devidamente orçamentadas, referentes à organização, fun- } \\
\text { cionamento, informação e efetivação de reuniões, bem como as } \\
\text { referentes às eventuais deslocações e estadas dos representantes. }\end{array}$} \\
\hline Secretariado & $\begin{array}{l}\text { Quando da sua primeira } \\
\text { reunião, os representantes } \\
\text { elegerão entre si um Secre- } \\
\text { tariado. }\end{array}$ & $\begin{array}{l}\text { Na primeira reunião do CEE com a } \\
\text { Direção Central (1 de março 2006) } \\
\text { foi formado um Secretariado com- } \\
\text { posto por três membros: coordena- } \\
\text { ção, administração e finanças. }\end{array}$ \\
\hline $\begin{array}{l}\text { Número de reuniões/ano } \\
\text { sem Direção Central }\end{array}$ & \multicolumn{2}{|c|}{$\begin{array}{l}\text { Os representantes podem reunir até quatro vezes ao ano, desde } \\
\text { que em território nacional. }\end{array}$} \\
\hline $\begin{array}{l}\text { Número de reuniões/ano } \\
\text { com Direção Central }\end{array}$ & \multicolumn{2}{|c|}{$\begin{array}{l}\text { Os representantes podem reunir uma vez por ano com a Direção } \\
\text { Central. }\end{array}$} \\
\hline
\end{tabular}




\begin{tabular}{|c|c|c|}
\hline & $\begin{array}{l}\text { Procedimento de } \\
\text { Informação e Consulta } \\
\text { (PIC) }\end{array}$ & $\begin{array}{l}\text { Conselho de Empresa Europeu } \\
\text { (CEE) }\end{array}$ \\
\hline Reuniões extraordinárias & \multicolumn{2}{|c|}{ Previstas } \\
\hline Reuniões preparatórias & \multicolumn{2}{|c|}{$\begin{array}{l}\text { Representantes dos trabalhadores têm o direito a reunir no dia } \\
\text { anterior a qualquer reunião a efetuar com a Direção Central. }\end{array}$} \\
\hline Reuniões posteriores & \multicolumn{2}{|c|}{ Não previstas } \\
\hline Agenda & \multicolumn{2}{|c|}{$\begin{array}{l}\text { Deve estar disponível a ambas as partes num prazo de } 15 \text { dias } \\
\text { previamente à reunião anual entre representantes dos trabalha- } \\
\text { dores e Direção Central. }\end{array}$} \\
\hline Difusão da informação & \multicolumn{2}{|c|}{$\begin{array}{l}\text { Os representantes dos trabalhadores no CEE devem informar os } \\
\text { representantes dos trabalhadores das empresas do GBES ou, na } \\
\text { sua falta, os trabalhadores sobre as informações recebidas e os } \\
\text { resultados das consultas realizadas. }\end{array}$} \\
\hline Língua de trabalho & \multicolumn{2}{|c|}{ Portuguesa } \\
\hline Tradução & \multicolumn{2}{|c|}{ Considerada desnecessária } \\
\hline Peritos & \multicolumn{2}{|c|}{ Não previstos } \\
\hline
\end{tabular}

Fonte: Costa e Araújo (2009: 222-223)

\subsection{O dinamismo do CEE}

De entre as principais características que conferem dinamismo ao CEE do Grupo BES, podem destacar-se as seguintes:

- A ação do CEE do Grupo BES para além das "fronteiras rígidas» do acordo. Esta é uma das características mais marcantes do funcionamento do CEE. Se estivesse limitado ao acordo, o CEE não teria tido a possibilidade de realizar o número avultado de reuniões com o representante da administração do Grupo bem como deslocações às representações do Grupo no estrangeiro;

- Uma ação do CEE pró-ativa, traduzida, por exemplo, na inclusão na agenda das reuniões entre representantes dos trabalhadores e da administração de tópicos relevantes quer para os trabalhadores, quer para a administração. Um conhecimento aprofundado das atividades e estratégias do Grupo revela-se, nessa medida, fundamental;

- A maximização das redes e contactos informais que, combinados com deslocações às sucursais nacionais e internacionais, garantem 
o acesso a informação de qualidade, credível, na base da qual se pode sustentar a ação do CEE;

- A capitalização das relações com outros órgãos de representação dos trabalhadores, nomeadamente os sindicatos;

- Além de decisiva para o surgimento do CEE, a ocupação simultânea de cargos de responsabilidade em diversos órgãos de representação dos trabalhadores contribuiu também para o dinamismo do CEE. Esta pertença simultânea exige, porém, uma gestão equilibrada por parte dos representantes desses papéis institucionais, de modo a que não se verifiquem nem interferências, nem duplicações na sua ação; - A experiência acumulada dos membros do CEE quer quanto ao funcionamento da estrutura, quer em matéria de capital relacional que, por via da participação nesse órgão, vão adquirindo;

- As qualificações dos membros do CEE em geral e o domínio de línguas estrangeiras, em particular;

- A possibilidade dos representantes poderem dedicar-se ao CEE a tempo inteiro.

\subsection{Resultados alcançados}

As principais questões em que o CEE do Grupo BES produziu impactos positivos foram as seguintes:

- O impacto provocado pelo pioneirismo do CEE do BES, que por sinal continua a ser o único CEE constituído numa empresa com sede em Portugal;

- A aquisição de uma perspetiva macro das atividades do Grupo, ou seja, das "grandes questões" com impacto efetivo nos interesses dos trabalhadores;

- O papel de mediação que o CEE do BES passou a exercer entre a administração e as organizações de trabalhadores portuguesas e estrangeiras, em especial nas operações suscetíveis de afetar os interesses dos trabalhadores (fusões, aquisições, etc.), como foi o caso, em 2004, da primeira "prova de fogo" associada à aquisição 
do Banco Inversión ou a venda de agências ao Banco Simeón e à consequente necessidade de assegurar a manutenção de postos de trabalho em resultado desse processo;

- O feedback positivo transmitido aos membros do CEE por parte dos trabalhadores do BES.

- A difusão dos seus resultados práticos através de um Boletim Informativo especificamente criado com esse propósito;

- O feedback positivo recebido por parte dos colegas espanhóis.

\subsubsection{O CEE no presente: uma legalização que confirma uma prática}

Desde 2008 o CEE do BES passou a estar registado no Ministério do Trabalho e da Solidariedade Social ${ }^{83}$. Essa legalização veio confirmar a prática do CEE até então existente. Mas atentemos nalguns dos itens desse comportamento mais recente do CEE.

\subsection{Legalizar para reforçar a legitimidade do CEE}

Como já ficou dito, o CEE do Grupo BES começou por ser um PIC (em 2003) e consagrou-se como CEE em 2005. O CEE sempre funcionou com plena legitimidade, não obstante, como também foi referido, apenas 6 elementos (em 11) terem de início ocupado o lugar neste CEE. A não ocupação de lugares por parte dos representantes da CT deveu-se, segundo o ex-coordenador do CEE, a motivações de ordem político-partidária (i.e., a orientações partidárias distintas entre os sindicatos e a CT do CEE do Grupo BES). A legalização do CEE terá, entretanto, superado esse défice de representatividade do CEE, que não de legitimidade (pois esse défice não existia uma vez que a maioria havia ocupado o lugar no CEE).

83 Na sequência da formação do XIX Governo Constitucional, liderado por Pedro Passos Coelho, a "solidariedade social" foi incorporada no Ministério da Solidariedade e Segurança Social, ao passo que o "trabalho" ficou situado no âmbito do Ministério da Economia e Emprego. 
Como é referido no Boletim Informativo do CEE do Grupo BES (edição de outubro de 2008), na sequência de 8 meses de trabalho (entre deslocações ao Ministério do Trabalho e da Solidariedade Social, repartição de finanças e registo nacional de pessoas coletivas, bem como de entrevistas com variados interlocutores) viria a proceder-se à legalização do CEE em 4 de setembro de 2008. Assim, "hoje os trabalhadores do Grupo BES, S.A. já têm uma organização de nível europeu, que se rege por legislação europeia, para os defender e representar quer trabalhem em Portugal continental, Madeira, Açores, Espanha ou qualquer país da Europa" (CEE do Grupo BES, 2008: 3).

Mas este processo de legalização terá pesado também na decisão dos representantes eleitos por via da CT ocuparem os lugares que lhes estavam destinados desde a primeira hora:

Nunca tinham tomado posse. Nesse sentido, conseguimos que a comissão de trabalhadores indicasse os seus elementos. Estamos a funcionar com onze elementos, cinco dos sindicatos, de todos os sindicatos do setor, um dos Quadros, um do Sindicato do Centro, um do Norte e dois do Sul. Além disso, um das Comissiones Obreras (que é o grande representante das Comissiones Obreras em Espanha) e os cinco elementos da Comissão de Trabalhadores. Houve um grande esforço e conseguimos meter essa representatividade de cada órgão, essa é uma questão nova que está aí, os cinco elementos da Comissão de Trabalhadores... (Coordenador do CEE do Grupo BES, 12.10.2010).

Quanto ao texto do acordo do CEE do grupo BES celebrado em 2008 (Grupo Banco Espírito Santo, 2008), o que se constata é que veio sobretudo reforçar o acordo já existente (embora não registado no Ministério do Trabalho e da Solidariedade Social) e reproduzido acima: "Muito pouca coisa mudou. Praticamente é um decalque do antigo. Só uma ou outra coisa de pormenor, mas são coisas de pormenor" (Coordenador do CEE do Grupo BES, 12.10.2010). Assinale-se, no entanto, algum upgrade no texto do acordo mais recente, facto que lhe confere uma optimização de procedimentos. Por um lado, no que concerne às matérias que são sempre objeto de informação e consulta dos trabalhadores (artigo $15 .^{\circ}$, 
n. ${ }^{\circ}$ 3), constata-se que além das que já constavam do acordo de 2005 (mudança nas instalações que implique transferências de locais de trabalho; encerramento de empresas ou estabelecimentos; despedimento coletivo; e política de pessoal) são adicionadas mais duas: a transmissão de estabelecimento e as políticas salariais. Esta última é mesmo uma questão rara nas reuniões dos CEEs, pois a vocação dos CEEs não passa, em regra, por conceder espaço às políticas salariais.

Dois outros sinais de melhoria do acordo do CEE do Grupo BES no sentido de um reforço da capacidade de participação prendem-se com o direito de reunião com a direção central (artigo $17 .^{\circ}$ ) e sem a direção central (artigo $18 .^{\circ}$ ). Na verdade, o ponto 1 do artigo $17 .^{\circ}$ prevê que os representantes possam reunir com a administração central uma vez por semestre (ou seja, duas vezes por ano), ao passo que no anterior acordo estava apenas prevista uma reunião anual. Porém, a prática pode superar claramente esta periodicidade, pois "de dois em dois meses temos uma reunião com a administração central" (Coordenador do CEE do Grupo BES, 12.10.2010), ou seja, três vezes mais do que está previsto formalmente no acordo. Por outro lado, as próprias reuniões do CEE sem a administração central estão formalmente melhor salvaguardadas no texto do acordo em vigor, pois nos termos do ponto 1 do artigo $18 .^{\circ}$ os representantes reúnem até 6 vezes por ano (enquanto que no acordo anterior podiam reunir até 4 vezes por ano).

\subsection{O processo de revisão da Diretiva}

O processo de revisão da Diretiva é visto de forma muito soft. Por um lado, tratou-se de um passo há muito ansiado e saudado:

Saúdo efusivamente o acordo político que o Parlamento Europeu "impôs" à Comissão Europeia, em sede de diretiva sobre os Conselhos de Empresa Europeus, estabelecendo critérios mais objetivos para os conceitos de "informação" e de "consulta" dos trabalhadores, ao mesmo tempo que claramente define como transnacionais todas as matérias que se refiram à globalidade da empresa ou do grupo de empresas em pelo menos dois Estados-Membros da União Europeia. 
De resto, já o Comité Económico e Social tinha emitido um parecer sobre esta matéria, sublinhando que a proposta da Comissão não era clara no que toca à regulamentação sobre uma articulação lógica e viável da representação entre os níveis nacional e europeu, e que as competências dos conselhos eram limitadas pela definição da sua esfera de competência transnacional. Há que clarificar a responsabilidade da direção empresarial no fornecimento de informação correta e regular aos representantes de trabalhadores aos níveis nacional e transnacional. Manter ou introduzir limiares ao estabelecimento de conselhos de empresa europeus não se coaduna com o direito fundamental dos trabalhadores a serem informados em tempo útil (Gomes, 2009: 3).

Por outro lado, não obstante a maior precisão conceptual, segundo o coordenador do CEE do Grupo BES, considera-se que a nova Diretiva 2009/38/CE ainda terá ficado aquém do esperado, o que significa que há um entendimento de que as mudanças foram escassas. Não obstante alguns passos importantes terem sido dados, "principalmente nas contra-ordenações por não cumprimento das diretivas dos países e na precisão da ideia de informação, ficou aquém das expectativas da CES, que geralmente negoceia esta situação, mas também da UNI Finance, onde os sindicatos dos bancários estão filiados” (entrevista, 12.10.2010).

\subsection{A relação entre atores e o papel "guia" dos sindicatos}

Dois tipos de relacionamentos (já anteriormente considerados decisivos para a criação do CEE) permanecem na ordem do dia. Um deles é o relacionamento com a administração. Com se refere no acordo de 2008 (artigo $4 .^{\circ}$ ), a direção central do Grupo BES e os representantes dos trabalhadores comprometem-se a cooperar e agir "sempre de boa fé no exercício dos direitos e no cumprimento dos deveres resultantes do acordo". O facto de o acordo e a prática concreta preverem um reforço das reuniões do CEE com a administração central é indicativo da proximidade com esta e inclusive de uma certa cumplicidade, a qual se traduz também numa troca frequente de informações: 
É importante o pulsar daquilo que os trabalhadores sentem. Acho que este feed-back é importantíssimo para a administração. Como sabe, certas questões nunca chegam às hierarquias, ao topo, e como nunca chegam ao topo o que nós escrevemos ali [no relatório das reuniões entre trabalhadores] é do conbecimento da administração do Banco. Quando reunimos, principalmente com o presidente da Comissão Executiva, que é o Dr. Ricardo Salgado, nós damos mais tópicos porque às vezes há coisas que nem sempre se podem escrever aí. Mas tudo sempre dentro do âmbito do CEE (Coordenador do CEE do Grupo BES, 12.10.2010).

O segundo tipo de relacionamento é entre os próprios trabalhadores, o qual pressupõe uma boa devolução da informação dos representantes aos representados (i.e., ao coletivo dos trabalhadores do Grupo BES). $\mathrm{E}$ isso tem sido feito, por exemplo, dando continuidade a uma prática existente (desde a criação do PIC e do CEE) que consistiu na elaboração de boletins informativos destinados a socializar a uma escala mais alargada o papel do CEE. Mas o relacionamento entre trabalhadores pode também "medir-se" pelo relacionamento entre os próprios representantes, no seio do CEE. E neste domínio acaba por ser incontornável a referência ao relacionamento com a CT, decorrente da referida ocupação de lugares no CEE do Grupo BES por parte dos seus representantes. Trata-se hoje certamente de uma relação mais pacificada, ainda que o coordenador do CEE do Grupo BES não deixe de realçar a maior apetência do sindicato (pelo qual ele próprio foi eleito) para lidar com as questões de dimensão internacional, ao contrário da CT, cuja atuação é mais local, nacional e de empresa:

Dos elementos que integraram e que integram o CEE, os sindicais têm uma visão muito mais ampla dos problemas que afligem todos os trabalhadores bancários, mais propriamente o setor financeiro. Nesse sentido deram e dão um novo ritmo, coisa que as comissões de trabalbadores não estão habituadas. As comissões de trabalhadores (CTs) estão mais habituadas é a discutir com a direção de pessoal mas num quadro de relações mais local, enquanto que os elementos dos sindicatos têm outro âmbito, têm outra abertura e têm maior 
conbecimento dos problemas que vão surgindo no seu dia-a-dia. As CTs, não é uma crítica, mas os elementos da CT penso que não têm grande conbecimento dos acordos coletivos de trabalho, enquanto que os elementos do sindicato, por funções que têm que exercer, têm que ter um conbecimento profundo, não só das leis do trabalho mas da negociação dos acordos que fazem com a entidade patronal. (...)

Enquanto que as CTs não passam do espaço português, os sindicatos têm uma relação privilegiada com as outras centrais sindicais. Estou a falar na questão de Espanha, onde temos a UGT espanhola e as Comissiones Obreras, com as quais nós temos boas relações, e com quem temos reuniões quase que permanentes, chamando-as assim aos encontros mundiais ou na Europa que nós temos. E temos boas relações com a UNI, que tem uma task force que está permanentemente em Bruxelas a negociar estes problemas. Eu acho que efetivamente as CTs têm um melhor conhecimento da empresa, porque estão lá dentro, porque têm contacto, enquanto que os sindicatos estão fora. Mas no âmbito dos CEEs têm mais conhecimento, melhores contactos... (Coordenador do CEE do Grupo BES, 12.10.2010)

\subsection{Um "modus operandi" assente na busca de respostas}

Os problemas em qualquer setor são a melhor forma de "pôr à prova" a capacidade de resposta do CEE e, como tal, para ver o espaço para a implementação de boas práticas. Os processos de aquisição ou de fusão suscitaram diretamente a intervenção do CEE, como foi referido anteriormente e como foi corroborado pelo coordenador português do CEE do grupo BES: "quando há aquisições ou quando há fusões é que nós intervimos diretamente aqui" (entrevista, 12.01.2010). Mas nos últimos anos, o contexto de crise financeira que perpassou o sistema bancário foi o fator mais desafiante à atuação do CEE do grupo BES. Este, ao mesmo tempo que procurou tranquilizar trabalhadores na sequência da falência do Lehman Brothers, pressionou a administração a informar devidamente os trabalhadores diretamente afetados nas sucursais espanholas e a resolver a sua situação: 
Por dentro do azar que houve com a crise financeira que se verificou, nós fomos apanhados quando estávamos em Espanha, quando bouve a falência do Lehman Brothers. E nós aí tivemos um papel muito importante, ao ponto de a administração claramente nos ter dito que fizemos um ótimo trabalbo. Ou seja, quando os bancos estavam a fechar e quando havia clientes que iam ao Banco Espírito Santo (estamos a falar do Banco Espírito Santo em Espanha) saber como é que estavam os seus depósitos no Lebman Brothers, aí o CEE teve um papel fundamental. Não só tranquilizando os trabalhadores, dizendo que o Banco Espírito Santo, embora sendo pequeno em Espanha mas era um grande Grupo em Portugal, dos maiores Grupos financeiros de Portugal. Portanto, as informações que a administração nos transmitia era que em Espanha não haveria despedimentos, não haveria encerramentos de balcões. E aos clientes o Banco queria, enfim, fazer um ofício a dizer que o problema era do Lebman Brothers e não do Banco. Nós conseguimos travar essa situação através do diálogo. Conseguimos que o Banco mandasse uma carta, resolvesse os problemas caso a caso e não houve problemas absolutamente nenhuns. Mais, os trabalbadores acreditaram em nós, nós trouxemos algumas informações importantíssimas. Tive o cuidado de dizer ao Dr. Ricardo Salgado qual era a nossa opinião, mas achávamos que a informação aos trabalhadores bancários espanhóis, do Banco, estava a ser muito mal transmitida, não havia praticamente informação (...).

Aquilo foi a uma sexta-feira e havia colegas que estavam a pensar não ir trabalhar na segunda-feira, com receio de represálias dos clientes, porque houve três balcões que tinham problemas, em que havia muitos investimentos do Lehman Brothers: foi Vigo, Santander e aqui um perto do Centro, Salamanca (...).

Numa situação de crise o CEE faz aquilo que deve fazer ou não faz. Se não faz é porque as pessoas que estão lá não estão interessadas. Porque as pessoas, em princípio, são todas competentes, não é! Ou não fazem aquilo que devem fazer ou não estão interessadas. Nesse aspeto, como lhe digo, em Espanha foi uma luta terrível, foi uma semana diabólica, diabólica, mas conseguimos transmitir coragem, esperança e deixar os trabalhadores, os nossos colegas espanhóis descansados. Dissemos o que o Banco nos disse, que o seu alvo principal do crescimento era Angola e Espanha. Eu perguntei ao Dr. Ricardo se era para crescer organicamente ou se era para crescer por aquisição e ele 
disse: "as duas questões estão em cima da mesa, se houver alguma empresa em saldo nós vamos lá". E tanto é assim que eles compraram o fundo de pensões do Banco Pastor... (Coordenador do CEE do Grupo BES, 12.10.2010).

Outro domínio que revelou intervenção do CEE prendeu-se com o Banco BES nos Açores:

Nós tivemos uma visita aos Açores. Embora seja Espírito Santo é outro Banco, porque o Banco BES Açores só tem 57\%, sendo que 33\% penso que é das Misericórdias e 10\% é de um grupo de hotéis dos Açores. Portanto, a Comissão de Trabalhadores aí já não pode intervir. E enquanto CEE conseguimos intervir. Também há questões muito pequenas... só para lhe dar um exemplo, o crédito à habitação, os colegas tinham alguma dificuldade em aceder ao crédito à habitação. Nós falámos com a administração açoriana e depois com a administração central e aquilo foi imediatamente resolvido. Mais um assunto que foi resolvido (Coordenador do CEE do Grupo BES, 12.10.2010).

Outro desafio que os CEEs têm igualmente pela frente, nomeadamente os trabalhadores do Grupo em Espanha, prende-se com questões de acesso a programas informáticos e com o excesso de entraves burocráticos:

Considerando a grande burocracia existente, inclusive nas aplicações informáticas, com a necessidade de códigos diferentes para se consultar um só processo, e a morosidade verificada, por exemplo na abertura de um depósito a prazo, com uma grande complexidade de tarefas, seria importante que se conseguisse uma melhor racionalização de procedimentos (CEE do Grupo BES, 2010b: 8).

$O$ facto de o CEE do BES ir dando conta destes problemas junto da "casa-mãe" em Portugal e de os fundamentar devidamente junto da sede tem recebido, segundo nos foi transmitido, um bom acolhimento por parte da administração.

Na verdade, o contexto de atuação do CEE do BES parece estar "imune" às adversidades económicas, ou decorre num quadro em que, apesar das 
perdas mais recentes do Grupo, tem ficado fora delas ${ }^{84}$. Pelo menos no momento em que o nosso interlocutor foi contactado, o funcionamento do CEE do BES não era perturbado pelo contexto económico adverso (embora atuasse no sentido de rebater tal contexto), facto que também explica a relativa tranquilidade patenteada pelo seu representante. Assim, quando questionado sobre o que significaria um agravamento da crise financeira (traduzida na perda de postos de trabalho, por exemplo), o coordenador do CEE do Grupo BES afastou do dia-a-dia dos problemas do CEE esse cenário:

Nós ainda não tivemos essa experiência. Aliás, o que o Banco nos tem informado é que está a crescer. Moçambique, a questão da aquisição do banco líbio, a questão da abertura na Argélia, a questão do México, Barhain. Eles informam de todas essas aquisições. Agora, o que sabemos é que, palavras do presidente da Comissão Executiva, o Banco quer crescer em Espanha, organicamente e através de aquisição. (Coordenador do CEE do Grupo BES, 12.10.2010).

Mas a situação não é de euforias e talvez por isso, quando confrontado com as tipologias relativas ao funcionamento dos CEEs baseadas em Lecher et al. (1999; 2001; 2002), a opção do representante do CEE recaiu sobre o CEE orientado para projetos, não obstante o CEE poder permitir-se discutir matérias que vão além do que o texto da Diretiva estipula e não obstante o próprio acordo do CEE do Grupo BES ser mais ambicioso do que a Diretiva estipula (como se referiu a propósito das questões salariais). Recorde-se uma vez mais que o CEE orientado para projetos define e executa projetos baseados no desenvolvimento

84 Mesmo em contexto de agudizada crise económica, e mesmo atendendo ao facto o BES ter visto os seus lucros diminuídos para 60,9 milhões de euros - ou seja, menos 48,9\% face ao período homólogo de 2010 (Público, 3.05.2011) -, o que é facto é que o Grupo registou um aumento do volume de depósitos na ordem dos 15,2\% em termos homólogos, no final do primeiro trimestre de 2011, traduzindo-se numa captação suplementar de 4 mil milhões de euros. (http://www.oje.pt//noticias/negocios/depositos-no-bes-crescem-152). Por sua vez, no primeiro semestre de 2011 o BES registou "apenas" 156 milhões de euros em lucros líquidos (no $1 .^{\circ}$ semestre de 2010 havia registado 282 milhões de lucros líquidos), o que significa uma queda de 44,7\% (Público, 2.08.2011). Apenas no primeiro trimestre de 2013, o BES apresentou prejuízos de 62 milhões de euros, valor que em 2012 (no período homólogo) se traduzira num saldo positivo de 11,6 milhões. Daí estar no horizonte (até 2016) um plano de redução de custos até cem milhões de euros (Público, 8.05.2013). 
sistemático das suas estruturas internas operacionais e de comunicação. Define as suas próprias tarefas (projetos), as quais, se necessário, tem capacidade para implementar independentemente da administração. Esta abordagem sistémica e estratégica serve para consolidar e construir o CEE, cimentar a confiança mútua e as experiências de cooperação entre os seus membros, assim como criar estruturas sustentáveis para o seu funcionamento - desenvolvendo uma "mais-valia institucional". Os projetos - por exemplo, a recolha sistemática e a troca de informação relacionada com as condições (nacionais) de trabalho, padrões sociais, etc. -, dão origem a recursos informativos transnacionais que poderão ser usados nas interações com a administração central ou local da empresa, e que demarcam e estruturam novos tópicos para negociação.

O envolvimento, em 2009, do CEE do BES na proposta do "prémio Dr. Manuel Ricardo Espírito Santo Silva" - que visa incentivar e premiar o empenho de trabalhadores que se destaquem de modo eminente na área bancária, designadamente nos domínios técnico, da gestão de recursos de pessoal, na performance comercial, na área social e na inovação, entre outras (CEE do Grupo BES, 2009: 1) - é um exemplo que parece ir ao encontro desta interpretação do coordenador do CEE do BES:

Eu classificaria o CEE como orientado para projetos. No último, no supra-sumo, não... Agora na questão de recolha de informações, discutir com a administração, apresentando sugestões sempre no âmbito de dizer que é a nossa opinião, que é para ficar bem claro. E posso reportar-lhe a questão da informação, da maior informação do Grupo em Espanha (...). A criação do Prémio Manuel Ricardo Espírito Santo foi obra do CEE. Nós é que apresentámos à administração e a administração aprovou. Nós fizemos um regulamento, a administração não seguiu o nosso regulamento mas tínhamos razão uma vez que hoje está a aproximar-se do nosso regulamento, que era um prémio carreira e não para pessoas novas. Ainda no outro dia estive numa reunião... e participamos na reunião de escolba dos trabalbadores que vão ser premiados com esse prémio. Eu estive presente nessa reunião em que escolhemos os elementos que no Congresso do Banco vão ser distinguidos (Coordenador do CEE do Grupo BES, 12.10.2010). 


\section{A visão das entidades patronais}

Como foi dito no capítulo 1, a posição das associações patronais europeias sempre se revelou muito defensiva face ao papel e relevância dos CEEs. O processo de revisão da Diretiva 94/45/CE conheceu, na verdade, resistências do patronato europeu e não foi sem dificuldades que o processo de revisão se concretizou e a nova Diretiva entrou em vigor em junho de 2011. Mesmo não sendo essa a nossa preocupação central, vale a pena olhar para alguns (dos poucos) estudos que tentaram sistematizar contributos da visão do "capital" sobre os CEEs, mesmo sabendo que tais estudos - sobre as práticas das administrações em relação aos CEE - são também (tal como os estudos sobre o "trabalho") muito variáveis (Marginson et al., 2009). Começaremos por uma breve análise das pesquisas realizadas no contexto europeu, para depois recuperarmos alguns dos aspetos mais relevantes da visão do patronato português (i.e., direções de empresas portuguesas, ainda que de filiais de multinacionais sedeadas noutros países), com base na investigação de Costa e Araújo (2007b; 2009).

\subsection{Os CEEs entre um criticismo convicto e um otimismo defensivo?}

Num estudo centrado no setor químico e realizado em 2005, Jeremy Waddington (2006b) considerou não existir uma evidência clara de que os representantes de trabalhadores em CEEs tenham conseguido impor uma agenda sindical aos CEEs. Pelo contrário, o que se verifica é que eles têm tido que lutar para que a agenda "regular" seja mantida. Ora, esta constatação parece ser influenciada pelo papel das administrações das empresas face aos CEEs. Em seu entender, três aspetos importantes sobressaem dos resultados sobre as atitudes das administrações. Primeiro: a ausência de qualquer uniformidade na agenda dos CEEs indica que as administrações de muitas empresas estão a atuar no sentido de restringir o conteúdo e a qualidade da informação e da consulta. Segundo: apesar da opinião expressa pela UNICE (atual Business Europe), não existe qualquer evidência de que se esteja a caminhar na Europa para um modelo 
único de representação. Pelo contrário, o efeito conjunto dos termos da Diretiva e a resistência dos empregadores em cumprirem até os requisitos mínimos da agenda, levaram a uma grande variação na natureza e na forma da representação laboral transnacional na Europa. Terceiro: as administrações conseguiram impedir os CEEs de se sobreporem ao processo de tomada de decisões.

O realçar de uma perspetiva crítica sobre os CEEs parece igualmente patente na investigação de Volker Telljohann (2007: 151-152). Para o autor, são identificáveis aspetos críticos no que diz respeito à relação entre os CEE e as administrações das empresas. Esta relação é determinada, por um lado, pela quantidade, qualidade e oportunidade do processo de informação e, por outro lado, pela presença ou ausência de procedimentos de consulta. Na grande maioria dos casos poder-se-á dizer que a estratégia das administrações é minimalista. Isto é, a administração tenta cumprir as suas obrigações sem espaço para mais nada do que o necessário. Em especial quando o que está em causa são processos de reestruturação, a investigação de Telljohann mostra que, no que respeita aos processos de informação, tanto a qualidade como a oportunidade são consideradas inadequadas. Nestes casos, as administrações tentam fazer valer as suas prerrogativas e, consequentemente, limitar a capacidade de ação dos CEEs. Noutros casos as administrações tentam manipular e controlar os CEEs de modo a atingir os seus objetivos estratégicos.

Para o autor, apenas numa minoria de casos há uma estratégia construtiva da administração. Nestes casos a administração mostra disponibilidade para conceder ao CEE direitos que vão para além dos parâmetros que a Diretiva estipula. Esta atitude da administração pode ser o resultado de interesses comuns, por exemplo no campo das políticas laborais ou da responsabilidade social das empresas. Nestes casos, a administração aceita voluntariamente o CEE como um parceiro. Noutros casos, em especial nas reestruturações, é o CEE em conjunto com os sindicatos que, pela ação coletiva, "forçam" a administração a aceitar o CEE como um parceiro.

Nos estudos de Waddington e Telljohann está, pois, bem patente a ideia de que as administrações das empresas veiculam uma perspetiva vincadamente crítica sobre os CEEs. Há, no entanto, outras perspetivas 
mais otimistas (ou pelo menos não tão críticas). O papel de dinamização da comunicação nas multinacionais propiciado pelos CEEs, por exemplo, é um dos aspetos que, nos escassos estudos que consideram a posição das administrações relativamente aos CEEs (Wills, 1998; Nakano, 1999; Weber et al., 2000; Müller e Hoffmann, 2001; Vitols, 2003; 2009), pode ser visto como um contributo positivo. Embora as administrações das multinacionais reconheçam e critiquem os custos associados aos CEEs, tendem a reconhecer-lhes vantagens no plano da comunicação interna e do envolvimento dos trabalhadores na vida da empresa, vantagens que representam requisitos fundamentais para o desenvolvimento de uma identidade corporativa à escala das multinacionais. A partir de um inquérito destinado a avaliar as atitudes dos gestores de recursos humanos que participam em CEEs (163 empresas inquiridas com uma taxa de resposta de 38\%), S. Vitols (2003) destaca duas atitudes principais: uma menos expressiva, que considera os CEEs como eventos turísticos; e outra mais generalizada, que considera que os CEEs desempenham um importante papel enquanto plataforma de comunicação pan-Europeia com efeitos positivos na informação dos trabalhadores, numa maior aceitação das decisões das administrações por parte dos trabalhadores, e na qualidade das decisões. Segundo o autor, é este o grupo que tem maior probabilidade de criar condições para melhorar o desempenho dos CEEs, acompanhando desta forma a sua maturação.

Sigurt Vitols (2009) destaca igualmente o impacto que os CEEs têm no bem-estar social de gestores/diretores das empresas, embora constate que se trata de uma área de estudo ainda pouco desenvolvida e algo negligenciada. Em estudos realizados em 2001 e 2006 sobre o tema, e tendo por base um inquérito postal dirigido a gestores de topo de empresas com CEEs (complementado com entrevistas aprofundadas a uma amostra mais reduzida), Sigurt Vitols analisou os desafios que os diretores enfrentam na gestão quotidiana de empresas multinacionais e a experiência dos CEEs enquadrada no âmbito desses desafios. Em geral, conclui-se que os gestores têm uma visão favorável dos CEEs, e muitos desejam que os CEEs possam desempenhar um papel mais forte e decisivo na gestão dos desafios que se colocam às empresas multinacionais. Além disso, os CEEs 
são vistos como entidades que desempenham funções que são difíceis de preencher ao nível nacional nas empresas multinacionais: configuram-se como plataformas de discussão entre trabalhadores e diretores que podem ser difíceis de existir ao nível nacional, quer em resultado dos processos de fragmentação laboral, quer em resultado da existência de relações laborais adversas.

Os assuntos que mais frequentemente são discutidos pelos CEEs são os que dizem respeito à situação financeira da empresa, mas também à sua cultura empresarial. Outros, como as deslocalizações ou as fusões, têm vindo a ganhar terreno nas agendas dos CEEs. Apesar de haver uma grande diversidade de opiniões dos diretores/gestores sobre o efeito que os CEEs têm nas suas empresas, Vitols (2009: 17) realça uma visão positiva sobre os CEEs: $67 \%$ dos gestores concordam que os CEEs vieram melhorar a comunicação com os trabalhadores ("alguma coisa" ou "significativamente"), contra apenas $2 \%$ que afirmaram que a comunicação piorou. Quase 2/3 acham que o empenhamento dos trabalhadores melhorou, e nenhum acha que neste capítulo o impacto tenha sido negativo. Por outro lado, 37\% acreditam que a forma de implementação de decisões da gestão se tornou mais ágil e célere com os CEEs, contra apenas 3\% que acham o contrário. Somente no que respeita à "velocidade do processo de decisão" houve um equilíbrio entre respostas positivas e negativas.

Concluindo, a maioria dos gestores é da opinião de que os CEEs se afiguram como uma plataforma válida para a discussão de importantes matérias relacionadas com a cultura corporativa e com os desenvolvimentos/planos transfronteiriços das empresas. A grande maioria dos gestores também veem os CEE como órgãos que desempenham um importante papel no incremento da comunicação com os trabalhadores, potenciam o empenhamento destes no cumprimento dos objetivos da empresa e melhoram a capacidade de implementação das decisões empresariais. Em suma, do ponto de vista dos gestores os CEEs resultam num aumento claro do seu bem-estar social.

Importa, por fim, olhar para a investigação sobre as administrações conduzida por Marginson e colaboradores. Baseando-se num trabalho 
empírico realizado em três países - Espanha, Irlanda e Reino Unido ${ }^{85}$ - Marginson et al. (2009) classificam as práticas das administrações em relação aos CEEs em duas categorias principais: minimalista e pró-ativa. Segundo uma abordagem minimalista, o objetivo da administração é conter ou restringir o papel do CEE a um simples lugar simbólico, no qual a administração exerce um controlo da agenda e a informação prestada limita-se à apresentação geral da performance financeira da empresa ou das perspetivas de negócio futuras (muitas vezes escassas), não havendo consulta efetiva e quase nenhum contacto com representantes dos trabalhadores entre as reuniões anuais obrigatórias. Na abordagem pró-ativa, a administração vê no CEE uma estrutura com potencial para desempenhar um papel ao nível da compreensão, de legitimação das decisões empresariais e das suas consequências para os representantes dos trabalhadores e a força de trabalho em geral. Nestes CEEs "ativos”, a representação dos trabalhadores desempenha um papel importante na definição da agenda, as informações são mais abrangentes, completas e dadas em tempo útil, há consulta por parte da administração em relação a (alguns) assuntos e formas de contacto regulares entre a administração e os representantes dos trabalhadores. Como recordam Marginson et al. (2009), estudos anteriores de Lecher et al. (2001) e Marginson et al. (2004) conseguiram identificar vários níveis de pro-atividade por parte das administrações com uma prática mais extensiva, envolvendo o alerta sistemático dos representantes dos trabalhadores sobre decisões relevantes, e consulta mais extensiva - e até negociação - sobre as consequências de processos de reestruturação. Para aqueles autores, os inquéritos realizados centraram-se principalmente sobre as atitudes das administrações em relação aos CEEs (Nakano, 1999; Vitols, 2003; Wills, 1999) e não tanto sobre as práticas

85 O estudo utiliza uma análise multivariada regressiva no esclarecimento dos fatores que moldam a incidência de CEEs nas empresas multinacionais e os fatores que contribuem para a variação das práticas de informação e consulta levadas a cabo pelas administrações dessas empresas. Na explicação para a variação da incidência de CEEs nas multinacionais, os autores consideram a influência de quatro grupos de fatores: propriedade; demográficos (setor, volume de emprego, etc.); estratégia empresarial e estrutura administrativa (incluindo o nível de internacionalização); e organização da força de trabalho. O inquérito foi aplicado com base numa entrevista estruturada ao diretor de recursos humanos de 260, 330 e 320 multinacionais de cada um dos três países, respetivamente. 
das administrações. No entanto, as conclusões são convergentes com a distinção entre abordagens minimalistas e pró-ativas.

As multinacionais sedeadas em países anglófonos, sobretudo fora da Europa, têm pouca experiência interna de informação e consulta dos representantes dos trabalhadores. As administrações, se bem que procurem estar de acordo com as regulamentações existentes, poderão inclinar-se para restringir o papel dos CEEs e prosseguir uma abordagem minimalista. Pelo contrário, as multinacionais de países situados na plataforma ocidental continental europeia e os países nórdicos desde há muito estão familiarizados com as práticas de informação e consulta dos representantes dos trabalhadores (e dos benefícios que daí poderão decorrer), estando por isso mais inclinados para adotarem uma abordagem pró-ativa. Para Marginson et al (2009: 5), os representantes dos trabalhadores nos CEEs referem práticas de informação e consulta mais extensivas nas multinacionais cujas sedes se situam na Europa continental e nos países anglófonos, desde logo porque estes países tiveram que adaptar-se ao princípio da representação laboral universal em matéria de informação e consulta por forma a corresponderem a uma série de Diretivas europeias.

Por outro lado ainda, se a multinacional é propriedade privada, as obrigações gerais para fornecer informações sobre a sua situação e sobre as perspetivas futuras de negócio são, em geral, menores do que quando as empresas são publicly-trade companies. O que significa que nas empresas privadas é previsível a adoção de uma abordagem minimalista da direção em relação aos CEEs.

Em relação às respostas obtidas sobre os procedimentos de informação e consulta da administração a propósito dos CEEs, a percentagem que se aproxima de uma abordagem minimalista da administração varia entre os três países: 19\% nas multinacionais com operações em Espanha; 31\% nas multinacionais com operações na Irlanda; e 30\% nas multinacionais com operações no Reino Unido. A proporção dos que descrevem a abordagem da administração como pró-ativa totaliza 34\% e 33\% entre as multinacionais com operações em Espanha e Irlanda, respetivamente, mas apenas $15 \%$ entre as multinacionais com operações no Reino Unido. 
O inquérito aplicado em Espanha e no Reino Unido também questionava os administradores da empresa a nível nacional sobre se assistiam à reunião do CEE e, caso não assistissem, se eram sistematicamente informados sobre as reuniões do CEE e/ou sobre a sua atividade. Entre as empresas com operações em Espanha e com CEEs, quase metade (48\%) disseram que um administrador assistia regularmente às reuniões do CEE, ao passo que $4 \%$ afirmaram que isso sucedia ocasionalmente. Por sua vez, $35 \%$ dos inquiridos em multinacionais com operações no Reino Unido e com CEEs garantiram assistir regularmente às reuniões e cerca de $11 \%$ iam ocasionalmente. Se os administradores não assistiam regularmente às reuniões do $\mathrm{CEE}$, os administradores nacionais eram sistematicamente informados sobre a atividade do CEE durante as reuniões em 2/3 dos casos em Espanha e no Reino Unido. Em relação ao outro terço restante, a maioria reconhece que é informada "em termos gerais", apesar de haver 10\% nos dois inquéritos que garantem não ter recebido qualquer informação.

Em relação ao possível efeito que o setor de atividade tem sobre a prática das administrações em relação aos CEEs, os dados apurados não mostram uma variabilidade significativa entre o setor secundário e o dos serviços. Também contra as expectativas, o grau de integração internacional não interfere significativamente na prática da administração em relação ao CEE. Já a presença de uma estrutura europeia de administração como interlocutora do CEE tem alguma influência. Quando a multinacional possui um comité internacional de recursos humanos, as práticas de informação e consulta da administração tendem a ser mais extensivas. A presença sindical no país de acolhimento não tem efeito aparente na prática da administração. Enquanto que a taxa de sindicalização nas operações das multinacionais tem um importante impacto no estabelecimento de CEEs, é provavelmente a presença de efetivas organizações sindicais transfronteiriças que mais influencia e molda a prática das administrações. Em relação à propriedade (ownership), as multinacionais com sede no norte da Europa têm maior probabilidade de terem práticas de informação e consulta mais extensivas do que as multinacionais com sede na América do Norte, o que já não é verdade para as multinacionais com sede na plataforma continental ocidental europeia. 


\subsection{Ilações do caso português: permissividade, mas com indiferença}

Baseando-se num inquérito aplicado às administrações portuguesas de multinacionais com representantes de trabalhadores em CEEs, Costa e Araújo (2007b: 234-244; 2009: 173-184) confrontaram-nas com os seguintes temas: (i) o processo de constituição do CEE; (ii) a participação da administração nas atividades do CEE e a avaliação do papel do CEE; (iii) as competências e impactos dos CEEs; (iv) e as principais vantagens e limitações associadas aos CEEs. Apesar da modesta percentagem de respostas $^{86}$ recomendar prudência analítica, alguns importantes resultados do inquérito em cada um daqueles pontos merecem ser mencionados:

(i) Relativamente ao processo de constituição dos CEEs, e contrariamente ao entendimento dos representantes de trabalhadores ${ }^{87}$, constata-se que os representantes das administrações locais atribuem a iniciativa para a constituição dos CEEs às administrações centrais e tendem a negligenciar a intervenção das organizações de representação dos trabalhadores. De resto, igualmente ao contrário do que acontece com os representantes dos trabalhadores - que avaliam as negociações para a instituição dos CEEs como morosas e difíceis -, os representantes das administrações enfatizam a rapidez dos processos e o seu carácter consensual.

(ii) Quanto à participação das administrações locais nas atividades dos CEEs, Costa e Araújo constataram que a grande maioria dos representantes das administrações locais declararam ter acesso a informações sobre as atividades dos CEEs pelo facto de a difusão da informação, tanto aos trabalhadores como às administrações, constituir uma prática de funcionamento dos CEEs. E isso é assim considerado independentemente de os

${ }^{86} \mathrm{O}$ inquérito foi aplicado em 139 multinacionais, tendo apenas 30 destas respondido, o que corresponde a uma taxa de resposta de $21,6 \%$. No entanto, atendendo a que se trata de contactar o "capital", estamos em crer que a taxa de respostas não deve ser desconsiderada. Além disso, como foi mencionado no capítulo 1, um inquérito aplicado em 2005 por Jeremy Waddington a 2.392 representantes de CEEs de 196 empresas obteve um índice de respostas de 19,8\%, valor (este sim) considerado baixo se atentarmos que, neste caso, se tratou de um inquérito dirigido a representantes de trabalhadores.

87 Os representantes portugueses dos trabalhadores atribuem maioritariamente a iniciativa para formar os CEEs aos trabalhadores organizados da sede das multinacionais (sindicatos, federações de sindicatos, etc.) ou à própria administração central das multinacionais. 
CEEs serem mistos (compostos por representantes dos trabalhadores e das administrações) ou unilaterais (compostos unicamente por representantes dos trabalhadores). Na prática, o acesso das administrações a informação sobre as atividades dos CEEs traduz-se numa avaliação positiva da sua participação nas atividades dos CEEs.

(iii) Quanto à avaliação das competências e impactos dos CEEs, um dado relevante do caso português diz respeito à defesa dos interesses locais. Para os representantes das administrações, a defesa dos interesses locais aparece como uma função que os CEEs deveriam assumir e desempenhar mais ativamente em sede dos CEEs, o que reflete uma visão paroquial dos CEEs algo semelhante à manisfestada pelos representantes dos trabalhadores. O papel dos CEEs relativo aos processos de comunicação interna (entre administração e trabalhadores) e externa (com as restantes sucursais) afigura-se como outra competência positiva dos CEEs e que estes deveriam desempenhar mais ativamente. Como ficou dito acima, vários estudos realçaram precisamente a maximização da comunicação enquanto contributo importante dos CEEs para a performance das multinacionais.

Os representantes das administrações tendem a classificar positivamente os CEEs. No entanto, esse facto não encontra correspondência nem no número reduzido de respostas quando questionados relativamente aos seus planos para melhorar o funcionamento dos respetivos CEEs, nem na avaliação dos impactos dos CEEs. Este ponto - relativo aos efeitos atribuídos aos CEEs pelas administrações locais - suscitou quatro considerações sobre os seguintes aspetos: impactos dos CEEs ao nível da participação dos trabalhadores na vida da empresa; nível dos processos de decisão (consulta); tipo de relações entre administração e trabalhadores; e efeitos práticos dos CEEs ao nível da visibilidade dos problemas locais, na resolução de problemas e na aquisição de benefícios via CEEs.

Relativamente à participação dos trabalhadores na vida da empresa, os representantes das administrações inquiridos apenas apontam melhorias no tocante ao envolvimento dos trabalhadores nos assuntos da empresa, o que não significa, porém, uma maior participação dos trabalhadores ao nível da implementação de novas estratégias ou da aceitação, por parte dos trabalhadores, de novas estratégias. Em segundo lugar, no que 
diz respeito à participação dos trabalhadores nos processos de decisão, embora os inquiridos reconheçam efeitos positivos ao nível da aceitação das decisões e da qualidade das decisões, eles acabam por concentrar as suas respostas na ausência de impactos significativos por parte dos CEEs. ${ }^{88}$ Em terceiro lugar, no que concerne às relações entre administração e trabalhadores, os CEEs parecem ter trazido algumas melhorias apenas ao nível da comunicação, mantendo-se a ausência de impactos na mediação de conflitos entre administração e trabalhadores e nos níveis de conflitualidade no seio das empresas. Finalmente, os CEEs parecem exercer uma influência positiva na visibilidade dos problemas locais ${ }^{89}$ que, apesar disso, não se traduz necessariamente nem na sua resolução, nem na aquisição de benefícios pelas empresas locais (Costa e Araújo, 2009: 181).

(iv) Por fim, e ante um défice generalizado de impactos práticos dos CEEs, importa considerar o modo como as administrações avaliam as principais vantagens e limitações dos CEEs. Ora, os representantes das administrações inquiridos reconhecem os CEEs como importantes parceiros na gestão da empresa; na articulação entre administração local e sede da multinacional; na comunicação entre administração local e trabalhadores; e enquanto instrumentos de Responsabilidade Social das Empresas. Os CEEs perdem, porém, importância enquanto mecanismos de redução dos conflitos.

Globalmente, não são significativas as limitações aos CEEs apontadas pelas administrações, mesmo quando lhe estão associados custos. O que se explica sobretudo porque uma parte substancial dos custos dos CEEs (traduções, interpretações, alimentação e estadias) é geralmente assegurada pelas administrações centrais. Por outro lado, os representantes das administrações locais são unânimes na consideração de que não existe

${ }^{88}$ A ausência de impactos significativos no tópico "tempo das decisões" revela sobretudo a inexistência de entraves colocados pelos CEEs aos processos de gestão das empresas (Nakano, 1999).

89 Ainda assim, enquanto as administrações tendem a ver os CEEs como uma fonte de informação adicional sobre o que "corre mal", os trabalhadores utilizariam os CEEs como um mecanismo de pressão adicional para resolver o que "está mal". 
uma duplicação de funções entre CEEs e ORTs (sindicatos, comissões de trabalhadores e comissões de higiene, saúde e segurança no trabalho) e que é positiva a relação entre CEEs e ORTs existentes. As administrações locais consideram, aliás, as ORTs como importantes parceiros dos CEEs, desempenhando estes funções que não competem/colidem com as das ORTs. Igualmente escassa é a interferência dos CEEs nos processos de decisão ${ }^{90}$. Finalmente, os CEEs parecem não contribuir significativamente para alterar os níveis de conflitualidade no seio das empresas.

Em resumo, como sustentam acertadamente Costa e Araújo (2009: 184), grosso modo a avaliação dos representantes das administrações locais portuguesas é favorável aos CEEs. No entanto, a participação das administrações nas atividades dos CEEs é diminuta e a sua atitude face aos CEEs é relativamente neutra ou mesmo indiferente, designadamente na avaliação que é feita do papel desempenhado pelos CEEs na vida das empresas, i.e., das suas vantagens e limitações e dos seus impactos efetivos. Esta atitude, quando confrontada com os relatos visivelmente mais positivos dos representantes dos trabalhadores, leva os autores a sustentar que o não reconhecimento dos impactos dos CEEs pelas administrações locais se deve quer a uma estratégia de desvalorização dessas instituições, quer ao próprio défice de poder dos CEEs.

90 Segundo S. Nakano (1999), a par do aumento das expectativas dos trabalhadores quanto ao poder efetivo dos CEEs para alterar decisões, a interferência nos processos de decisão constituiria um efeito secundário negativo associado aos CEEs pelas administrações centrais. Tal não encontra, porém, expressão nos representantes das administrações locais inquiridos. 
(Página deixada propositadamente em branco) 


\section{CON CLUS Ã O}

Em tempos de austeridade económica e de crise social, também os CEEs são instituições postas à prova, designadamente ante processos de deslocalização, encerramentos, fusões de empresas, entre outros. Não se esqueça, aliás, que é a própria ideia de "Modelo Social Europeu" que se encontra hoje ameaçada por uma série de tendências de sentido negativo: aumento dos impostos; incentivo ao aumento dos horários de trabalho; elevação da idade da reforma; pressão para a privatização dos sistemas de pensões; enfraquecimento da legislação que protege o emprego; redução dos apoios diretos ao desemprego; liberalização do setor público, etc. (Costa, 2012b).

Centrando-se nos CEEs enquanto objeto de estudo, este livro propôs-se analisar as possibilidades de participação dos trabalhadores na empresas multinacionais. Através de uma análise aprofundada dos CEEs - instituições resultantes da Diretiva Comunitária 94/45/CE, de 22.09.1994, entretanto substituída pela Diretiva 2009/38/CE (de 9.05.2009), em vigor desde 6.06.2011 -, foram avaliados os mecanismos de informação e consulta dos trabalhadores nas empresas ou grupos de empresa de dimensão comunitária, ou seja, empresas com 1.000 ou mais trabalhadores dentro do Espaço Económico Europeu (EEE, isto é, os Estados-membros da União Europeia, bem, como a Islândia, Noruega e o Liechtenstein) e em que pelo menos dois Estados-membros diferentes do EEE empreguem um mínimo de 150 trabalhadores em cada um deles.

Foi conferido um destaque especial a três setores - metalúrgico, químico e financeiro -, por sinal setores onde é mais significativo o número de multinacionais com CEEs constituídos e maior a presença de represen- 
tantes portugueses eleitos/nomeados para CEEs. Além disso, trata-se de setores particularmente vulneráveis a tais processos de reestruturação, deslocalização e fusão, pondo, assim, à prova a função dos CEEs e a sua capacidade de resposta.

Tratou-se, pois, de analisar os impactos da Diretiva 94/45/CE e, desde 2009, da Diretiva 2009/38/CE. E esse desafio foi perseguido de molde a conjugar objetivos de recorte multidisciplinar (ainda que tendo a sociologia como ponto de partida) em três principais planos de análise: por um lado, no plano teórico, dando conta da componente analítica do tema; por outro lado, no plano do tratamento quantitativo e normativo, por meio da análise dos acordos de CEEs nos 3 setores em estudo; e ainda no plano de análise qualitativa, caracterizando estudos de caso naqueles setores.

No plano teórico foi possível: situar o contexto necessário a uma regulação social das multinacionais; compreender os antecedentes da Diretiva 94/45/CE; esclarecer os objetivos e funções dos CEEs, bem como as principais transformações associadas ao processo de revisão da Diretiva, com a entrada em vigor da Diretiva 2009/38/CE; identificar tipologias de CEEs; bem como testemunhar "boas práticas" no funcionamento dos CEEs.

Por sua vez, no plano do tratamento quantitativo e normativo da "letra de lei" dos acordos de CEEs foi possível analisar: bases de dados; acordos em vigor por país de sede das multinacionais e por setor de atividade; e a natureza dos acordos (tipo de acordo, subscritores, legislação aplicável, duração do acordo, composição do CEE, carácter abrangente/restrito dos acordos, oportunidade da informação e da consulta, formas de eleição dos representantes, funcionamento das reuniões, etc.).

Em terceiro lugar, no plano da análise qualitativa, realçaram-se os estudos de caso que permitiram: captar a diversidade de questões/problemas em cada setor de atividade; conhecer as visões dos representantes de trabalhadores portugueses; identificar "boas práticas" de CEEs em empresas de referência (Costa, 2013); sistematizar a opinião das entidades patronais.

Nos três setores em análise (metalúrgico, químico e financeiro), foi possível constatar que os CEEs são ainda atravessados por dificuldades de afirmação, nomeadamente em torno da construção de uma identidade 
laboral transnacional. Na verdade, a informação e consulta de trabalhadores em empresas de dimensão comunitária é ainda condicionada quer por défices inerentes à construção de um "sistema europeu de relações laborais", quer pelos obstáculos a uma normatividade laboral transnacional favorável às preocupações do mundo laboral. Além disso, muitas vezes os próprios representantes de trabalhadores em CEEs sentem que o seu espaço de ação está aquém do que seria desejável e em vez da cooperação transnacional, as preocupações de âmbito nacional ou o efeito de home advantage parece ainda levar a melhor sobre as estratégias de informação e consulta de âmbito transnacional.

Em convergência com alguns estudos sobre CEEs, podem assinalar-se três tendências de fundo. Em primeiro lugar, ainda que sejam organismos orientados pela valorização e para o incremento da participação laboral, na ótica dos representantes portugueses os CEEs não detêm poder suficiente para equilibrar as relações de força no seio das multinacionais. Não surpreende, pois, que a aquisição de um maior poder de decisão e de intervenção por parte dos CEEs apareçam como uma das dimensões reivindicadas pelos representantes portugueses para melhorar o desempenho dos CEEs. E isto é verdade mesmo nos casos de multinacionais que normalmente "dão vida" aos CEEs, isto é, que permitem que, por meio deles, se dinamizem boas práticas de relacionamento entre administrações e trabalhadores.

Em segundo lugar, e em decorrência do ponto anterior, é atribuído um défice de resultados práticos aos CEEs. Por exemplo, sempre que uma multinacional enfrenta problemas graves (de reestruturação, deslocalização ou mesmo encerramento, parcial ou total) sem que os coletivos de trabalhadores consigam inverter o sentido das decisões tomadas pelas administrações reforça-se o sentimento de ineficácia dos CEEs. É verdade que os exemplos analisados neste livro (Grupo Volkswagen, Grupo Air Liquide e Grupo BES) apontam um caminho mais auspicioso, assente em boas práticas que importa reforçar e divulgar enquanto elementos de aprendizagem intra e inter setorial. Trata-se, porém, de multinacionais que têm estado mais "protegidas" face à crise e nas quais os receios de encerramentos ou de deslocalizações têm-se conseguido evitar. Na verdade, 
a "boa saúde" e o papel revelante desempenhado pelos CEEs dos Grupos VW, Air Liquide e BES explica-se não só pela prioridade concedida a uma cultura de diálogo entre capital e trabalho no seio das multinacionais, como porque, em qualquer uma daquelas multinacionais, os ventos fortes da austeridade não parecem ainda ter soprado com a máxima força.

Em terceiro lugar, e não obstante a tendência expressa nos dois pontos anteriores para uma relativa minimização dos efeitos práticos dos CEEs, o que é facto é que podem identificar-se vários aspetos positivos nos CEEs. Esta investigação permitiu também confirmar essa ideia, desde logo quando se tem em consideração que a questão da solidariedade transnacional constitui um bom pretexto para que se dinamizem os CEEs. Além disso, os representantes portugueses em CEEs nos setores em análise atribuem outras potencialidades aos CEEs: conferir aos representantes de trabalhadores maiores possibilidades de interlocução e afirmação perante as administrações locais; permitir às administrações centrais a aquisição de um maior conhecimento da amplitude dos problemas dos trabalhadores das diferentes filiais; propiciar uma melhor comparação entre filiais, de modo a percecionar melhor as distinções bem como as reivindicações; aceder a um patamar de decisão superior, exercendo formas de pressão secundárias, isto é, complementares aos mecanismos nacionais; reforçar uma cultura de diálogo social na empresa, etc. Assim sendo, é nestas dinâmicas produtivas que os trabalhadores devem apoiar-se no futuro tanto mais que é dessas possibilidades que dependerá a eficácia futura dos CEEs e a sua confirmação enquanto instâncias de regulação transnacional das relações laborais.

Devem, pois, parafraseando Jeremy Waddington (2011: 21-25), ser tidos em consideração três desafios amplos (Waddington designa-os de pontos de partida, mas na verdade podem configurar-se também como pontos de chegada) capazes de condicionar um bom desempenho presente e futuro dos CEEs, não só nos três setores aqui em análise, como nos CEEs em geral. Por um lado, o desafio da construção progressiva. Com efeito, os CEEs são ainda instituições em construção. Se é verdade que a maioria das instituições de relações laborais só se conseguem desenvolver de modo eficaz assim que alcançam um assinalável grau de coesão 
interna e confiança entre atores que as compõem - e isso normalmente leva tempo a conseguir à escala nacional -, no âmbito de instituições transnacionais como os CEEs o grau de exigência é ainda mais acrescido. Neste espaço, o desenvolvimento de competências transnacionais é elementar e ele implica, entre outros pontos: um conhecimento de distintas instituições, tradições e práticas de relações laborais; uma compreensão do tipo de estatuto, autoridade e direitos dos outros representantes (de outras nacionalidades); competências linguísticas e conhecimentos de diferentes tipos de culturas. Se é verdade que o apelo à criação de uma identidade laboral transnacional permanece na ordem do dia, não é menos verdade que o mesmo pode ser questionado, por exemplo, sempre que uma decisão de encerramento por parte de uma administração se torna irreversível. Nessas situações, os representantes dos trabalhadores dessa multinacional podem estar longe de atuar de uma forma transnacional conjunta, pois o discurso e as práticas paroquiais (associados à necessidade de proteger/garantir empregos nacionalmente) pode falar mais alto do que a solidariedade laboral transnacional. Não foi isso que sucedeu em Portugal no caso da Opel da Azambuja (encerrada em dezembro de 2006), multinacional onde se gerou uma onda de solidariedade entre os trabalhadores de várias filiais para com os mais de 1.000 representante portugueses que ficaram desempregados. Porém, é de admitir (e lamentar) que, num quadro de globalização e competitividade - apoiado numa perspetiva tecno-liberal dominante (Kovács e Lopes, 2012) -, a solidariedade seja relegada para segundo plano.

Por outro lado, está em aberto um desafio de articulação de atividades. Trata-se aqui de pensar a concretização das atividades de uns CEEs em sintonia com as atividades e funcionalidades de outros CEEs e dos seus membros (representantes). Mas trata-se ainda de procurar sinergias com outras instituições de representação de interesses laborais no seio da empresa (sindicatos, comissões de trabalhadores, comissões de higiene e segurança, etc.). Consequentemente, estamos perante um processo de aprendizagem intercultural, não apenas do seio do mesmo setor (o que pode ser um boa estratégia de começo), mas entre diferentes setores, tanto mais que seria importante transpor boas práticas de uns contextos para 
outros. Desde logo, divulgando-as onde elas possam ser menos conhecidas, usando por exemplo a Internet e as vantagens que esta oferece no sentido de acelerar e facilitar o acesso à informação.

Por fim, o desafio da contestação ou, se quisermos, da controvérsia em redor dos CEEs. Três áreas de potencial contestação/controvérsia podem ser assinaladas. Por um lado, a oposição patronal. Mesmo que esta possa ter sido porventura mais vincada no passado e mesmo que se possa sugerir que a Diretiva 2009/38/CE resulta da superação de conflitos entre patrões e sindicatos europeus, o que é facto é que lhe subjaz um histórico conflito entre capital e trabalho que, em contexto de crise económica, poderá estar mais próximo de ser retomado do que de ser esquecido. Por outro lado, porque o princípio da autonomia das partes confere quer aos representantes da administração quer dos trabalhadores a prerrogativa para definir a forma e o modo como se processam as práticas de informação e consulta em cada multinacional. Por outro lado ainda, uma terceira área de contestação no desenvolvimento dos CEEs refere-se a efeitos atribuídos à participação transnacional e à composição de cada CEE. Se é verdade que os CEEs se definem formalmente como instituições de participação laboral guiadas ou orientadas para a informação e consulta transnacional de trabalhadores, não é menos verdade que alguns representantes de trabalhadores em CEEs não deixam de olhar para estas instituições (e a nosso ver bem) enquanto fora a partir dos quais se podem gerar formas de solidariedade laboral internacional. Mesmo que não haja consenso dentro do "lado laboral" quanto à missão dos CEEs, não surpreende que essa questão geradora de tensão se verifique sobretudo na relação entre administrações e trabalhadores. Em todo o caso, estamos em crer que o que está em causa seja também a possibilidade (e necessidade) de dotar os CEEs de mais competências além da informação e da consulta de trabalhadores.

Em resumo, são de grande fôlego os desafios que se colocam às multinacionais e, consequentemente, aos CEEs enquanto "vozes do trabalho" (Costa e Araújo, 2009) que, no seu seio, clamam por ser ouvidas. Reforçar a sua visibilidade transnacional (e mesmo nacional) é, pois, crucial para o futuro destas instituições e para uma humanização das relações 
laborais. O que certamente anseiam os trabalhadores das multinacionais e as suas organizações é que a lei comunitária 2009/38/CE, que entrou formalmente em vigor em 6 de junho de 2011, se constitua como contributo afirmativo para um maior nivelamento das relações laborais no seio das multinacionais. 
(Página deixada propositadamente em branco) 


\section{S I G L A S}

AQ-G, Acordos-Quadro Globais

BES, Banco Espírito Santo

CEE(s), Conselho(s) de Empresa Europeu(s)

CEEP, Centro Europeu das Empresas de Participação Pública

CES, Confederação Europeia de Sindicatos

CES-UE, Comité Económico e Social da União Europeia

CGTP, Confederação Geral dos Trabalhadores Portugueses

CR(s), Conselho(s) Restrito(s)

CRP, Constituição da República Portuguesa

CT(s), Comissão(ões) de Trabalhadores

EEE, Espaço Económico Europeu

EMCEF, European Mine, Chemical and Energy Workers Federation/Federação

Europeia dos Trabalhadores das Minas, Química e Energia

EMF/FEM, European Metalworkers' Federation/Federação Europeia dos Metalúrgicos FSE(s), Federação(ões) Sindical(ais) Europeia(s)

GEN(s), Grupo(s) Especial(ais) de Negociação

GM, General Motors

OCDE, Organização para a Cooperação e Desenvolvimento Económico

OIT, Organização Internacional do Trabalho

OMC, Organização Mundial do Comércio

ORTs, Organizações Representativas de Trabalhadores

PIC(s), Procedimento(s) de Informação e Consulta

RSE, Responsabilidade Social das Empresas

SDA, Social Development Agency

TIC, Tecnologias de Informação e Comunicação

UE, União Europeia

UGT, União Geral de Trabalhadores

UNICE, União das Indústrias da Comunidade Europeia (atual BusinessEurope)

UNI-Europa, Union Network International-Europa/ Rede Sindical Internacional-Europa

VW, Volkswagen 
(Página deixada propositadamente em branco) 


\section{RE FER E N C I A S B I B L I O GRÁ F I CAS}

Air liquide (2011), Rapport annuel 2010 (http://rapportannuel.airliquide.com/ pdf/Air_Liquide_Rapport_Annuel_2010_FR.pdf). Paris. Groupo Air Liquide. BEIRNAERT, Jeroen (2006), Case study on best practices in EWC functioning. (http:// www.sda-asbl.org/testiPdf/Casestudy-UK.Pdf). Brussels: SDA/infopoint project.

Bercusson, Brian (2008), "Information and ConsultationRights in Jurisprudence", in M. Monaco e C. Weis (orgs.), Infopoint 2008 EWC Workshops: beyond the directive, towards effective rights for EWCs. Bruxelas: Social Development Agency/European Trade Union Confederation, 15-53.

BÉTHoux, Élodie (2004a), "Les Comités d'Entreprises Européens en quête de légitimité”, Travail et Emploi, 98, 21-35.

BÉTHOux, Élodie (2004b), "Comités d'entreprise européens et mobilisations du droit: l'information et la consultation des travailleurs au prisme des restructurations", 1er Congrès de l'Association Française de Sociologie (AFS), Villetaneuse, Février 2004.

BICKNELl, Helen (2007), "Ethno -, poly - and Eurocentric European Works Councils. How does German involvement influence their identity?", in Michael Whittall et al. (orgs.) (2007), Towards a European Labour Identity. The case of European Works Councils. Londres: Routledge, 111-131.

Blainpain, Roger (2009), European Works Councils. The European Directive 2009/38/EC of 6 May 2009. Alphen aan den Rijn: Kluwer Law International.

Blainpain, Roger (org.) (1998), International Encyclopedia of Laws. European Works Councils. Bedfordshire: Kluwer Law International.

Blanke, Thomas (1999a), "European Works Councils as an institution of European employee information and consultation: overview of typical features of national transposition provisions, outstanding legal questions and demands for amendments to EWC Directive 94/45/EC”, in European Trade Union Institute, A Legal Framework for European Industrial Relations (Report 60). Bruxelas: European Trade Union Institute, 39-56. 
Blanke, Thomas (1999b), "European Works Councils as an institution of European employee information and consultation: overview of typical features of national transposition provisions, outstanding legal questions and demands for amendments to EWC Directive 94/45/EC", Transfer - European Review of Labour and Research, 5 (3), 366-383.

Blanke, Thomas; Rose, Edgar (2010), "Who is fisrt? The correct timing of information and consultation of European Works Councils in relation to national rights of worker involvement", in Filip Dorssement and Thomas Blanke (orgs.), The Recast of the European Works Council Directive. Antuérpia: Intersentia, 327-356.

Blokland, Antoon (2002), Accounting for the 'missing' European Works Councils. University of Utrecht, $139 \mathrm{pp}$.

Bonneton, Pascale; CARley, Mark; Hall, Mark; Krieger, Hubert (1996), Review of current agreements on information and consultation in european multinationals. Report for the European Foundation for the Improvement of Living and Working Conditions and the European Commission. Luxemburgo: Office for Official Publications of the European Communities.

Burawoy, Michael (2000), "Grounding globalization”, in M. Burawoy et al. (orgs.), Global ethnography: forces, connections, and imaginations in a postmodern world. Berkeley: University of California Press, 337-350.

BuschaK, Willy (1995), "European works councils open new horizons", Transfer - European Review of Labour and Research, 1 (1), 133-135.

BuschaK, Willy (2004), "The practical and legal problems of European Works Councils. Reviewing the Directive", in Ian Fitzgerald; John Stirling (2004) (orgs.), European Works Councils. Pessimism of the intellect, optimism of the will?. Londres: Routledge, 67-79.

BushaCK, Willy (1999a), "Five years after: a look forward to the revision of the EWC Directive", Transfer - European Review of Labour and Research, 5 (3), 384-392.

BusHack, Willy (1999b), "Workers' involvement in the European Union or what happened to the Nautilus and Captain Nemo?", in E. Gabaglio e R. Hoffmann (org.), European Trade Union Yearbook, 1998. Bruxelas: European Trade Union Institute, 49-65.

BusHack, Willy (2000), "Review of the EWC Directive", in E. Gabaglio e R. Hoffmann (orgs.), European Trade Union Yearbook, 1999. Bruxelas: European Trade Union Institute, 161-172.

BusHack, Willy (2002), "Negotiating worker involvement in the European Company", in E. Gabaglio e R. Hoffmann (orgs.), European Trade Union Yearbook, 2001. Bruxelas: European Trade Union Institute, 189-203. 
CARLEY, Mark (2001), Bargaining at European level? Joint texts negotiated by European Works Councils. Dublin: European Foundation for the Improvement of Living and Working Conditions.

CARley, Mark; Marginson, Paul (2000), Comités d'entreprise européens: une etude comparative entre les accords vises à l'article 6 et à l'article 13. Luxembourg: Offices des publications officielles des Communautés européennes.

CEE do Grupo BES (2008), Boletim Informativo, outubro. Lisboa: Banco Espírito Santo.

CEE do Grupo BES (2009), Boletim Informativo, março. Lisboa: Banco Espírito Santo.

CEE do Grupo BES (2010a), Boletim Informativo, janeiro. Lisboa: Banco Espírito Santo.

CEE do Grupo BES (2010b), Relatório das visitas efetuadas aos balcões de Espanha (3 a 7 de maio de 2010) (policopiado).

CHOrA, António (2008), "A lei VW e a actual crise" (http://www.setubalnarede.pt/)

ClARCK, Nick; BAMFORD, Sean (2002), "Relationship between EWC members, with the workforce, and with the trade unions", in CCOO, Alpha Conseil, FNVformaat e TUC (orgs.), European Works Councils - Cases of good practice. Bruxelas: European Commission, 27-36.

Costa, Hermes Augusto (1996), Os Conselhos de Empresa Europeus: na rota da fábrica global? Lisboa: Fundação Friedrich Ebert.

Costa, Hermes Augusto (2004a), "Portuguese trade unionism vis-à-vis the European Works Councils", South European Society \& Politics, 9 (2), Autumn 2004 , 218-252.

Costa, Hermes Augusto (2004b), "O sindicalismo português face aos Conselhos de Empresa Europeus", em Boaventura S. Santos (org.), Trabalhar o mundo: os caminhos do novo internacionalismo operário, Porto, Afrontamento, 173-206.

CosTA, Hermes Augusto (2004c), "Saving jobs, protecting rights: the Autoeuropa Agreement", Transfer - European Review of Labour and Research, 10 (1), 123-125. Costa, Hermes Augusto (2005), Sindicalismo global ou metáfora adiada? Os discursos e as práticas transnacionais da CGTP e da CUT. (Tese de Doutoramento em Sociologia). Coimbra: Faculdade de Economia, 854 pp.

CostA, Hermes Augusto (2006), "Portuguese trade unionism vis-à-vis the European Works Councils", in B. S Santos e J. A. Nunes (orgs.), Reinventing democracy: grassroots movements in Portugal, Londres: Routledge, 218-252.

CosTA, Hermes Augusto (2008a), "O e-sindicalismo: recurso de luta sindical ou fait divers virtual?", Ensino Superior, 28, 42-45.

Costa, Hermes Augusto (2008b), Sindicalismo global ou metáfora adiada? Discursos e práticas transnacionais da CGTP e da CUT. Porto: Afrontamento, 347 pp. 
CostA, Hermes Augusto (2009a), "Modalidades de cooperação laboral transnacional: obstáculos e oportunidades para o sindicalismo ibérico”, in A. A. Buiza e E. J. M. Pérez (orgs.), Relaciones laborales y acción sindical transfronteriza. Granada: Editorial Comares, 193-229.

Costa, Hermes Augusto (2009b), "The impacts of European Works Councils in Portugal”, in ESA (org.), Full papers, 9th Conference of the European Sociological Association - European Society or European Societies? (Research Network 17, Industrial Relations, Labour Market Institutions and Employment) Lisboa: ISCTE/IUL, 1-20 [edição em CD-Rom]

Costa, Hermes Augusto (2009c), "A flexigurança em Portugal: desafios e dilemas da sua aplicação”, Revista Crítica de Ciências Sociais, 86, 123-144.

Costa, Hermes Augusto (2010), “Austeridade europeia, protesto europeu: o valor das manifestações transnacionais”, Le Monde Diplomatique (edição portuguesa), setembro, 24.

Costa, Hermes Augusto (2011), "A responsabilidade social das empresas em Conselhos de Empresa Europeus: missão impossível ou compromisso inevitável?”, in M. A. N. Costa; M. J. Santos; F. M. Seabra; F. Jorge (orgs.), Responsabilidade social: uma visão ibero-americana. Coimbra: Almedina, 259-293.

CostA, Hermes Augusto (2012a), "Flexigurança", in Centro de Estudos Sociais (org.), Dicionário das crises e das alternativas. Coimbra: Almedina, 105-106.

Costa, Hermes Augusto (2012b), "From Europe as a model to Europe as austerity: the impact of the crisis on Portuguese trade unions", Transfer-European Review of Labour and Research, 18 (4), 397-410.

CosTA, Hermes Augusto (2013), "European Works Councils between formal requirements and good practices: the potential for further developments based on evidence from the Portuguese case", Transfer - European Review of Labour and Research, 19 (4), 553-567.

Costa, Hermes Augusto; AraúJo, Pedro (2007a), "Diálogo social transnacional em multinacionais com sede em Portugal: Conselhos de Empresa Europeus, obstáculos e realizações", Sociedade e Trabalbo, 31, 17-32.

Costa, Hermes Augusto; Araújo, Pedro (2007b) Os Conselbos de Empresa Europeus: entre a responsabilidade social da empresa e a participação laboral. Relatório Final de Projeto de Investigação financiado pela Fundação para a Ciência a Tecnologia (POCI/SOC/59689/2004). Coimbra: Centro de Estudos Sociais, 587 pp.

Costa, Hermes Augusto; ARAúJo, Pedro (2007c), "Informação e consulta nas multinacionais: a experiência de representantes portugueses em Conselhos de Empresa Europeus", Revista Crítica de Ciências Sociais, 79, 3-33. 
Costa, Hermes Augusto; Araújo, Pedro (2008), "European Companies without European Works Councils: Evidence from Portugal”, European Journal of Industrial Relations, 14 (3), 309-325.

Costa, Hermes Augusto; AraúJo, Pedro (2009), As vozes do trabalho nas multinacionais: o impacto dos Conselhos de Empresa Europeus em Portugal. Coimbra: Almedina/CES, 223 pp. [Prémio Agostinho Roseta, 6. ${ }^{a}$ edição, 2011]

Costa, Hermes Augusto; Costa, Paula Reis (2011), Informação e consulta de trabalhadores nas multinacionais: análise do impacto dos Conselhos de Empresa Europeus em Portugal nos sectores metalúrgico, químico e financeiro (proj. III/7/2008). Relatório Final de Projeto de Investigação Financiado pelo Instituto de Investigação Interdisciplinar da Universidade de Coimbra. Coimbra: Instituto de Investigação Interdisciplinar da Universidade de Coimbra, 344 pp. [Menção honrosa - Prémio Manuel Lopes, 7. ${ }^{\text {e }}$ edição/2013]

Cristina, Sílvia Domingos (2009), A Vida de um Conselho De Empresa Europeu: Que Práticas e Expectativas? (Tese de Mestrado em Ciências do Trabalho e Relações Laborais). Lisboa: ISCTE.

Crystal, David (1997), English as a Global Language. Cambridge: Cambridge University Press.

DA Costa, Isabel; RehfeldT, Udo (2007), "European Works Councils and transnational bargaining about restructuring in the auto industry", Transfer-European Review of Labour and Research, 13 (2), 313-316.

Danis, Jean-Jacques; HoffmanN, Reiner (1995), "From the Vredeling Directive to the European Works Council Directive", Transfer-European Review of Labour and Research, 1 (2), 180-187.

DANIS, Jean-Jacques (1996), "European Works Councils", in Gabaglio e Hoffmann (orgs.) (1996), European Trade Union Yearbook. Bruxelas: European Trade Union Institute, 77-94.

DiDRY, Claude et al. (2005), "La construction et les enjeux d'un système de relations professionnelles européen”, in Groupe de projet Thomas (2005), L'Europe et le Dialogue Social. Recueil de notes, 12, 29-44.

Diretiva 2009/38/CE (2009), Jornal Oficial da União Europeia $n{ }^{\circ}$ L 122/128, de 16/05/2009, p. 122-128.

Diretiva 94/45/CE (1994), Jornal Oficial das Comunidades Europeias n. ${ }^{\circ}$ L 254 de 30/09/1994 p. 0064 - 0072.

DøLVIK, Jon Erick (2010), "The first test of the Maastricht social protocol. European Works Councils”, in Filip Dorssement and Thomas Blanke (orgs.), The Recast of the European Works Council Directive. Antuérpia: Intersentia, 91-104.

Dorssement, Filip; Blanke, Thomas (orgs.) (2010), The Recast of the European Works Council Directive. Antuérpia: Intersentia. 
EIRR (2000), “A survey of EWC members”, European Industrial Relations Review, 318, July 2000, 26-28.

EMCEF (2010), Emergency motion: Discussion Document from the Presidium to the General Assembly on a Future European Industry Federation of Trade Unions. Paris: EMCEF.

EMF et al. (2009), 2009/38/EC. The new EWC Directive: Recommendations on negotiations during the transposition period (5 June 2009 to 5 June 2011). Bruxelas: Social Development Agency/Information and Observatory Point (INFOPOINT).

ETUC (1999), "Review of the Directive on European Works Councils. Resolution adopted by the Executive Committee on 2/3 December 1999" (http://www. etuc.org/Exec/Resolutions/English/120299_ewc.cfm), acedido em 3.11.2000.

ETUC (2001), "The EWC-Directive needs urgently to be revised: amendments of the ETUC to the Directive" (http://www.etuc.org/EN/Dossiers/EWC/com 9445. cfm), 1-27, acedido em 5.02.2002.

ETUC (2010), On the offensive por more and stronger European Works Councils. The new European Works Council Directive ('recast'). Bruxelas: European Trade Union Confederation.

ETUC, UNICE/UEAPME, CEEP (2005), Lessons learned on European Works Councils. Relatório conjunto. http://www.ebr-service.de. Acedido em 25.07.2007. Eurofound (2008), European Works Councils in practice: key research findings (http://www.eurofound.europa.eu/pubdocs/2008/28/en/1/ef0828en.pdf). Dublin: European Foundation for the Improvement of Living and Working Conditions. European Journal of Industrial Relations (2000), 6 (1). Londres: Sage.

European Works Councils Bulletin (vários números). LexisNexis, Reino Unido/ Warwick Industrial Relations Ltd.

European Works Councils Database (2009) (http://www.ewcdb.eu/)

European Works Councils Database (2010) (http://www.ewcdb.eu/)

European Works Councils Database (2011) (http://www.ewcdb.eu/)

European Works Councils Database (2012) (http://www.ewcdb.eu/)

European Works Councils Database (2013) (http://www.ewcdb.eu/)

FERreIra, Virgínia (org.) (2010), A igualdade de mulberes e homens no trabalbo e no emprego em Portugal - politicas e circunstâncias. Lisboa: Comissão para a Igualdade no Trabalho e no Emprego.

FETZER, Thomas (2008), "European Works Councils as Risk Communities: The Case of General Motors”, European Journal of Industrial Relations, 14 (3), 289-308. FitzGERALD, Ian (2004), "Employee participation in Europe", in I. Fitzgerald e J. Sterling (orgs.), European Works Councils: Pessimism of the intellect, optimism of the will? Londres: Routledge, 1-11. 
Fitzgerald, Ian; STERling, John (2004) (orgs.), European Works Councils: pessimism of the intellect, optimism of the will? Londres: Routledge.

Freeman, R.B. (2005) 'The Advent of Open-source Unionism', Critical Perspectives on International Business 1 (2), 79-92.

GASPAR, Laura; FIOlHAIS, Rui (1996), Europa Social (1957-1992): evolução e perspectivas na área das relações e condições de trabalbo. Lisboa: Ministério para a Qualificação e o Emprego.

Gilman, Mark; Marginson, Paul (2004), "Negotiating European Works Councils. Contours of constrained choice", in Ian Fitzgerald \& John Stirling (eds.), European Works Councils. Pessimism of the intellect, optimism of the will?. London: Routledge, 93-112.

GoLD, Michael (2007) "The European Works Councils Directive. Changing rationals for EU regulation of employee participation" in Whittall, Knudsen, Huijgen. (orgs.), Towards a European Labour Identity - The case of the European Work Council. Londres: Routledge, 19-40.

Gomes, Pereira (2008), "Uma mensagem de esperança”, in CEE do GBES Boletim Informativo, outubro. Lisboa: Banco Espírito Santo.

Gomes, Pereira (2009), "Conselhos de Empresa Europeus: una nova realidade", in CEE do GBES Boletim Informativo, março. Lisboa: Banco Espírito Santo.

Grupo Banco Espírito Santo (2003), Acordo final para a instituição de um procedimento de informação e consulta no Grupo Banco Espírito Santo. Lisboa: Banco Espírito Santo.

Grupo Banco Espírito Santo (2008), Projeto de Acordo. Lisboa: Banco Espírito Santo.

HALL, Mark (2003), "Unions seek more influence for EWCs", International Union Rights, 10 (1), 6-7.

HANCKÉ, Bob (2000), "European Works Councils and industrial restructuring in the European motor industry", European Journal of Industrial relations, 6(1), 35-59.

Hertwig, Markus; Pries, Ludger; Rampeltshammer, Luitpold (2009), "European Works Councils as international non-profit-organisations: an organisational research approach to a crucial element of Europeanisation”, in M. Hertwig, L. Pries e L. Rampeltshammer (orgs.), European Works Councils in complementary perspectives. Bruxelas: European Trade Union Institute, 13-46.

Hertwig, Markus; Pries, Ludger; RAmpeltshammer, Luitpold (orgs.) (2009), European Works Councils in complementary perspectives. Bruxelas: European Trade Union Institute.

Hoffman, Reiner (2008), "EWCs seeking justice: assessment of the legal instruments to improve effectiveness of EWCs and grant full employment of workers' fundamental rights to information and consultation", in M. Monaco e C. Weis (orgs.), Infopoint 2008 EWC Workshops: beyond the directive, towards effective 
rights for EWCs. Bruxelas: Social Development Agency/European Trade Union Confederation, 10-14.

HoffmanN, Jürgen (2002), "Beyond the myth: 'international solidarity' as a challenge to trade unions in the age of globalisation and europeanisation", in J. Hoffmann (org.), The solidarity dilemma: globalisation, europeanisation and the trade unions. Bruxelas: European Trade Union Institute, 119-144.

Hoffmann, Reiner et al. (2002), The Europeanisation of industrial relations in a global perspective: a literature review. Luxemburgo. Foundation for the Improvement of Living and Working Conditions.

HyMAN, Richard (2001), "European integration and industrial relations: a case of variable geometry ?", in P. Waterman e J. Wills (orgs.), Place, space and the new labour internationalisms. Oxford: Blackwell, 164-179.

ICTU (Irish Congress of Trade Unions) (2006), Corporate social responsibility. A guide for trade unionists, Dublin, 1-48.

International Unions Rights (2011), Focus on global framework agreements, 18 (2). JAGODZINSKI, Romuald (2009), "Review, revision or recast? The quest for an amended EWC Directive”, in European Trade Union Institute and Observatoire Social Européen (orgs), Social developments in the European Union 2008. Bruxelas: European Trade Union Institute, 113-135.

Jornal Oficial da União Europeia (2009), Diretiva 2009/38/CE do Parlamento Europeu e do Conselho de 6.05.2009. JOUE n. ${ }^{\circ}$ L 122/28-122/44, de 16 de maio de 2009.

Jornal Oficial das Comunidades Europeias (1994), Diretiva 94/45/CE do Conselho de 22.09.1994. JOCE n. ${ }^{\circ}$ L 254/64-254/72, de 30 de setembro de 1994.

KercKHOFs, Peter (2000), "European works councils developments in 1999", in E. Gabaglio e R. Hoffmann (orgs.), European Trade Union Yearbook, 1999. Bruxelas: European Trade Union Institute, 133-160.

KERCKHOFs, Peter (2002), European Works Councils: facts and figures. Bruxelas: European Trade Union Institute.

Kerckhofs, Peter (2006), European Works Councils - Facts and figures. Bruxelas: European Trade Union Institute for Research, Education and Health and Safety.

KERCKHOFS, Peter (2010), "Can the recast Directive bring more and more effective EWCs?", in Filip Dorssement and Thomas Blanke (orgs.), The Recast of the European Works Council Directive. Antuérpia: Intersentia, 399-419.

KerckHofs, Peter; Pas, Irmgard (2006), European Works Councils Database. Inventory of companies affected by EWC Directive, Bruxelas, European Trade Union Institute, for Research, Education and Health and Safety. 
KovÁcs, Ilona; LOPEs, Margarida Chagas (2012), "A juventude e o emprego: entre a flexibilidade e a precariedade", in S. F. Casaca (org.), Mudanças laborais $e$ relações de género: novos vetores de (des)igualdade. Coimbra: Almedina, 51-86.

KNUdSEN, Herman (1995), Employee participation in Europe. Londres: Sage.

Kotтhoff, Herman (2007), "The European Works Council and the feeling of interdependence", in M. Whittall, H. Knuden e F. Huijgen (orgs.), Towards a European Labour Identity. The case of European Works Councils. Londres: Routledge, 168-181.

LAMERs, Josee J. M. (2010), "EWC's role recast: A European actor?”, in Filip Dorssement and Thomas Blanke (orgs.), The Recast of the European Works Council Directive. Antuérpia: Intersentia, 357-397.

LE Douaron, Jean-Claude (2008), "Training: an indispensable tool for European Works Councils representatives", in M. Monaco e C. Weis (orgs.), Infopoint 2008 EWC Workshops: beyond the directive, towards effective rights for EWCs. Bruxelas: Social Development Agency/European Trade Union Confederation, 57-60.

LECHER, Wolfgang (1999), "Resources of the European Works Council - empirical knowledge and prospects", Transfer - European Review of Labour and Research, 5 (3), 278-301.

LeCher, Wolfgang; Platzer, Hans-wolfgang; RüB, Stefan; WeINER, Klaus-Peter (1999), The establishment of European Works Councils: from information committee to social ator. Aldershot: Ashgate.

LECHER, Wolfgang; PlATZER, Hans-wolfgang; RÜB, Stefan; WeINER, Klaus-Peter (2001), European Works Councils: developments, types and networking. Aldershot: Gower. Lecher, Wolfgang; Platzer, Hans-wolfgang; RüB, Stefan; WeIner, Klaus-Peter (2002), European Works Councils: negotiated Europeanism. Between statutory framework and social dynamics. Aldershot: Ashgate.

LEE, Eric (2000), The Internet belongs to every one (http://www.labourstart.org/ icann/ericleebook.shtml)

LEE, Eric (2004), "Towards global networked unions”, in R. Munck (org.), Labour and globalisation: results and prospects. Liverpool: Liverpool University Press, 71-82.

LEE, Eric (2006), "Online campaigns and the wisdom of crowds", International Union Rights, 13 (3), 17.

Leite, Jorge; Fernandes, Liberal; Amado, Leal; ReIs, João (1996), Conselhos de Empresa Europeus: comentários à Diretiva 94/45/CE. Lisboa: Cosmos.

LuCiO, Miguel Martínez; Weston, Syd (2000), "European Works Councils and 'flexible regulation': The politics of intervention", European Journal of Industrial Relations, 6(2), 203-216. 
MARginson, Paul (1992), "European integration and transnational management-union relations in the enterprise", British Journal of Industrial Relations, 30 (4), 529-545. Marginson, Paul (1994), "The eclecticism of managerial policy towards labour regulation”, Warwick Papers in Industrial Relations, 47.

MARGINSON, Paul (1999), "EWC agreements under review: arrangements in companies based in four countries compared", Transfer - European Review of Labour and Research, 5 (3), 256-277.

MARginson, Paul (2000), "The Eurocompany and Euro industrial relations", European Journal of Industrial Relations, 6 (1), 9-34.

MARginson, Paul et al. (2004), "The impact of European Works Councils on managment decision-making in UK and US-based multinationals: a case study comparison", British Journal of Industrial Relations, 42 (2), 209-233.

Marginson, Paul; Gilman, Mark; Jacobi, Otto; Krieger, Hubert (1998), Negotiating European Works Councils: an analysis of agreements under article 13. Report for the European Foundation for the Improvement of Living and Working Conditions and the European Commission. Luxemburgo: Office for Official Publications of the European Communities.

Marginson, Paul; Lavelle, Jonathan; Quintanilla, Javier; Mangas, Rocío Sanchez (2009), Transnational Employee Voice in Multinational Companies: variable dialogue in European Works Councils. Paper apresentado no MNCs Symposium, IIRA World Congress, Sydney (mimeo)

MARginson, Paul; SIsson, Keith (1996), "European Works Councils - opening the door to European bargaining?”, Industrial Relations, 3 (3), 229-236.

MARginson, Paul; SISSON, Keith (2004), European integration and industrial relations. Basingstoke: Palgrave.

MILlER, Doug (1999), "Towards a "European" works council”, Transfer - European Review of Labour and Research, 5 (3), 344-365.

Miller, Doug; Stirling, John (1998), "European Works Council Training: An opportunity Missed?", European Journal of Industrial Relations, 4 (1), 35-56.

Miller, Doug et al. (2000), "The politics of language and European Works Councils: Towards a research agenda”, European Journal of Industrial Relations, 6 (3), 307-323.

MonACO, Marina (2007), Gender related issues: good practices within European Works Councils 2007. Bruxelas: Social Development Agency/European Trade Union Confederation.

Monaco, Marina; WeIs, Christian (orgs.) (2008), Infopoint 2008 EWC Workshops: beyond the directive, towards effective rights for EWCs. Bruxelas: Social Development Agency/European Trade Union Confederation. 
Moreau, Marie-Ange (2006), "Restructuration et comité d'entreprise européen", EUI Working Paper LAW, 02.

Moscovici, Serge; DoIse, Willem (1991), Dissensões e Consenso. Lisboa: Livros Horizonte.

Müller, T; Hoffman, A (2001), "EWC research: a review of literature" (http://www. users.wbs.warwick.ac.uc/irru/publications/conference_papers.htm)

NAKANO, Satochi (1999), "Management views of European Works Councils: A preliminary survey of Japanese multinationals", European Journal of Industrial Relations, 5(3), 307-326.

NAmuTH, Michaela (2005), "European and Supportive", Mitbestimmung International Edition (http://www.boeckler.de/cps/rde/xchg/SID-3D0AB75D-F851138A/ hbs/hs.xsl/164_37796.html).

OCDE (2011), Les principles directeurs de L'OCDE à l'intention des entreprises multinationales: recommandations pour une conduite responsable des entreprises dans le contexte international (http://www.oecd.org/dataoecd/43/30/48004355. pdf) . Paris. OCDE.

PATERnotre, Michel (1998), “La Directive «Comité d'Entreprise Européen». État des lieux avant révision”, Observatoire Social Européen, Working Paper, 21 (http:// www.ose.be/old/fr/publications/detail.htm), acedido em 7.10.2005.

Perlmutter, H. (1969), "The tortuos evolution of the multinational corporation", Columbia Journal of World Bussiness (janeiro/fevereiro), 9-18.

PICARD, Séverine (2010), European Works Councils: a trade union guide to Directive 2009/38/EC (report 114). Bruxelas: European Trade Union Institute.

Platzer, Hans-Wolfgang (2009), "Approaching and theorising European Works Councils: comments on the emergence of a European multi-level-structure of employee involvement and participation", in M.Hertwig, L. Pries e L.Rampeltshammer (orgs.), European Works Councils in complementary perspectives. Bruxelas: European Trade Union Institute, 47-69.

PUlignANO, Valeria (2007) "Co-ordinating across borders - The role of European industry federations with European Works Councils” in Whittall, Knudsen, Huijgen. (orgs.), Towards a European labour identity - The case of the European Works Council. Londres: Routledge, 74-93.

RAMSAY, H. (1997), "Fool's Gold? European Works Councils and workplace democracy", Industrial Relations Journal, 28(4), 314-322.

REHFELDT, Udo (1993), "Les syndicats européens face à la transnationalisation des enteprises", Le Mouvement Social, 162, 69-93.

REIBSCH, Reinhard (1998), "Eficacia y significado de los comités de empresas europeos", in M. S. Castro e A. Wachendorfer (orgs.), Sindicalismo y globalización: la dolorosa inserción en un mundo incierto. Caracas: Nueva Sociedad, 107-130. 
ReIS, José; BAgAnHA, Maria Ioannis (2001) 'Introdução', in J. Reis e M. I. Baganha (orgs.), A Economia em Curso: Contextos e mobilidades, Porto: Afrontamento, 13-32.

SA (s/d) "Informações de fundo sobre a Lei VW", (http://www.oskovo.cz/Ext/ VW/vwp_07por.pdf).

SANTOS, Boaventura de Sousa (1995), Toward a new common sense: law, science and politics in the paradigmatic transition. Londres: Routledge.

SANTOS, Boaventura de Sousa (1997), "Por uma concepção multicultural dos direitos humanos”, Revista Crítica de Ciências Sociais, 48, 11-32.

SANTOS, Boaventura de Sousa (2001), "Os processos da globalização", in B. S. Santos (org.), Globalização: fatalidade ou utopia? Porto: Afrontamento, 31-106.

Schömann, Isabelle (2004), Corporate Social Responsibility, Threat or opportunity for the social dialogue?, in European Trade Union Yearbook, 2003/2004. Bruxelas: European Trade Union Institute, 137-155.

Schömann, Isabelle; Sobzack, André; Voss, Eckhard; Wilke, Peter (2008), "International framework agreements: new paths to workers' participation in multinationals' governance?", Transfer - European Review of Labour and Research, 14 (1), 111-126.

SILVA, Armindo (2008), “As diretivas europeias na esfera do trabalho", Janus 11, 204-205.

Simões, Nuno (1996), "Informação e Consulta dos Trabalhadores nas Empresas ou Grupos de Empresas de Dimensão Comunitária: Um modelo negocial”. Lisboa: Conselho Económico e Social, 7-55.

Social Development Agency (2009), (http://www.sda-asbl.org/)

Social Development Agency (2010), (http://www.sda-asbl.org/)

Social Development Agency (2011), (http://www.sda-asbl.org/)

Social Development Agency (2012), (http://www.sda-asbl.org/)

Social Development Agency (2013), (http://www.sda-asbl.org/)

SPEIDEL, Frederic (2012), "The 'Volkswagen Law' - guarantor of extended co-determination rigths and international trade union solidarity", Transfer-European Review of Labour and Research, 18 (4), 497-501.

STANZANI, Claudio (2008), "Summary of the conclusions of the EWC workshop", in M. Monaco e C. Weis (orgs.), Infopoint 2008 EWC Workshops: beyond the directive, towards effective rights for EWCs. Bruxelas: Social Development Agency/European Trade Union Confederation, 61-65.

STEIERT, Robert (2001), "European Works Councils, World Works Councils and the liaison role of the trade unions: a test of international union policy”, Transfer - European Review of Labour and Research, 7 (1), 114-131. 
STEIERT, Robert; UhL, Hans-Jürgen; BRÜNING, Magdalena (2002), "A social charter for Volkswagen: a new milestone in industrial relations”, Transfer-European Review of Labour and Research, 8 (4), 711-714.

STEVIS, Dimitris (2010), "International framework agreements and global social dialogue: Parameters and prospects”, Employment Working Paper, 47. Geneve: ILO, 1-33.

STIRLING, John; Fitzgerald, Ian (2001), "European Works Councils: Representing workers on the periphery", Employee Relations, 23(1), 13-25.

STIRling, John; Tully, Barbara (2004), "Power, process, and practice: communications in European Works Councils”, European Journal of Industrial Relations, 10 (1), 73-89.

STOор, Sjef (2002), "Relations with management", in CCOO, Alpha Conseil, FNVformaat e TUC (orgs.), European Works Councils - Cases of good practice. Bruxelas: European Commission, 13-26.

STREECK, Wolfgang (1997), "Neither European nor Works Councils: a reply to Paul Knutsen”, Economic abd Industrial Democracy, 18, 325-327.

STREECK, Wolfgang (1998), "The internationalization of industrial relations in Europe: Prospects and problems”, Politics \& Society, 26 (4), 429-459.

Teles, Patrícia Galvão; Albuquerque, Catarina (2008), "Multinacionais e direitos humanos na era da globalização", Janus, 11, 206-207.

Telujohann, Volker (2005a), "The European Works Councils - a role beyond the EC Directive?", Transfer - European Review of Labour and Research, 1 (5), 81-96. Telljohann, Volker (org.) (2005b), Quality inventories on the operation and results of European Works Councils. Bolonha: Fondazione Istituto per il Lavoro.

Telujohann, Volker (2007), "Interest representantion and European identity - A twofold challenge for European Works Councils", in M.Whittall, H. Knudsen e F. Huijgen. (orgs.), Towards a European Labour Identity - The case of the European Work Council. Londres: Routledge, 150-168.

Teljohann, Volker (org.) (2005), Quality inventories on the operation and results of European Works Councils. Bolonha: Fondazione Istituto per il Lavoro.

Teldjohann, Volker, Costa, Isabel da; Müller, Torsten; Rehfeldt, Udo; Zimmer, Reingard (2009), "European and international framework agreements: new tools of transnational industrial relations", Transfer - European Review of Labour and Research, 15 (3-4), 505-525.

Timming, Andrew R; Veersma, Ulke (2007) "Living apart together? A Chorus of multiple identities" in Whittall, Knudsen, Huijgen. (orgs.), Towards a European Labour Identity - The case of the European Work Council. Londres: Routledge, 41-54. 
Transfer - European Review of Labour and Reseach (1995), Vol. 1 (2). Bruxelas: European Trade Union Institute.

Transfer - European Review of Labour and Reseach (1999), Vol. 5 (3). Bruxelas: European Trade Union Institute.

Tully, Barbara (2004), "Organising across borders. Developing trade union networks", in Ian Fitzgerald; John Stirling (2004) (orgs.), European Works Councils. Pessimism of the intellect, optimism of the will?. Londres: Routledge, 165-177.

VALLEJO, Carlos; White, Robin (2002), "Company restructurings", in CCOO, Alpha Conseil, FNVformaat e TUC (orgs.), European Works Councils - Cases of good practice. Bruxelas: European Commission 37-48.

VITOLS, Sigurt (2003), "Management cultures in Europe: European Works Councils and Human Resource management in multinational enterprises", Final Report of a study commissioned by the Forum Mitbestimmung und Unternebmen. A joint initiative of the Bertelsmann Foundation and the Hans Böckler Foundation. (http://www.wz-berlin.de.), acedido em 03.10.2007.

VITOLS, Sigurt (2009), "European Works Councils: an assessment of their social welfare impact", Working paper 2009.04. Bruxelas: European Trade Union Institute.

VW AG; Comissão de Trabalhadores do Grupo Mundial VW; FITIM (2002), Declaração sobre direitos sociais e relações industriais na Volkswagen. Bratislava. 6.06.2002 (mimeo) (http://www.imfmetal.org/files/Sozialcharta_por.pdf)

VW AG; CT Europeia do Grupo VW; CT Mundial do Grupo VW; FITIM (2009), Carta das relações laborais no Grupo Volkswagen. Zwickau, 29.10.2009, 1-7 (mimeo).

WADDington, Jeremy (2002), "Views on the agenda of European Works Councils and on the revision of the directive: a perspective from five countries", in E. Gabaglio e R. Hoffmann (orgs.), European Trade Union Yearbook, 2001. Bruxelas: European Trade Union Institute, 173-188.

WADDINGTON, Jeremy (2003), "What do representatives think of the practices of the European Works Councils? Views from six countries", European Journal of Industrial Relations, 9 (3), 303-325.

WADDINGTON, Jeremy (2006a), "How EWC members see it", Mitbestimmung International Edition, 8, 41-44.

WADDINGTON, Jeremy (2006b), "The views of European Works Councils representatives", Conference Co-determination in a Modern Europe: Democratic Workers' Participation or Convergence at Minimal Standards, organized by the Otto Brenner Stifung, Bratislava, May 30-Jun 1.

WADDINGTON, Jeremy (2006c), "The performance of EWCs 12 years after the Directive", European Works Councils Bulletin, 65, September/October, 7-11. 
WADDINGTON, Jeremy (2011), European Works Councils: a transnational industrial relations Institution in the making. Londres: Routledge.

WAdDington, Jeremy; KercKhofs, Peter (2003), "European Works Councils: what is the current state of play?", Transfer - European Review of Labour and Research, 9 (2), 322-339.

Waterman, Peter (2004), "Internacionalismo sindical na era de Seattle", in E. Estanque, L. M. Silva, R. Véras, A. C. Ferreira e H. A. Costa (orgs.), Relações laborais e sindicalismo em mudança: Portugal, Brasil e o contexto transnacional. Coimbra: Quarteto, 209-246.

Weber, Tina et al. (2000), "Costs and benefits of the European Works Councils Directive”, Employment Relations Research Series, N. 9.

WeBster, Edward; LAMBERT, Rob (2004), "Emancipação social e novo internacionalismo operário: uma perspectiva do Sul", in B. S. Santos (org.), Trabalhar o mundo: os caminhos do novo internacionalismo operário. Porto: Afrontamento, 65-111.

WeILER, Annie (2004), European Works Councils in practice. Report for the European Foundation for the Improvement of Living and Working Conditions and the European Commission. Luxemburgo: Office for Official Publications of the European Communities.

Weston, Syd e Lucio, Miguel Martinez (1997), "Trade unions, management and European Works Councils: Opening Pandora's box?", The International Journal of Human Resource Management, 8 (6), 764-779.

Whittall, Michael; Knuden, Herman; Hujugen, Fred (2009), "European Works Councils: Identity and the Role of Information and Communication Technology”, European Journal of Industrial Relations, 15 (2), 167-185.

WhitTall, Michael; Knuden, Herman; Huijgen, Fred (orgs.) (2007), Towards a European Labour Identity. The case of European Works Councils. Londres: Routledge. Wills, Jane (1998), "Making the best of it? Managerial attitudes towards, and experience of, European Works Councils in UK-owned multinational firms", Working Paper N. ${ }^{\circ}$, Southampton: Department of Geography, University of Southampton.

WILls, Jane (2000), "Great expectations: three years in the life of a European Works Council”, European Journal of Industrial Relations, 6 (1), 83-105.

Wills, Jane (2001), "Uneven geographies of capital and labour: the lessons of European Works Councils”, in P. Waterman e J. Wills (orgs.), Place, space and the new labour internationalisms. Oxford: Blackwell, 180-205.

Wills, Jane (2004), "Re-scaling trade unions organizations: Lessons from the European front line", in Ronaldo Munck (org.), Labour and Globalisation. Liverpool: Liverpool University Press, 85-104. 
(Página deixada propositadamente em branco) 
Série Investigação

Imprensa da Universidade de Coimbra

Coimbra University Press

2014

- $\mathbf{U}$

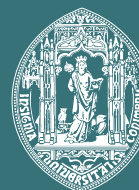

C •

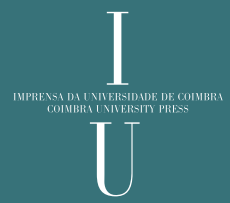

